
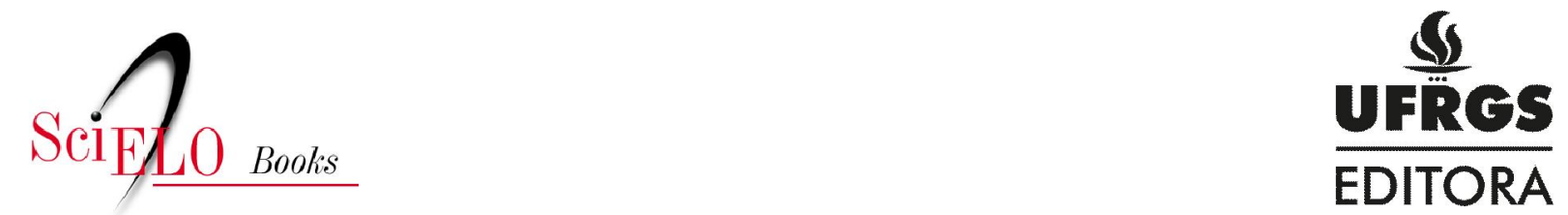

\title{
Espacialidade e exacerbação do corpo
}

\author{
Paulo Silveira
}

SciELO Books / SciELO Livros / SciELO Libros

SILVEIRA, P. Espacialidade e exacerbação do corpo. In: A página violada: da ternura à injúria na construção do livro de artista [online]. 2nd ed. Porto Alegre: Editora da UFRGS, 2008, pp. 120-245. ISBN 978-85-386-0390-0. Available from doi: 10.7476/9788538603900. Also available in ePUB from: http://books.scielo.org/id/2pwn4/epub/silveira-9788538603900.epub.

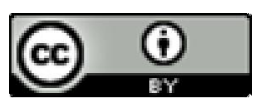

All the contents of this work, except where otherwise noted, is licensed under a Creative Commons Attribution 4.0 International license.

Todo o conteúdo deste trabalho, exceto quando houver ressalva, é publicado sob a licença Creative Commons Atribição 4.0.

Todo el contenido de esta obra, excepto donde se indique lo contrario, está bajo licencia de la licencia $\underline{\text { Creative Commons }}$ $\underline{\text { Reconocimento } 4.0 .}$. 


\section{Espacialidade e exacerbação do corpo}

\section{O livro como corpo físico}

Entre as declarações publicadas na revista nova-iorquina Art-Rite, dedicada aos livros de artista, edição do inverno de 1976 para 1977, existe uma que me é especialmente simpática. "Um artista que se senta para examinar seu próprio livro sente o movimento do ar contra seu rosto enquanto vira as páginas" (p.13, definição de John Shaw). Essa satisfação nascida da completude e do contato remete ao que de mais determinante ou distintivo tem o livro de artista: sua fisicalidade. Como todo livro (aqui entendido como o volume), ele também é um corpo físico que ocupa lugar no espaço. É uma coisa, um objeto. Mas se o livro é, o livro de artista é muito mais. É linguagem e metalinguagem tornadas concretas. É um corpo físico expressivo.

Corpo é "todo objeto material que ocupa um espaço e tem por principais propriedades: a extensão em três dimensões, a impenetrabilidade e a massa" (Japiassú e Marcondes, 1990). Por essa condição ele "possui propriedades sensíveis [...] ou que causam nos seres humanos [...] impressões, ou estímulos, ou ambas as coisas” (Mora, 1996). Podemos direcionar esse entendimento, adjetivando-o. Pelo ponto de vista que o considera a matéria orgânica que forma (conforma) o homem, é o "corpo humano". Nesse caso ele é qualificado porque encerra a alma, ou o psíquico, ou a mente. A dependência dos conceitos está por detrás da metáfora histórica que atribui conteúdo anímico aos livros, frequentemente representado da pintura antiga até os produtos culturais e de entretenimento de massa do século 20. Da mesma forma, a sugestão do rosto humano ou fantástico está presente tanto em encadernações verdadeiras como nas representadas em alegorias, em contos de fadas e nas mais diversas fantasias.

É sempre necessário voltar aos conceitos expostos no início. Pergunta: a interdependência explícita do livro de artista com um objeto já consagrado que é o seu referente formal pode ser determinante de sua condição de gênero artístico especial? Tim Guest 
(1981, p.9 e 19) nota que os livros de artista são todos, sobretudo, livros. Como ele está se referindo ao sentido estrito - o fruto de um movimento iniciado nos anos 60 -, suas considerações estreitam ainda mais essa relação.

Com esses qualificadores em mente, e reconhecendo a grande diversidade de conteúdo nos livros de artistas, o que determina esse conjunto de obras de arte como um gênero específico? A resposta óbvia é que todos eles são livros - conscientemente e manifestamente de si mesmos; mas além disso, livros, como qualquer outra forma de arte, conotam e prestam-se para certas coisas. Para descrever essas conotações e para ter por considerar a função dos livros de artistas, existem (ao menos) quatro eixos temáticos aos quais o leitor pode recorrer:

1) a estrutura formal e conotações da forma de livro.

2) a função documental do livro.

3) o livro como forma de arte distributiva.

4) a realização da sensação de leitura.

A partir daqui, sobretudo o primeiro e quarto eixos serão estudados, talvez os mais passíveis de intervenções físicas. O segundo eixo foi estudado anteriormente, e o terceiro será comentado apenas eventualmente, já que interessa pouco para este trabalho.

O problema tropológico (uso de sentido figurado) que incide no conceito do livro não existe na prática. É usual que se aceite a realidade unificadora da palavra "livro". Mas no esforço de um desenvolvimento crítico, deve-se lembrar, novamente, que de fato a substância física que o compõe é o antigo volumen, a unidade material, termo originado dos rolos precursores. O liber latino era a unidade intelectual contida neles: liber est interior tunica corticis, ou o livro é a túnica (o revestimento) interior da proteção (do córtex). Ou melhor, a proteção como a trama de papiro em rolo, revestida na face interna pela escrita. A evolução da forma, sua reprodutibilidade, a expansão da literatura, a vulgarização do ensino e da contabilidade, o desenvolvimento das ciências, etc., propiciaram a fusão dos conceitos. Hoje não mais importa que o volume contenha o livro. Ou será que importa?

Será que o livro é um corpo que contém alma, metaforicamente falando? Essa dúvida, como outras (valor, significado social, originalidade, etc.), é acompanhada de problemas dialéticos que são o próprio retrato de um caldo de tensões. São tensões que comportam dualidades, ambiguidades e controvérsias que possivelmente não seriam aprofundadas sem o entorno conceitual que forjou o conceito "livro de artista" em sua primeira acepção, antes da sua atual (quase) vulgarização. Germano Celant insere o fenômeno na continuidade das experiências plásticas (e talvez políticas) do pós-guerra. Ele acusa a tensão dialética interna ao "informal" (aspas dele) nos anos 1956-1963, quando a ênfase ao elemento natural e ao humano se transfere para o relacionamento entre o homem e a mídia. A mídia seria usada não como um meio, mas como um fim em si mesmo. Nesse período poderiam ser identificados dois grupos de aproximação ao meio. No primeiro, o aspecto físico da obra tendia a ser subserviente aos seus elementos humanísticos. No segundo, o aspecto físico era apresentado como parte intrínseca da 
essência primária e complexidade orgânica da obra. Um meio significante em si mesmo nos seus usos cotidianos e não-artísticos (Guest e Celant, 1981, p.85-86).

O livro é um objeto no sentido genérico, uma coisa que pode ser apreendida pela percepção ou pelo pensamento. Sendo material e ocupando um lugar no espaço, tem nas três dimensões a principal característica de ser um corpo físico matemático. Como corpo, portanto, possui a propriedade de causar impressões e estímulos nos seres humanos. Os dualismos corpo e alma, corpo e espírito, corpo e mente e outros semelhantes importam aqui de uma maneira acessória. Neste enfoque, o corpo é sensível e inteligível, através da relação entre o plano material e o plano mental e dessa possível identidade, pelo uso da leitura e/ou da percepção como ferramenta de compreensão ou apreensão.

É pela percepção mais ou menos imediata (por vezes reflexa) da aparência que o livro que é obra de arte se instaura, mesmo naqueles que são bastante discretos. A leitura, o desfrute e a intelecção são processos de aproximação posterior. Para qualquer das etapas, é principalmente a sua eloquência como corpo físico que impõe o seu status de objeto artístico. Oscila entre o belo e o espalhafatoso, entre o livre e o imobilizado, entre a preservação da forma e a perversão de sua finalidade e função. Do deleite ao estranhamento, passando por suas possíveis gradações, até talvez a uma possível repulsa, é a eloquência da (ou pela) fisicalidade que institui a sua identidade. Eloquência porque é capaz de comunicação em grau complexo e marcante, seja de modelo visual, ou verbal, ou ambos. Eloquência, também, por portar mensagem, ou por ser (por sua própria compleição física) texto, fazendo da audiência e suas circunstâncias o contexto.

Uma diferença a ser destacada entre o artista gráfico, que profissionalmente cumpre expediente em uma editora, e o artista plástico, que experimenta o livro de artista em suas formas mais livres, está no tipo de Doutor Frankenstein que cada um é. O primeiro constrói corpos - sempre. Não é de sua "função" desconstruí-los. A uma alma dada, desgarrada, ele dá o corpo, elaborado com a originalidade possível a sua profissão. Serão cotejados princípios já aceitos com novas soluções entrando na moda. Alguma ousadia poderá haver em seu trabalho, mas apenas com a tolerância das partes envolvidas. A individualização do criador afluirá com extrema dificuldade. Seu livro buscará ser, por princípio e norma, apolíneo. Veja-se, como rápido exemplo, um preceito de Douglas C. McMurtrie (1982, p.595):

À pergunta "qual é o melhor tipo para todos os fins, desenhado desde o começo da imprensa até agora?", não pode dar-se resposta duvidosa. O tipo foi desenhado e gravado por William Caslon e pode aplicar-se anos e anos para todos os fins sem enfadar o gosto. [...] O tipo Caslon é também o melhor tipo para livros que se tem fabricado, pois é legível no mais alto grau e não se torna monótono.

Este é um exemplo de proposição de norma estética. Ela tem sido confirmada por especialistas e editores. E um exemplo de aceitação dessa norma é este texto que está 
sendo lido, respeitosamente composto em Caslon Old Face, a partir de uma tipologia desenvolvida na oficina de Caslon, em Londres, por volta de 1725 (Glaister, 1996, p.86).

$\mathrm{O}$ artista plástico do livro constrói corpos - mas nem sempre. Ele tem a liberdade para construir o novo ou desconstruir o já existente. Esse é o seu esperado papel social. Ele funda a alma de sua obra a partir de sua própria individualidade ou de uma persona hipotética. Ou de qualquer concepção possível. O corpo será elaborado com a liberdade que a técnica e a tecnologia permitirem. Sua criatura é livre para ser apolínea ou dionisíaca.

\section{As artes do livro e a identidade do livro artístico}

Ao menos na minha rua, caso se pergunte a um artista visual o que são as artes gráficas, ele prontamente responderá: a gravura e suas técnicas, litogravura, xilogravura, gravura em metal, serigrafia, etc. Se a mesma pergunta for feita a um projetista industrial, ele de imediato responderá: a impressão e suas técnicas, o offset, a rotogravura, a tipografia, a flexografia, etc. Por transitar na fronteira do mundo das artes com o mundo da editoração, posso testemunhar que o et cetera de um são as técnicas do outro. Na interseção entre essas realidades parece estar um dos atormentados espaços e limites do livro de artista.

Tome-se como exemplo Escritura (1973), publicado por Gastão de Holanda através da editora que ele compartilhava com Cecília Jucá, no Rio de Janeiro. Gisela Creni, 1992, conta a experiência como infeliz.

Nessa obra, prefaciada pelo editor, a ilustração de cada caderno foi entregue a pintoras e gravadoras como Renina Katz, Vera Bocayuva Mindlin e Anna Bella Geiger, que se inspiraram em fragmentos de prosa de diversos escritores. Apesar da ousadia conceitual (ou até mesmo por causa dela), o livro foi mal recebido pelos meios gráficos e bibliófilos, o que abalou as finanças da editora no dia do lançamento, com 300 pessoas, quando só um exemplar foi vendido.

Existe uma eventual, e talvez por isso muito diplomática, incompatibilidade de gênios envolvida nesse problema. $\mathrm{O}$ livro de artista (ou, nesse momento, o livro de arte, como é frequentemente chamado por alguns bibliófilos) tem sua expansão no mercado de bens culturais imbricada com tensões de identidade. Ele tem muito da arte, outro tanto da bibliotecnia, fortes elementos da comunicação visual e do projeto industrial, apropriações literárias, um pouco de gramática cinematográfica, algumas intenções políticas e quase quantos et ceteras se puder imaginar.

Já foi observado, ao estudarmos a conceituação, que ele possui uma constituição mestiça. Melhor seria dizer: vira-lata. Ele se afirma (se institui) sobre o que o precede, anexando a sua conformação tudo que for necessário para sua expressão, importando pouco

\footnotetext{
* Nota de editoração. Trata-se da tipologia usada no original de 1999 e em duas edições. Para compatibilidade simultânea em sistemas gráficos e digitais em 2016, foi substituída por Adobe Caslon Pro.
} 
a origem. Quanto ao livro que já existe, está muito bem estabelecido, através de séculos de experiência e método com suas próprias doutrinas. É para estudar a materialidade do livro convencional que existe uma disciplina, a bibliotecnia, do grego biblion, livro, e tekne, arte. É justo e correto que a utilizemos como ferramenta adicional à critica artística na compreensão do livro de artista contemporâneo, especialmente do livro-objeto. Ela é o estudo das "artes do livro" (com aspas).

Chama-se arte do livro (ou artes do livro) ao conjunto de atividades envolvidas em sua produção, seja ele industrial ou artesanal. Exclui-se dessas atividades a criação literária ou textual. Do projeto gráfico à impressão final, podem ser arroladas muitas faturas - intelectuais, manuais ou industriais - com a participação da arte pura e aplicada, do artesanato e da tecnologia: projeto gráfico ou programação visual, composição, paginação, ilustração, fotografia, impressão do miolo, impressão de anexos ou encartes, impressão de capa e sobrecapa, encadernação e outras atividades subalternas ou não às citadas. Embora hoje, com altíssimo grau de presença da computação, ainda persistam princípios consagrados. Alguns desses elementos podem ainda se ramificar em muitas especializações. A associação desses elementos ao trabalho de texto (revisão, tradução, copidescagem, retranca, etc.) constitui a editoração, uma atividade profissional, especializada a partir da interdisciplinaridade entre letras, comunicação e artes, tão antiga quanto a sua história. Modernamente se subdivide em edição de arte e edição de texto.

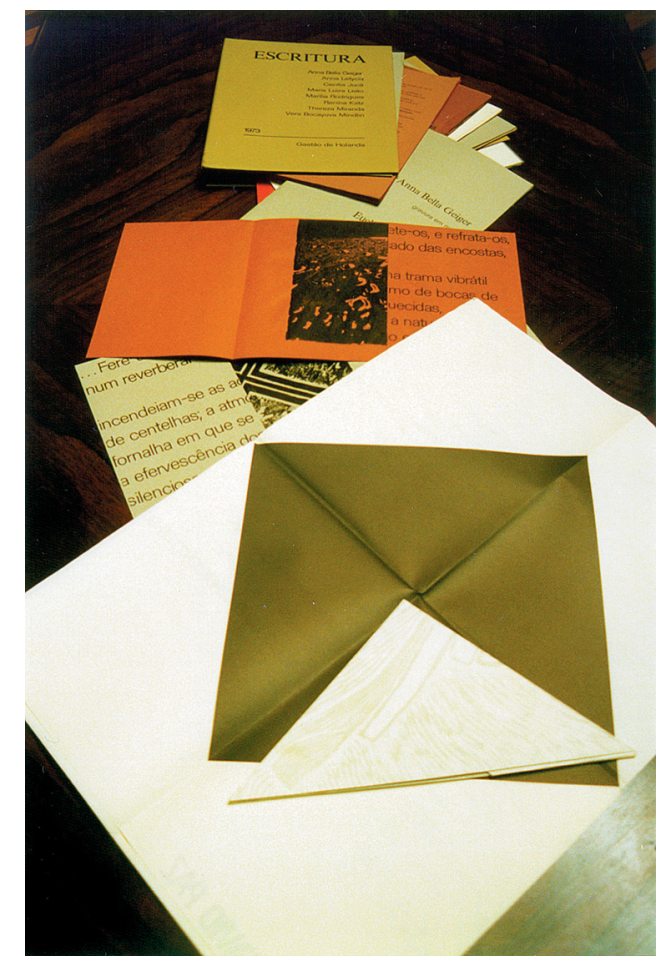

Gastão de Holanda, organizador, Escritura, 1973.

Participação de Anna Bella Geiger (gravura em metal; texto de Euclides da Cunha), Anna Letycia (serigrafia; texto de Aníbal Machado), Cecília Jucá (tipografia; texto de Vassili Kandinski). Maria Luiza Leão (serigrafia; texto de Gastão de Holanda), Marília Rodrigues (xilogravura; texto de Octavio Paz), Renina Katz (serigrafia; texto de Victor Vasarely), Thereza Miranda (gravura em metal; texto de Manuel Bandeira), e Vera Bocayuva Mindlin (xilogravura; texto de Carlos Drummond de Andrade). Acervo da Biblioteca Nacional, Rio de Janeiro.

A bibliografia disponível sobre bibliologia e bibliotecnia privilegia o estudo quase exclusivo do consagrado, do tido como belo, e que pode, de alguma forma, atender a premissas estéticas. Se são premissas, então possuem um dominante comportamento conservador. 
Em bibliologia quase não há lugar para vanguardas. Talvez isso ocorra por preferir, como as ciências em geral, um objeto de análise que pare quieto no lugar. De modo geral, livros sobre livros não falam em livros de artista ou livros-objetos. Em $A$ construção do livro, por exemplo, Emanuel Araújo ignora o fenômeno do livro de artista contemporâneo. Não é aceitável que isso aconteça, pouco importando se a arte deveria ou não assumir sozinha a resenha do fenômeno. Mesmo quando da primeira tiragem da primeira edição, em 1986, já haviam ocorrido algumas importantes mostras no Brasil, algumas delas retrospectivas. Por outro lado, ele passa perto do assunto quando ao discorrer sobre a iconografia do livro cita uma entrevista para o Jornal do Brasil concedida por Riva Castleman em 1981 (Araújo, 1986, p.531). Pode-se argumentar que essa omissão se justificaria pela desatenção brasileira pela interpenetração das mídias. Mas existem outros exemplos à disposição. A Encyclopedia of the book, do britânico Geoffrey Ashall Glaister (1917-1985), é um clássico da bibliologia, publicado em Londres, em 1960 (primeira edição) e 1979 (segunda edição revisada e ampliada), e reimpresso em $1996 .{ }^{19}$ Completíssimo, o volume no entanto não registra verbetes como artist's book ou book-object. Apenas livres de peintres pode ser encontrado, ainda que a segunda edição tenha sido acrescida de 1.144 entradas inteiramente novas. Existem livros tão ou mais importantes que esses, elaborados antes ou depois deles, que também não reconhecem essa especificidade artística (alguns títulos podem ser encontrados na segunda parte da "Bibliografia"). As obras citadas não o foram com qualquer sugestão de demérito; ao contrário, são trabalhos riquíssimos, obrigatórios a quem quer que esteja interessado no assunto, quer pelos padrões brasileiros, quer pelos internacionais. Além disso, mesmo na bibliografia de artes visuais existem omissões onde menos se espera: por exemplo, no grande The dictionary of art, obra inglesa de muitos volumes (Grove/Macmillan Publishers, 1996).

Alguma coisa impede uma maior consideração pelo livro de artista contemporâneo, ou pelo livro-objeto (quando gráfico), pela bibliologia. Como conhecimento interdisciplinar que tem sua sustentação em descrições de aparência, ela poderia cuidar de ser menos estetizante e mais atenta ao atual. E em particular aos problemas da arte que interferem diretamente tanto no fazer livros quanto na determinação de novas funções a eles. Mesmo um grande nome da bibliofilia como José Mindlin, provavelmente o maior colecionador de livros raros do País, costuma deixar transparecer um apego conservador nas divertidas conferências que dá. É o que pode também ser percebido em suas colaborações para os catálogos Brasil: sinais de arte (1993) e Livro-objeto: a fronteira dos vazios (1994), que são basicamente um mesmo texto, diplomaticamente alterado nos agradecimentos e em alguns outros detalhes, já que também uma exposição era de fato o prosseguimento da outra.

No centro dessas constatações está a denominação um pouco tola "arte (ou artes) do livro". Não consegui determinar em que momento histórico preciso, na bibliologia, a palavra "arte", nesse caso, agregou à original concepção de mister a sua aura estetizante

\footnotetext{
${ }^{19}$ Também foi feita uma edição norte-americana em 1960 e uma reimpressão da segunda edição em 1996, também norte-americana, unificando a distribuição ao mercado de língua inglesa.
} 
e valorativa característica. Observe-se a definição dada pelo Novo dicionário Aurélio da língua portuguesa (já citado) que representa algo próximo do senso comum.

arte [...]. Arte do livro. Parte das artes gráficas que, compreendendo a judiciosa escolha de papéis e tintas, a tipografia, a ilustração e a encadernação, tem por fim a harmoniosa integração, no livro, de sua dupla função de objeto de estudo e de objeto de arte.

Note-se os adjetivos "judiciosa" e "harmoniosa”, uma presença prescritiva frequente em enfoques externos às artes. É, por isso, necessário transferir o ponto de vista para dentro da arte, procurando buscar o que corresponde à realidade do fato artístico de especulação intelectual a que pertence o livro de artista como objeto com identidade visual e conceitual (ainda que essa identidade própria não seja incontestável para alguns). Uma descrição tão simples quanto adequada pode ser encontrada em Print collecting, de Silvie Turner, professora no Royal College of Art, em Londres (cito sua atividade para marcar seu comprometimento intelectual).

A arte do livro é concebida e elaborada por um artista e pode tomar diversas formas, variando do integralmente visual ao exclusivamente textual. A arte do livro é frequentemente publicada pelos próprios artistas; o conteúdo frequentemente inclui poesia, imagens, filosofia, autobiografia, narrativa, texto político, até documentação de performances, e assim por diante.

A arte do livro emprega numerosas técnicas manuais ou mecanizadas de impressão e pode também incluir originais - aquarelas, fotografias, desenhos, etc. É publicada em impressão única, tiragens limitadas ou abrangendo de poucas centenas a edições ilimitadas. (Turner, 1996, p.59)

Percebe-se aqui a evidência do papel do conhecimento artístico contemporâneo aplicado na descrição singela de um conceito, o revitalizando. Isso não é acidental.Turner também é autora, além de obras no campo da gravura, de Facing depage: British artists'books, 1993. Aqui o artista tem responsabilidade total, da forma e do conteúdo. Ou do conteúdo se transmutando em forma, ou vice-versa. Ou seja, a plasmação gerando a materialização da linguagem, ou o corpo abrigando uma hipotética alma, numa entidade una.

Um esclarecimento complementar pode ser obtido de Gary Frost, influente "encadernador" norte-americano, mestre em artes pelo Art Institute of Chicago e professor na University of Texas. Possui, por isso, uma compreensão universalista que me interessa neste estudo. Ele explica "como os livros funcionam".

[...] É interessante e perturbador que tão importante ferramenta cultural possa ser usada tão inconscientemente. $\mathrm{O}$ manuseio hábil de livros começa com alguma consideração dos seus mecanismos de mobilidade. [...]

É um fato curioso que as mãos tenham induzido a mente. Nós agora imaginamos que a destreza evoluiu com nosso cérebro, mas o registro fóssil hominídeo mostra de outra maneira. Alta destreza e anatomia da mão evoluíram nas espécies hominídeas mais primitivas antes do aumento do tamanho do cérebro. A evidência anatômica também indica que a feitura de ferramentas precedeu a linguagem. A cultura originada da investigação manual do mundo natural e as aptidões da destreza despertaram a mente. 
O primeiro traço característico da comunicação permanece conosco. O livro tem sua escala física para permitir o virar de páginas e nós examinamos o livro com as mãos antes de examinar o seu conteúdo. As aptidões da destreza ajudam a explicar o paradoxo pelo qual nós transmitimos obras conceituais via mídia física. Predecessores dos livros como as notações paleolíticas incisas em ossos, símbolos de contabilidade do mesolítico ou o quipo literário inca exemplificam objetos ágeis e talismânicos que também são mídia de conteúdo conceitual. A convergência de mídia física para transmitir obras conceituais talvez reflita uma velha dependência da manipulação de objetos físicos para auxiliar e confirmar a conceitualização. (Frost, 1997)

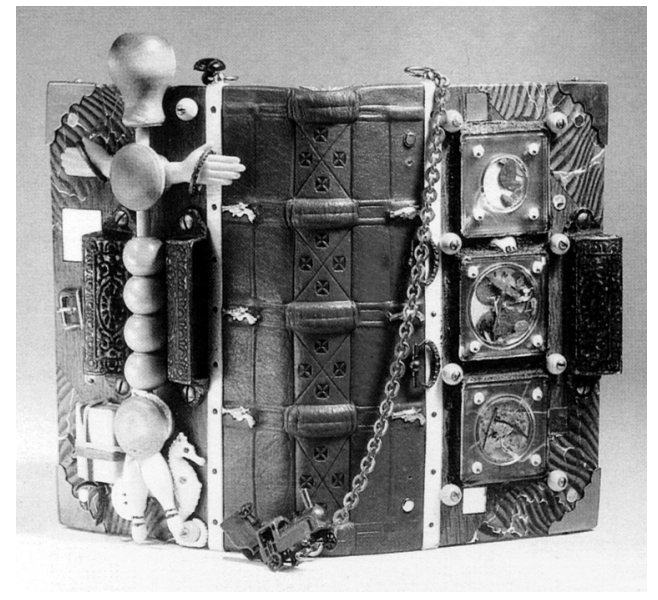

Gary Frost, The tracts of Moses David, 1978

(Frost, 1997).

$\mathrm{Na}$ língua portuguesa, arte do livro é uma designação de uso mais ou menos comum muito antes das vanguardas da arte em livro. Note-se sua presença em alguns dos dicionários e livros de referência citados no decorrer desta pesquisa. Já estava no prefácio da edição de 1937 de O livro, de Douglas C. McMurtrie (1888-1944), em que, entre outros agradecimentos, ele citava o Museu de Arte Moderna de Nova York que "teve a gentileza de emprestar as chapas das ilustrações de livros de alguns eminentes pintores e escultores modernos"(McMurtrie, 1982, p.4). ${ }^{20}$ São reproduções de Giorgio de Chirico (para Calligrames, de Apollinaire, 1930), Pablo Picasso (para Metamorfoses, de Ovídio, 1932) e Henri Matisse (para Poemas, de Mallarmé, 1932). O senso de contemporaneidade de McMurtrie era invejável.

O livro de artista não é servil a um escritor. Ele é a obra de um artista. Nessa condição, ele apresenta mistérios específicos que dificultam a sua presença em obras gerais. Mas ele já possui uma "gramática" básica, uma certa institucionalização, uma fuga do underground. Já existem alguns "livros de receitas", alguns manuais de como fazer, que são especialmente voltados à produção pós-conceitual. Ou seja, àquelas obras com participação artesanal do artista, frequentemente em peças únicas.

É marcante a série de publicações de Keith A. Smith. O autor é artista do livro e tem sua própria editora e distribuidora, a keith a smith $B O O K S$ (sic). Smith produz livros de artista e livros sobre livros. O segundo grupo é composto por brochuras comuns, com capa e miolo em preto-e-branco, a preços de mercado. Podem ser comprados acabados ou em folhas soltas "para aqueles que desejam encadernar a mão as suas próprias cópias". A obra mais famosa é Structure of the visual book, seu livro número 95, com primeira edição de 1984, revista e ampliada em anos posteriores. Descreve problemas sintáticos

${ }^{20}$ Segunda edição portuguesa a partir da oitava reimpressão (1965); edição original de 1927: The Golden Book. 
e morfológicos dos principais procedimentos técnicos, ilustrados com obras de 55 artistas. Quase todos os nomes citados são norte-americanos com vínculos com o livro-objeto plástico ou gráfico-plástico. Entre os artistas de origem não anglófona, está a brasileira Lucila Machado Assumpção, com fotos de seu livro O fio, de 1990. É uma obra em sanfona com desenho em linha de costura através das páginas; com o livro fechado é possível ler nos dorsos "une", "consciência", "verso" e "subtil"; com ele aberto lê-se "meditando", recortado em uma letra por página.

A apresentação modesta, com acabamento "de máquina", aliada à necessária interação com o leitor, faz desses "livros sobre livros" um espaço de intercâmbio entre a indústria gráfica e a arte. As páginas em branco, os textos e os espaços autocomentando-se, a necessidade de recortar e dobrar as páginas (especialmente em Text in book format, também já reeditado), e a possibilidade de experimentar encadernações pessoais (adquirindo os volumes em folhas

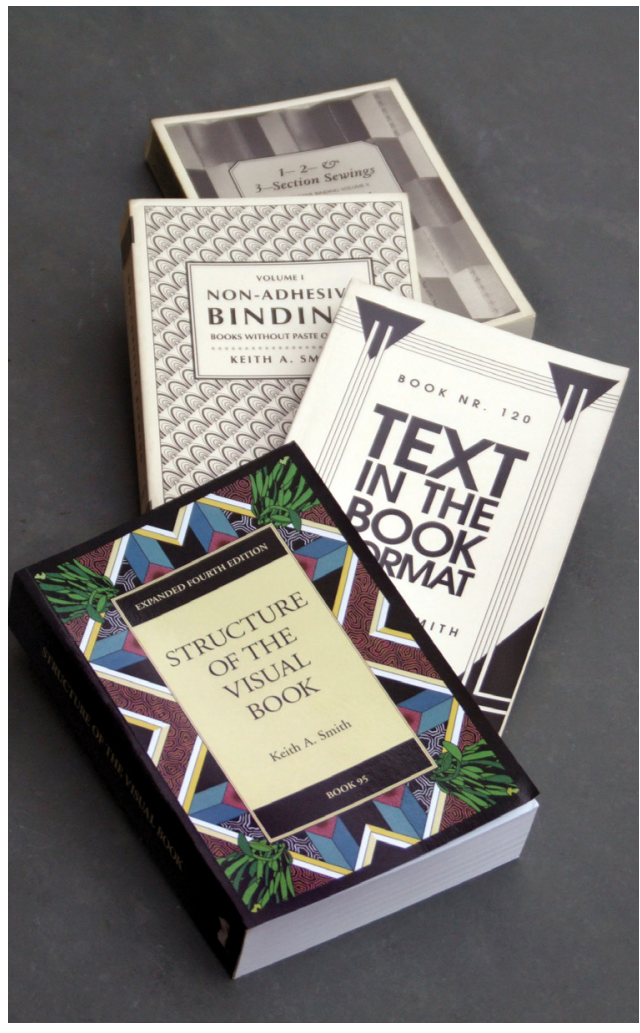

Keith Smith, livros sobre livros, publicados a partir de1984, alguns já reeditados. soltas, especialmente para a série Non-adhesive binding, em três tomos), impedem que as obras se comportem silenciosamente, como "corpos mortos" (qualificação usada certa vez por um professor em uma banca examinadora de pós-graduação, apontando problemas recorrentes nos livros especiais).

Parece que existem poucos manuais úteis, direcionados para a elaboração de livros-objetos. A maioria deve ser, de fato, sobre encadernação criativa, uma evolução da encadernação tradicional tornada possível graças às vanguardas dos anos 60 a 80 (considerando-se as precedentes, dos anos pré-guerras) e a uma relativa, às vezes contrariada, aceitação do livro-objeto. Além dos livros de Smith, há menção na "Bibliografia" de Lauf e Phillpot, 1988, do trabalho de Shareen LaPlantz, Cover to cover: creative techniques for making beautiful books, journals and albuns, 1995. Trata-se de um manual do tipo faça-você-mesmo, para grande público, que pretende proporcionar ao leitor livros feitos à mão que são certeza "de se tornar objeto de estima para você ou alguém de sua lista de presentes" (texto promocional da contracapa). Possivelmente ele abra mais portas para mal-entendidos e confirme uma "reartezanalização" pós-moderna do livro-objeto. LaPlantz reconhece ter acontecido "uma explosão nas artes do livro na última década". No entanto, usa book arts se referindo a "todo 
tipo de livros feitos à mão, incluindo livros em branco, reencadernações, álbuns, diários e livros de artistas". Segundo ela, "livros de artistas são aqueles que combinam estrutura (ou técnica), formato, imagens visuais e apresentação". Continua dizendo que "texto é opcional” (p.5, Introdução). Ela reduz todos os conceitos para a área de alcance de sua atividade, resumindo muito a realidade dos fatos. O seu público é certamente outro do que o de Smith. A pergunta que essas constatações geram é: será essa vulgarização do processo uma perversão sobre a multiplicação da obra? Penso que as vanguardas não acabaram, mas alguns de seus pressupostos já estão engolidos, digeridos e recolocados no mercado, para o bem ou para o mal. A publicação de LaPlantz certamente tem alguns exageros, em exemplos que talvez não passem de formalismos dispensáveis. De corpos sem alma. Mas a maior parcela de trabalhos reproduzidos é interessante, com
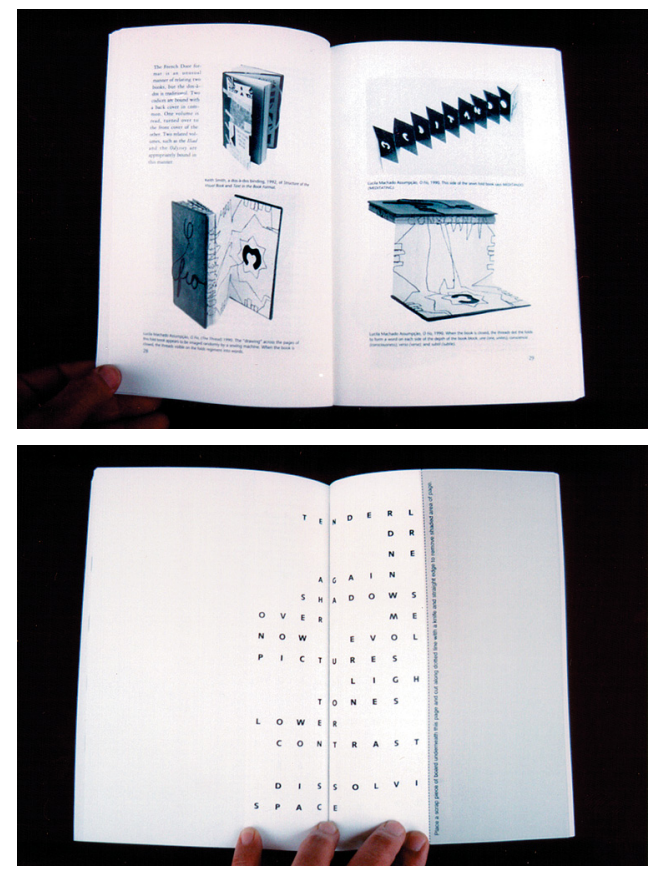

Keith Smith, livros sobre livros, 1984-1998.

No alto, Structure of the visual book (livro 95; edição de 1998), e embaixo, Text in book format (livro120; edição de 1995). qualidade e vigor. São, não tenho dúvida, exemplos de carinho extremado pelo livro, o que deve ser respeitado. $\mathrm{E}$ além disso, pode ser adquirido por apenas $\$ 16,95$ !

Movimentar-se rigorosamente pelo gosto regido pela regra pode impedir o interesse pela obra. Como é enfatizado por Drucker (1995, p.29), a propósito desse fato e do ensaio de William Morris, O livro ideal, muitas diretrizes têm servido para o livro de artista como parâmetros a serem inovados, bem como para desviar dos seus preceitos de decoro. Livros de artista, afinal, são distintos das edições de luxo "pela negligência ou pela violação - e às vezes ignorância - de tais regras". Mas, apesar de tudo, ou por causa disso, como notado por Stefan Klima (1998, p.7), os livros de artista se assentam "em algum lugar num canto remoto das artes do livro".

\section{Até pode ser que isso não seja um livro de artista. Mas e se for?}

A partir das considerações precedentes, podemos racionalizar o que já percebíamos intuitivamente. Quer seja um livre de peintre, quer seja um livro-objeto, o livro de artista lato (ou o livro-arte) se impõe como tal, primeira e definitivamente, como objeto visual e 
tátil que pode prescindir da comunicação literária. Então por que a primeira dificuldade de delimitação do campo ou categoria artística é a forma difusa em que seus limites se apresentam, por um lado com o livro industrial, e por outro com as categorias artísticas do objeto e da escultura? Isso acontece especialmente com a obra industrial, que, afinal, é configurada para a leitura linear.

Neste momento do texto é preciso atender a problemas talvez menos simpáticos, referentes à banalização industrial, demonstrados principalmente por construções ambíguas. O limite do livro de artista com a escultura deverá ficar mais claro adiante, quando será abordada a presença da desconstrução mais agressiva. Por hora, é preciso realçar a porosidade entre a arte, a indústria e o comércio, e a imprecisão de fronteiras nesse terreno que envolve o consumo cultural. Como para tanto serão necessários alguns comentários sobre obras que certamente não são, ou ainda não são, ou que às vezes quase são livros de artista, ou que capitalizem seus ensinamentos, sugiro que o leitor interessado em não pisar em terreno alagadiço passe direto para o seguimento posterior. Entretanto, aquele que prosseguir encontrará representantes autênticos indiscutíveis.

Tomei emprestada a ideia do título para esse seguimento de um capítulo de Anne Moeglin-Delcroix (1985), para realçar um problema que persiste nesse reino, no que diz respeito a seu imperecível relacionamento com a indústria gráfica e editorial de postura comercial. Moeglin-Delcroix puxou o assunto para lá, para a escultura. Vou puxar o problema para cá, para o mercado. Por isso, tentando ser breve, citarei primeiramente alguns "produtos" nacionais ao nosso alcance que assimilam conceitos artísticos livro-referentes. $\mathrm{Na}$ maior parte dos casos (mas não em todos), não são livros de artistas. Mas poderiam ser.

Existe uma alteração recente importante na intermediação entre o artista e a impressão final de seu trabalho, diferente do que acontece com os processos artesanais de gravura. Os registros demonstram que os artistas que não podiam ou não queriam, eles mesmos, operar equipamentos gráficos mecânicos industriais, utilizaram os serviços de um impressor (ou mestre-impressor) para concretizar os seus projetos. À figura do impressor cabia a montagem ou elaboração da matriz, assim como a execução dos trabalhos de entintamento e impressão. Com a afirmação e posterior consagração do impresso em offset, a indústria gráfica ganhou maior rapidez e precisão, além do barateamento de custos para reprodução de imagens em preto-e-branco e coloridas. Isso diminuiu a importância do impressor e aumentou a responsabilidade do profissional que faz a matriz e do que elabora o original de artes gráficas. Passou a ser necessário o trabalho de um arte-finalista, profissional que já foi recentemente incorporado pela figura do projetista gráfico, habilitado no uso da computação gráfica (editoração eletrônica), e com conhecimentos de percepção visual, frequentemente com formação universitária. Isso tudo dito, assim, muito resumidamente. Se o livro ilustrado, livre de peintre ou livre d'artiste, ficava atrelado ao fazer artesão, o livro de artista contemporâneo pode ser devedor ao fazer técnico. Especialmente nos anos 90, a plena difusão do uso do computador como ferramenta gráfica, disponibiliza o acesso ao acabamento profissional. Os processos 
são mais acessíveis e a fidelidade de cores é excelente. Pode-se dizer que é inútil, em alguns casos, perseverar na emulação de rusticidade. Tal qualidade pode fazer com que a obra se pareça com certos produtos industriais que se impõem nas prateleiras das livrarias convencionais da moda.

Duas publicações recentes chamam a atenção entre os títulos tradicionais. A primeira, Manchas, de Anésia Pacheco e Chaves, 1998, Terra Editora, São Paulo, pode ser facilmente encontrada. É uma brochura de qualidade e requinte industrial que não esconde essa condição. Tem sua diagramação apoiada no binômio imagem e palavra. Equilibra grafismos e tachismos com textos próprios. Se em Cadernos, de 1993, a artista insistia no valor da documentação através de esporádicas fotos de seus cadernos originais, agora ela assume o suporte industrial e o trabalho como um todo, como obra individual criada para o offset e vendida para um público amplificado.

A outra publicação é uma autoantologia de Tunga (Antônio José de Mello Mourão), Barroco de lírios, com a qual outra editora de livros de arte de luxo, a Cosac \& Naify, abriu as suas portas em 1997. Totalmente concebida por ele, a obra tem encartes e diferentes tipos e gramaturas de papel e impressão em oito cores, com a tiragem gigante para os padrões brasileiros de cinco mil exemplares. É "um autêntico livro de artista” (!), como chegou a ser citado em artigo da revista $I_{s-}$ to $\bar{E}$, de variedades (Comodo, 1998). Deve-se tomar isso por elogio? Observe-se a capa.
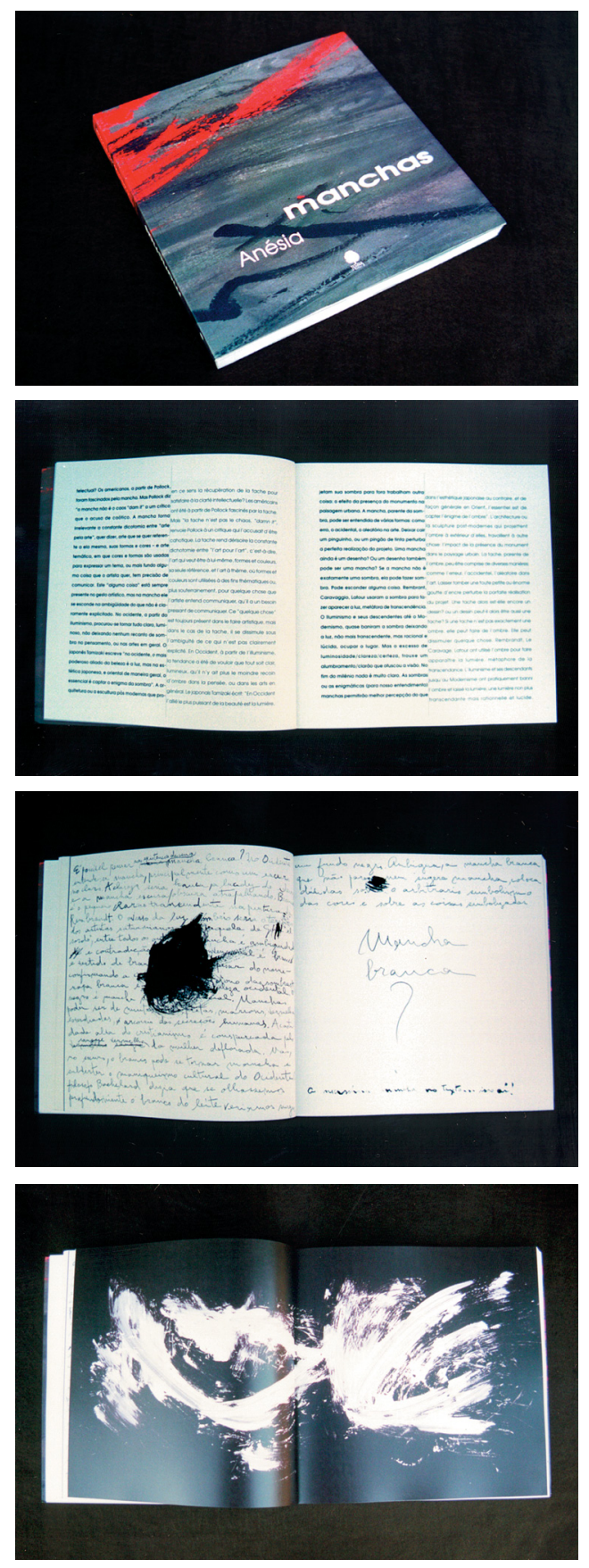

Anésia Pacheco e Chaves, Manchas, 1998. Quem se lembra do título, Barroco de lírios? O nome de Tunga está grafado com destaque. Tem tal tamanho que lembra um autor de best-seller. É uma solução gráfica previsível que provavelmente só teria lugar num objeto artístico se fosse uma ironia. Como está, é um indício de livro comercial. Ainda assim, por 
suas qualidades, fica a dúvida: é um livro de arte ou é um livro de artista?

Os blocos de texto de Manchas também têm um tempero formalista. Melhor dizer: fashion. Ainda assim sua identidade merece atenção. Tanto Anésia como Tunga contaram com editores ousados para os padrões brasileiros, que buscaram distribuição nacional e internacional. Em ambos os casos as gráficas eram de primeira linha. Mas dificilmente se realizariam sem o acompanhamento, em parte ou no todo, de um projetista gráfico (ou programador visual). Tunga e Anésia não são, absolutamente, estranhos ao livro de artista. Ambos participaram de muitas mostras, com obras em todos os graus de artesania. Mas são expoentes de seu tempo e utilizam, sem cerimônias, as ferramentas oferecidas pela tecnologia gráfica disponível. Seus livros recentes são livros-limite entre a arte e a indústria justamente por essa dimensão profissional. Mas observe-se que o trabalho técnico de arte-finalização esteve creditado mesmo em obras mais singelas, que não oferecem dúvidas quanto ao seu papel no desenvolvimento do livro de artista brasileiro, como em Armar, de Ronaldo Azeredo, 1977. Também Julio Plaza, um artista e pesquisador com identidade e força próprias, às vezes se apresentou somente como um auxiliar do projeto, como em $\mathrm{Ta}$ tuagens, de Edgard Braga, 1976. Os livros de Tunga e Anésia, além disso, são casos que tiveram alguns antecedentes importantes, de distribuição internacional ou nacional, com inserção na moderna mídia de massa. É o caso de The medium is the massage: an inventory of effects, 1967, de Marshall McLuhan e Quentin Fiore. Integrado na dinâmica de seu tempo cultural, pequeno, barato, era uma brochura popular com uma arrojada concepção gráfica em preto-e-branco (de Fiore) diretamente ligada ao entrecruzamento do pop com a estética de divulgação jornalística.
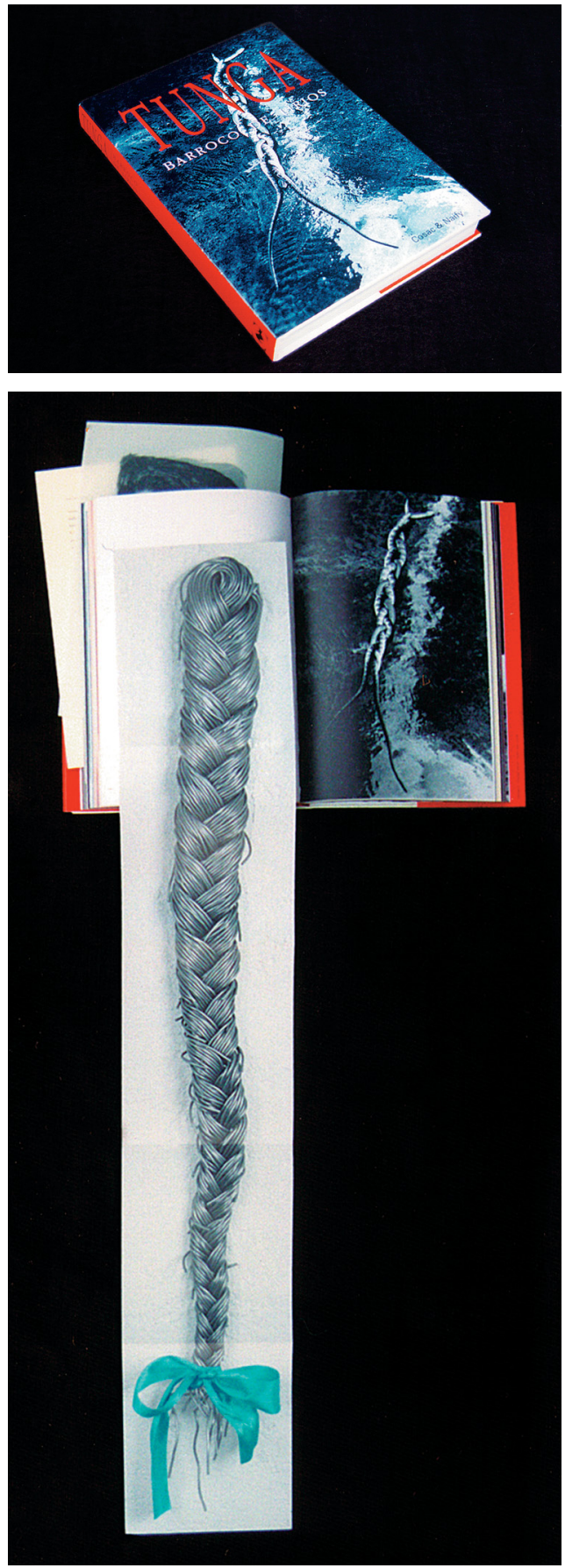

Tunga, Barroco de lírios, 1997. 
Foi um trabalho de colaboração que correu mundo, devedor das possibilidades de distribuição global. Rompia os limites do livro industrial ao se apresentar como leitura alternativa, apoiada na imagem. Uma diferença, entretanto, deve ficar clara. The medium and the massage custou para o consumidor pelo menos um quarto do preço de Manchas ou Barroco de lírios, o que é resultado, também, de ideologia.

Vigor gráfico parecido pôde ser encontrado no Brasil na série Arte Brasileira Contemporânea, editada pela Funarte (Fundação Nacional de Arte) nos anos 70 e 80, bem como em algumas edições autônomas que fugiram do tradicional. No caso da série da Funarte, popularizada como $A B C$, elas eram brochuras, impressas a cores em papel cuchê, com 40 a 60 páginas. Uma equipe de programação visual (com nomes cambiantes ${ }^{21}$ apoiava, a partir de um protótipo básico no formato $22,3 \times 18,0 \mathrm{~cm},{ }^{22}$ a elaboração de exemplares individualizados para e por cada artista. Os livros tinham como título o nome do artista. Como um adicional (um plus?, uma agregação de valor?), havia textos de convidados. A série foi composta por Barrio, 1978 (o único com apenas texto próprio), Carlos Vergara, 1978 (com texto de Hélio Oiticica), Anna Bella Geiger, 1978, impresso em março de 1979, segundo o colofão (com texto de Fernando Cocchiarale), Antonio Dias, 1979 (com texto de Paulo Sérgio Duarte), Wesley Duke Lee, 1980 (com texto de Cacilda Teixeira da Costa), Lygia Clark, 1980 (com textos de Ferreira Gullar e Mário Pedrosa), Cildo Meireles, 1981 (com texto de Ronaldo Brito), Manual da ciência popular, de Waltercio Caldas Jr.,

Marshall McLuhan e Quentin Fiore, The medium is the massage: an inventory of effects, 1967-1996.

\footnotetext{
${ }^{21}$ Na programação visual os nomes mais frequentes são de Sula Danowski, Vera Bernardes, Ana Monteleone e Noni Geiger. O projeto da coleção está creditado, em algumas edições, a Afonso Henriques Neto, Eudoro Augusto Macieira e Vera Bernardes.

${ }^{22}$ Dificilmente uma gráfica refila (corta) um livro no formato exato pretendido pela editora. Mesmo as melhor aparelhadas podem falhar. Portanto, o valor é aproximado. Há exemplares com 21,9 até $22,4 \mathrm{~cm}$ na altura. As larguras variam menos. Apenas pelas marcas de corte gravadas nos fotolitos é possível afirmar o tamanho projetado na arte-final.
}
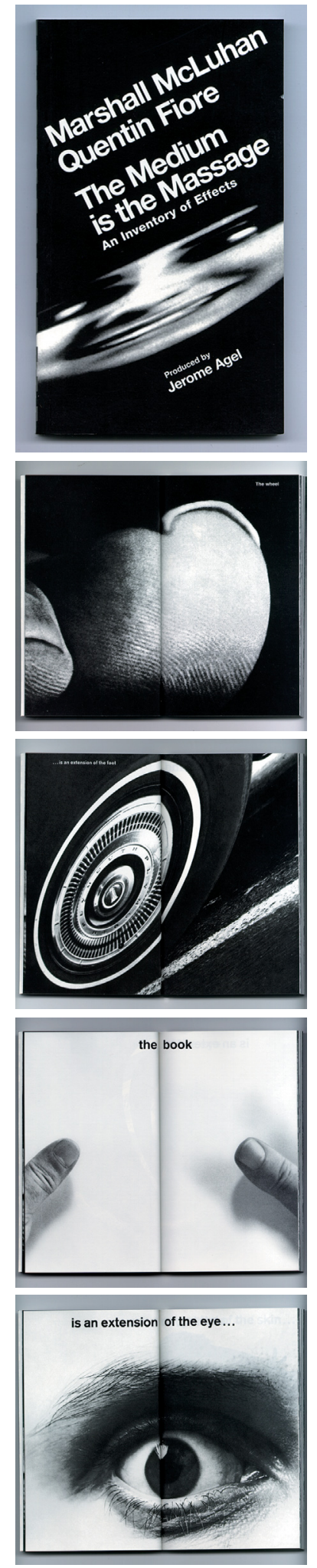
1982 (com texto de Paulo Venancio Filho), Lygia Pape, 1983 (com texto de Mário Pedrosa e poemas de Luiz Otávio Pimentel), e Antonio Manuel, 1984 (com textos de Frederico Morais, Hélio Oiticica, Mário Pedrosa e Ronaldo Brito). Esses livros também trouxeram consigo sua dose de desagrado, por sua localização ambígua nas prateleiras. Fabris e Costa, 1982, tornaram claro seu desconforto perante eles, o que deveria ser fruto de uma mirada no sentido da expectativa de uma obra informativa. Foi apontado o autoelogio dos artistas. Visto por outro ângulo, como obra de expressão, em artigo de 1988, Annateresa Fabris, individualmente, reconsidera esse entendimento. Ela reconhece que eles "explodem os limites convencionais entre 'informação' e 'ilustração"'. E destaca os títulos de Barrio, Waltercio Caldas Jr. e Lygia Pape.

Alguns dos livros possuem encartes ou recortes internos. O de Waltercio Caldas Jr. é o único com título individualizado. E, junto com o de Lygia Pape, possui capa em fundo branco, ao contrário do restante da série que possui capas em preto dominante. Os textos críticos, exegéticos ou apologéticos adicionais são fruto do interesse informativo e formativo da Funarte, talvez na procura de sucesso mercadológico. Mas a qualidade artística dos volumes prescinde deles: nesse caso podem até ser considerados desnecessários ou mesmo inconvenientes. Comportam-se voluntariamente como elementos legitimadores, pela palavra escrita, do pensamento criativo dos artistas. ${ }^{23}$ Inter-

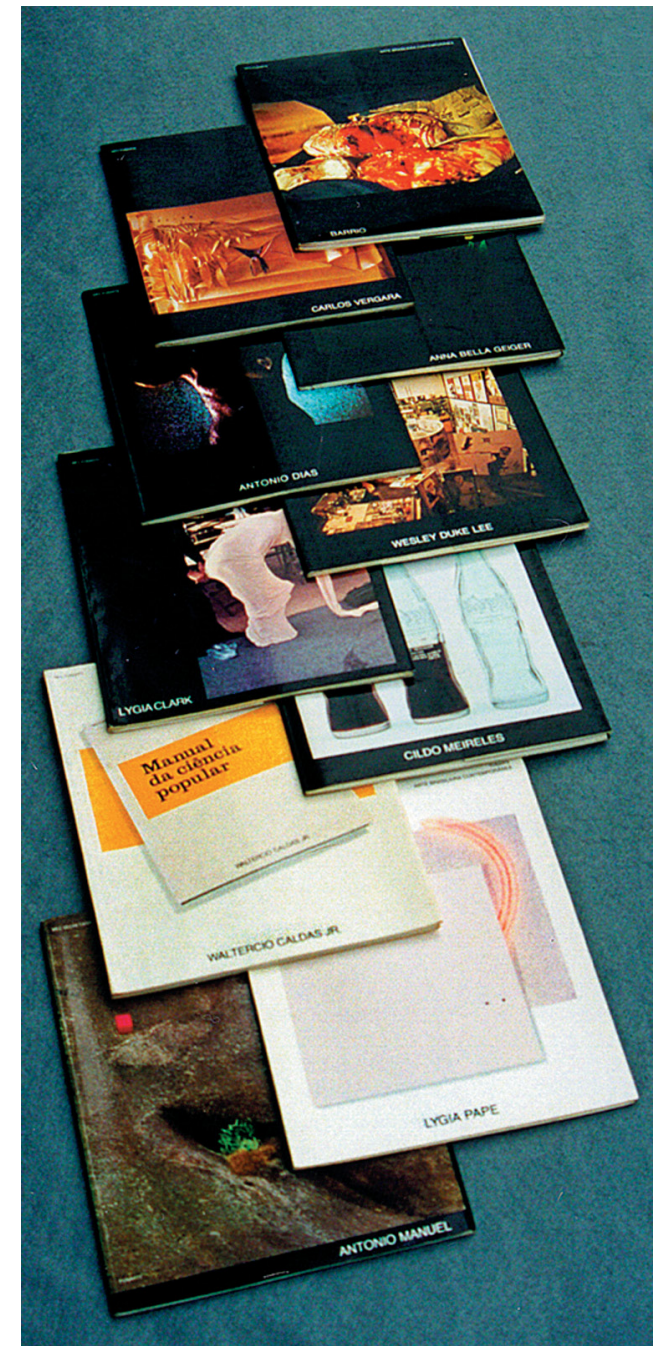

Coleção Arte Brasileira Contemporânea, 1978-1985. Livros de Barrio, Carlos Vergara, Anna Bella Geiger, Antonio Dias, Wesley Duke Lee, Lygia Clark, Cildo Meireles, Waltercio Caldas Jr., Lygia Pape e Antonio Manuel.

\footnotetext{
${ }^{23} \mathrm{O}$ texto de apresentação da série, reproduzido em todos os exemplares, pretendia que ela abrisse "a um público maior a possibilidade de tomar contato com a reflexão e com o debate sobre as tendências atuais e futuras das artes visuais brasileiras". Provavelmente isso foi alcançado em parte. Acho que foram mais úteis, nesse intento, alguns outros projetos da época, como, por exemplo, a diagramação e ilustração originais dos livros para o (então) ginásio Português 1,2,3 e 4, escritos por Domício Proença Filho e Maria Helena
} 

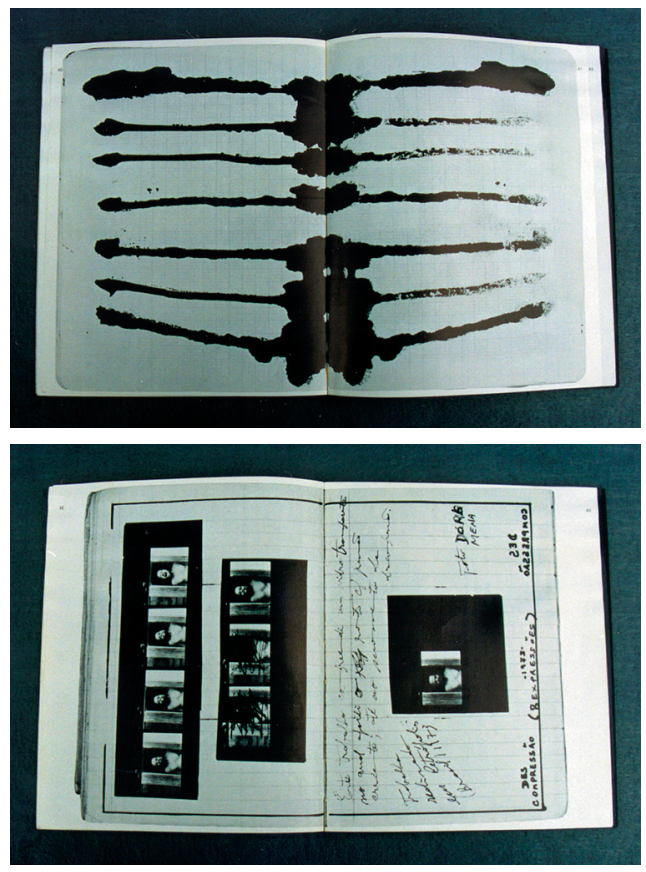

Barrio, Coleção Arte Brasileira Contemporânea, 1978 (reproduzindo páginas dos CadernosLivros).
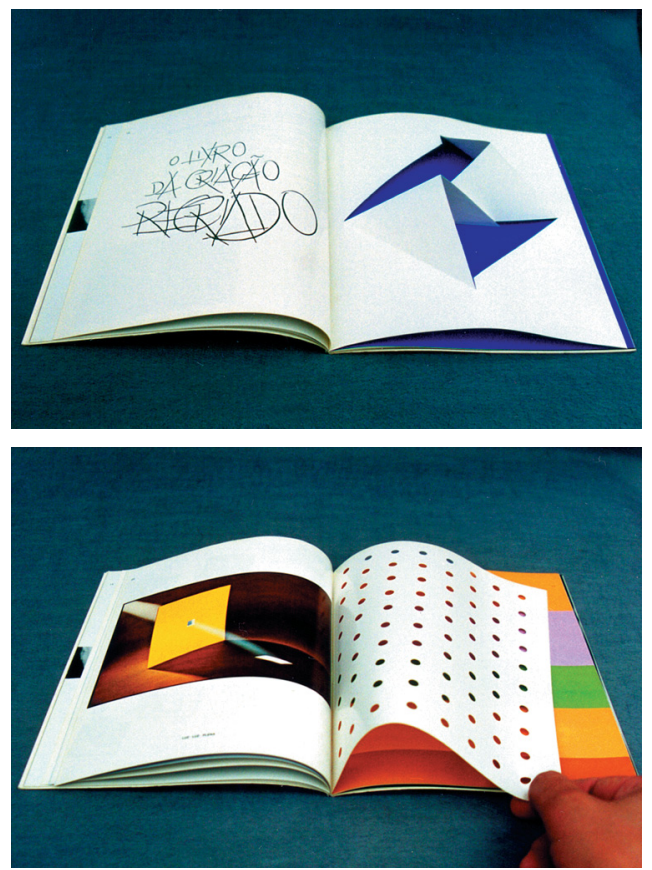

Lygia Pape, Coleção Arte Brasileira Contemporânea, 1983 (reproduzindo algumas soluções do Livro da criação).

mediam o que já está intermediado, afinal o livro já foi idealizado como interface. Sua presença rebanaliza o volume pelo acréscimo de uma teoria discursiva escrita que, embora tenha grande valor por si só, provoca um ruído semântico na obra. Ajuda a normalizar (penso que sem sucesso) o que é elaborado para causar algum grau de estranhamento. De fato, o grande companheiro dos artistas foi o Departamento de Editoração da Funarte. Apoiando os artistas, eles deram corpo a uma proposta editorial ausente do mercado, que hoje se confirma como documentos de primeira linha do intercurso visual com a página em formato brochura, que, pela individuação bidimensional, a reinventa. Mas apesar de tudo, observados duas décadas depois, fica a dúvida de se não há aqui realmente muito mais um exercício de egolatria.

Entre outras edições desse período fértil, estavam Rio, do arquiteto Oscar Niemeyer (Avenir Editora, 1980), e Flicts, do cartunista Ziraldo Alves Pinto (Editora Melhoramentos, 1975). Cada um a sua maneira apresenta questões políticas subliminares ou não ao tema do livro. O de Niemeyer questiona, com forte nostalgia e ressentimento, as alterações sofridas

Duarte Marques. O planejamento artístico da série, do início dos anos 70, era de Fortuna (1931-1994). O exemplar que me sobrou nas mãos, o número 3, com o qual estudei em 1972 tem ilustrações de Antonio Manuel, Antônio Benevento, Fernando V. da Silva, Rubens Guerchman, Luiz Carlos Miranda, Newton de Sá, Cláudio Paiva, Cildo Meireles, Raimundo Colares e Urian. É por causa de volumes como esse que hoje eu respiro arte e livros. 


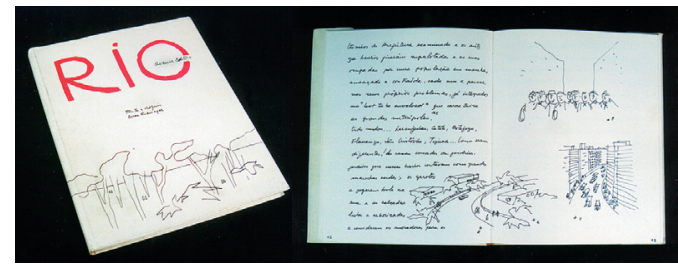

Oscar Niemeyer, Rio, 1980.

na cidade do Rio de Janeiro pela evolução urbana natural e pelo paisagismo de Roberto Burle Marx. É encadernado e com sobrecapa, com branco dominante e impressão em preto. Apenas o título é em vermelho. Todo o texto e os croquis que o acompanham são do autor e manuscritos, sem uso de composição mecânica ou eletrônica.

O livro de Ziraldo inovou profundamente a literatura infantil brasileira ao propor, além de uma nova relação entre texto e imagem, o autor como construtor de um projeto gráfico narrativo. Sem o uso de figuração naturalista, Ziraldo narra os problemas de uma cor deslocada do espectro de nosso imaginário. Flicts é uma cor que não está nos lápis de cor, não está nas bandeiras dos países e não está no arco-íris. O livro tem o dorso grampeado a cavalo, o que contribui para o seu baixo custo. $\mathrm{Na}$ época do seu lançamento, ficava um pouco deslocado no setor de livros infantis, sendo uma obra um pouco gauche. Era extremamente eloquente da sua condição de fruto de um trabalhador gráfico. Foi exposto, justificadamente, na $1^{\text {a }}$ Exposição Nacional de Livro de Artista, 1983, em Pernambuco.

A experimentação gráfica "permitida" parece ser incentivada em produtos infanto-juvenis, em que a noção de público-alvo é muito clara. No aspecto da potencialidade livro-referente dessa experimentação, ela é aplicada a outros objetos que não o códice. Embalagens, jogos, acessórios, muitas criações incorporam soluções elaboradas ou desenvolvidas ou aperfeiçoadas por artistas do livro: técnicas de encadernação sem costura, livros 
com articulações internas (pop-up books), obras com mais de uma lombada, livros que, pelo seu folhear, emulam cenas de animação (flip books), incorporação de processos mistos e objetos, etc. Serviu, e vem servindo à publicidade e às relações públicas, ${ }^{24} \mathrm{o}$ que pode ser considerado uma perversão de uso das mesmas soluções que, por exemplo, vêm produzindo o moderno livro infantil.

Soluções livro-referentes também podem ser encontradas na fonografia. Capas e encartes de discos sempre propiciaram solo fértil para a criação gráfica. Com a chegada dos discos compactos, um novo problema surgiu: como miniaturizar um projeto gráfico que seja, ou pareça, agressivo? De fato, isso já foi resolvido, podendo ser verificado nos balcões das lojas: embalagens inspiradas em livros. Um produto nacional recente é o disco de Caetano Veloso intitulado Livro, de 1997. A remissão ao título é encontrada tanto na embalagem do $\mathrm{CD}^{25}$ como na sua ideação musical. A canção principal, Livros, expressa emoções generalizadas do cantor e do seu público e apresenta o tom passional de um relacionamento com um objeto que é único, por nele caber todas as metáforas.
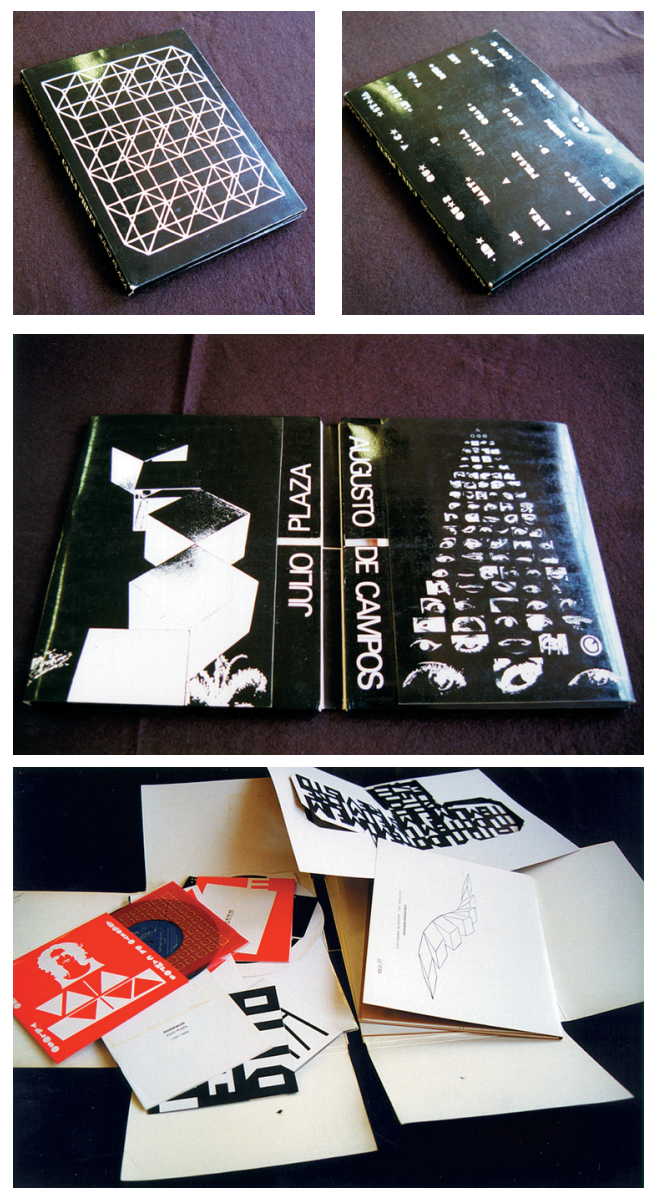

Julio Plaza e Augusto de Campos, Caixa preta, 1975

(com disco de Caetano Veloso).

Dessa forma, encontramos numa manifestação popular uma representação do relacionamento que, em geral, as pessoas parecem ter com os seus livros. A embalagem simula um livro-objeto, com dobras, encarte com as letras em fascículo independente e caixa plástica do $\mathrm{CD}$ subordinada ao projeto (e não o inverso, como é usual). Lembro que Caetano Veloso já musicou poemas concretos e colaborou com um disco (compacto simples de vinil) para a Caixa preta, 1975, livro-objeto antológico (também porque é uma antologia) de Augusto de Campos e Julio Plaza.

\footnotetext{
${ }^{24}$ Como exemplos de transformação das artes do livro em objetos publicitários ver Creative direct mail design, de Sheree Clark e Wendy Lyons, Rockport: Rockport Publishers, 1995. São peças publicitárias agressivas, sim, mas com uma profusão de exemplos extremamente criativos.

${ }^{25}$ Projeto gráfico de Luiz Zerbini, Fernanda Villa-Lobos e Barrão, mais Gê Alves Pinto na criação da embalagem. As pinturas são de Luiz Zerbini.
} 
Do ponto de vista da injúria física do suporte com intuito compositivo, também existem algumas possibilidades de passagem entre o artístico e o industrial, ainda que elas sejam reduzidas. Nesse caso, a indústria gráfica utiliza aquelas ideias que podem ser convertidas (para multiplicação) em calandras de relevo ou em lâminas de corte. Tomemos como exemplo a punção física, o traspassar através do furo, um rompimento perpendicular de superfície que quer parecer um dano. $O$ furo é aqui entendido como um pequeno recorte, uma pequena remoção de matéria. É uma das intervenções na página que possui um vínculo mais estreito com a ideia de ferimento. Ele é agressivo pela sua própria constituição como vestígio de um gesto que repentinamente, no passado, rompeu um plano que se esperava preservado. Sua perpendicularidade é intrínseca porque raramente concebemos uma ação oblíqua. Ela obriga o olhar a um percurso espacial, oposto ao trajeto bidimensional, esperado para uma página plana (atenção: nesse momento deste trabalho, "página plana" é um pleonasmo). $\mathrm{O}$ olho atravessa em abismo a própria ideia da serialidade encadernada. Existiu um momento em que o ritmo do processo foi alterado para a execução do furo. Mas o orifício é presente. Ele não é episódico, passageiro. O gesto que o faz, sim, tem o caráter de episódio. O gesto criou o furo, agora um elemento compositivo conformado pela ausência - a remoção parcial da matéria que deixa visualizar uma etapa. Abruptamente nos conscientiza da totalidade do volume no espaço, costurando com o negativo a união de suas partes. Ele impede a leitura tradicional, sem, contudo, transformá-la em randômica. Uma nova direção ordenada é acrescentada. Agrega à leitura uma nova possibilidade de acesso, obrigando à percepção da obra plástica em detrimento da obra gráfica.

No livro convencional brasileiro experiências parecidas ou derivadas podem ser encontradas de forma diluída, possibilitadas pela proximidade do público produtor ou consumidor de arte. Essa intromissão pode ser demonstrada, rapidamente, por dois exemplos que circulam entre nós, mas que não são, de modo algum, livros de artistas, mas sim objetos comerciais, elaborados por programadores visuais inseridos em questões da arte. O primeiro é um caso de elaboração de capas para brochuras, e o segundo, um caso de miolo (corpo de páginas). Veja-se os recortes das capas da série da Editora Companhia das Letras a partir dos cursos livres da Funarte Os sentidos da paixão, O olhar e $O$ desejo. ${ }^{26} \mathrm{Em} O$ olhar, 1988, a proposta gráfica alcança um maior grau de completude, pela maior adequação entre forma e conteúdo (o tema dos ensaios). Nesses casos, o furo é na verdade um recorte, talvez um eco dos trabalhos de Lucio Fontana. Isso pode ser considerado como indefinido, já que essa relação é ambígua, dizendo respeito à tensão estabelecida entre a dimensão do material que foi removido e a área que permaneceu intacta. A transformação de um orifício em recorte é principalmente uma questão de escala, de proporção. Mas um recorte é uma abertura, e, como tal, revela algo em ocultamento. Ou, se não o revela, ao menos nos propicia essa sensação de segredo exposto, adicional ao esperado mostrar e esconder

\footnotetext{
${ }^{26}$ Projeto gráfico de Moema Cavalcanti.
} 
pressuposto em qualquer códice (ou caixas). Além disso, coloca em simultaneidade temporal a admissão do projeto e o resultado final da operação artesanal (ou industrial). Não é, como já foi indicado, um ferimento, mas o entendimento simultâneo de dois momentos construtivos. E é apenas eventual na indústria gráfica para adultos.

O furo (furo mesmo), como presença na produção industrializada, ganha status de elemento individualizado em obras infantis ou em títulos que admitem alguma liberdade formal, como 50 anos de Salão Paranaense de Belas Artes, 1995, livro comemorativo ${ }^{27}$ publicado pelo Museu de Arte Contemporânea do Paraná.É encadernado com capa dura e possui impressão colorida. Um único furo de cerca de cinco milímetros de diâmetro atravessa capa e miolo de fora a fora, perpendicularmente. Em alguns momentos ele compõe com os elementos gráficos, em outros não, persistindo na lembrança de sua autonomia. Às vezes parece um alvo, às vezes parece uma inconveniência, já que - não importa o rigor da diagramação - ele sempre se afirma como evento autônomo no espaço. $\mathrm{O}$ curioso é que o livro também funcionaria bem sem ele. Na dúvida, com o auxílio de um prego, pode-se pendurá-lo na parede.

Se passei muito rapidamente pelo que "talvez seja" e pelo que "não é", é porque preciso chegar no que "passa a ser". Aproveito o comentário anterior para destacar o papel do catálogo de exposições nesse contexto de ambiguidades. Ele é uma peça comercial de relações públicas e vendas, muito mais do que o nobre registro de um evento. Mas ganha a qualidade de livro de artista quando o grau de personalização e as soluções gráficas e plásticas envolvidas alcançam o campo da arte. Muitos catálogos são, por isso, autênticos livros de artista. Claro está que muitos livros são produzidos para acompanhar exposições, com o suporte financeiro de galerias e museus. Mas destaco, neste momento, os catálogos mesmo.

Uma produção recente demonstra a mestiçagem de um catálogo convencional pela "contaminação" (ou parceria) do livro de artista. É o caso da exposição Ocupações/ Descobrimentos, de Antonio Manuel e Artur Barrio, em maio e junho de 1998, no Museu de Arte Contemporânea de Niterói, no Estado do Rio de Janeiro. Ambos são artistas brasileiros nascidos em Portugal, e a mostra buscou inserção nos festejos dos 500 anos de descobrimento do Brasil. A peça gráfica que a acompanhou é composta por uma pasta de papelão ondulado com elástico e impressão "rústica". Dentro há um folheto sobre a mostra e os artistas e um catálogo individualizado para cada um, ambos em cores. O de Antonio Manuel é uma publicação comercial, de visualidade

${ }^{27}$ A autoria é de Maria José Justino e o projeto gráfico é de Silvio Silva Junior.

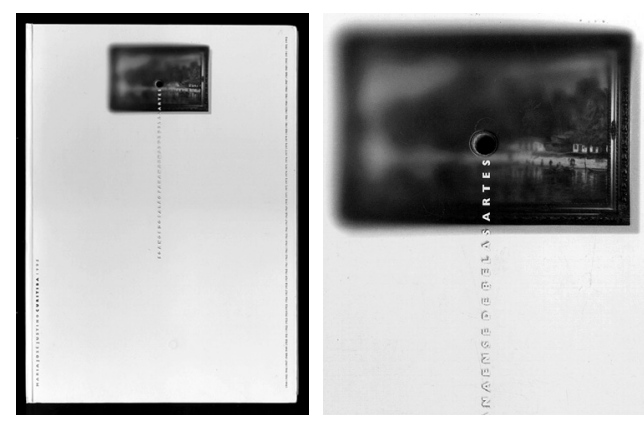

Capa e detalhe da capa de 50 anos de Salão Paranaense de Belas Artes, 1995. 
publicitária, com algumas das soluções (cacoetes) da moda. É bonito. O de Barrio é um livro de artista manuscrito, com alguns desenhos e fotos. É impresso em fac-símile, dentro de seu estilo próprio. De um lado, a divulgação busca a arte, e, de outro, a arte busca a divulgação, num toma-lá-dá-cá. $\mathrm{O}$ catálogo da dupla exposição é, assim, fruto da convivência, nesse caso pacífica (porque é provavelmente lucrativa), da arte e da publicidade. Quem se apropria do quê?

Passemos, agora, para um exemplo, digamos, mais "puro", o catálogo Exbibition space, 1995. Ele é a própria exposição dos alunos de artes do California Institute of the Arts, das turmas em curso. É um livro comum de formato usual $(23 \times 16 \mathrm{~cm})$, com capa dura branca, sem texto. O título está num carimbo aplicado na face externa de corte do miolo (na superfície refilada). As 160 páginas são em offset, uma impressão em preto, e serrilhadas para serem destacadas. O comprador pode (ou deve) arrancar as páginas e montar a mostra no espaço que lhe aprouver. Ele destruirá o catálogo, mas em compensação terá uma exposição só para si. Esse catálogo é um livro de artista evidente e evidenciador. É resultado do eco das muitas discussões nos anos precedentes sobre o papel do livro como espaço alternativo (veja-se a esse respeito, artigos como o de Welish, 1981, e Moeglin-Delcroix, 1996).

Esse trabalho, como outros, é uma
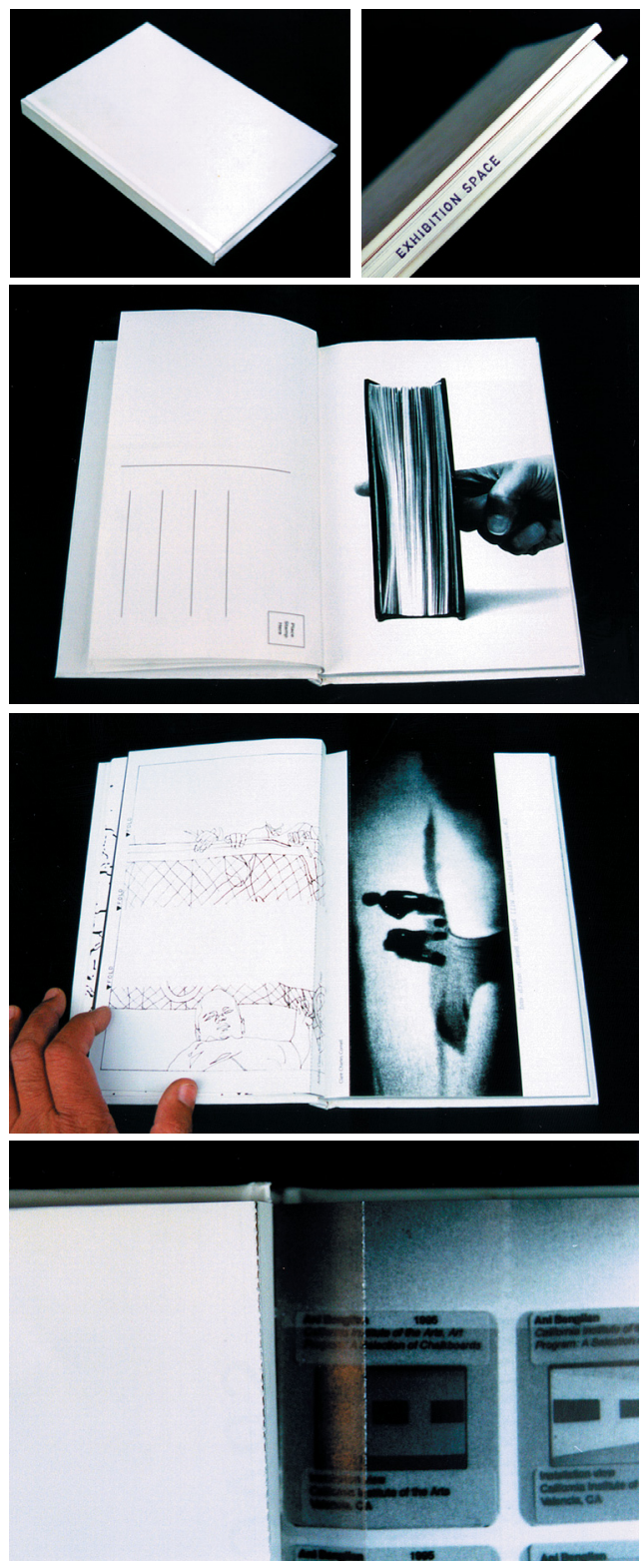

California Institute of the Arts, Exhibition space, 1995, 78 artistas. ressonância das experiências pioneiras de Andy Warhol e Seth Siegelaub, especialmente o último. Segundo Germano Celant, Warhol teria sido o primeiro artista a produzir seu próprio catálogo de exposição, em fevereiro de 1968, para o Moderna Museet, de Estocolmo. Era composto por escritos de Warhol, repetições obsessivas de fotos de seus trabalhos e fotos registrando pessoas e eventos de sua Factory. Toda a informação estava sob o controle e responsabilidade do próprio artista. Para Celant, "esse livro é o primeiro protótipo de informação como 
obra de arte, distinta da obra conceitual por causa de seu uso linguístico da fotografia como o oposto de usá-la como documentação" (Guest e Celant, 1981, p.104, nota 4).

Seth Siegelaub encenou uma participação mais aguda na criação de novas possibilidades para o catálogo. Era um empreendedor inquieto, que, de 1964 a 1966, dirigiu uma galeria de Nova York com postura convencional. Depois passou a trabalhar com os jovens artistas conceituais, o que lhe pos-

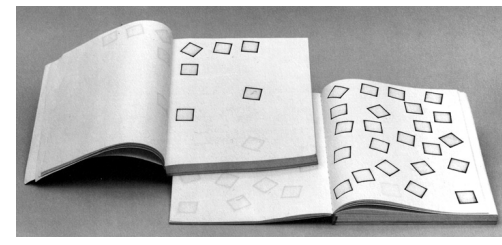

Seth Siegelaub e John Wendler, orgs. Carl Andre, Robert Barry, Douglas Huebler, Joseph Kosuth, Sol LeWitt, Robert Morris, Lawrence Weiner

(mais conhecido como The xerox book), 1968 sibilitou gerenciar novos caminhos de ruptura. Em 1968, sem galeria permanente, publicou catálogos que completavam (ou participavam como peças principais) as exposições de Douglas Huebler (novembro) e Lawrence Weiner (dezembro). Ao mesmo tempo, publicou com John Wendler uma antologia da fotocópia (impressa em offset) intitulada Carl Andre, Robert Barry, Douglas Huebler, Joseph Kosuth, Sol LeWitt, Robert Morris, Lawrence Weiner, mais conhecida como The xerox book, com 25 páginas por artista. Após esses trabalhos, ainda seriam publicados catálogos dominantes para as exposições de janeiro, março e julho de 1969. A primeira exposição a existir apenas na forma de catálogo foi March 1-31, 1969 (Lippard, 1997, p.79). Para Siegelaub, poder era "alcançar muitas pessoas rapidamente".

Talvez pareça cínico, mas eu tendo a pensar que a arte é para artistas. [...] É aí que eu entro. $\mathrm{O}$ caso é "objetivar" o trabalho do artista. [...] É meu interesse fazê-lo conhecido às multidões. [...] A arte que me interessa pode ser comunicada com livros e catálogos. [...] Mas quando a arte não mais depende de sua presença física, quando se tornou uma abstração, ela não é distorcida e alterada por sua representação em livros e catálogos. Ela se torna informação primária, enquanto a reprodução da arte convencional em livros ou catálogos é necessariamente informação secundária. [...] Quando a informação é primária, o catálogo pode se tornar a exibição $e$ um catálogo auxiliar a ela, enquanto que na exposição Janeiro, 1969, o catálogo foi primário e a exibição física foi auxiliar a ele. (Lippard, 1997, p.124-126)

Para a afirmação de Hudnilson Jr. (Caderno de arte xerox, 1984) de que "ocorre sempre a apropriação de um novo veículo para a divulgação de uma velha proposta", referindo-se ao uso de fotocopiadoras, pode-se fazer uma inversão no pensamento e aplicá-lo ao livro. Ocorre muitas vezes a apropriação de veículos antigos para a divulgação de propostas renovadoras. O uso da fotocopiadora é veículo na cozinha do original de cada página do Xerox book, mas não é uma proposta quando entendido pelo ponto de vista do projeto de uma mostra que é catálogo que é livro. Poderia-se argumentar que a xerografia não tenha propiciado uma arte xerox. Esse conceito parece ter sido uma perversão, na medida em que a xerografia foi muito mais uma ferramenta ou um procedimento componente de práticas ou categorias maiores. Afirmar a existência de uma categoria chamada "arte xerox" pode significar uma regressão à mistificação da obra tradicional, enquadrada pela sua técnica ou ferramentas, em detrimento da obra contemporânea, enquadrada pela 
sua mídia ou instrumental. Nesse sentido, seria possível aceitar a arte xerox como uma componente comum a muitas categorias maiores (ou menos menores) como a arte postal, o livro de artista e a performance.

Em entrevista telefônica para Christophe Cherix, em 1996 (um de Genebra e o outro de Amsterdam), Siegelaub comenta a inserção do Xerox book na exposição de 1994, curada por Castleman.

[...] talvez ela o tenha entendido como algum tipo de "Meisterwerk"; totalmente além do alvo, mas perfeitamente de acordo com as "altas" ideias de arte preciosa do MoMA. [...] Esse é um problema essencial da história na arte: a avaliação de um produto cultural no contexto de sua criação original. Eu fui recentemente sondado sobre fazer uma mostra sobre o Xerox book, e as pessoas envolvidas estavam muito excitadas porque elas sentiam que tinha algo a ver com o uso da excitante técnica de xerocar coisas.

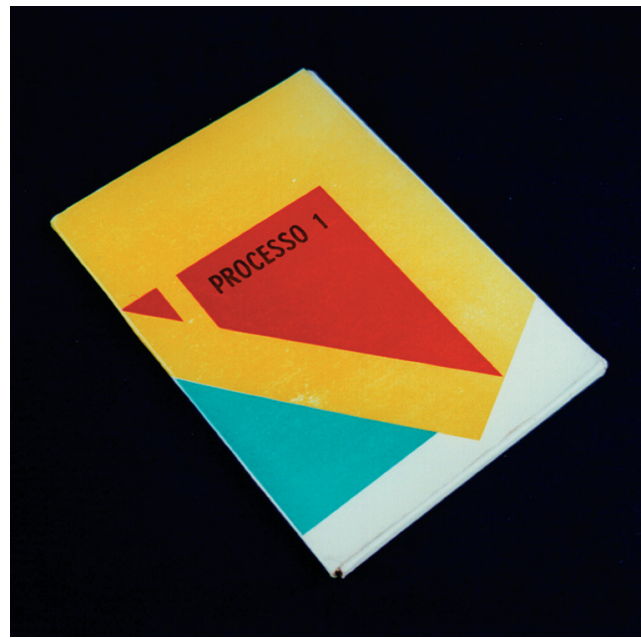

Revista Processo 1, Rio de Janeiro, 1969.

Com quinze envelopes com obras e documentos do poema-processo. Participação de Alvaro de Sá, Neide Dias de Sá, Anselmo Santos, J. P. Ribeiro, Sebastião de Carvalho, J. Cláudio, Plínio Filho, Wlademir Dias Pino, Ronaldo Werneck e Pedro Bertolino.

\section{C.C.: Mesmo sendo o Xerox book impresso?}

S.S.: E quem se importa? Para mim, ele não tinha absolutamente nada a ver com xerocar, de qualquer maneira. Aquilo não foi sobre a agradável ou excitante técnica do xerox, mas sobre fazer algo diretamente, de modo barato, fácil, rapidamente. ( $3^{\text {rd }}$ ArtistBook..., 1996, p.11-12)

Também as revistas, quando sensibilizadas, ingressam nesse espaço entre arte e comunicação. Revistas de arte pertencem à esfera da mídia impressa, são geralmente produzidas por lucro (ou perdas calculadas) ou apoios institucionais, e normalmente sob os cuidados de um jornalista responsável. Mas a alteração de sua função pode credenciar um periódico à aura de objeto artístico. Uma possível "revista de artista” pode ser localizada dentro do universo da (chamemos assim) livro-arte, com problemas conceituais parecidos. Com antepassados como os projetos de Lissitzky, Schwitters e Van Doesburg, algumas revistas a partir dos anos 60 foram produzidas por artistas para questionar a natureza da obra de arte, ao mesmo tempo que faziam arte especificamente para disseminação através de um meio de comunicação de massa. O próprio grupo criador de sua revista Art-Language se questionou sobre isso no editorial do primeiro número, de 1969. Seria possível, por isso, falar de uma magazine art, "arte concebida especificamente para um contexto de revista e, por essa razão, arte que é realizada somente quando a própria revista estiver composta e impressa" (Phillpot, 1980, p.52). 
Deixando de lado os precedentes, certamente importantes, mas que alongariam esta reflexão, lembro da presença no Brasil, entre outras, das publicações do movimento do poema-processo, menos divulgadas hoje do que deveriam, possivelmente pela pouca presença de desenvolvimentos escritos. Durante sua curta duração, o movimento produziu as revistas Ponto 1, em 1967, Ponto 2, em 1968, e Processo 1, em 1969, todas elas compostas por trabalhos de seus integrantes. A primeira tem apresentação de portfólio, com capa e páginas soltas in-fólio, com textura e gramatura homogênea. A segunda tem forma de pasta de documentos (do tipo caixa), com páginas soltas normais ou in-fólio, de diversas gramaturas e texturas. A terceira é a mais elaborada. Continua como pasta, mas os trabalhos são agrupados em quinze envelopes pardos diferentes, com impressão tipográfica no seu exterior. Cada envelope possui trabalhos de um participante, com formatos, texturas e procedimentos variados. A ideia de página passa a ser exponencial, na medida em que cada envelope é, de fato, página, com outras páginas dentro. Como o poema-processo buscou um afastamento máximo da verbalização, sua divulgação procurou vários canais: mídia impressa convencional, cursos, passeatas, acontecimentos e exposições. Sua característica experimentação dos limites da indústria cultural, da visualidade e da poesia, alimentada pelos novos conhecimentos de comunicação visual, fez dela um dos precursores da arte postal no País.

Se alguns integrantes do poema-processo, entre outras experiências, pesquisaram na prática e na teoria as histórias em quadrinhos (notadamente Alvaro de Sá e Moacy Cirne) nos seus aspectos semiológicos, um grande número de artistas mundiais o fizeram em outras instâncias pós-pop. Ressalte-se que para alguns os quadrinhos são

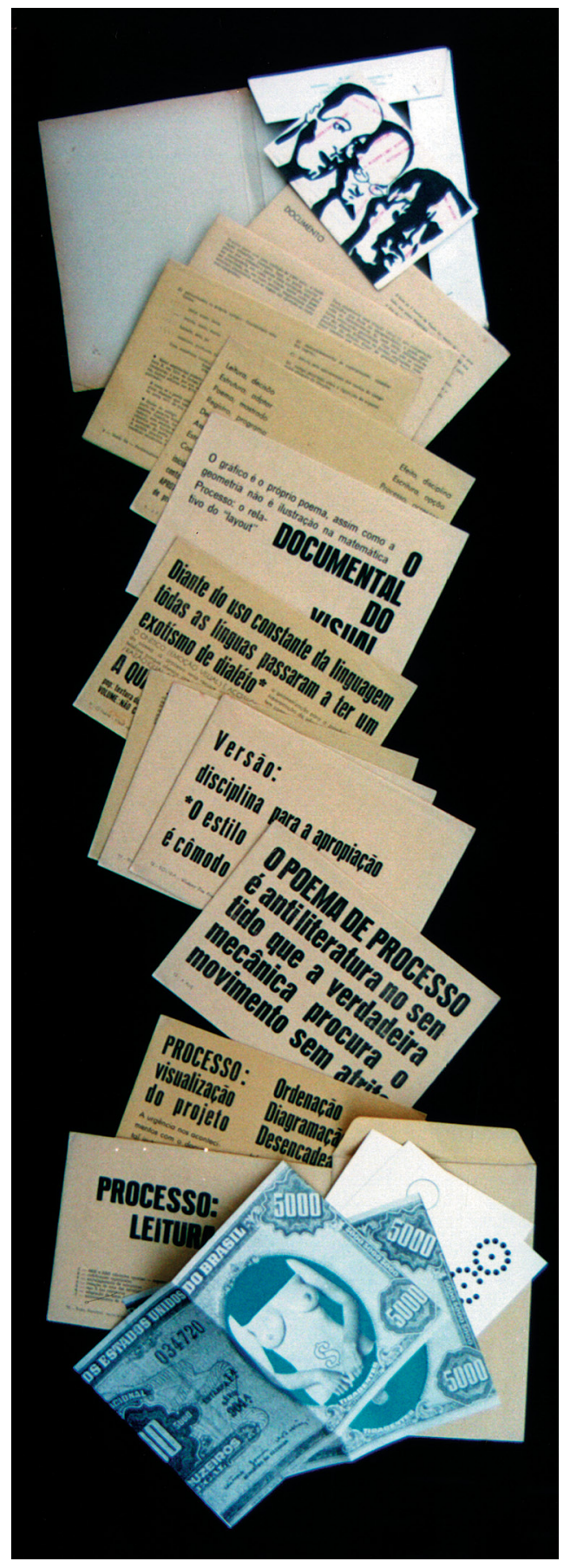

Revista Processo 1, Rio de Janeiro, 1969. 
revistas e para outros são livros seriados, que podem, tanto num caso como no outro, extrapolar sua função evasiva, alcançando possibilidades estéticas e narrativas diferenciadas. Dentre os nomes recentes que inserem seu trabalho na arte, estão os da dupla Simon Grennan e Christopher Sperandio, o primeiro inglês e o segundo norte-americano. Morando em continentes diferentes, eles desenvolvem seu trabalho através da internet e de viagens. Buscam interagir com uma grande variedade de pessoas, tanto no consumo, como na produção da obra de arte, que é baseada em experiências compartilhadas com participantes não-artistas. Declaram ter-se tornado "interessados de modo crescente com as maneiras com que as pessoas se motivam a fazer escolhas sociais e estéticas. Concentramos nossa atenção na análise do entretenimento como fenômeno de estímulo ou motivação" (Grennan e Sperandio, 1999). Seus projetos são financiados ou propostos por museus e instituições como o Museum of Fine Arts, de Boston, Tate Gallery ou o Institute of Contemporary Arts, de Londres. São quadrinhos aparentemente tradicionais, mas construídos com os recursos da computação, como a vetorização de imagens.

Em Revenge, 1997, são recontadas quatro histórias, cada uma delas contada por um de quatro amigos de Birmingham, Inglaterra (onde está sediada a patrocinadora do livro, Ikon Gallery). São absolutamente banais, apesar de seus narradores as imaginarem como reveladoras. Deste modo, um fato é contado (portanto, traduzido) para um novo narrador (portanto retraduzido). O toque pitoresco fica por conta da necessidade de leitura através de óculos 3D de papel (fornecidos juntos), que darão uma
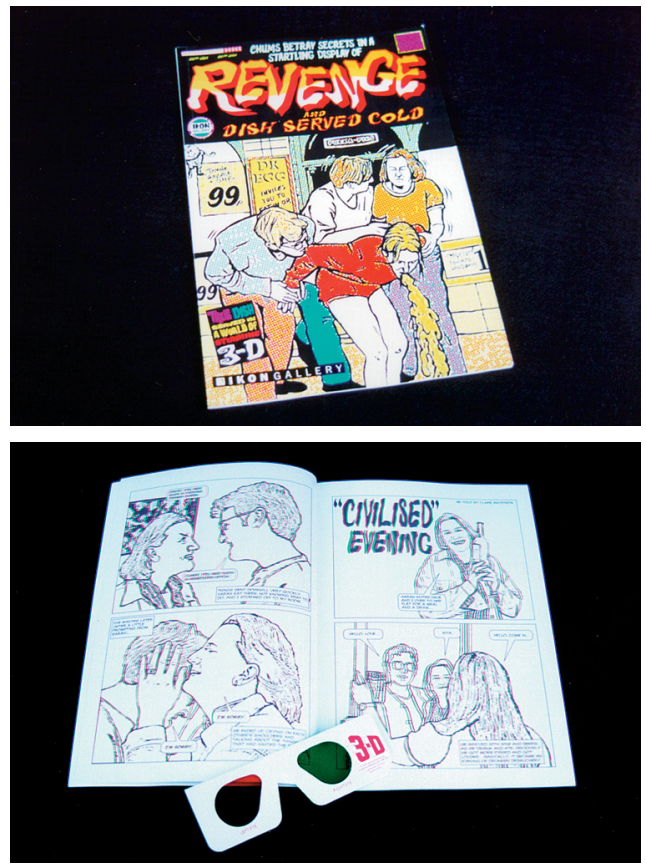

Simon Grennan e Chistopher Sperandio, Revenge, 1997.
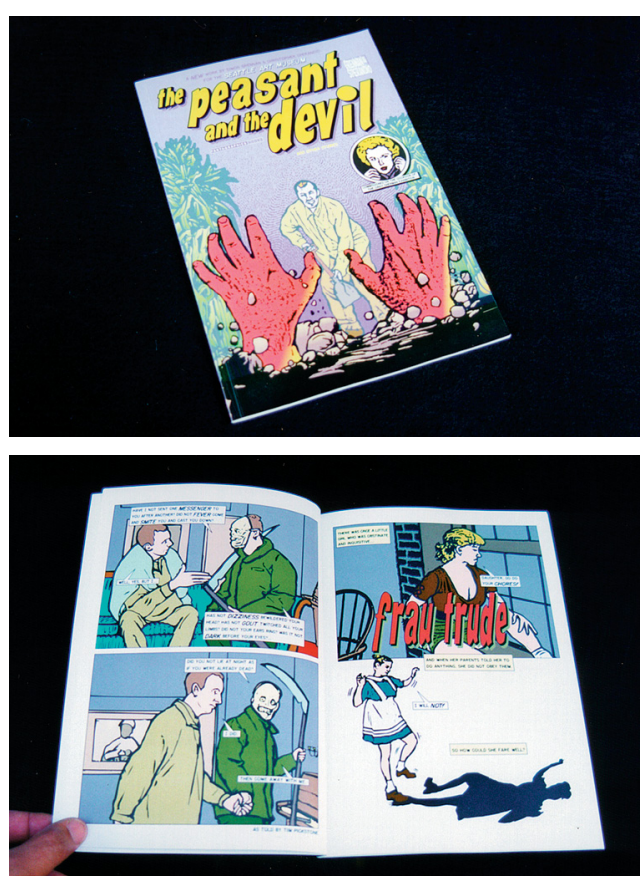

Simon Grennan e Chistopher Sperandio, The peasant and the devil, 1998. 
irônica "profundidade" à trama. E que ao induzirem a uma outra realidade privativa do nosso cérebro, oporão novo obstáculo ao fato original.

The peasant and the devil, 1998, foi executado para o Seattle Art Museum como peça gráfica paralela à exposição de Cindy Sherman, Allegories. A partir de algumas fotos de (e com) Sherman, e de uma proposta sobre imagens de imagens e do papel da mulher, eles narram em enésima geração quatro contos morais populares ("Mensageiros da morte", "Frau Trude", "O camponês e o diabo" e "O piolho e a pulga"), todos eles segundo o recontado por seus amigos. A estética popular dos quadrinhos é ressemantizada por uma estranha e inesperada forma de escapismo. Aqui, o mito, a fábula e a natureza humana são apresentados em uma proposta divertida de alegoria, que comenta o banal pelo humor que a arte também pode oferecer. Não poderia ser considerado um tipo de "paracatálogo"?

Por fim, cabe registrar que a exposição The Next World, ocorrida de setembro de 1998 a janeiro de 1999 em Purchase, nos Estados Unidos, teve como proposta a abertura das fronteiras entre arte, poesia e projeto gráfico. A curadoria foi de Johanna Drucker, também especialista em tipologia e palavra impressa. Embora a maior parte dos trabalhos expostos fosse de livros de artista no sentido estrito, também havia a presença de exercícios de comunicação visual, poesia visual e fanzines.

\section{Ingresso da gravura: objetificação em espetáculo solo}

Em 1996 foi lançado em Porto Alegre o primeiro número da revista PublicAções. A edição era composta por trabalhos "originais", assinados e datados, de dezesseis brasileiros e uma argentina. ${ }^{28} \mathrm{Cada}$ um colaborou com um trabalho. Foram executados setenta exemplares. Destes, cinquenta para o comércio, sob a coordenação de Maria Conceição Menegassi (1954-1997). Os trabalhos, ou as páginas, são na maioria gravuras de técnicas tradicionais. Uns poucos têm cortes, recortes ou uso de fotocopiadora. A capa é o reaproveitamento de chapas de impressão offset, com sobreimpressão em serigrafia. A revista pretendia agitar um pouco o meio local, muito relacionado com a gravura. Isso não foi possível. Tinha problemas naturais de um número inicial. Além disso, a edição seguinte não teve divulgação adequada. Devido ao prematuro falecimento de Conceição, seu projeto acabou.

A revista era bonita. Então qual era o seu problema? Era ser bonita. É a tipificação desse "ser bonita". Ou ao menos era o que sua coordenadora parecia entender. Pouco depois de seu lançamento, Conceição, a quem eu havia conhecido formalmente havia

\footnotetext{
${ }^{28}$ Jane Cravo Souza, Ana Luz Pettini, Anete Abarno, Carmem Vieira, Giuliana Adomilli, Helena Kanaan, Jane M. Godoy Becker, Karin Kopittke, Lilian Goldani, Luiz Roberto Pecoits Targa, Lurdi Blauth, Mara Caruso, Maria Conceição Menegassi, Maria Helena Pacheco, Theresinha Boff Reis, Sérgio Claudio de Franceschi Lima e a argentina Matilde Marín.
} 
pouco tempo (em uma oficina sobre livro de artista em que ambos participávamos), procurou-me para saber se compartilhava de sua opinião. Acreditava que sua revista apresentava um desequilíbrio: "Ela tem gravura demais". Pensava que a presença da gravura estava pouco integrada no fato editorial. Sentia seu peso visual como excessivo. Planejava para o próximo número uma participação maior de recortes e elementos lúdicos. Talvez ela tivesse razão. É difícil julgar, já que não tenho mais informações sobre esse ponto específico de suas ideias, só me restando a memória. Mas de sua consciência da revista como obra livro-referente não há dúvidas, tendo em vista o seu interesse, então ampliado pelo contato com a artista argentina Matilde Marín.

De fato, parece existir um estranho impedimento de integração por parte da gravura, salvo as exceções vanguardistas. Com frequência ela faz a própria propaganda, realça o seu caráter de processo sobre a superfície. Sua contribuição para o livro de artista pode ter sido contaminada pela defesa do gesto precioso, da habilidade manual como criadora. Sabemos (ou imaginamos) que o artista tocou o papel, num procedimento enaltecido pela história. Talvez tenhamos receio de interromper sua perpetuação. Esse sabor de ritual é compartilhado por nós e agrega nobreza. A qualificação tátil e espiritual é mais da instância do livro-objeto do que do livro de artista estrito, conceitual. Também confirma e legitima as pequenas tiragens, ao mesmo tempo que isso se dá em sentido inverso.

De plana, uma gravura passa a parecer espacial, se comparada com os processos de reprodução industrial. Na prática de ateliê, quase só se pode juntar texto adicional a ela
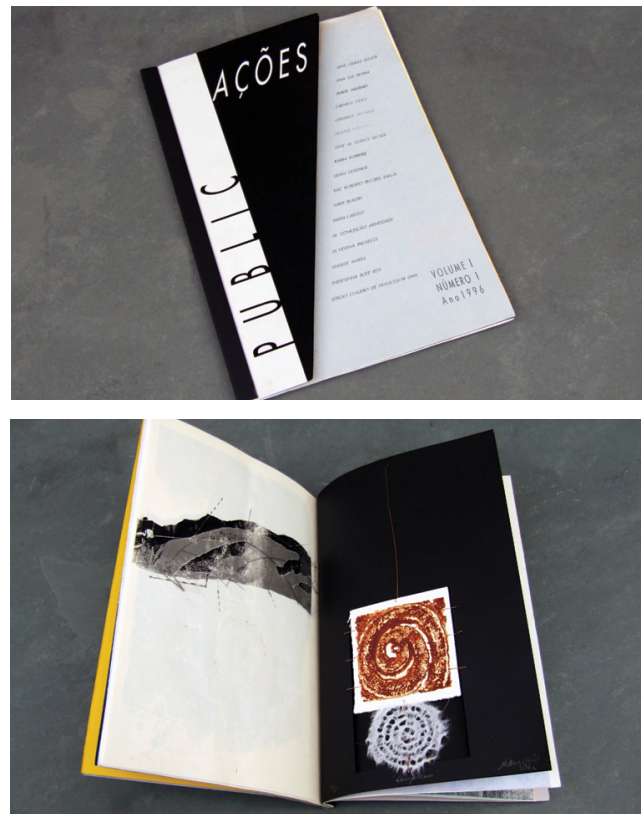

Revista PublicAções, Porto Alegre, 1996, dezessete participantes; abertura entre as páginas de Mara Caruso (esquerda) e de Maria Conceição Menegassi, organizadora (direita).
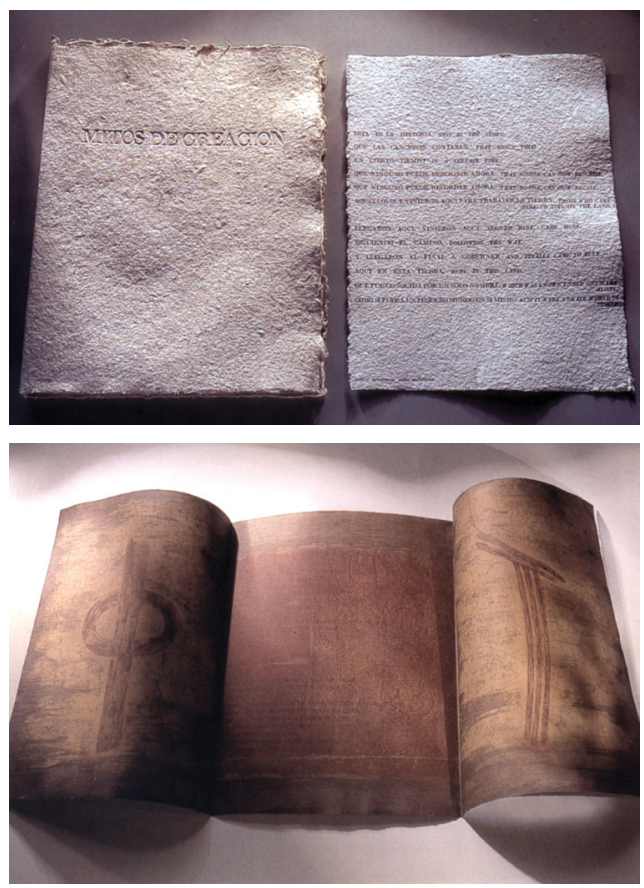

Matilde Marín, Mitos de creación, 1993 (fotos cedidas pela artista). 
se for em tipografia, o que só faz aumentar essa sensação. Mesmo se ferir o suporte, a gravura será terna.

A gravura é discreta mesmo com os seus próprios métodos de divulgação. Assume uma face pequeno-burguesa no bom sentido, porque fornece acesso à obra por um preço mais ou menos reduzido. Assume uma face pequeno-burguesa no mau sentido, porque parece ser tão mais apreciada quanto mais apurada for a sua técnica, em detrimento de sua proposta. A diferença entre assumir esse lado pequeno-burguês e ter a pretensão da vulgarização é da ordem do discurso político que afirma seus objetivos.

Existem pontos comuns entre Neuf dessins de Sotéro Cosme, 1933, de Sotero Cosme (1905-1978), e o portfólio (talvez sem título), 1974, de Romanita Disconzi, apesar de estarem inseridos em momentos diferentes da arte brasileira. $\mathrm{O}$ trabalho de Cosme foi publicado em Paris. É um álbum de gravuras soltas com $39 \times 28 \mathrm{~cm}$, no qual a capa protetora é apenas uma folha mais espessa dobrada ao meio, como uma pasta. É fruto de um jovem artista de 19 anos que estaria comprometido com os efeitos do modernismo brasileiro no Rio Grande do Sul. Todas as imagens são
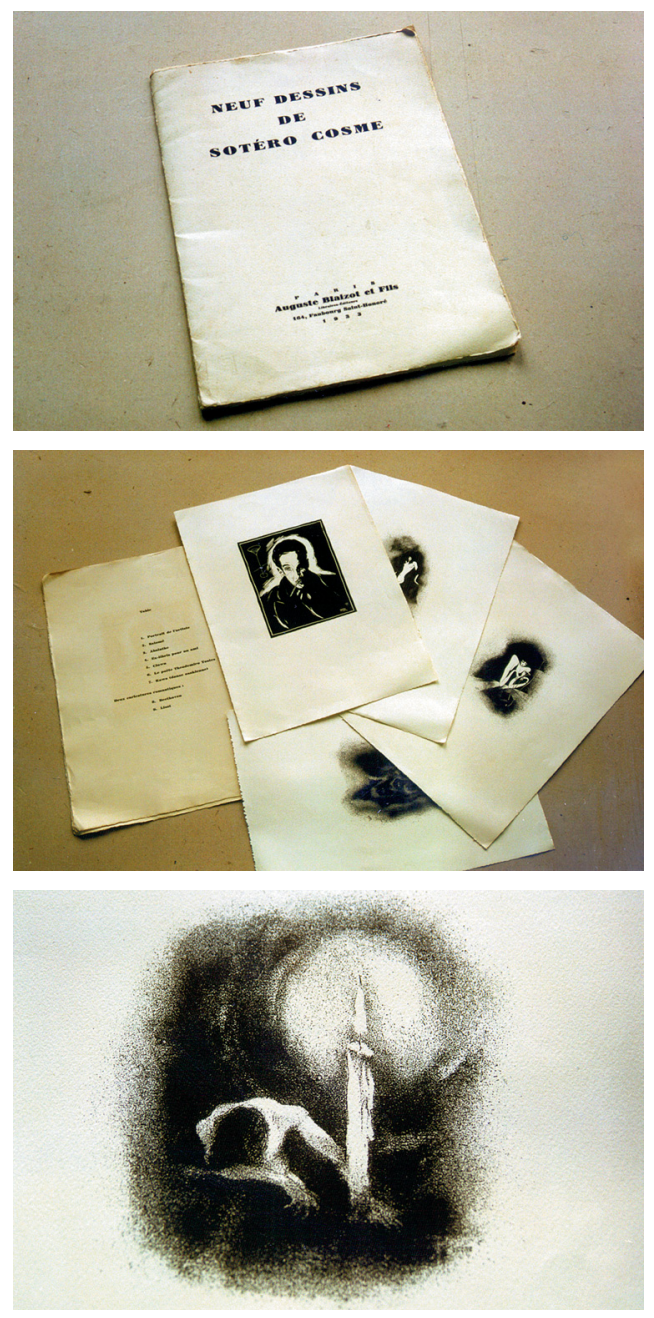

Sotero Cosme, Neuf dessins de Sotéro Cosme, 1933. figurativas e com um certo tom entre o expressionista e o decô. Estão inseridas em padrões de gosto internacionais da época, sem regionalismo, premonição da própria biografia de Cosme. São todas em preto. Dentre elas, uma é intitulada $E x$-libris pour un ami. Teve tiragem de duzentos exemplares.

O trabalho de Romanita é também um conjunto de gravuras, oito, em serigrafia. Cada uma tem uma cor. Estão acondicionadas em envelope do tipo pasta, com formato $32 \mathrm{x}$ $26 \mathrm{~cm}$, portanto um pouco menor que a obra de Cosme. Não possui imagens figurativas. O exercício é desenvolvido pela referência ao seu processo, através das distorções óticas de frases como My book has a dark blue cover ou How much does that typewriter weigh?. Individualmente, cada gravura é assinada, datada e titulada Book Three - Lesson One I até VIII. A tiragem foi de quinze cópias. Sobre a capa, a impressão Romanita 74 poderia ser o título ou uma caracterização de obra como portfólio. 
A rigor não existem diferenças qualitativas entre os dois trabalhos, o que nem sequer importaria aqui. Também não importa a presença ou não da palavra. Eles são equivalentes. A diferença pode ser encontrada no contexto. A obra de Cosme foi colocada no mercado numa posição acessória tanto ao comércio em galeria, quanto ao comércio em livrarias. Se aplicarmos os conceitos de livro de artista (e seus correlatos) a ela, constataremos que para alguns autores, mesmo nos anos 90, o álbum de gravuras de Cosme não pertenceria ao reino dos livros de artista, tanto menos quanto mais o referenciarmos ao sentido estrito. Essa pretensão poderia ser considerada uma afronta. Já o portfólio de Romanita é apresentado respaldado pelo meio de vanguarda dos anos 70 de Porto Alegre, e autenticado como livro de artista pela exposição Arte Livro Gaúcho: 1950-1983. Esse evento, com curadoria de Vera Chaves Barcellos, congregou o arquivo do mais importante núcleo alternativo do Estado (hoje extinto o núcleo, não o arquivo), o Espaço NO (de "nervo óptico"), e o principal agente legitimador, o Museu de Arte do Rio Grande do Sul.

Imaginar um possível isolamento de Cosme com o livro seria uma imprudência, quando não uma impertinência. Homem do mundo pragmático (que inclusive fazia anúncios de suas próprias obras), ele conhecia a mídia, trabalhava nela, além de ter no seu irmão Walter, artista gráfico, um elo a mais com o mundo editorial. Cosme, como Disconzi, tinha a consciência da reprodução e o objetivo da publicação. Sem a chancela das últimas vanguardas, o álbum de Cosme ficaria equilibrado entre a gravura e o objeto gráfico. Mesmo numa posição de limite, entendo que tal obra deva pertencer ao campo do livro de artista lato. Além do mais, ser um

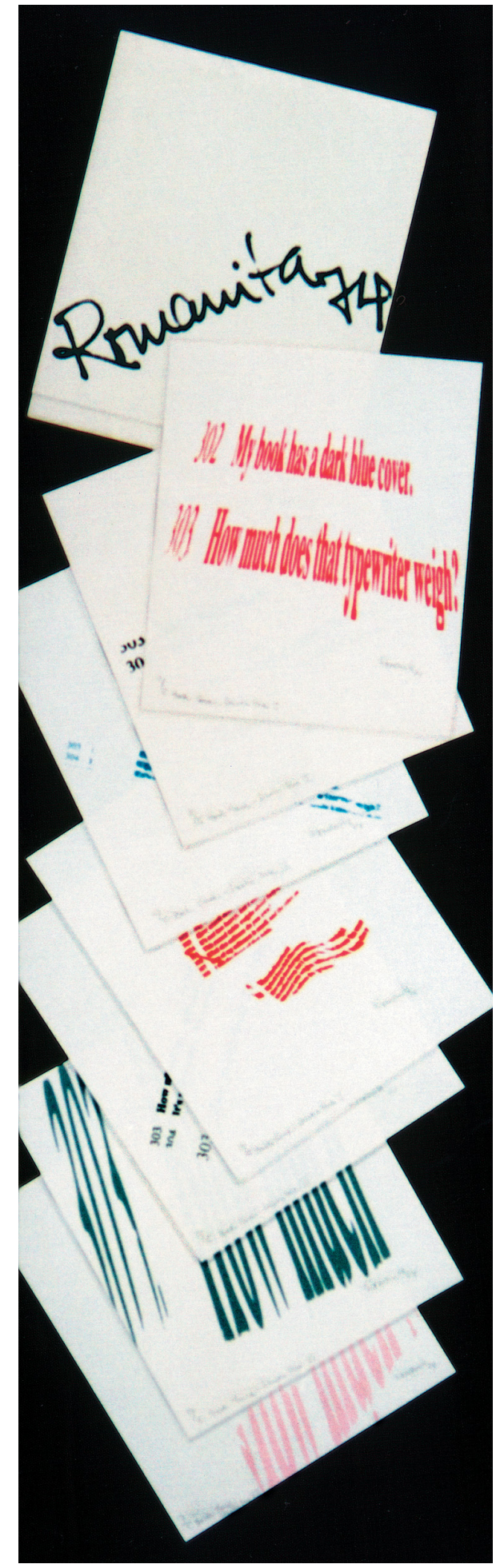

Romanita Disconzi, portfólio de 1974. 
álbum implica ser um livro. A principal queixa poderá ser (ou efetivamente será) a distância formal ao objeto livro. O fato é que um livro de artista raramente se parece com um livro. Normalmente é um livreto, um caderno, um carnê, um prospecto... $\mathrm{A}$ mimese, quando existe, é da ordem do jogo. Tecnicamente, um livro tem um número mínimo de páginas, ao redor das cinquenta, dependendo do país (terá, em média, um múltiplo de oito ou dezesseis, como 48). Devem estar unidas por um dos lados, possuir uma capa fixada ao miolo, etc. Mas mesmo que pareça apressado, pode-se repetir que se é um álbum, então é um livro. O que não significa justificar uma cômoda apresentação, mas sim compreendê-la.

Veja-se a caixinha de gravuras de $\mathrm{Ru}-$ bem Grilo, Xilogravuras 1998, no formato $12,5 \times 18,5 \times 2 \mathrm{~cm}$. Abrindo a caixa, temos o livreto Objetos imaturos, mais duas sanfonas de três vincos cada, mais oito gravuras em folhas soltas, mais seis gravuras maiores dobradas in-oitavo, além de uma folha com os dados técnicos e biográficos. ${ }^{29}$ Tem-se a sensação de ter-se adquirido um minitesouro, um bauzinho de gravuras liliputianas que se multiplicam nas suas possibilidades de apresentação. Essa noção de precioso é inerente ao produto da atividade manual artística, mesmo que as obras de Grilo pareçam prosaicas, ou, individualmente, ingênuas. Mas não é assim. Xilogravuras não é composto por gravuras reais, mas sim por fac-símiles em offset. Seu propósito explícito é a divulgação. De nada serve seu trabalho ficar nas gavetas (que, por sinal,

${ }^{29}$ É possível que esses números variem, por falhas de acabamento. No exemplar consultado, existe uma gravurinha a mais, repetida.

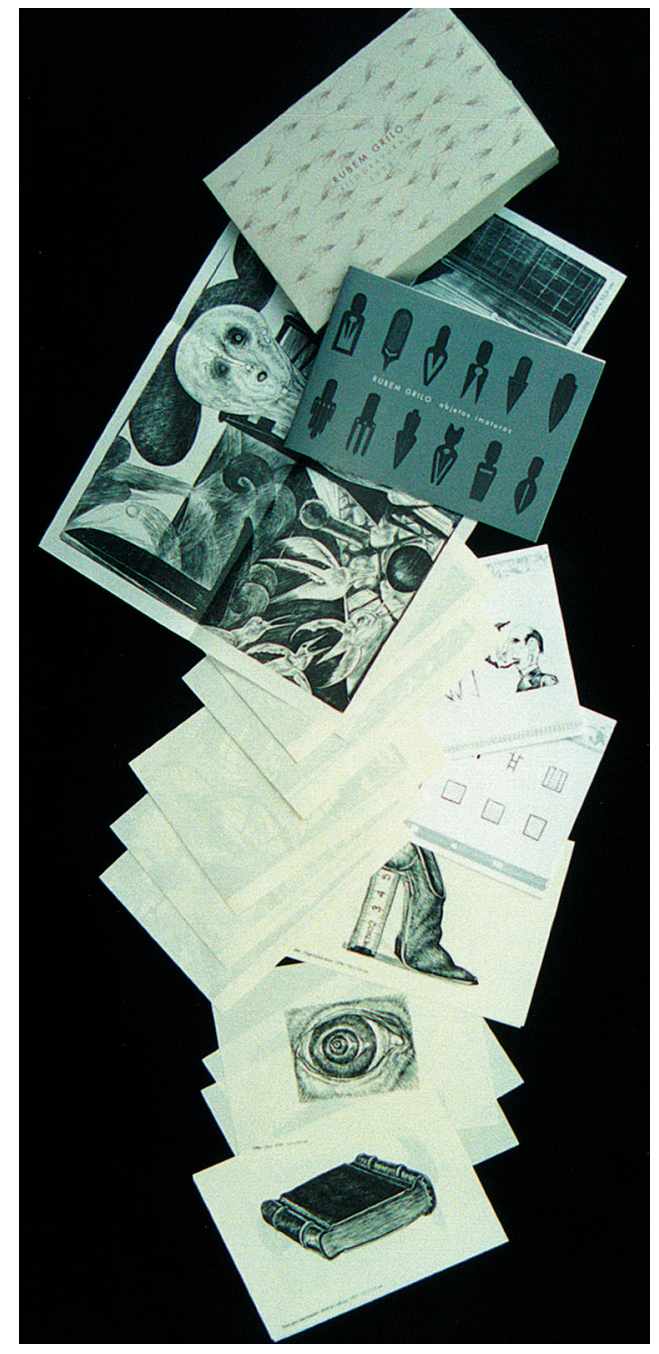

Rubem Grilo, Xilogravuras, 1998.

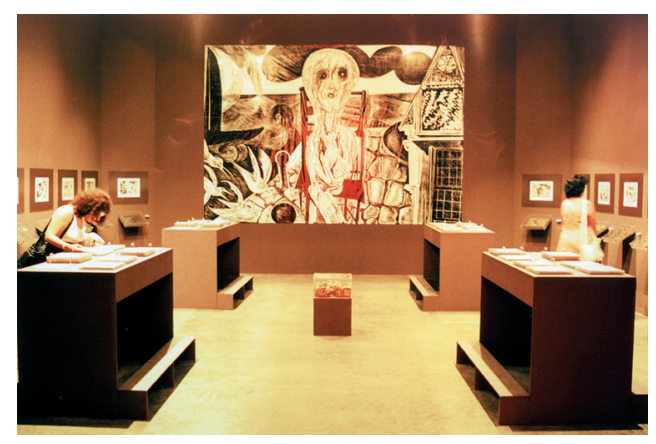

Rubem Grilo, sala especial na XXIV Bienal de São Paulo, 1998. 
devem ser centenas). A obra visual deve ser mostrada, quando não pode ser comida. $\mathrm{E}$ Grilo sabe disso, basta lembrar o impressionante espaço negro ocupado na XXIV Bienal de São Paulo, 1998, com vitrinas e displays repletos de centenas (ou milhares) de gravurinhas e matrizes, além das mesas com grandes livros com páginas de duplo acrílico, com as xilos entre elas, como mariposas aprisionadas. Ele conhece muito bem a mídia, até porque ele trabalhou dezessete anos na imprensa, desenhando fortes caricaturas políticas. ${ }^{30}$

A intenção do artista, aliada ou não à necessidade do mercado, pode ter a decisão estratégica da agregação, da coleção, como na obra precedente. Mas o dia-a-dia das relações entre agentes e instituições pode tender à desagregação das partes. Desconheço que exista estatística que indique quantos álbuns foram desmanchados para que as unidades que os compunham fossem comercializadas ou distribuídas como gravuras individuais. Não é admissível que persista a incompreensão a esse respeito, principalmente se isso comprometer a integridade do trabalho museológico. Luzes foram apontadas nesse sentido por Cristina Freire em pesquisa sobre obras e documentos de arte conceitual abrigados no acervo e na biblioteca do Museu de Arte Contemporânea da Universidade de São Paulo. Em Poéticas do processo: arte conceitual no museu, comentando a influência da flutuação de valor no destino institucional da obra de arte, ela exemplifica com Codices Madrid, de Joseph Beuys.

${ }^{30}$ Atelier: guia de artes plásticas, ano II, n. 22, março de 1999, p.3.
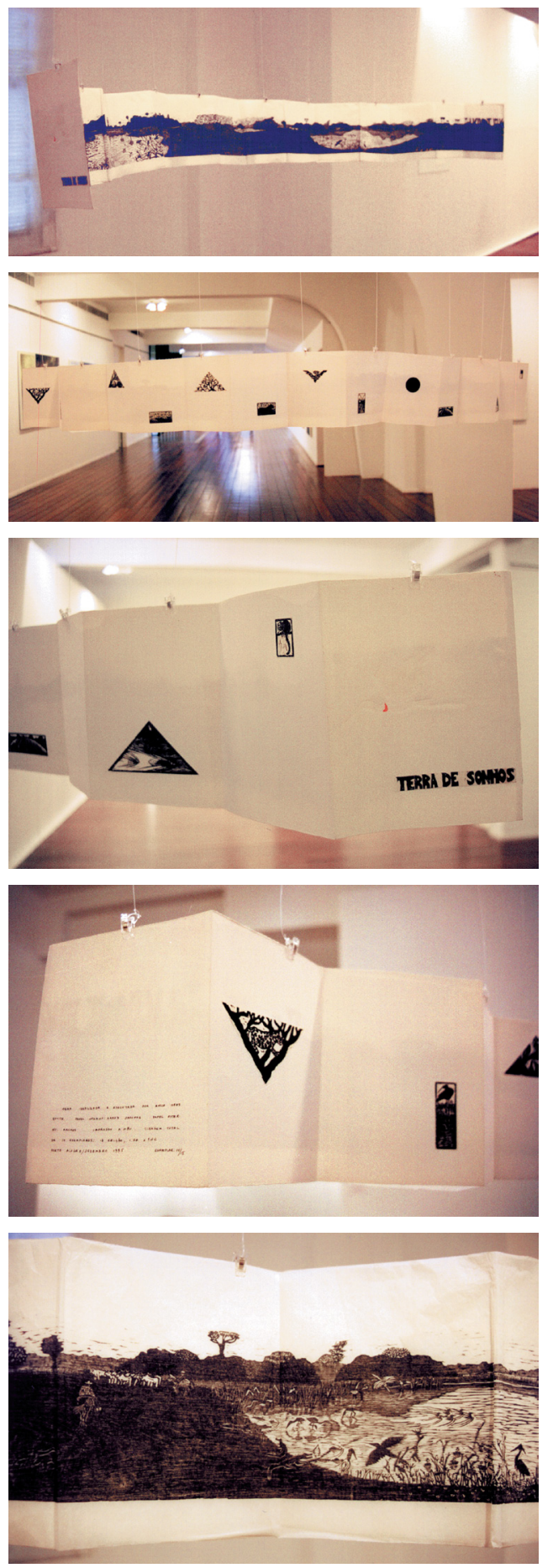

Anico Herskovits, Terra de sonhos, 1995, em exposição de 1999 na Galeria Sotero Cosme, Museu de Arte Contemporânea do Rio Grande do Sul (em implantação), Porto Alegre. 
As litografias em questão originaram-se de uma sequência de esboços do artista surgida em 1974/1975 por ocasião da publicação dos Codices Madrid, obra homônima de Leonardo da Vinci [...]. Respeitando seu formato original, a série foi editada como livro de esboços. Em outras palavras, um livro de artista com autorização de Beuys, numa tiragem de 1000 exemplares. Aqui não é a unicidade que confere a aura à obra, mas o nome do artista. Originalmente produzido como livro de artista, posteriormente, desmembrado prancha a prancha, as 62 litografias integram a coleção e o catálogo do MAC-USP desde a doação pelo Consulado Alemão, após sua exibição na XV Bienal Internacional de São Paulo (1979). (Freire, 1999, p.37)

Esse exemplo de propensão ao espetáculo, que qualifica obras múltiplas como únicas é pontual no caso dos museus de arte contemporânea, cada vez mais preparados para guardar obras efêmeras. O MAC tem seus livros íntegros, e ao co-editar a pesquisa de Freire promoveu a mais importante contribuição à museologia brasileira dos últimos anos.

Principalmente quando se está falando no sentido genérico, o usual é que o livro de artista se imponha por sua eloquência física, como já sabemos, mais do que pelo eventual texto que possa ocorrer. A aparência ao olhar é sua primeira apresentação, aos outros sentidos num segundo momento e a leitura, se houver, por fim. Volto ao passado e recorro a uma obra já muito comentada, para a qual não faltam argumentos. Tomo como exemplo La Prose du Transsibérien et de la petite Jehanne de France, um trabalho grandiloquente.

É uma obra de parceria entre Sonia Delaunay-Terk (1885-1979) e Blaise Cendrars (1887-1961), publicada em Paris em 1913.É uma sanfona com uma grande dobra longitudinal central, e depois dobrada transversalmente 21 vezes, acondicionada em uma pequena
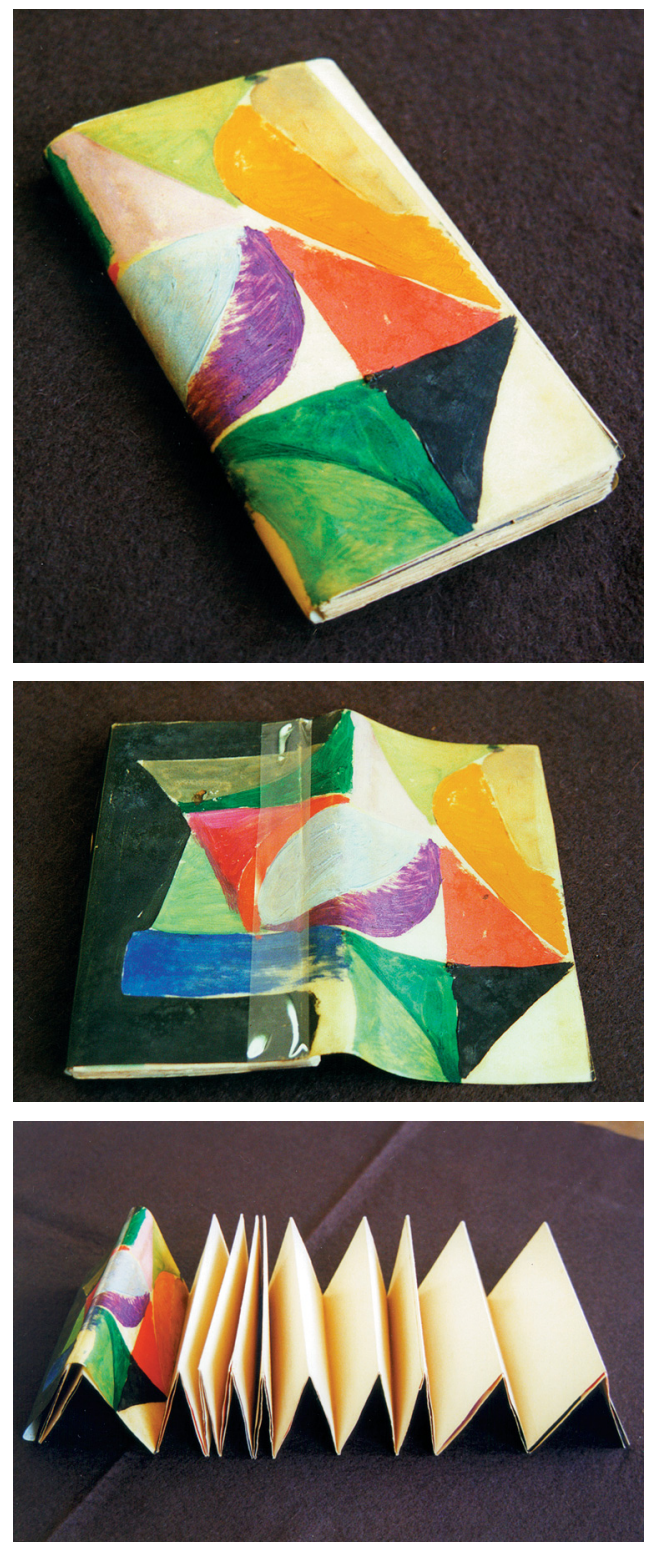

Sonia Delaunay-Terk e Blaise Cendrars, La Prose du Transsibérien et de la petite Jehanne de France, 1913

(Biblioteca Mário de Andrade, São Paulo). 
capa de pergaminho. Dobrada, é pequena como qualquer mapa turístico ou carta de percurso ferroviário. Totalmente aberta, ultrapassa os dois metros de comprimento. De alto a baixo, o lado direito é ocupado pela poesia de Cendrars e o lado esquerdo, pela gravura (pochoir) de Delaunay-Terk, que também avança por entre o texto, num exercício de cores vibrantes, luminosas.

É impossível não ficar encantado com esse trabalho, considerado por seus autores como o primeiro livro simultâneo. Castleman (1994), embora trate dessa obra com o mesmo distanciamento crítico aplicado a outros trabalhos, elegeu-a como a ilustração de fundo da capa de seu livro (a reprodução é dos seguimentos finais, um pouco menor que o tamanho natural). Noëlle Batt (Proudon, 1997, p.23-34) comenta, "por prazer", $L a$ Prose... para demonstrar sua conceituação de livro de artista (no artigo "Le livre d'artiste, une oeuvre emergente"). Pierre Cabanne (também em Proudon, em intervenção para o debate Rencontre 1 - Peindre les mots ou le livre d'artiste, p.340) destaca La Prose... juntamente com La Boite en valise, 1938, de Marcel Duchamp, como momentos ímpares da história do livre de peintre e do livro-objeto, pelo pitoresco e pelo insólito.

Descrições enternecidas da obra de Sonia Delaunay e Cendrars são usuais. Veja-se, também, o encantamento renovado
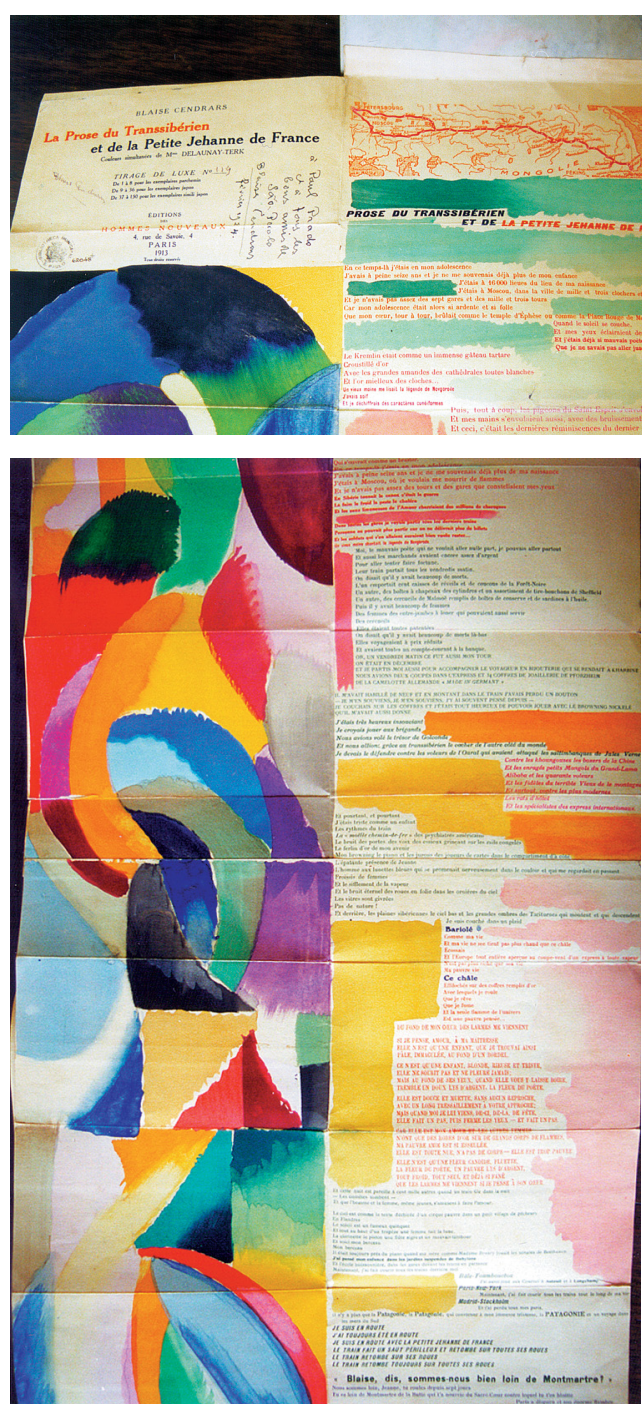

Sonia Delaunay-Terk e Blaise Cendrars, La Prose du Transsibérien et de la petite Jehanne de France, 1913

(Biblioteca Mário de Andrade, São Paulo). de Judith Hoffberg, na revista Umbrella (dezembro de 1998, p.116), em decorrência do comentário sobre a exposição Master Drawings from the Hermitage and Pushkin Museums, em Nova York.

Mesmo nessa impressiva mostra de desenhos dos velhos mestres, La Prose du Transsibérien et de la petite Jeanne de France, um livro em sanfona escrito por Blaise Cendrars e Sonia Delaunay em 1913, se sobressai. Se você conhece essa obra apenas de reproduções, então você ainda não o enxergou. Na Morgan ele está lindamente disposto de modo que se pode vê-lo do outro lado do recinto como se fosse uma pintura elegantemente equilibrada, uma das pinturas simultaneístas de Robert Delaunay, por exemplo. De perto, é mais como cubo-futurismo: se você já esteve 


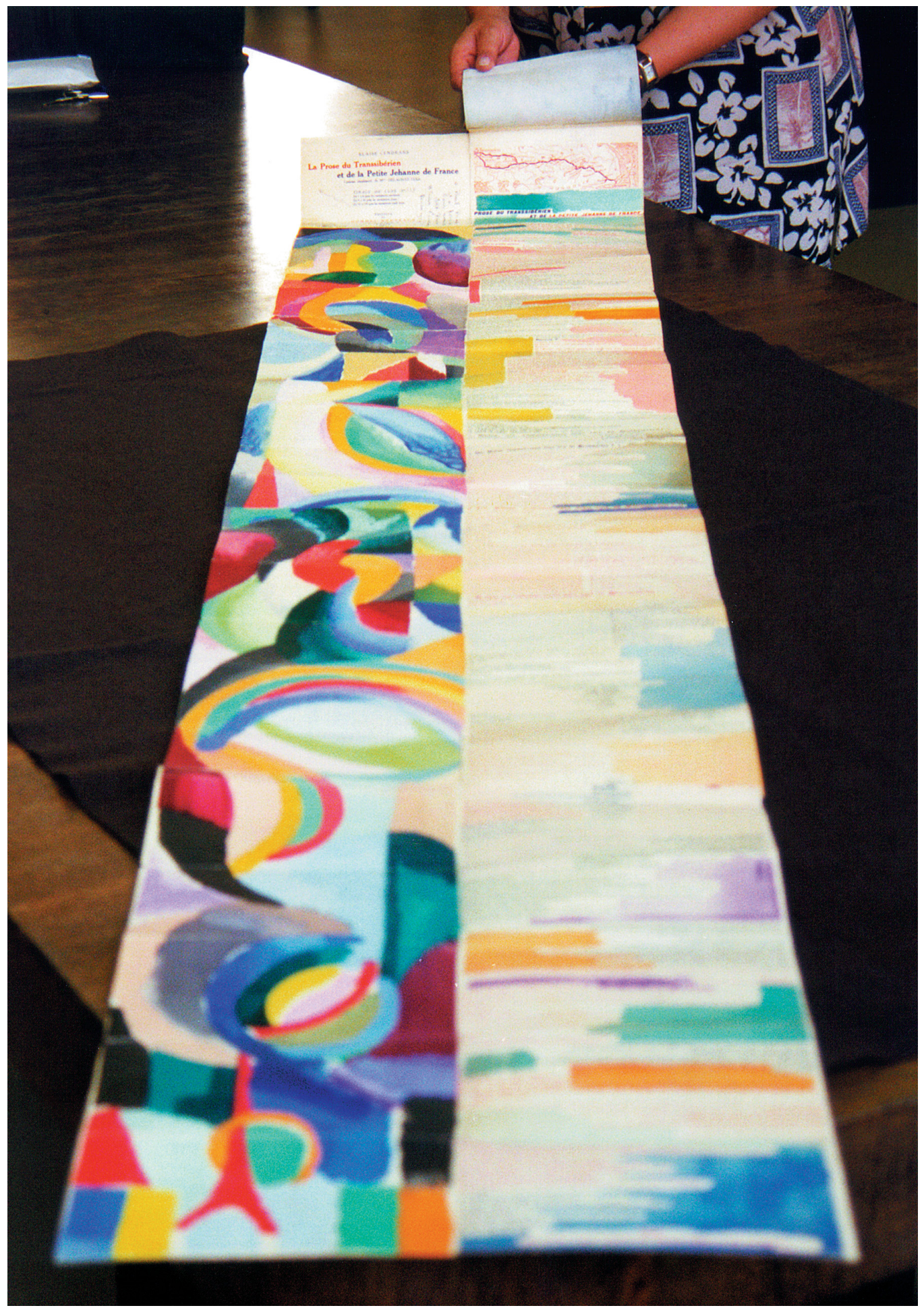

Sonia Delaunay-Terk e Blaise Cendrars, La Prose du Transsibérien et de la petite Jehanne de France, 1913 (Biblioteca Mário de Andrade, São Paulo). 
num trem cortando a zona rural russa no meio da noite, com grandes fachos de luz batendo intermitentemente dentro de seu compartimento escuro, é sobre isso que é esse livro. As cores em pochoir de Sonia Delaunay interagem com os tipos multicoloridos do poema de Cendrars com um efeito maravilhoso, delicado. O efeito do pochoir é de fato mais próximo da aquarela em sua liberdade, e existem passagens de, digamos, pincelada vermelha sobre tipo rosa, cuja textura nenhuma reprodução pode transmitir. Se você ama livros, não perca esse.

Parece-me que pode ser determinado um paradoxo em La Prose... Apesar de ser uma obra de colaboração - e sem, absolutamente, desmerecer o trabalho de Cendrars -, sua fisicalidade, bem como a aparência dessa fisicalidade prescindem do texto escrito. A visualidade, sim, é o texto. Não haveria maior prejuízo para sua condição de livro-objeto se as palavras fossem suprimidas, ou obliteradas, ou substituídas por quaisquer abstrações lineares. Como na apropriação homônima do poema de Mallarmé, Un Coup de dés jamais n'abolira le hasard, por Marcel Broodthaers, 1969, em cem cópias em papel transparente onde estão apenas linhas negras de tamanhos e espessuras correspondentes aos versos originais, que confirma o caráter objetual de sua concepção.

Esse entusiasmo pelo belo revelaria uma possível defesa de gostos e valores já consagrados? É possível. Dificilmente La Prose... será definido como livro de artista no sentido estrito, sem que restem dúvidas. Mais fácil permanecer com a aura de ser uma das obras-primas do livro-objeto. Categoria essa que irá abrigar justamente os maiores experimentos de desconstrução.

\section{Fronteiras com o livro e a literatura}

$[\ldots]$

Os livros são objetos transcendentes

Mas podemos amá-los do amor táctil

Que votamos aos maços de cigarro

Domá-los, cultivá-los em aquários,

Em estantes, gaiolas, em fogueiras

Ou lançá-los pra fora das janelas

(Talvez isso nos livre de lançarmo-nos)

$\mathrm{Ou}$ - o que é muito pior - por odiarmo-los

Podemos simplesmente escrever um:

Encher de vãs palavras muitas páginas

E de mais confusão as prateleiras.

[...]

Esses versos são um trecho da canção Livros, de Caetano Veloso, comentada a algumas páginas atrás. Sua leitura é uma possibilidade de passagem para esse segmento, que abandona as referências diretas à divulgação e passa para as trocas com o livro e a literatura. E prossigo pelo mote do furo.

Especialmente a tatilidade lúdica do livro-objeto utilizou o orifício como expediente de deslocamento da atenção perceptiva, controlado ou não. A interação entre 
a emoção da descoberta de um novo caminho espacial e a lembrança do evento no tempo são por si sós fonte de desfrute estético. Para explicar melhor, proponho um segundo "cafezinho poético". Gostaria de ilustrar com palavras ao invés de imagens, usando o artifício do verso e da leitura linear como intermediário da emoção visual, já que estamos circulando sobre fronteiras. Paulo Bruscky, em um artigo para O galo, de Pernambuco, maio de 1998, propôs essa emoção através do poema "A escultura folheada", do arquiteto e poeta Joaquim Cardoso (1897-1978). Por ter

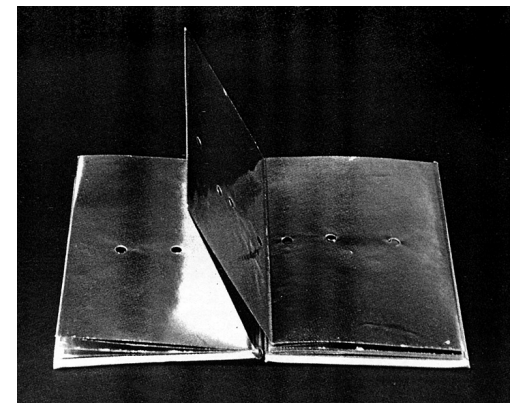

Lucio Fontana, Concetto spaziale, 1966 (Bentivoglio, 1990, p.16). um desenvolvimento especialmente agradável, o transcrevo integralmente. ${ }^{31}$

Aqui está um livro

Um livro de gravuras coloridas;

Na parte superior da capa deste livro

Há um ponto-furo: um simples ponto

E nada mais. simples furo

Abro a capa do livro e

Vejo por trás da mesma que o furo continua;

Folheio as páginas, uma a uma.

- Vou passando as folhas, devagar, o furo continua.

Noto que, de repente, o furo vai se alargando

Se abrindo, florindo, emprenhando,

Compondo um volume vazio, irregular, interior e conexo:

Superpostas aberturas recortadas nas folhas do livro.

Têm a forma rara de uma escultura vazia e fechada,

Uma variedade, uma escultura guardada dentro de um livro,

Escultura de nada: ou ainda, de um pseudo-não;

Fechada, escondida, para todos os que não quiserem

Folhear o livro.

Mas, prossigo desfolhando:

Agora a forma vai de novo se estreitando

Se afunilando, se reduzindo, desaparecendo/surgindo.

E na capa do outro lado se tornando novamente

Um ponto-furo, um simples ponto

E nada mais. simples furo

\footnotetext{
${ }^{31}$ Citado por Bruscky, 1998, e originalmente publicado no livro Poesias, Rio de Janeiro: Editora Civilização Brasileira, 1971.
} 
Os seres que o construíram, simples formigas aladas,

Evoluíam sob o sol de uma lâmpada

Onde perderam as asas. Caíram.

As linhas de voo, incertas e belas, aluíram;

Mas essas linhas volantes, a princípio, foram

Se reproduzindo nas folhas do livro, compondo desenhos

De fazer inveja aos mais "sábios artistas".

Circunvagueando, indecisas nas primeiras páginas,

À procura da forma formante e formada.

Seus voos transcritos, "refletidos" nessas primeiras linhas,

Enfim se aprofundam, se avolumam no vazio

De uma escultura escondida, no escuro do interno;

Somente visível, "de fora", por dois pontos;

Dois pontos-furos: simples pontos

E nada mais.

simples furos

$\mathrm{Na}$ canção de Caetano Veloso que "vimos" há pouco, o livro flana entre uma concepção universal, arqueológica e histórica, e uma concepção pessoal, fantástica e poética. Ainda assim, a dimensão pessoal está mais projetada na forma de redação da canção do que no seu objeto de afeto. O livro de Caetano permanece atrelado a personificações animistas dentro de uma elaboração mágica. O livro de Caetano é "o" livro. No poema de Joaquim Cardoso, o livro é concreto e possui sua inserção no tempo presente da poesia. Ele existe, e é algo. Talvez como um atlas, que é um objeto livro que traz pela codificação gráfica a realidade do fato (e daí o seu particular encanto). O livro de Cardoso é aquele livro que ele possui, e está na prateleira. Ele é apenas "um” livro. Mas a apresentação de ambos é cúmplice da fisicalidade e da espacialidade, mesmo que volátil. Eles permitem o tato e, se pudessem, permitiriam a gustação. Caetano e Cardoso, o primeiro pelas palavras no plural e o segundo pelo singular da imagem espacial, demonstram a imensidão da ternura universal pelo livro.

A partir do prazer sugerido pelo exercício de visualização, podemos separar as possibilidades de intervenção na página em dois grupos, definidos pela maior ou menor proximidade do estímulo visual bidimensional ou do estímulo tátil. A página pode sofrer intervenções gráficas e intervenções plásticas. Naturalmente existe um universo de intervenções intermediárias ou compostas, assim como intervenções exteriores, ambientais e circunstanciais. Faço uma redução, mas é útil como modelo.

As intervenções gráficas mais importantes para o modelo que se tem hoje de um volume estão localizadas no renascimento. Aldo Manuzio, o Velho (ou Aldo Manunzio, ou Aldus Manutius), tipógrafo italiano (1449?-1515), revolucionou a página do livro com os textos elaborados em manchas não retangulares de Hypnerotomachia Poliphili (ou Luta do amor em sonho de Polifilo, 1499, do monge dominicano Francesco Colonna) e o desenho de caracteres tipográficos com a tipologia usada em De Aetna (Sobre 
o Etna, 1495, do cardeal Pietro Bembo), além de em 1500 ter criado o tipo inclinado que passou a ser chamado itálico (gravado para ele pelo ourives Francesco Griffo, daí também a designação grifo). Aldo é um expoente da editoração humanista do renascimento, que estabeleceria o princípio da diferenciação formal entre a obra impressa e o manuscrito, ajudando a firmar o conceito de disciplina editorial. Nesse sentido, sua obra é mais importante do que a de Gutenberg, visualmente devedora dos manuscritos medievais (a Bíblia de 42 linhas, 14521455 , por exemplo).

As pequenas revoluções da página somente teriam um novo grande impulso através de criadores fascinados com os ideais de Mallarmé e seu poema de 1847, Um lance de dados jamais aboliráo acaso. Esse impulso envolveria tanto o projeto gráfico como a literatura, na medida em que propunha novas dimensões de leitura. Mallarmé se colocaria como "ponto-encruzilhada em todo o longo processo de desenvolvimento da linguagem verbal, situando-se também como desafiador dos sistemas tradicionais de ler e da concepção secularmente inamovível do livro" (Roberto Pontual, 1971, p.197).

Octavio Paz considera que Un coup de dès é o apogeu da página como espaço literário, ao mesmo tempo que inauguraria outro espaço.

O poema deixa de ser uma sucessão linear e escapa assim da tirania tipográfica que nos impõem uma visão longitudinal do mundo, como se as imagens e as coisas se apresentassem umas depois das outras e não, como realmente acontece, em momentos simultâneos e em diferentes zonas de um mesmo espaço ou em diferentes espaços. (Paz, 1965, p.43)

Paz identifica em Mallarmé o legado maior do que a palavra: a abertura do espaço. A página nada mais seria do que "a representação do espaço real de onde se desenvolve a palavra”. Entre a página e a escrita se estabeleceria uma relação nova no Ocidente. "O espaço se torna escrita: os brancos que representam o silêncio, e talvez por isso mesmo, dizem algo que não dizem os signos" (p.63).

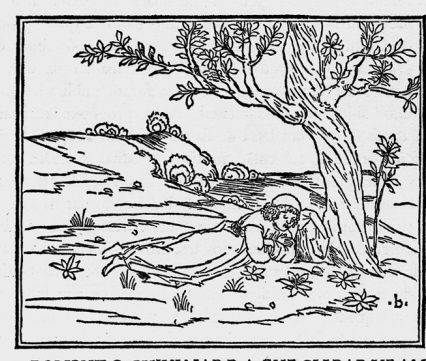

POLIPHILO QVIVI NARRA,CHE GLIPARVEAN, CORA DI DORMIRE,ET ALTRONDE IN SOMNO RITROVARSE INVNA CONVALLE,LAOVALENEL FINEER A SER ATADEVNA MIR ABILECLAVSVRA CVM VNA PORTENTOSA PYRAMIDE,DE ADMI, SOPR A.LAQVALE CVM DILIGENTIA ET PIACERE SVBTILMENTE LA CONSIDEROE.

STIG, A SPAVENTEVOLE SILVA,ET CONSTIR 1 . pato Nemoreeuafo, \&gli primialtri lochi per el dolce

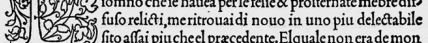

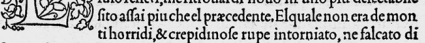
frumofi iugi. Ma compofitamente de grate montagniole dinontropo altecia. Siluofe di giouani quercioi, di roburi, fraxini \& Carpini, \& di frondofi Efculi, \& llice, \& diteneri Coryli,\&di Alni,\&diTi,
lie,\& di Opio, \& de infructuofi Oleafri, difpofiti fecondo lafpectode gli arboriferi Colli, Et giu al piano erano grate filuule dialtri fluatici

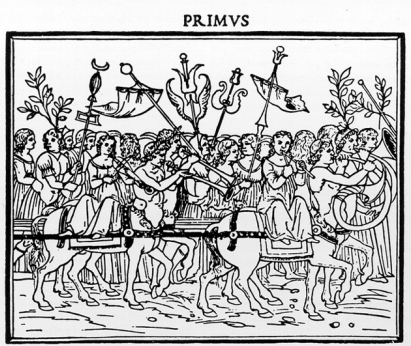

EL SEQVENTE triúpho nómeno miraucgliofo all primo.Imp checgli hauea le qutro uolubile rotetutte, \& gli radii, \&il meditullo defu feo achate, di cádide uéule uagaméte uaricato. Netale certańte geftoere Pyrrho cú le noue Mufe \& A polline imedio pulfäte dalla anatura ip̈ffo. Laxide \&la forma del diatoo ğleel primo,ma le tabelleeráo di cyance Saphyro orientale,atomato de cintilluledoro, all a magica gratifimo,
\&longo acceptifimo a cupidine nella finiftra mano. Nella tabella dextra mirai exf́calpto una infigne Matrōa che dui oui hauca parturito, in uno cubile regio colloca
ding 12, id ufate, \& multe altre matrone \& a ftante NympheDegli quali ufciuade unouna flammula, \&delalo
tro ouodue fpectatifi me ouodue rpectaifle.
me fille me telle.

Aldo Manuzio, o Velho, manchas de Hypnerotomachia Poliphili, 1499

(McMurtie, 1982, p.228; Satué, 1993 p.39). 

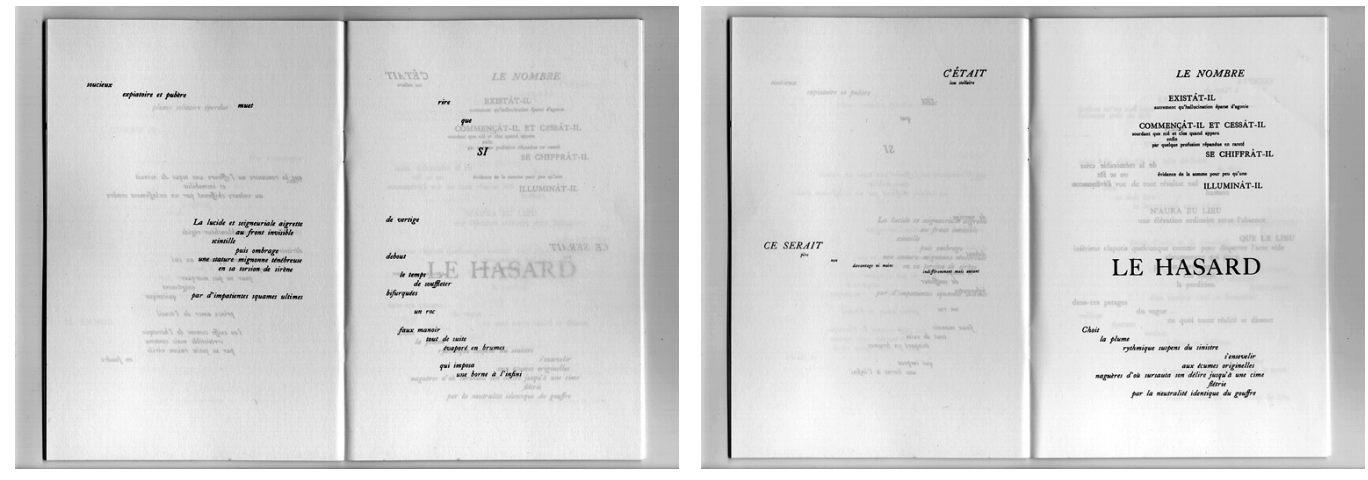

Stéphane Mallarmé,

Un coup de dés jamais n'abolira le hasard, 1896.

(Páginas reproduzidas em encarte de Campos, Pignatari e Campos, 1991.)

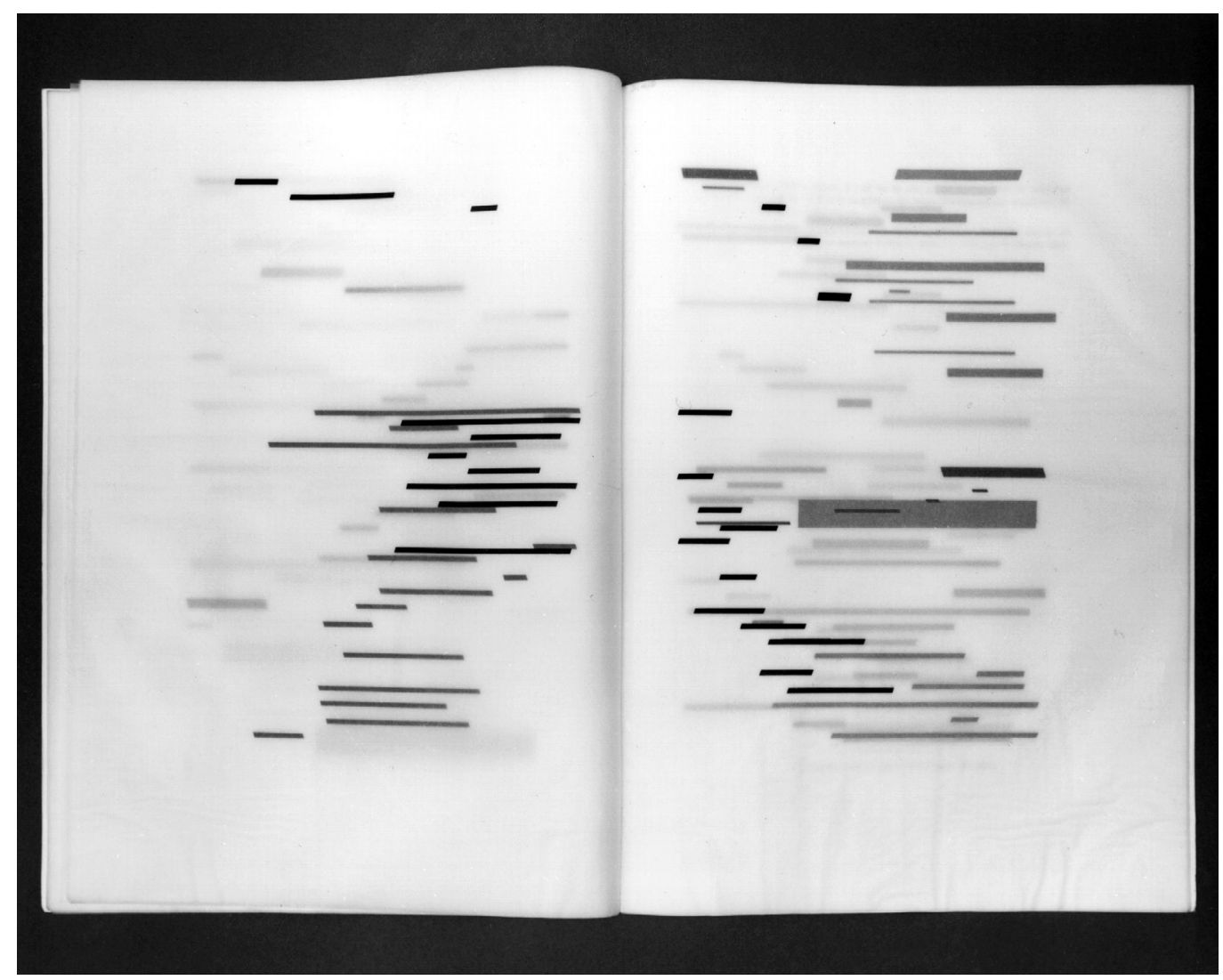

Marcel Broodthaers, Un coup de dés jamais n'abolira le hasard, 1969. Imagem cedida pelo Museum of Modern Art, Nova York. 
Para Paz, uma das melhores análises sobre Um lance de dados... seria o ensaio de Maurice Blanchot, Le livre à venir, 1959. Nele Blanchot ressalta as entidades manipuladas pelo poema. Como o entendimento do espaço:

Está aqui, sabemos, a grande inovação de que se orgulhava Mallarmé. Pela primeira vez o espaço interior do pensamento e da linguagem é representado de uma maneira palpável. A "distância... que mentalmente separa os grupos de palavras ou as palavras entre si" está visível tipograficamente, assim como a importância de certos termos, sua força de afirmação, a aceleração de suas ligações, sua concentração, sua distribuição, enfim a reprodução, por intermédio das palavras e de seus ritmos, do objeto que ambos designam.

Ou a consciência do tempo:

O tempo da obra não é tomado por empréstimo ao nosso, objetivo ou subjetivo. Formado por ela, pertence à obra em si, que é a menos imóvel possível de se conceber. E dizer o tempo, como se nos referíssemos apenas a uma maneira de durar, é desconhecer o enigma essencial deste livro e sua inexaurível força de atração.

\section{E a leitura como uma operação:}

A obra literária ali está em suspenso entre sua presença visível e sua presença lisível: partitura ou quadro que se precisa ler e poema que se deve ver e, graças a esta alternância oscilante, buscando enriquecer a leitura analítica pela visão global e simultânea, enriquecer também a visão estática pelo dinamismo do jogo de movimentos, buscando enfim se estabelecer no ponto de interseção onde captar é ver e ler, mas também se estabelecendo no ponto onde, não se tendo processado a ligação, o poema ocupa apenas o vazio central que representa $o$ porvir de exceção. (Blanchot, 27 ago. 1960, p.7)

A intervenção na página através da conformação do texto na sua relação com o espaço branco é a mais evidente solução de continuidade com a revolução gráfica e poética de Stéphane Mallarmé. Prossegue com o construtivismo eslavo, por um lado, com os futuristas e dadas, por outro, continuando até o letrismo e as diversas manifestações de poesia visual. Eugen Gomringer lembrou que "a escrita é linguagem visível" e que a poesia visual (em que os mal-entendidos são frequentes) não é exclusivamente visual (Kostelanetz, 1979, p.153-154). Na prática, a influência do branco gráfico no mundo da literatura foi efetivada através da poesia visual e concreta. Isso propiciou toda uma vertente de criações de dois mundos, das letras e das artes. Ao organizar uma mostra internacional de poesia em São Paulo, Philadelpho Menezes utilizou um esquema que separa as obras em três grupos: 1) poemas em que a visualidade está na forma gráfica da palavra (grupo que inclui o poema concreto, entre outros);2) poemas em que a visualidade está em formas gráficas alheias à palavra (com boa difusão, graças à poesia visiva italiana); e 3) poemas em que a visualidade está em formas gráficas integradas à palavra (Menezes, p.39 e seguintes). $\mathrm{O}$ produto desses movimentos teve boa divulgação por ser reproduzível em veículos alternativos, como em suplementos literários de periódicos, em cartazes e cartazetes, em prospectos, na arte postal, depois somando aos meios gráficos os eletrônicos, como o videotexto e a vídeo-arte. Mas sobretudo pela possibilidade de utilização em suporte impresso é que o poema visual dá sua parcela de contribuição ao desenvolvimento da arte em livro. Às vezes 
mal acomodado no códice convencional, o poema visual se queria apresentado em páginas soltas, ou em construções de montar, ou em objetos lúdicos. O livro de artista vem, nesse momento, ser o corpo que transporta a adição ou a interação do signo verbal com outros códigos agregados.

Esse é o centro geográfico "oficial" entre a arte e a literatura. Para o livro de artista brasileiro é um momento de afirmação, pois dele partiram nossas maiores contribuições para o gênero. Especialmente a poesia concreta, instrumentalizada pela arte concreta e pelos movimentos europeus do início do século (anos 10 e 20), iria possibilitar a participação do País em muitos grandes e pequenos eventos internacionais. Menezes lembra que a poesia concreta é a última experimentação visual "centrada na predominância da palavra sobre os outros códigos", sendo caracterizada "pelo tom agonístico, provocativo e polêmico, pelos princípios programáticos exibidos em

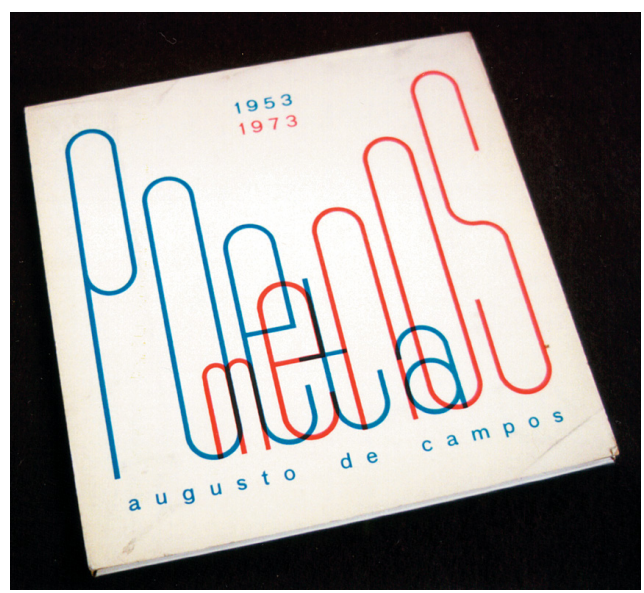
mostras e manifestações, pela utopia da renovação pela estética que se funde todo o tempo com uma índole totalitária, pelo teor otimista e messiânico de certas posturas" (p.40-41).

Para Moacy Cirne (1975, p.34 e 35), o livro retomaria “o questionar levado a cabo por certas vanguardas culturais", e nessa retomada, caberia ao poeta experimental ter as condições necessárias para o aporte ao livro pelo seu conhecimento das práticas semiológicas.

Desde os inícios da poesia concreta os dois pólos (vanguarda - objeto/livro) interpenetram-se, e ao se interpenetrarem dirigem-se com maior possibilidade de eficácia para os questionamentos e as transgressões que levam o experimentalismo estético à aproximação da ciência, sem que esse fato (de ordem cultural) caia no abstrato ou no metafísico.

A poesia visual, por outro lado, foi uma experimentação da visualidade para fora do texto, a partir de confrontos semânticos entre palavra e imagem, intervindo no mundo da comunicação de massa. Dentre os caminhos que tomou está o do poema-processo brasileiro, lançado em 1967 e de curta duração, rompido inclusive com a poesia concreta, valorizando ao extremo o aspecto visual como elemento primordial da obra. Philadelpho Menezes chama de esquálidos os poemas-processo mais ortodoxos, "que nos anos 60 procuraram não apenas criar a poesia sem palavra mas, principalmente, a poesia sem a natureza da palavra, ou seja, sem o aspecto simbólico, conceitual, semântico que toda comunicação 
poética contém, ainda que alterado pela sua iconização relativa" (p.47). Entre seus representantes estavam Wlademir Dias Pino, Moacy Cirne e Álvaro de Sá. Neide Dias de Sá prossegue utilizando seus livros-poema em intercâmbio com sua pintura geométrica. Também para ela (em conversa informal), $A$ ave, 1956, de Dias Pino, é o primeiro livro-objeto entendido como tal do Brasil. Seu caráter precursor também foi apontado por Annateresa Fabris (1988).

A ave inova em vários níveis. A estrutura física do livro é parte integrante do poema, pois ele só existe a partir da manipulação criadora do fruidor, que determina o ritmo da leitura, suas possibilidades de decodificação, as relações espaciais entre página e página, a separação, desejada pelo autor, entre a escrita e a leitura. A fusão de gráficos, palavras, transparências, perfurações cria um código espacial, no qual as informações se superpõem e se particularizam num jogo de remissões que multiplica os significados verbais e visuais, que transforma o poema numa estrutura perceptiva constantemente ressemantizada, numa "armadilha visual", que obedece a uma lógica interna, autorreferencial.

A reexperimentação internacional e a experimentação brasileira intensa nos anos 50 e 60 das unidades fonéticas ou verbais,
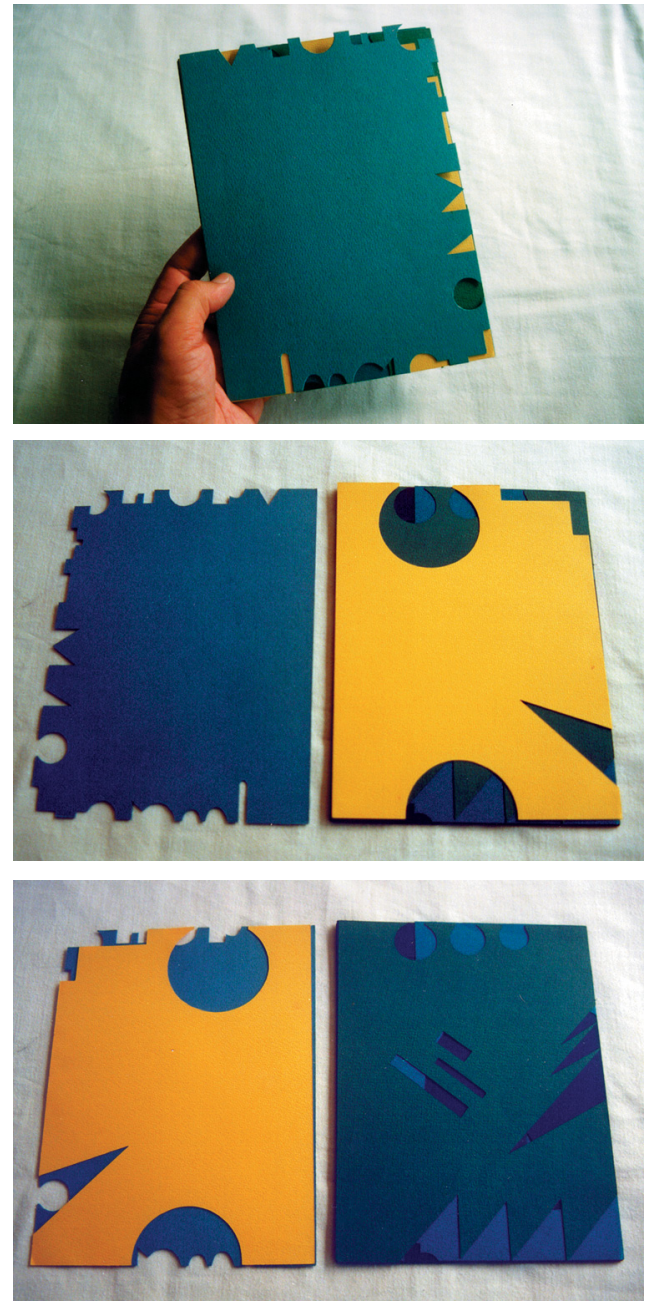

Alvaro de Sá, Alfaberto, 1966 (segunda versão). e sua resultante tendência à visualidade, acabaram por receber mais atenção do escopo da literatura. Os estudos em artes mantiveram sua reticência, voluntária ou involuntariamente concordando com os latifúndios culturais e de pesquisa. A produção intelectual foi quase sempre periférica, e ainda hoje percebo muxoxos em relação a ela. Como há alguns anos, quando pedi a intermediação de um ex-diretor da editora onde trabalho para um empréstimo da Caixa preta (de Augusto de Campos e Julio Plaza), propriedade de um professor local de literatura. Com sua ironia característica e bom humor ele telefonou ao professor perguntando se ele possuía "aqueles livros de criança, que saltam molinhas e cobrinhas de dentro". $\mathrm{Na}$ época eu me senti incompreendido. Hoje acho engraçado.

Como etapa da instauração do livro de artista em geral e do livro-objeto em particular, a poesia visual é particularmente significativa, na medida em que, de 
dentro de sua própria experimentação, dirige a contemplação da unidade celular da palavra para a "inteiridade" do corpo do objeto gráfico. Um pouco disso pode ser depreendido de um prefácio de Paul Zelevansky, intitulado "Why is this book different from all other books?" (Kostelanetz, 1979, p.162-163).

Nós pedimos que você aceite as margens da página como você aceita o proscênio que contém a peça. Ambos são lugares de ação, naves da história, e o tempo passa dentro de seu próprio compasso. É importante lembrar que nós podemos passar livremente dentro ou fora do espaço, já que a separação é porosa entre nós [...] Não é uma maravilha que possamos construir ou destruir tais fronteiras livremente? [...] $\mathrm{O}$ espaço acima do livro contém encantamento e exílio. [...] Onde tudo é visível, tudo é manifesto, tudo é simultâneo no pensamento. Palavras estão dentro das imagens, imagens estão dentro das palavras, e ambas falam umas das outras simultaneamente e à parte. Do intercâmbio vêm o veículo e a forma: a tela de projeção, o piso de reflexão, a superfície, a página.

A escrita tipográfica (construída com caracteres mecânicos) pôde, de fato, abandonar a monotonia marcial da página impressa convencional e somar-se às diversas vanguardas artísticas. Isso era natural, já que a tecnologia o permitiu. Como tam-

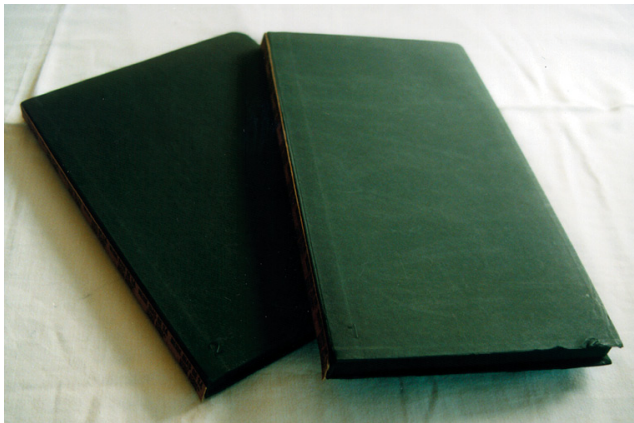

Neide Dias de Sá, capas-caixas de "livros poemas" de 1985.
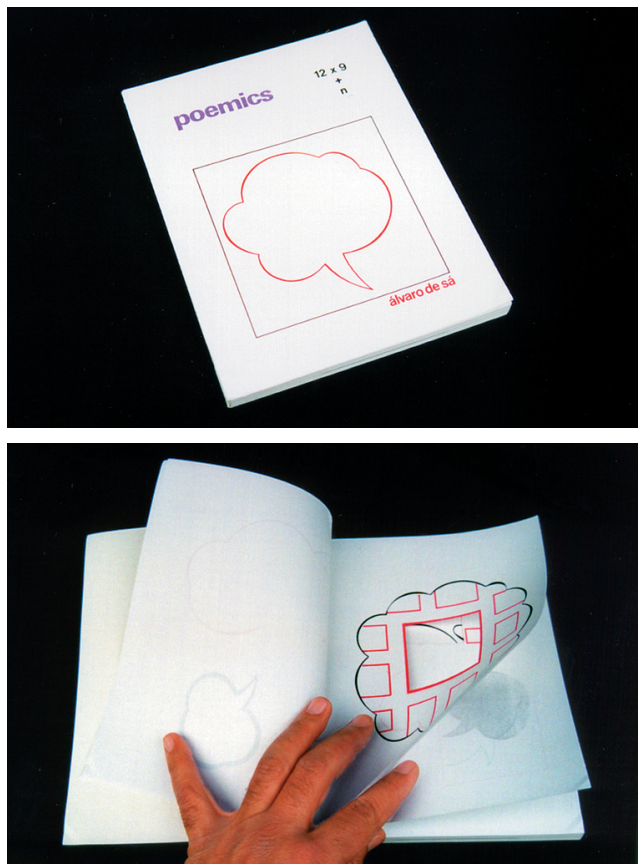

Alvaro de Sá, Poemics, 1991. bém permitiria a reprodução renovada da caligrafia manual por processos outros que a autografia litográfica. Se os primeiros caracteres impressos buscavam a subserviente reprodução do traço dos copistas, as modernas técnicas fotomecânicas, eletrostáticas e digitais passam a permitir ao artista a reprodução exata de sua escritura sem a necessidade de um grande esforço artesanal. Isso possibilita a exposição de um novo conjunto de vestígios do trabalho motor da mão. Dá-se uma outra maneira da escrita tangenciar a simples função verbal e se intrometer no corpo físico da página, unindo as mais arcaicas tradições ao comentário filosófico do gesto. Não apenas com seus percursos e voltas, fazendo o elogio da ação de escrever, mas propiciando o confronto 
da memória muscular da escritura com o questionamento lírico de seu valor.

A palavra escrita na obra de Enzo Miglietta é ao mesmo tempo o registro de uma operação metódica e o vestígio de um esvaziamento, de uma purgação. Palavra após palavra, linha após linha, Miglietta (que se assina "Em") traça caminhos escritos que se sucedem lado a lado ou entrecruzando-se, preenchendo espaços geométricos escrupulosamente construídos, ou criando paisagens e perspectivas, novos mundos paralelos habitados por seres e objetos caligráficos. $\mathrm{O}$ artista tem sua escritura presente na poesia visual e na arte postal da Itália, onde, desde 1971, mantém o Laboratorio di Poesia di Novoli (antes disso, entre 1945 e 1970, predominavam as experiências verbais). Seus manuscritos verbo-visuais se concentram principalmente no período de 1983 a 1994, geralmente superfícies planas grafadas com nanquim. São folhas, lâminas ou pranchas individuais (tavole pittografiche) ou que formam livros. Nelas a escritura é um material visual e corpóreo, considerado o resultado de uma obra em progresso. Nos seus trabalhos recentes, suas "palavras em liberdade" passam a ocupar a superfície de objetos descartados. Numa correspondência, Miglietta interrompe o seu italiano para nos assegurar, em inglês enfático, sobre seus últimos manuscritos sobre refugos: “Lixo??? Não!!!" Em sua obra, a própria palavra, como os objetos reais, tem sua permanência assegurada como valor artístico. Em texto avulso de 1999 ele esclarece.

Não é escrever, nem é fazer Arte, usar as letras do alfabeto e os objetos refugados para fazer um mínimo com eles; mas é
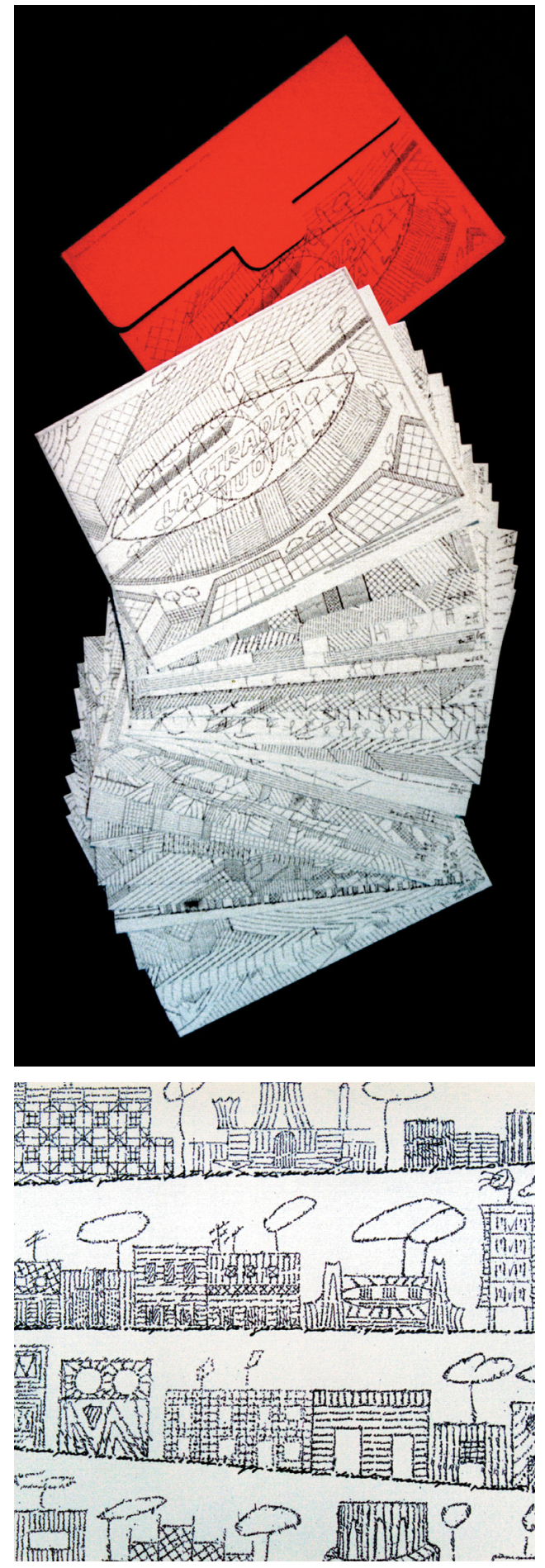

Enzo Miglietta, La strada nuova, 1994, com detalhe. Verso das folhas com texto manuscrito de 1969. 
fazê-los novamente funcionar sozinhos para si, dar-lhes mais uma vez um crédito. Mas interessar-se ainda por esses restos alfabéticos e de vida, realidade e virtualidade do mundo-homem... é possível? (p.5)

Em texto para o álbum de Miglietta, La strada nuova, 1994, Gino Pisanó fala dos trabalhos bidimensionais dos artista:

Miglietta opõe ao conceito a sua metástase: o signo. A poesia é puro registro de impressões sensoriais. A página, tabula rasa que veicula a consciência do poeta bombardeada por uma metralha de fenômenos que nenhuma metafísica reduz à unidade. O mundo é emaranhado.

As palavras podem ser lidas, sim, mas nem sempre. Existe um progressivo desaparecimento, um abandono de seu valor semântico em favor do valor emocional da própria motricidade. Tem-se uma redução da escrita como a entendemos usualmente. As milhares de vinhetas recobrem a superfície construindo e organizando uma planimetria apaixonada. Miglietta tem a consciência existencial da circunstância de ser um cidadão artista e poeta, e com ela traça a responsabilidade estética e moral agregada ao seu trabalho.

O livro é um corpo que contém alma. $\mathrm{E}$ a essa dualidade corresponde uma ação reveladora, a leitura. Se o livro pouco se modificou em sua história, a leitura, por outro lado, continua em exercício mais acelerado, prosseguindo pelo jogo da alternância ou simultaneidade $d a$ compreensão analítico-discursiva (entendimento por decodificação analítica) e da compreensão sintético-ideográfica (entendimento perceptivo). Ou seja, para o primeiro caso estamos na presença da página histórica: a página calada, muda,

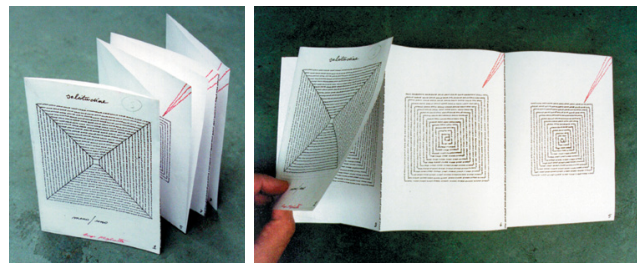

Enzo Miglietta, Solitudine, 1996.
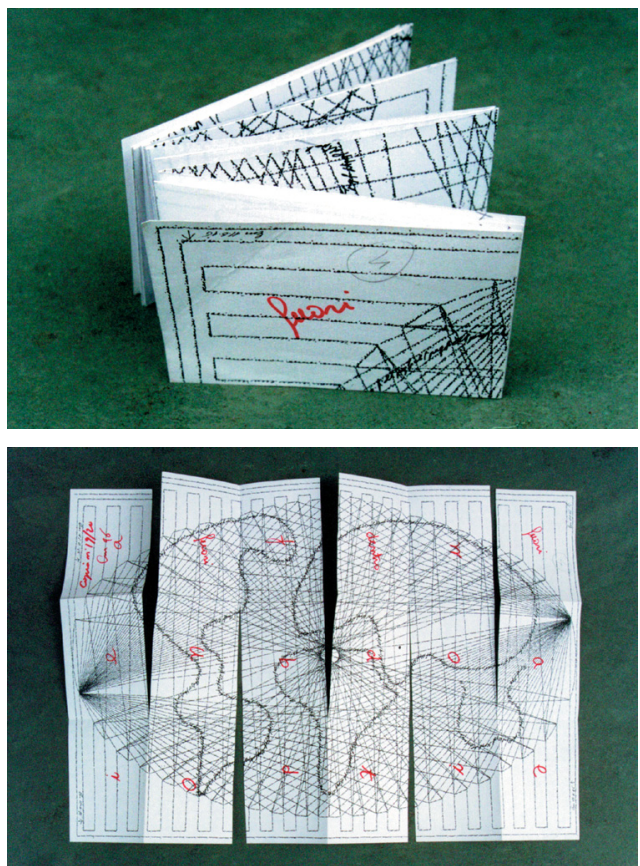

Enzo Miglietta, Fuori, 1996.

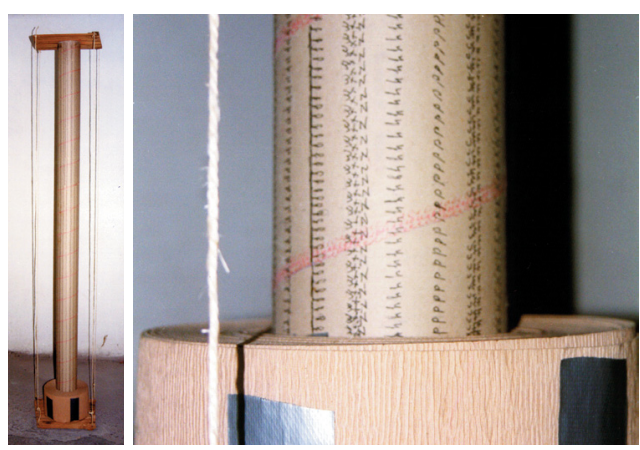

Enzo Miglietta, Testo colonna - La perdita della parola 11, 1999 (fotos cedidas pelo artista). 
que não passa de suporte para sinais gráficos convencionados. No segundo caso, a página tem a sua própria prolixidade, ela tem voz própria. Uma versão literária a esse entendimento foi dada por Ferreira Gullar ao definir o termo livro-poema.

Chamo de livro-poema (ou poema livro) à tentativa de usar a página (o livro) como um elemento interior ao poema. [...] $\mathrm{Na}$ verdade, segundo cremos, a palavra, com seu peso, obriga a página a vencer o limite tátil, submerge-a na dimensão temporal da linguagem. A página é pausa, duração, silêncio. Um silêncio verbal. Cortando-a, justapondo-a, procuro tornar audível o lado mudo da linguagem, o seu avesso. (Citado por Pontual, 1971, p.33-34)

Em 1991, Gullar conseguiu enfim publicar O formigueiro, seu livro-poema escrito em 1955 e que até então permanecia inédito. Algumas páginas foram apresentadas na Exposição Nacional de Arte Concreta, em 1956, em São Paulo, e em 1957, no Rio de Janeiro. Inicialmente com a palavra "a formiga", o livro prossegue pelo uso da sequencialidade desenvolvida pela desintegração do vocábulo, e pela relação entre letras, palavras e frases de um novo núcleo verbal com o espaço da página e o ato de folhear. A arte-final e a
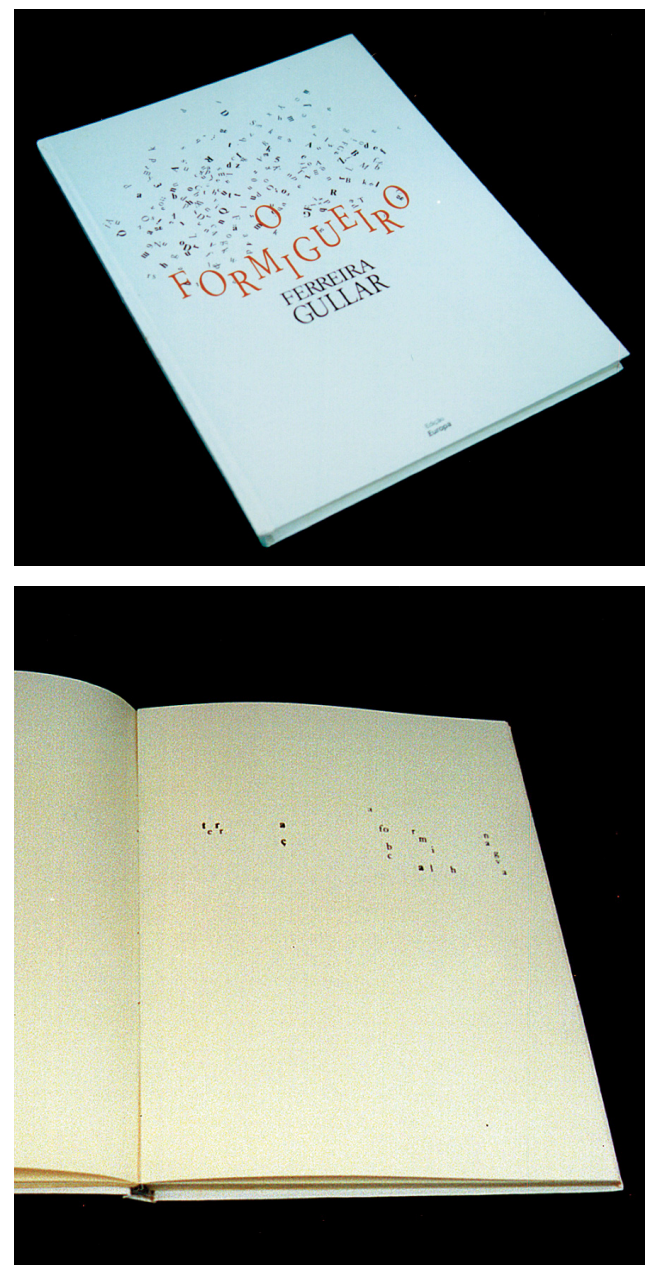

Ferreira Gullar, O formigueiro, 1991. capa também são dele, o que integra o trabalho. Gullar acredita que sua obra resgata a simplicidade do discurso poético, "em que pese a pretensão vanguardista daqueles anos e os maus resultados que esse tipo de poesia obteve". Ainda na apresentação do livro, Gullar afirma que teria “tentado uma transfiguração do objeto verbal”. Para ele, em O formigueiro “a ordem gráfica usual é violentada”.

Para Roberto Pontual, a busca de um novo livro é fruto da disposição para uma nova leitura. E entre os títulos que destaca está Flicts, de Ziraldo, para ele um livro-poema em que "cor e palavra se desdobravam unidas e mutuamente significantes" (p.37-38). Mas para Pontual, "salvo alguns exemplos de ruptura, mais ou menos drásticas, que a contemporaneidade vai se encarregando de diversificar, o livro permanece hoje fundamentalmente o mesmo". Sim e não. O que não permaneceria o mesmo seria o espectro do livro de artista, ampliado por experiências matéricas mais agressivas e 
posturas mais distantes da poesia, além de se constituir conceitualmente a partir dos anos 70, no interesse de constituir uma identidade isolada da do livro-objeto.

Nesses termos, Alvaro de Sá propôs as diferenças entre poesia-livro, poema-livro e livro-poema. O último teria uma idealização mais próxima do livro-objeto.

O que caracteriza o livro-poema é a fisicalidade do papel como parte integrante do poema, apresentando-se como um corpo físico, de tal maneira que o poema só existe porque existe o objeto (livro). A intenção do livro-poema não é a produção de um objeto acabado, mas, através de sua lógica interna, formar o poema durante o uso do livro, que funciona como um canal que, no seu manuseio, "limpa" a leitura fornecendo a informação, possibilitando assim um novo explorar em nível já de "escrita” sobre o livro "limpo": recuperação criativa dos dados informativos (versão). [...] O livro-poema não pode perder a característica de livro para ser filme ou cartaz. As propriedades físicas do material impedem esta transposição. (Sá, 1971, p.40 e 41)

Sá destaca a função fundadora de $A$ ave, de Wlademir Dias Pino.

\section{Mimese formal e funcional do corpo e da leitura}

Ficaria mais fácil para todos considerar o livro de artista no sentido estrito como um gênero literário, como um romance policial, uma peça teatral ou um livro infantil. Ou uma classificação por assunto, como um exemplar de autoajuda, um livro de receitas ou um atlas. Do segundo grupo ele de fato pode participar, desde que não ultrapasse os parâmetros mais ou menos consolidados: códice, caderno, bloco, carta e seus assemelhados. Será um produto e estará apto a receber um número internacional de referência (ISBN, International Standard Book Number). Os livros de artista recentes (às vezes mesmo os mais irreverentes) têm o seu número e código de barras impresso na contracapa ou em etiquetas adesivas. Isso agiliza a estocagem interna, a venda e a distribuição internacional. Afinal quem não quer vender?

O livro de artista não causa estranhamento apenas por parecer diferente. Ele também se expressa pelo parecer semelhante. É a mimese como ferramenta para o comentário irônico, para o humor, para o drama, para o rigor conceitual ou simplesmente para facilitar a portabilidade. Ela de fato já existia nos seus primórdios, mas interna a eles. Acontecia na relação de tradução entre texto e imagem no livro de pintor e no livro ilustrado. O primeiro, já vimos, era sofisticado e de baixa tiragem, dominado pela atmosfera requintada do artista, enquanto o segundo era um volume modesto, de maior circulação e dependente dos meios mecânicos de reprodução (Hubert, 1988, p.20). Em muitos momentos essas características se confundiram, como resultado dos perfis de consumo, da evolução tecnológica e do crescimento da inserção intelectual do artista no mercado de bens simbólicos. A mimese se transferirá da reprodução contida na página para a própria página em si. E, por decorrência, o volume. 
Nada mais natural que um livro pareça livro. Isso pode, entretanto, passar a ser o próprio assunto, bem como um propósito. Conservar o formato códice, não como estratégia de preservação, mas como estratégia de linguagem, agrega um valor cenográfico ao volume. Nesta metade do século, vivemos num momento em que as relações entre os veículos (ou entre as formas de expressão) são mútuas, ou simultâneas, ou alternadas, mas sempre relativas umas às outras. Mas de um modo geometricamente mais intenso do que na primeira metade. A essa integração de meios foi dado o nome "intermídia", denominação cunhada nos anos 60 pelo inglês Dick Higgins (1938-1998), artista experimental co-fundador do grupo Fluxus e criador de Something Else Press, uma das mais importantes casas publicadoras de obras alternativas. Para alguns, a influência da presença de Higgins na arte deste século deve ser estudada contextualizadamente e em paralelo com Marcel Duchamp e John Cage. ${ }^{32} \mathrm{O}$ conceito de intermídia está desenvolvido em seu livro FoewËombwhnw: a grammar of the mind and a phenomenology of love and a science of the arts as seem by a stalker of the wild mushroom, 1969, mais ou menos "uma gramática da mente e uma fenomenologia do amor e uma ciência das artes como vista por um acossador do cogumelo selvagem" (note a dificuldade em traduzir stalker adequadamente). Além de reproduzir o artigo publicado antes em 1966, ele é formado pela reunião de escri-
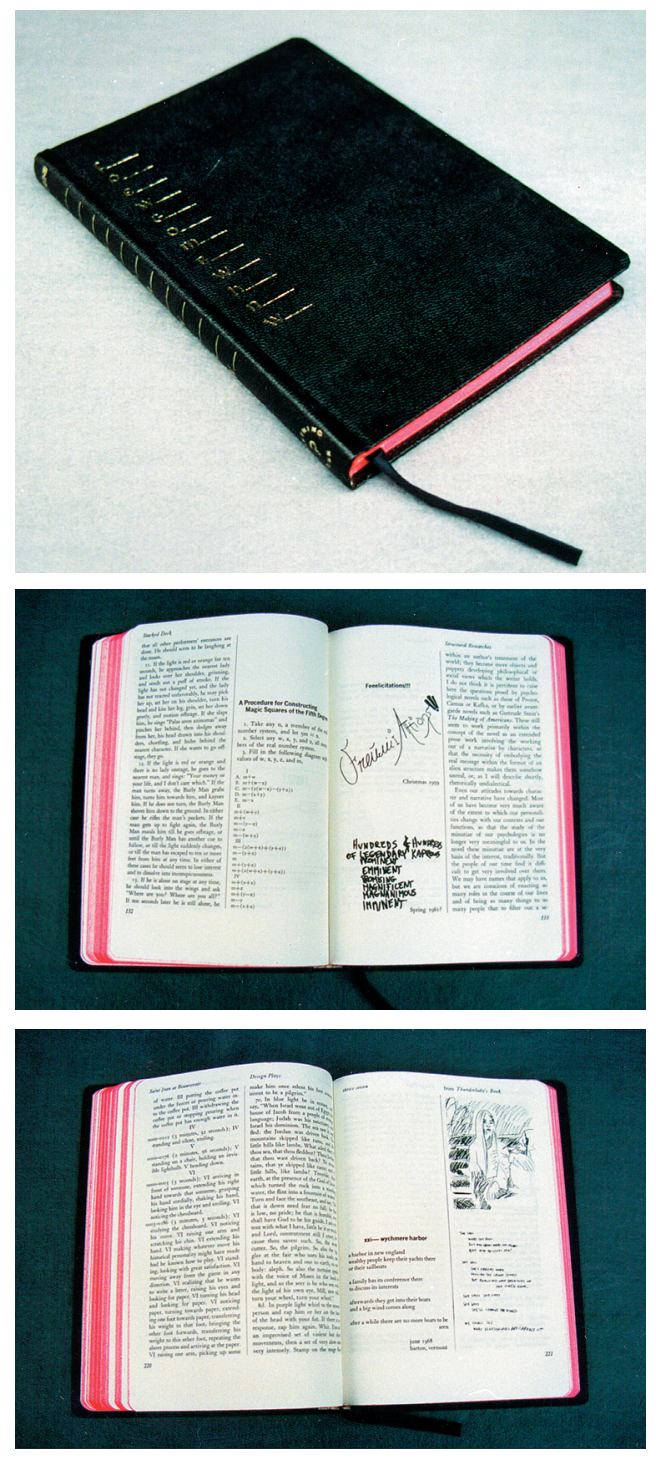

Dick Higgins, Foew Eัombwhnw: a grammar of the mind and a phenomenology of love and a science of the arts as seem by a stalker of the wild mushroom, 1969. tos, comentários, poemas visuais, propostas para encenações, roteiros para performances, desenhos, caligrafias e algumas reproduções de fotos ou documentos (há inclusive uma tradução de poema de Pedro Xisto). O material escrito é diagramado em duas colunas

${ }^{32}$ A esse respeito, ver a edição de Umbrella de dezembro de 1998, em homenagem a Higgins. 
paralelas independentes, separadas por um fio. Um texto que inicie na coluna da esquerda de uma página par, continuará na coluna da esquerda da página par seguinte. Desse modo, o livro aberto apresenta quatro dinâmicas (ou movimentos) de leitura diferentes, lado a lado, no decorrer de suas 320 páginas. Isso pode sugerir que ele seja lido quatro vezes. É impresso em papel de baixa espessura, com as bordas tingidas de vermelho rosado. A capa dura é revestida de falso couro negro. As folhas de guarda também são negras, assim como é negra a fita marcadora de páginas. Os textos e os símbolos da capa são dourados. O livro se apresenta, assim, como uma pequena bíblia, dessas comuns nas gavetas dos quartos de hotéis norte-americanos. É arriscado afirmar que isso tenha a dimensão do sacrilégio, sem que se tenha sido testemunha do momento e da maneira de sua inserção no mercado. Mas é razoável acreditarmos na ironia de paródia presente na sua concepção cosmopolita, dentro de um contexto que incluía de jovens indo para o Vietnã até o movimento hippie. Note-se o símbolo do Yin e Yang na contracapa, onde poderia estar um símbolo cristão. Quanto ao título, parece ser composto pelas iniciais do primeiro título que ele deveria ter, Freaked out electronic wizards $\mathcal{E}$ other marvelous bartenders who have no wings, um título que teria vindo a ele. Talvez possa ser traduzido por "Mágicos eletrônicos ligados \& outros barmen maravilhosos que não têm asas". Segundo o seu prefácio, espera-se que a obra "ajude a converter a cena cultural da histeria e frigidez dos anos 50 e 60 para o que poderão ser os serenos anos 70 "(!).

Entre outros títulos antes desse, Something Else havia editado outro livro que não era exatamente o que parecia. Foi a edição em língua inglesa de Topographie anecdotée du hasard, de Daniel Spoerri, um pequeno catálogo publicado em 1962 por Editions Galerie Lawrence, Paris (esta edição original era em francês e inteiramente sem imagens). An anecdoted topography of chance ("versão reanedotizada"), 1966, teve a colaboração de Robert Filliou, tradução de Emmett Williams e cem ilustrações "reflexivas" de Roland Topor. Uma anedota não diz respeito apenas a um relato engraçado, mas também a um fato curioso ligado à experiência real. O livro tem uma impressão tipográfica muito antiquada, parecendo as velhas seletas de textos escolares, ou livros de receitas anteriores ao uso da cor, ou ainda a glossários populares que reuniam algum conhecimento mundano como ciência. Ele tem um formato banal, industrial, pequeno

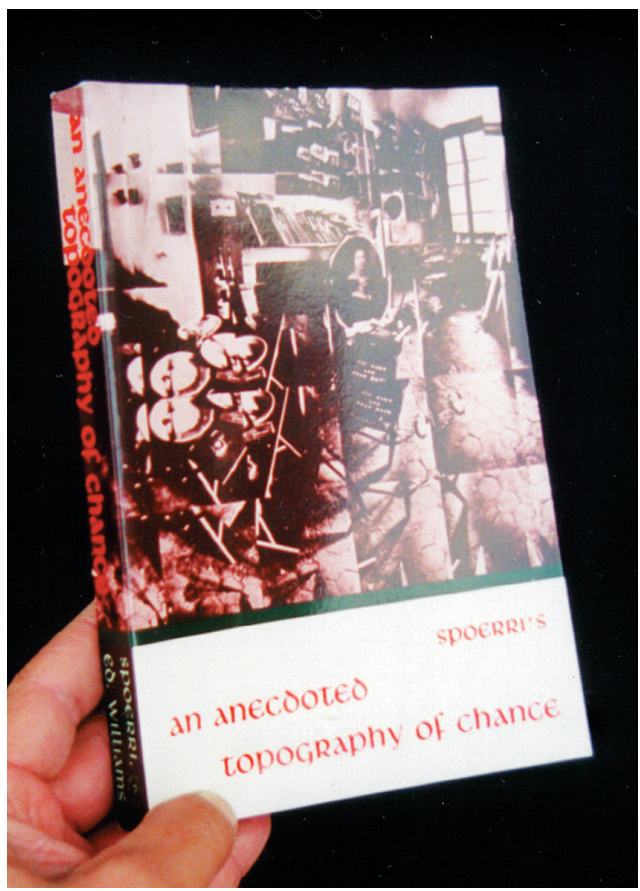

Daniel Spoerri, An anecdoted topography of chance, 1966. 
$(20,4 \times 13,7 \mathrm{~cm}),{ }^{33}$ com 240 páginas. ${ }^{34}$ An anecdoted.. é um bom exemplo da passagem para livro do projeto criativo de Spoerri, a anatomia do momento pela fixação de objetos cotidianos em desordem (ou ordem orgânica) sobre uma superfície, como a mumificação em reverso de um sítio arqueológico urbano. A fixação comentada é de 17 de outubro de 1961, às 15 horas e 47 minutos. Na introdução (p.XV), ele apresenta a proposta.

No meu quarto, número 13 do quinto andar do Hotel Carcassonne, na Rua Mouffetard, 24, à direita da porta de entrada, entre o fogão e a pia, está uma mesa que Vera um dia pintou de azul para me surpreender. Eu me coloquei a caminho aqui para ver o que os objetos numa seção dessa mesa [...] poderiam me sugerir, o que eles poderiam espontaneamente despertar em mim ao descrevê-los: o modo em que Sherlock Holmes, iniciando de um único objeto, poderia resolver um crime; ou em que historiadores, após séculos, foram capazes de reconstituir toda uma época da mais famosa fixação da história, Pompeia.

Suas fixações de sobras humanas foram inspiradas nas latas de lixo de Arman, vistas pela primeira vez dois anos antes (segundo nota da página 106). No início do livro há um desenho em diagrama mostrando os 101 objetos aos quais correspondem os 101 artigos adiante. Cada artigo tem normalmente uma pequena coluna de texto, muitas vezes com apenas uma frase. Ao lado, há uma pequena ilustração em bico-de-pena do objeto.

[34 (continuação)]

\section{(d) Invólucro plástico branco}

para uma bateria de gravador. Eu comprei o gravador enquanto eu estava em Amsterdã (veja no 25, nota ***) durante a exibição "Arte em Movimento"; as baterias foram esgotadas e substituídas logo depois em Estocolmo, onde Pontus Hulten, diretor do Moderna Museet, montou a mesma exposição. Eu cochilei com o gravador funcionando, e acabei com as baterias durante a noite.** (p.75)

Seguem-se as notas adicionais, muitas, do autor, e as notas do tradutor, também muitas, além de informações diversas, reproduções de diálogos gravados, remissões, etc., traçando um histórico do objeto.

\footnotetext{
${ }^{33} \mathrm{O}$ uso da guilhotina em uma gráfica mais antiquada depende muito da atenção de um operador que, por ser humano, pode errar por descuido durante o procedimento ou por causa do próprio desgaste do equipamento e do tipo de livro que está sendo refilado. Mundialmente predominam os formatos $21 \mathrm{x} 14$ e 23x16, com pequenas alterações para mais ou para menos (atenção: gráficos costumam designar as dimensões em ordem inversa, primeiro a largura e depois a altura). Por esse motivo, alguns formatos citados poderão diferir do registrado na bibliografia consultada. Em Moeglin-Delcroix, 1997, p.130, por exemplo, o livro de Spoerri tem 20 x 13,5cm. E no catálogo de 1986 de Printed Matter, tem 20 x 14 cm.

${ }^{34} \mathrm{O}$ livro possui uma parte pré-textual, paginada com números romanos até XVIII, além de duas páginas impressas não numeradas antes do corpo principal do miolo. Além disso, ele possui seis páginas em branco no final. A última página impressa é a de número 214. Uma referência bibliográfica ligeira, mas não incorreta, informaria que ele tem 214 páginas, o que não é verdadeiro. Pouco importa para esta pesquisa se a obra tem páginas em branco, sem texto, que não participem de seu substrato de leitura. O livro é considerado como corpo físico no todo. O que existe, existe. É um livro com sete cadernos de 32 páginas e um meio-caderno com 16, totalizando 240, em capa dura ou brochura.
} 
Nota Adicional do Autor

*** A propósito de museus e exposições: passando um dia com Robert Filliou na Rue des Rosiers, onde ele viveu depois de sua expulsão da Dinamarca, e que é a rua principal do bairro judeu em $\mathrm{Pa}-$ ris, nós vimos numa loja cerca de vinte galinhas numa parede de gaiolas. (Nesse quarteirão as aves domésticas são mantidas vivas até serem mortas de acordo com o ritual kosher.) À medida que nos aventurávamos no interior, sem querer provocamos uma disputa entre um velho que estava sentado numa cadeira e uma mal-humorada velhinha, que depenava uma galinha. Ele queria que entrássemos, mas ela nos avisou que sua loja não era um museu. Ele assegurou a ela que nós não iríamos comer suas galinhas, mas ela repetia sem parar: "Não tem nenhum museu aqui, isso não é um museu”. Enfim levados para fora, mas chateados, Filliou ressaltou que o incidente valia uma notação na Topografia, porque certamente foi na loja "Nadia's Frangos Vivos, Estritamente Kosher" que o ovo de Brancusi no Moderna Museet de Estocolmo foi chocado. Nota do tradutor 3 .

Nota do Tradutor 3

Mais sobre o assunto de Museus: Allan Kaprow escreveu em sua introdução a [...]

E a nota prossegue ainda mais extensa do que a anterior. Tudo em função de um simples invólucro plástico. A sua leitura pressupõe um jogo de ir e vir até o diagrama inicial, reproduzindo a mesa em uma maquete mental, ao mesmo tempo em que, de nota em nota, estabelece-se um rigor estritamente narrativo-descritivo. $\mathrm{O}$ todo dessas relações, juntamente com a sua proposta, fazem do livro de Spoerri uma obra contemporânea de artes visuais, apesar da ferramenta literária (e até por causa dela). Como no citado livro de Higgins, aqui também podem ser localizadas muitas informações sobre aquele momento artístico.
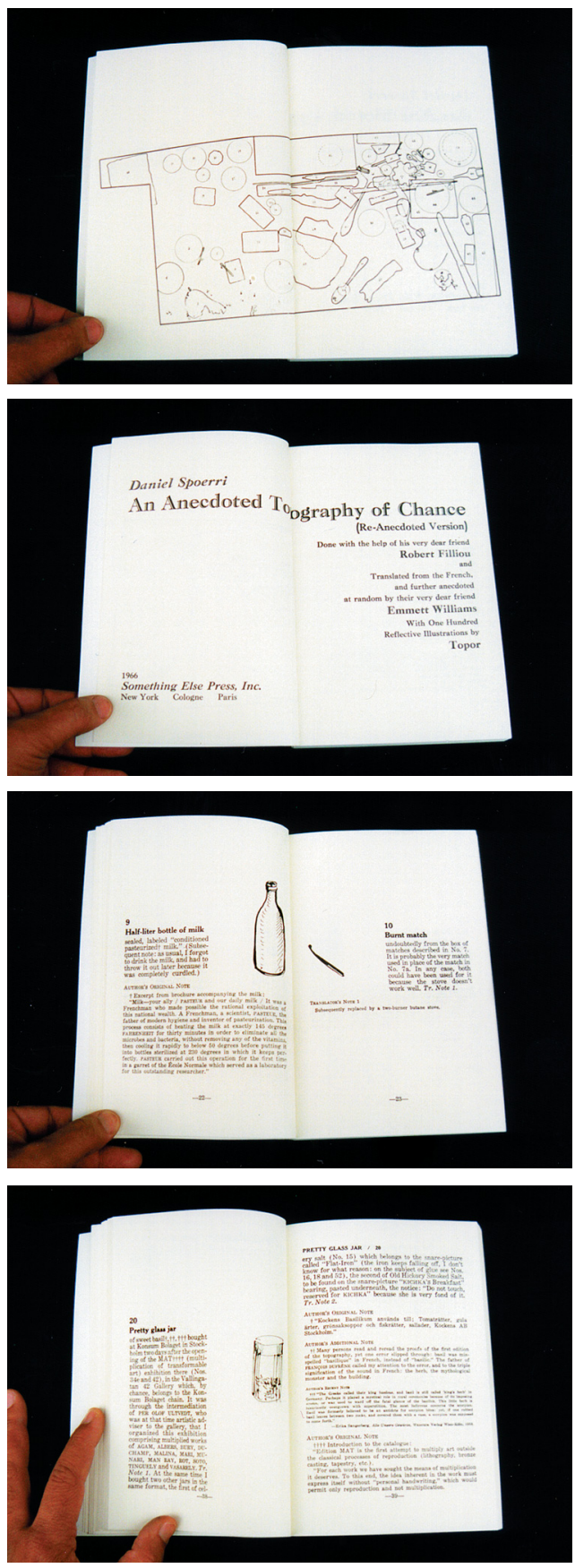

Daniel Spoerri, An anecdoted topography of chance, 1966. 
Estabelece-se a primeira função de um livro: guardar conhecimento, ou uma verdade. $\mathrm{E}$ isso acontecendo em objetos artísticos de vanguarda, paradoxalmente em formas de apresentação travestidas.

O mimetismo extremado com a forma códice e com os gêneros bibliográficos que dependem dela é, de fato, mais versátil do que aparenta. Entretanto, a presença conceitual da arte dentro dos limites dessa forma implica duas situações diferenciadas. Primeiro, tão rápido quanto o artista entrou na categoria do livro de artista, ele pode atravessá-la totalmente e cair em gêneros simplesmente literários, ensaísticos ou ficcionais. E segundo, a tolerância excessiva ou a defesa insistente da arte conceitual podem permitir a entrada em exposições de arte (e, portanto, legitimação) de livros que não são obras de arte. A exposição Artist/Author: Contemporary Artists' Books parece ter sido uma das maiores dentre as mais recentes. Itinerante pelos Estados Unidos, ela cumpriu calendário de fevereiro de 1998 até dezembro de 1999, em seis Estados. O livro (e catálogo) publicado para acompanhá-la é indispensável para a compreensão do momento internacional do livro de artista estrito. A coordenação dos trabalhos (eventos, livro, etc.) foi de Cornelia Lauf, historiadora de arte e editora na Bélgica, e de Clive Phillpot, que, em tese, estaria aposentado. Brad Freeman, em reportagem para $J A B$ 11 (1999, p.25), destaca como um dos muitos méritos da exposição a disponibilidade da maioria dos volumes para exame pelo público. Para isso, cada participante enviou dez exemplares das obras. Entretanto, ele nota a existência de alguns desequilíbrios, como o próprio catálogo demonstra, definindo como sendo "uma corrida de montanha-russa do maravilhoso ao medonho". Destaca as contribuições de Phillpot, mas expõe um certo grau de discordância com ele quanto ao início de uma história dos livros de artista e a quase impertinente insistência no livro de baixo preço. Critica duramente algumas opiniões de Cornelia Lauf, especialmente sua apropriação de conceitos para qualificar o próprio catálogo da mostra como um livro de artista. E, por fim (p.29), afirma que são "tantos os livros em exibição que não são realmente livros de artista, que eu duvido da legitimidade e sinceridade da política curatorial". Examinando-se mesmo que rapidamente o acervo exposto, a primeira sensação é de que existem muitos episódios de aproximação entre a arte, o projeto gráfico e a editoração, às vezes inclusive com apropriação de recursos da publicidade, não de forma crítica, mas de apresentação gráfica. Mas se por um lado não se pode negar que isso determina uma tendência, por outro penso que nem todo o material exposto é livro de artista. Falo de um caso específico, Remote control.

Remote control:power, cultures, and the world of appearances, 1993, de Barbara Kruger, é um livro convencional,
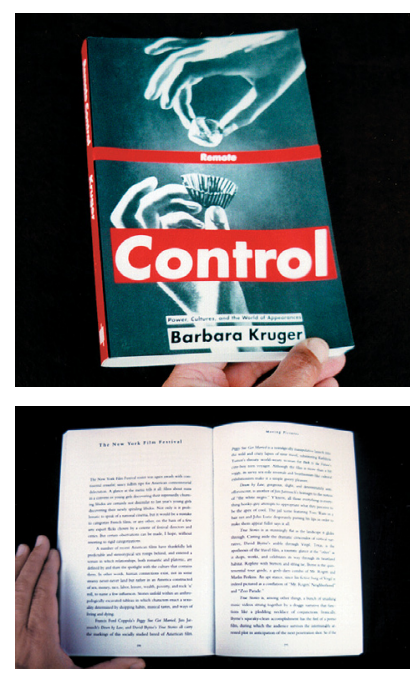

Barbara Kruger, Remote control: power, cultures, and the world of appearances, 1993. 
com uma edição em brochura em 1994, com 256 páginas. A capa é em duas impressões de preto e vermelho, elaborada por Kruger dentro de seu estilo característico. O corpo do texto é formado por uma antologia de 64 pequenos artigos e resenhas sobre televisão e cinema, principalmente, de Miami Vice a Memórias do Cárcere. Alguns textos são inéditos, mas a maioria foi publicada em jornais e revistas, grande parte na coluna Remote Control da revista Artforum. É tudo texto, não existem imagens ou qualquer diferenciador visual. A inclusão desta e de outras obras parecidas é justificada por Lauf pela evolução do campo no sentido do projeto gráfico, como sinal de maturidade de ambos. A própria formação profissional de Kruger é utilizada para demonstrar essa posição: "Tenho de dizer que a maior influência no meu trabalho, em nível visual e formal, foi a minha experiência como projetista gráfica - os anos despendidos executando exercícios em série com figuras e palavras. Assim, num tipo de moda circular, meu 'labor' como projetista se tornou, com poucos ajustamentos, meu 'trabalho' como uma artista”. (Lauf e Phillpot, 1998, p.78; Lauf, citando Barbara Kruger, citada por Stiles e Selz, 1966, p.377) Para mim, ele não é um livro de artista em sentido nenhum. Ele é um livro comum, banal, de ensaios, a maioria do campo da comunicação social. Os ensaios, aliás, são muito interessantes, porque Kruger é muito interessante. Vale como sugestão a "máxima" número 16 de Sol LeWitt: "Se são utilizadas palavras, e elas procedem de ideias sobre arte, então elas serão arte e não literatura, números e não matemática" ${ }^{35}$ Ele não está falando de literatura sobre arte, mas sobre uso de palavras que se torna arte. Isso significa que, no nosso caso, um escrito de artista não conduz necessariamente a um livro de artista. Ele é a verbalização cursiva ou tipográfica do pensamento, que pode ou não constituir uma coisa artística, um objeto artístico. Um escrito de artista é da dimensão do discurso direto. É um artist's writing, um écrit d'artiste, etc. Como os escritos de viajantes eles não geram, necessariamente, obras diferenciadas, embora o possam. Em Remote control não se percebe a existência de uma proposta artística voltada ao livro ou de um projeto conceitual, ou gráfico, ou gráfico e conceitual. O que existe é um projeto editorial. A plasticidade fica dentro de padrões internacionais de editoração, à exceção da capa que, afinal, é de Kruger. Mas quanto ao livro mesmo, ele não tem função de obra de arte. Não se sente que um artista o tenha concebido. Onde está a intenção? Ele não provoca estranhamento ou encantamento. Ele não vibra nas minhas mãos e nem olha para mim. Ele não é arte. E nem antiarte.

De fato as instituições da arte estão em constante ajuste às ocorrências do meio. E é plausível que procurem entender e catalogar os seus fenômenos. A inserção de Remote Control numa exposição de porte acima do usual caracteriza a maleabilidade do processo, que pode trazer inconformidade. Mas se por um lado isso distende artificialmente o universo de obras que podem ser classificadas como livros de artista, por outro pode oferecer, também, novas avaliações. Como alguns livros de Bruno Munari (1907-1998), destinados ao mercado comercial, que marcaram época junto aos estu-

\footnotetext{
${ }^{35}$ Art-Language: the journal of conceptual art, v.1, n.1, may 1969, p.12.
} 
dantes de arte e comunicação. Esse é o caso de, entre outros, Arte come mestiere ( $A$ arte como oficio), 1966, Design e comunicazione visiva (Design e comunicação visual), 1968, Artista e designer, 1971, e Fantasia, 1977. Todos os quatro têm uma identidade criativa muito pessoal, rara nos produtos de comunicação, e uma comunicabilidade explícita, por sua vez pouco frequente na arte contemporânea. Arte informativa? Quem sabe. Em todo caso, o projeto italiano Catalogar Arte os incluiu em sua publicação Libri d'artista in Italia 1960-1998, coordenada por Liliana Dematteis e Giorgio Maffei, na qual estão listados cerca de três mil livros de setecentos artistas. As obras comerciais de Munari têm inúmeras qualidades que proporcionam a sua inclusão nessa multiterritorialidade. Mas ainda assim sua apresentação (texto e contexto) ainda está mais próxima do livro comum. Talvez exemplos mais adequados dessa passagem de territórios sejam os livros Disegnare un albero (Desenhar uma árvore), 1978, e Disegnare il sole (Desenhar o sol), 1979, que também estão registrados no catálogo de Dematteis e Maffei. São obras mais leves e singelas, mas boas representantes do controle artístico da página e do volume. Além disso, possuem um certo sabor de independência, o que lhes dá uma identidade muito própria. Esses títulos são facilmente encontráveis nas livrarias do Brasil, por terem sido publicados em Portugal para distribuição comercial nos mercados de língua portuguesa.

Não estou defendendo a necessidade de haver a presença de "figura e fundo"(normas estanques). Acho imprescindível uma proposta, um projeto e uma concepção, fundamentados no pensamento artístico. Os livros de Higgins e Spoerri devem ter causado surpresa ao público erudito por serem mimetizados à literatura popular. Eles apresentam um explícito simulacro formal, com soluções estabelecidas para determinados gêneros comerciais, o que implica uma função ativa da visualidade. Mas essa ação visual não deve ser tomada como regra. Afinal, esses livros não se completariam sem a leitura lúdica. Mas mesmo a leitura tradicional sozinha pode fazer de um livro um livro de artista, se houver uma proposta que respalde isso.

Jenny Holzer, que tem sua vida artística construída na relação conceitual entre semântica locucional e a inserção do indivíduo em sociedade, usa de frases e pequenos textos para agir artisticamente, principalmente com o sucesso de seus "truísmos" de fins dos anos 70. Nada mais natural que um livro seu seja elaborado apenas com palavras. Esse foi o caso de Truims and essays, 1983, com epigramas e ensaios escritos entre 1979 e 1982, e que prosseguiu no livreto para acompanhá-la na 44ª Bienal de Veneza, The Venice installation, 1990. Com projeto de Holzer mais dois colaboradores, ${ }^{36}$ The Venice... é um livreto que tem como única sugestão de imagem o xadrez vermelho e preto das falsas folhas de guarda, remetendo ao chão com pedras. Faz uma antologia de 1977 até 1989, além de um pequeno "texto de Veneza", de 1990, pertencente a um momento intensamente mais pessoal, limítrofe do objetivo, com mais forte peso lírico (p.23).

${ }^{36}$ Projeto de Jenny Holzer, mais Bill Wisniewski e Lynne Holfelner, para Albright-Knox Art Gallery. 
Texto de Veneza

1990

Eu sou indiferente a mim mesma mas não para minha criança.

Eu sempre justifiquei minha inatividade e negligência em

face do perigo porque eu tinha certeza de ser vítima de alguém.

Eu sorri e me demorei em culposa expectativa. Agora eu devo ficar aqui a observá-la.

$\mathrm{Eu}$ experimento para ver se posso suportar a dor dela.

Eu não posso.

Eu sou dissimulada e desonesta falando sobre por que eu deveria ser mantida viva mas não é desse jeito com ela. Ela precisa estar boa porque sua mente não oferecerá nenhum esconderijo se a doença ou a violência a encontrar. Eu quero ser mais do que sua tutora e uma amiga do carrasco.

Foda-se eu mesma e fodam-se todos vocês que desejariam feri-la. ${ }^{37}$

The Venice... fez parte de um conjunto de intervenções que incluíam de camisetas a transmissões de televisão, além da instalação original. Mantém uma certa personalidade de catálogo, inclusive com um ensaio complementar do curador, Michael Auping. Para a função de livreto-catálogo, teve a tiragem de 4 mil cópias. Após a Bienal de Veneza, ainda teve (ao menos até 1992) mais 6.500 cópias em três reimpressões. $\mathrm{Na}$ verdade, esse trabalho tem uma certa
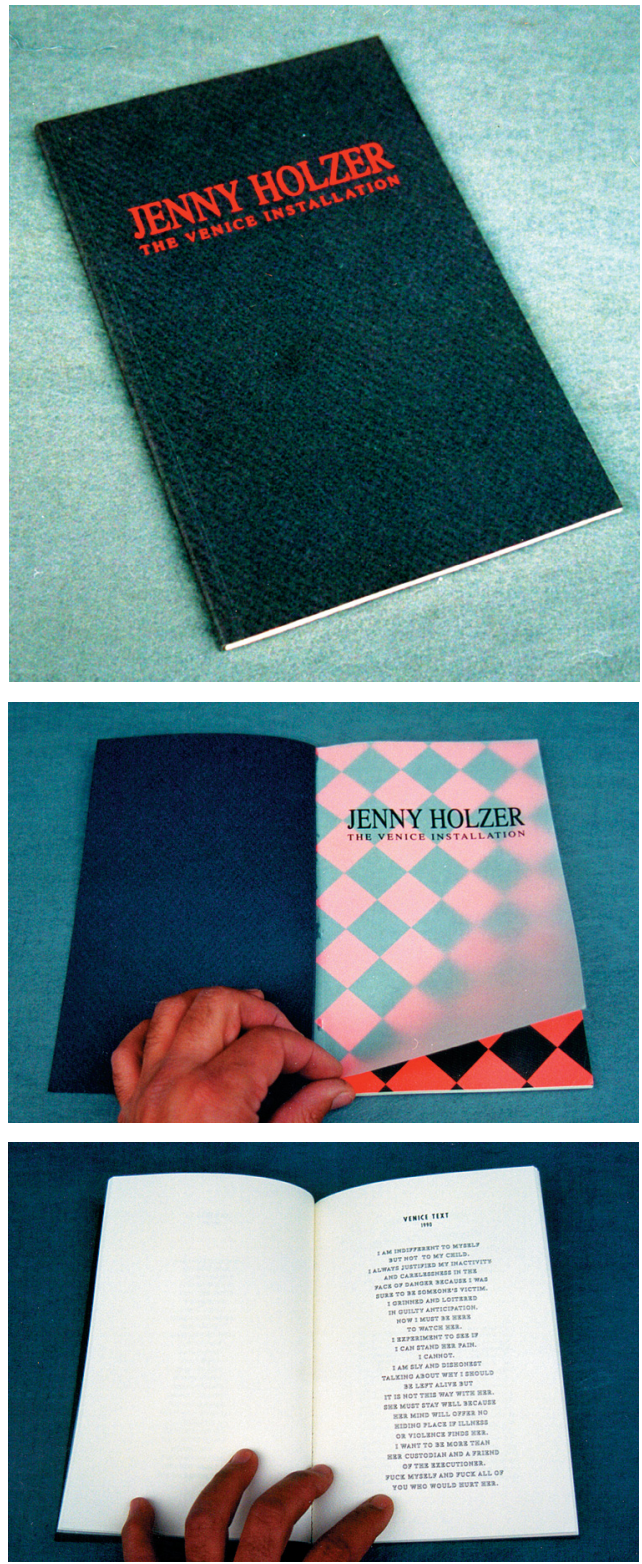

Jenny Holzer, The Venice installation, 1990.

\footnotetext{
${ }^{37} \mathrm{~A}$ tradução foi feita literalmente e depois revisada por Alice Monsell, que sugeriu a manutenção de certas asperezas do original, mesmo que soem um pouco estranhas. A revisão do português foi feita por Geraldo Huff, que observou o problema da utilização constante de pronomes na língua inglesa, o que não é usual em português. Considerando a intimidade expressada, o grande número de pronomes foi mais ou menos mantido. A quebra das linhas procura ser semelhante ao original.
} 
visibilidade, muito sutil, mas não poderia ser de outra forma, já que Holzer também se impõe parâmetros. Seus truísmos, por exemplo, devem ser sempre impressos em caracteres negritos itálicos. E o texto acima, em caracteres vazados ou gravado na pedra.

Como informação complementar, deve ser dito que o texto de Holzer em português está quebrado mais ou menos como no original inglês. Ela não faz poesia: "De forma alguma. Pode ser arte, às vezes... Mas poesia nunca”. A essa consideração, dada em entrevista para uma revista, ${ }^{38}$ ela acrescentou esclarecimentos sobre por que teria passado a usar frases intimistas em espaços públicos.

Acho que [...] é uma insistência de que a vida pessoal não seja esquecida, não seja posta de lado. Para muita gente, o que realmente interessa é o que acontece em suas vidas particulares, e faço obras sobre tragédias pessoais já há algum tempo. Elas são chamamentos para que se pense a respeito, no meio de uma caminhada, no intervalo do trabalho cotidiano; não são feitas para uma interpretação.

Mais cru e realmente sem nenhum adereço, foi o livreto de Douglas Huebler, Secrets, 1973. O projeto de Huebler (falecido em 1997) teve início com a exposição Software, em 1969, onde o visitante era solicitado a escrever num papel, sem identificação, um segredo pessoal que nunca tivesse sido revelado. Esse papel era colocado em uma urna e o visitante, em troca, recebia uma fotocópia de um segredo colocado na urna no dia anterior. $O$ processo se concluiu com a impressão dos cerca de 1.800 segredos em um livro de artista. Nele, um após outro, os segredos podem ser tão hilariantes quanto comovedores.

Minha mãe tem 38.

[...]

Meu obstetra é sexy.

[...]

Eu era parcialmente homossexual antes da terapia. Agora...

[...]

Eu tenho um seio menor que o outro.

[...]

Eu desejei que minha avó morresse quando ela esteve doente.

[...]
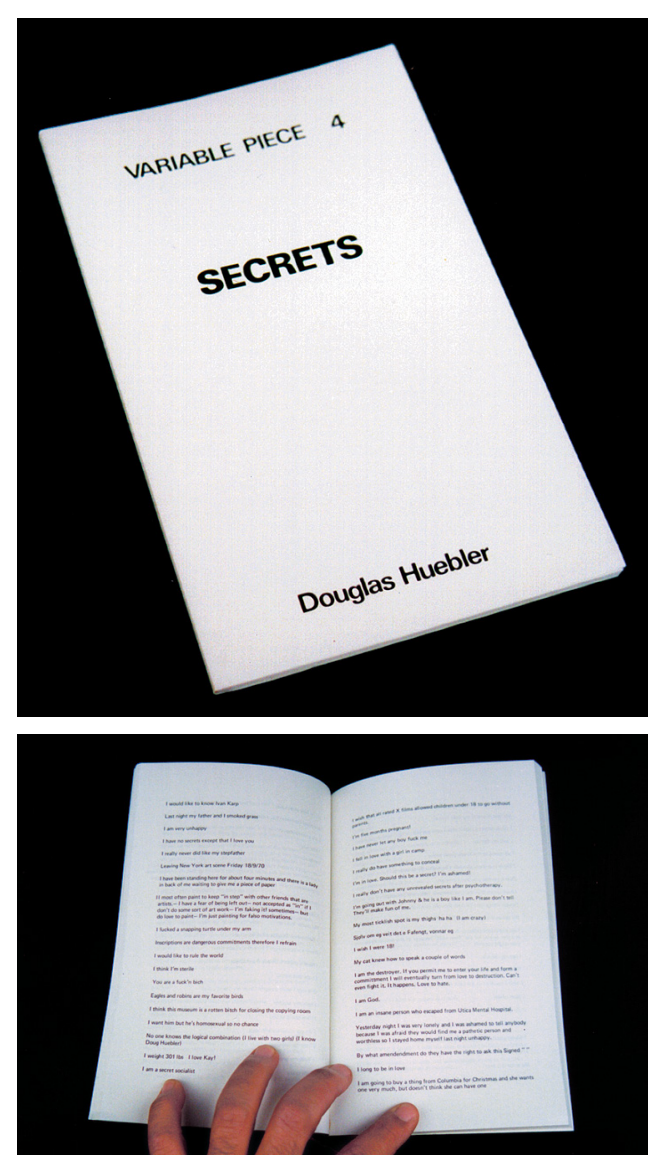

${ }^{38}$ Entrevista para André Luiz Barros em Bravo!, n. 20, maio 99, p.43.

Douglas Huebler, Variable piece 4: Secrets, 1977. 
Eu matei um gato aos quatro anos.

$[\ldots]$

Secretamente, eu acho que Douglas

Huebler está desperdiçando seu tempo.

[...]

Eu não amo meu marido.

$[\ldots]$

Caroline Kennedy é da minha escola.

[...]

Eu sou Spiro Agnew.

$[\ldots]$

Tenho câncer.

Os segredos podem não ser tão segredos assim, podem ser apenas brincadeiras ("Enganei você - eu não tenho segredo e você revelou o seu.”), possíveis fantasias ("Eu gostaria de ver meu antigo namorado apesar de estar casada e feliz há 10 anos.”), ou desabafos ("Eu amo minha ex-esposa mais do que minha atual esposa."). Um grande número envolve problemas do afeto amoroso ou revelações de preferências sexuais. Alguns questionam a proposta, por escárnio ou não. Como são frases simples, eles permitem uma diagramação seca, simplesmente arrolados em páginas brancas sem fólios. A capa é também branca, sem decoração alguma, apenas palavras (título, autor, etc.). Não há motivo ou necessidade da forma do livreto ser diferente da que ele tem. Neste caso, o que a pobreza do aspecto esconde é que é o evento artístico da página.

Muitos, mas muitos mesmo, livros com o códice como arquétipo são, e continuam sendo, elaborados para transmitir dissertações, descrições ou narrações que pertencem, pela forma ou pelo conteúdo, ao universo das artes visuais. Tanto a norma sintática como a morfológica são violadas pelo exercício perceptivo, mesmo que o códice permaneça inalterado (ou alterado sutilmente) como forma, ou que a informação permaneça inalterada (ou alterada
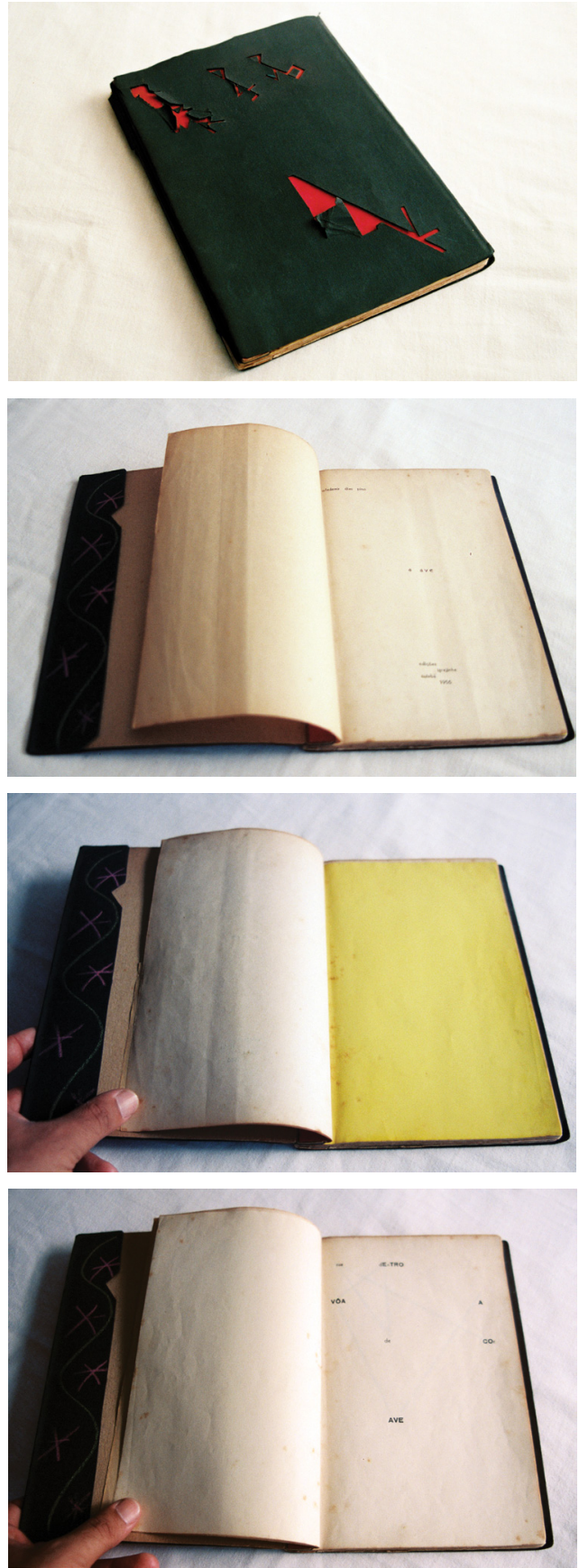

Wlademir Dias Pino, A ave, 1956. 
sutilmente) como função. Como acontece com os livros de Wlademir Dias Pino.

A manifestação de apego ao livro tem sido uma constante na vida de Dias Pino. ${ }^{39}$ Um apego que está evidenciado na forma códice de $A$ ave ou na função informativa da Enciclopédia visual. As obras de Pino estão situadas numa zona de interseção múltipla. Seu período histórico é o que envolve os principais movimentos políticos do Brasil, com os quais interagiu com ideias e ações. Seu mundo geográfico é cosmopolita, indo das diversões urbanas do eixo Rio-São Paulo até o testemunho em Cuiabá das migrações para o oeste. Sua vida cultural é um ponto equidistante entre as artes gráficas, as artes plásticas e a poesia, tendo tido atividades tão diferentes quanto ter criado o primeiro carnaval de rua abstrato do Rio de Janeiro, ou transformar poemas em gráficos estatísticos. Profundamente ligado à poesia concreta, primeiro, e depois com o poema-processo, seu envolvimento parece ser ainda mais profundo com a visualidade e o critério que envolvem o propósito e o gesto de publicar.

$A$ ave é possivelmente o primeiro livro de artista brasileiro pleno, que se autocomenta, concebido e executado integralmente por um único artista, dependente da sequencialidade das páginas e inadaptável para outros meios. Sua idealização remontaria a 1948, segundo o artista, sendo executado a partir de 1954. Foi impresso em fins de 1955 para lançamento em abril de 1956. Teve tiragem
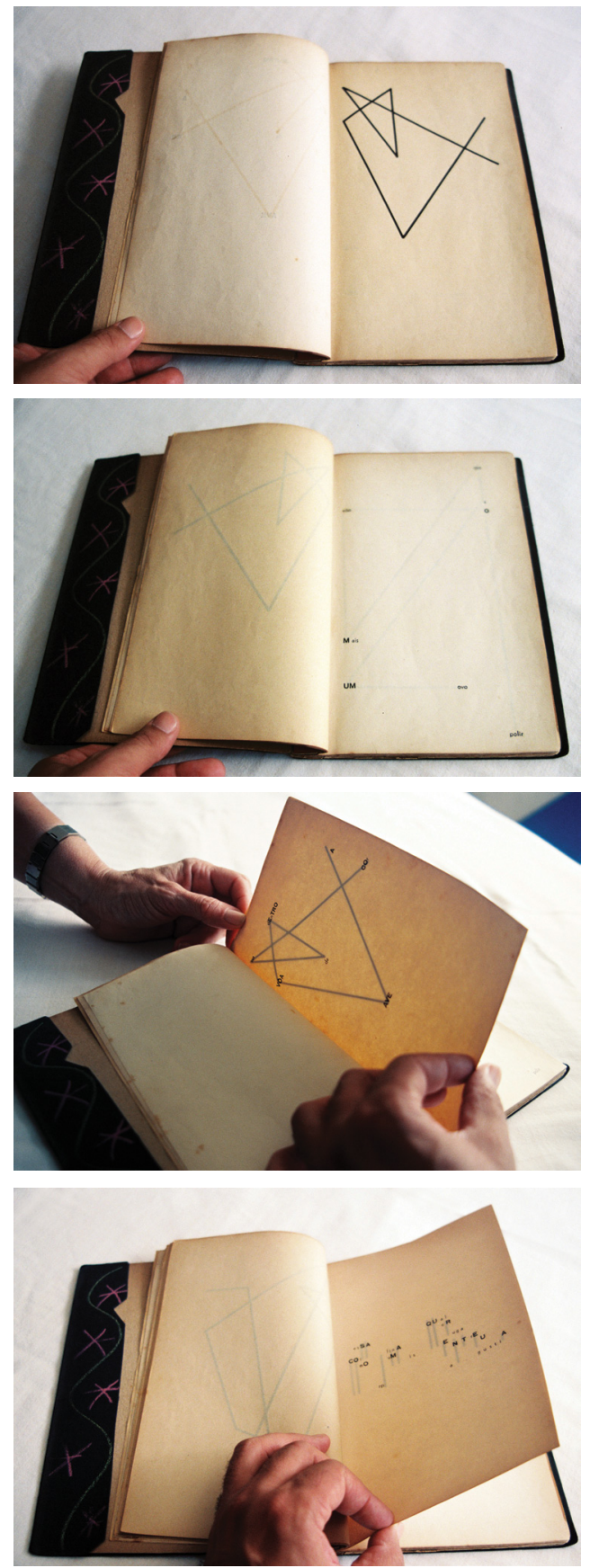

Wlademir Dias Pino, A ave, 1956.

${ }^{39}$ Originalmente, "Dias Pino", nome composto, sem hífen. O artista abandonou este uso. As páginas de rosto de $A$ ave, 1956, e de outros trabalhos registram "Dias Pino". O hífen passaria a ser usado com a atuação no movimento Poema-Processo (informação do artista). Aqui é registrada a grafia original. 
de trezentos exemplares, sendo executado parcialmente em tipografia e parcialmente com desenhos a nanquim. O miolo é composto por páginas não numeradas, com papéis brancos (a maioria) ou coloridos, presos à capa por grampos (prendedores latonados). A capa é de cartão colorido, coberta com uma sobrecapa preta, onde está recortada (vazada) a sugestão geométrica das letras do título em cortes retos e agudos. Verso e orelhas da contracapa têm suas inscrições a giz de cera. As páginas sofrem três tipos de intervenção: bidimensional gráfica, através da impressão tipográfica dos textos; bidimensional plástica, através dos traços retos a nanquim; e tridimensional plástica, através dos furos circulares nas páginas. O papel branco é bastante delgado, propiciando uma certa transparência. $\mathrm{O}$ papel colorido não foi especialmente encomendado. Era o disponível na cidade ou sobras da gráfica.

A leitura de $A$ ave se dá a partir do jogo com seis frases motivos: 1) A AVE VOA DEnTRO de sua COr; 2) polir O VOo Mais que A UM ovo; 3) que taTEar é SEU ContORno?; 4) SUA agUda cRistA compLeTA a solidão; 5) assim é que ela é teto DE SEU olfato; e 6) a curva amarGa SEU Voo e fecha Um TempO com SUa fOrma. As palavras são impressas com maiúsculas e minúsculas com a previsão de nova e futura atribuição de função aos caracteres, permitida pela leitura sugerida pela leve visibilidade dos traços negros da página seguinte, ou dos furos da página anterior, tudo dependendo do momento
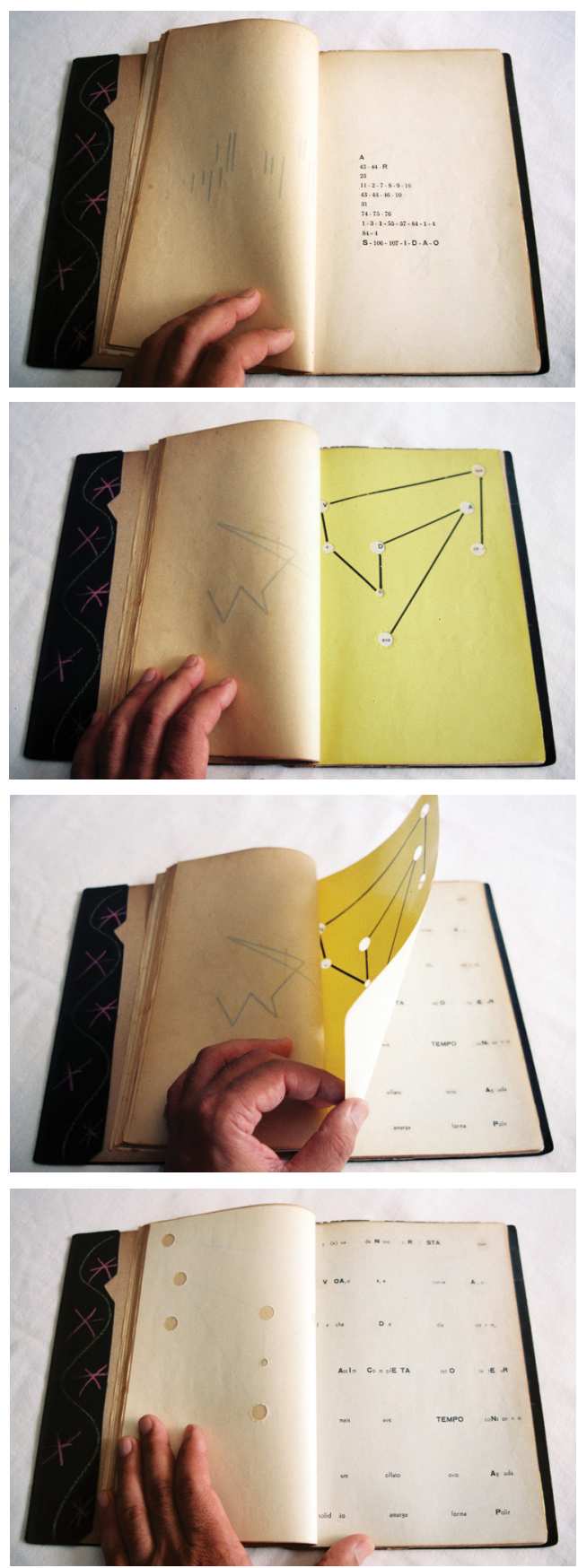

Wlademir Dias Pino, A ave, 1956. sequencial em que se está no livro. São necessários o uso concreto da percepção visual, da memória das páginas (ou ocorrências) passadas, da premonição (antevisão) do que está por vir, e do raciocínio matemático que seja formado por considerações tanto geométricas como estatísticas. Novas frases são geradas ou propostas: "a ave voa 
reto como um corte a altura de seu gosto" ou "voa até a morte alta do gesto". No final, por esgotamento de caracteres, as páginas serão imaculadas, sem impressão, sem violação. A página é um apoio (suporte) e uma separação.

Para Pino, o branco se dissolve em transparência, e a transparência total é a perfuração. Sua referência é Malevitch, mas com a temperatura tropical de uma região onde o fagismo é uma regra. Em uma poesia de 1951 essa atenção é evidenciada (citado por Darcy Gomes Neto em Arruda, 1998, p.8).
A Garça p'ra se esconder numa distância de estrela vem ficar na frente
da Faixa mais branca da areia [...]
A areia é movediça e a garça desaparece na brancura
$\mathrm{Na}$ cor branca da nuvem errante a garça de asas fechadas, desaparece, imóvel.

Ideias semelhantes ainda estão presentes em uma declaração dada a Frederico Morais, para artigo sobre a manifestação Arte Pública no Aterro, em agosto de 1968 (reproduzido em Wlademir..., 1982, p.125).

Quero fazer uma arte móvel, mas principalmente, para o músculo do homem. Uma arte que tenha rigor, mas de uma geometria do acrobático. $\mathrm{O}$ desencadeamento do lúdico, mas obedecendo uma ordem biológica. Uma expressão corporal, mas sem representação. Assim é que ao correr dentro do labirinto branco, o homem se sacode interiormente (já
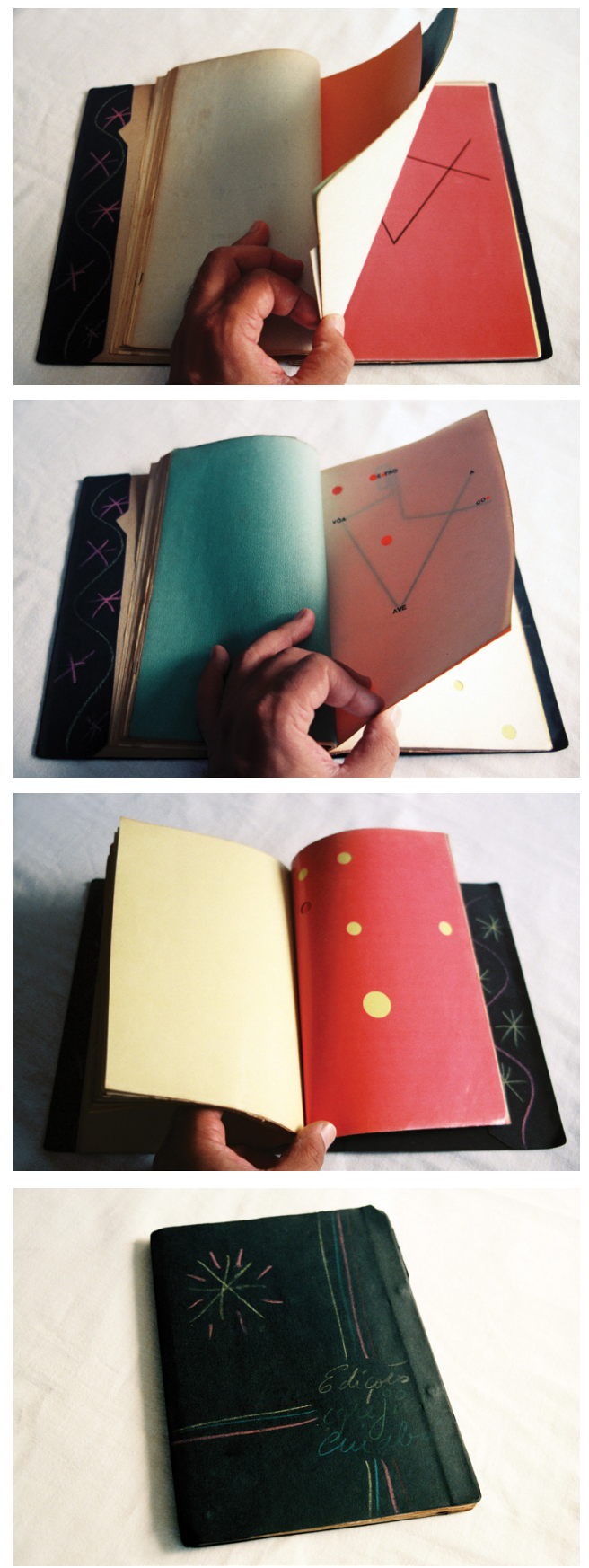

Wlademir Dias Pino, A ave, 1956. independente da "obra de arte"), com os músculos em sintonia com a respiração. Uma arte olfativa, mas, principalmente, respiratória. Labirinto branco é um poema com a brancura do papel e com as transparências de suas perfurações. É um outro nível de leitura, um outro ato de virar das páginas. 
$A$ ave foi impresso no Estado do Mato Grosso. Embora nascido no Rio de Janeiro, Pino viveu algumas décadas em Cuiabá. Esse é um dado importantíssimo para entender sua vida num ponto cego da cultura, no qual a poesia não é mais literatura, a atividade artística se confunde com a comunicação social, e a prática, que virou conceito, vira processo. A postura fria da arte concreta talvez fique mais natural num mundo urbano integrado à Europa. No Centro-Oeste brasileiro ela seria um abcesso. No início dos anos 80 , por exemplo, você sabia que estava chegando a Cuiabá ao parar para abastecer o carro na única estrada (recém-asfaltada), se espreguiçar após horas atravessando cerrados, olhar para o céu e ver um bando de araras-vermelhas passar voando, livre. $\mathrm{Ou}$ ao saber que as obras de um edifício foram interrompidas na fundação porque os operários acharam resíduos de ouro, e a empreiteira está decidindo se vale a pena continuar ou iniciar uma mineração. Ou ver na televisão que garotos acharam um jacaré numa vila próxima, bem mais comprido do que o seu sofá, fizeram uma grossa coleira de

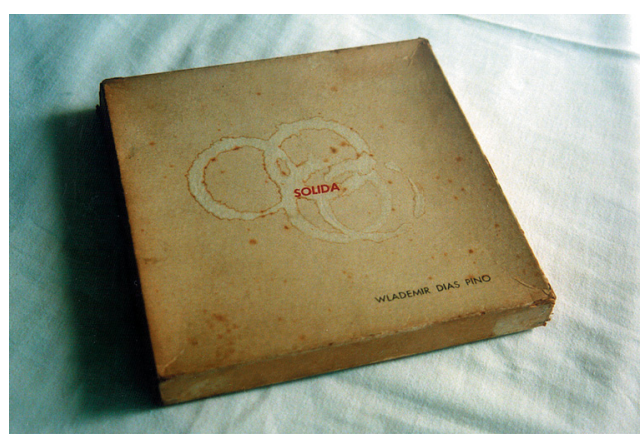
arame e agora passeiam com ele, brincando de assustar os outros. Apesar de encantadora, Cuiabá não estava nos principais roteiros turísticos. Nas últimas décadas do século XX seu perfil foi duramente ameaçado pelas migrações para oeste, vítima de uma classe média ansiosa por erigir seu ideal urbano. Mas para quem cria fica difícil contornar ou abdicar da identidade orgânica e assumir integralmente o cerebralismo.

Além disso, enquanto no Rio tenho uma atitude de vanguarda, nosso comportamento aqui é essencialmente político/literário. [...] Precisamos conceituar nossa identidade para reanimar os que se deixaram abater por essa invasão bárbara que ainda estamos assistindo. (Wlademir..., 1982, p.49)

Ou:

Somos um povo assimétrico. A simetria só aparece nas medidas da economia. Cuiabá nasceu rente ao chão. Irregular. Do veio de ouro irregular. É uma cidade plantada. Daí nosso enrosco. (p.123)

Esses e outros motivos fizeram do livro-obra ou livro de artista ou livro-objeto de Pino marginal tanto à poesia como à arte. Marginalidade maior ainda por ele ser um 


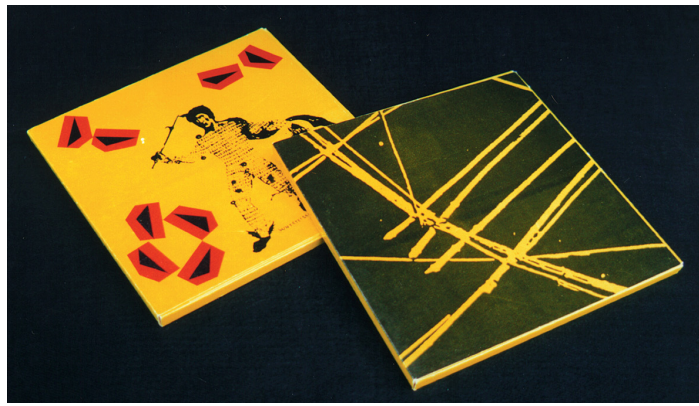

Wlademir Dias Pino,

Naquele futuar das escritas: caligramas

e Escritas arcaicas (também aberto), volumes 437 e 447 da Enciclopédia Visual, s.d.

dos pioneiros de uma forma de arte que ainda estava por ser identificada, teorizada e apresentada ao público.

$A$ ave responde ao lugar social da vanguarda. Numa primeira instância verificar-se-á que a lógica interna de sua estrutura exige o manuseio contínuo do objeto/livro. $\mathrm{Ou}$, como diria Alvaro de Sá, sua lógica apresenta uma rede de funcionalidades explicável ao longo de um uso criativo capaz de transformá-lo (o objeto) através do virar de páginas. Esta lógica, a de um produto para ser gasto no ato da leitura, obedece a uma seriação controlada pelos componentes formais do poema. Isto quer dizer que o livro poderia ter as folhas soltas, por exemplo, sem se propor a ser uma obra circular ou permutável, visto que a seriação (das matrizes, das cores, das texturas, das perfurações) organiza estruturalmente o seu processo e, organizando-o, descortina-o inteiro para o uso do leitor. (Cirne, 1975, p.36-37)

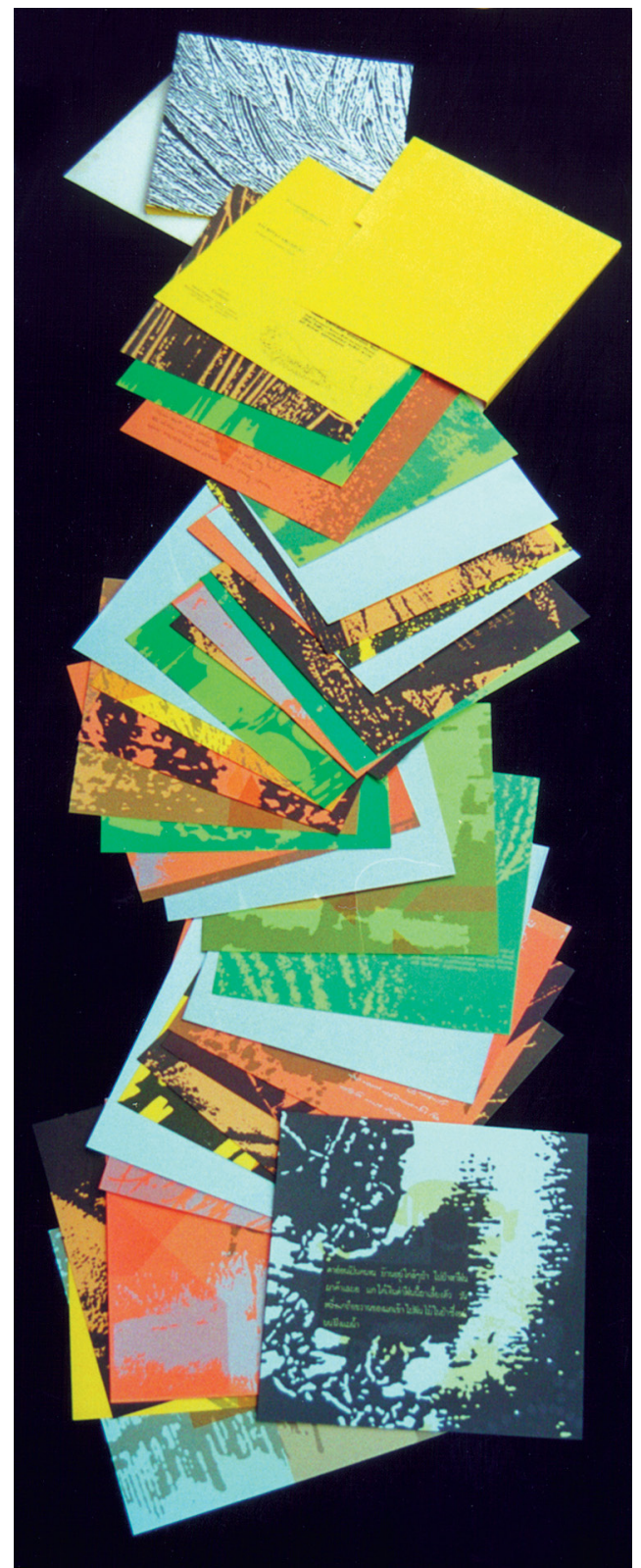

$A$ ave tem estreitos vínculos com o códice porque é uma construção linguística e matematicamente consciente de si como tal. Caso fosse necessário, Pino não hesitaria em optar por páginas soltas, como em Solida, exposto em 1956 e em 1962 executado na forma de caixa em serigrafia. Essa versatilidade encantou Ulises Carrión, que apontou Pino como um dos poetas concretos de primeira hora a reconhecer que um livro não é o texto impresso, mas uma sequência de páginas. E deixou um elogio: "O brasileiro Wladimir Diaz-Pino [sic] mostrou-me, durante minha visita ao Brasil em 1978, alguns 

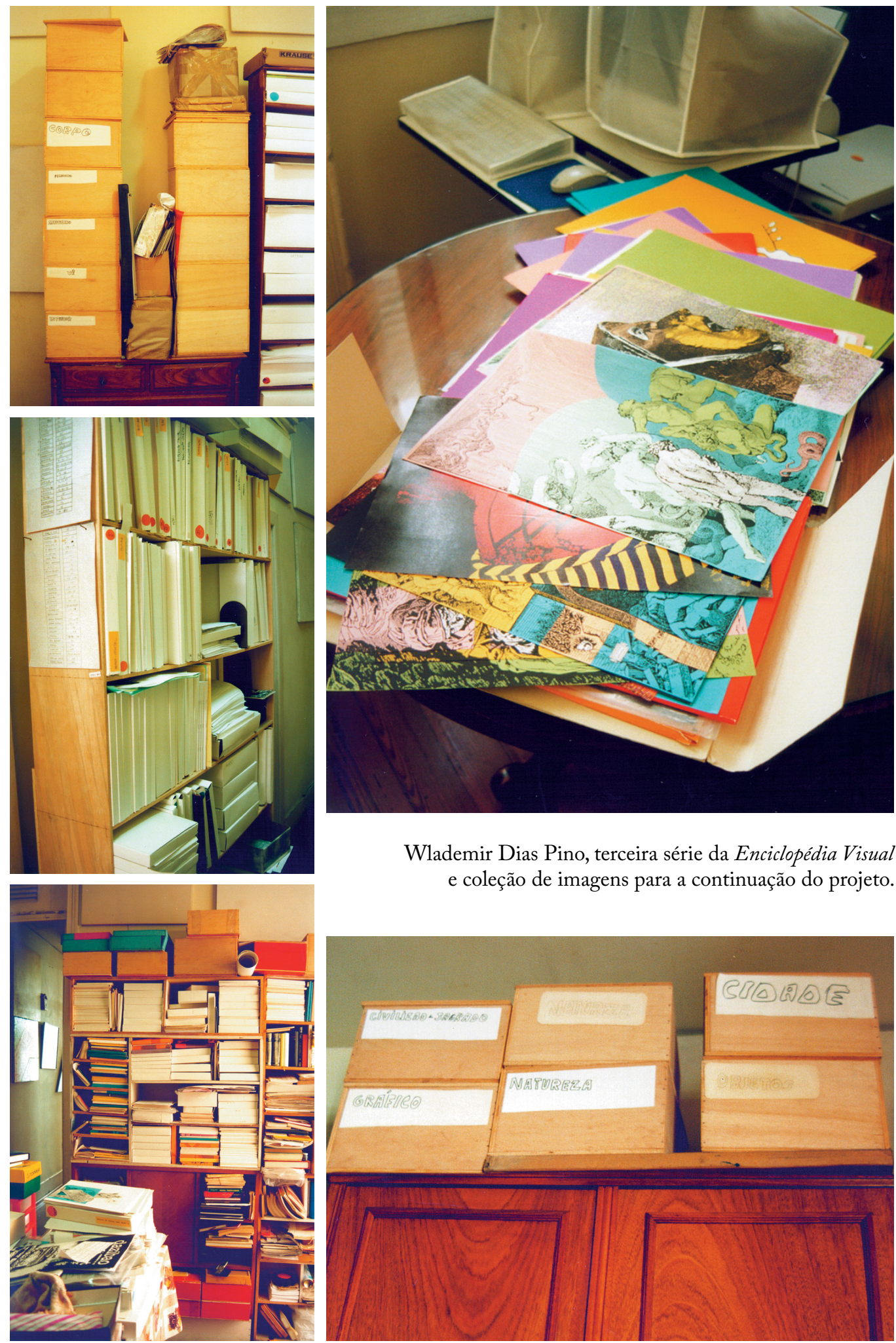

Wlademir Dias Pino, terceira série da Enciclopédia Visual e coleção de imagens para a continuação do projeto.

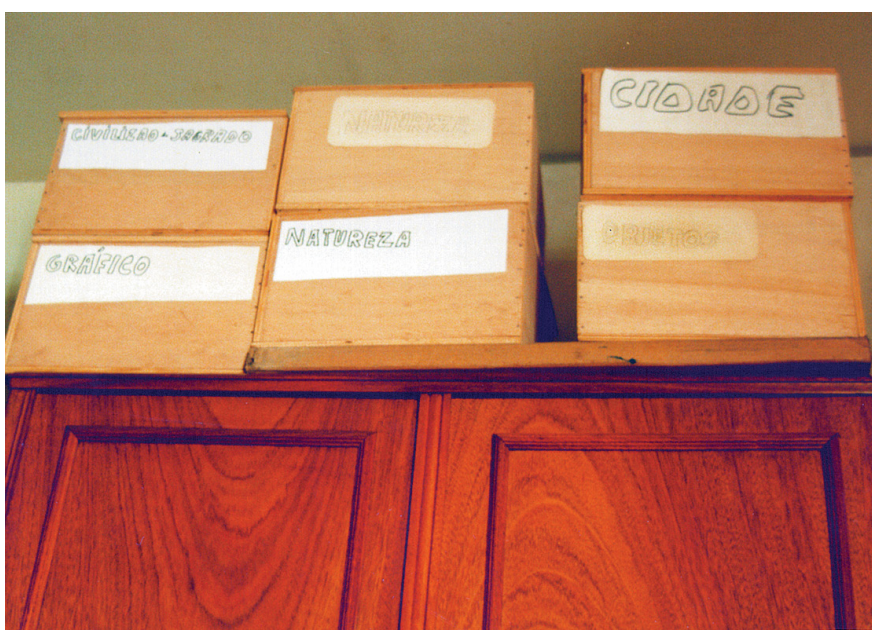


de seus primeiros livros (infelizmente eles estão agora esgotados). Eles são alguns dos melhores e mais bonitos livros-obra que eu já vi." (Bookworks revisited, publicação original em 1980, republicado em Carrión, 1997, p.71 e 166)

Mas se a primeira forma que nos vem à cabeça ao pensarmos no livro é o códice, a primeira função é a de guardar informação. E é sobre esse ponto de vista funcional que

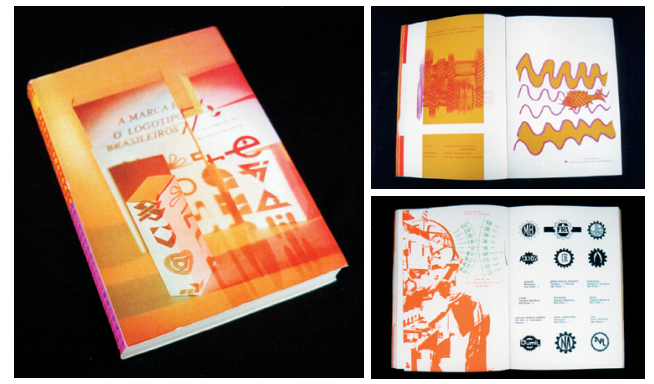

Wlademir Dias Pino e João Felicio dos Santos, A marca e o logotipo brasileiros, 1974. Pino vem construindo seu atual projeto,

a Enciclopédia visual, originalmente com a colaboração de João Felício dos Santos (falecido recentemente). A Enciclopédia... é tida por Pino como uma ação social, uma forma de infiltrar a imagem no mercado cultural através de seu uso agregado à informação didática. Esse processo está ligado a sua mais profunda ideologia, um artista que aprendeu a ler nos jornais impressos da gráfica de seu pai antes de saber escrever. Ele mesmo imprimia nas oficinas da gráfica da Universidade Federal de Mato Grosso quando os funcionários demonstravam desinteresse, descuido ou incapacidade técnica. Máquinas consideradas problemáticas como a Solna 125 (usada na impressão da Enciclopédia...) não eram um desafio, eram uma parte integrante da criação. O volume inicial (ou fundador) da Enciclopédia... foi lançado como um livro comercial, $A$ marca e o logotipo brasileiros, em 1974. Tem um formato de livro grande $(26,5 \times 18,5 \mathrm{~cm})$, mas as páginas não são numeradas, apesar de serem mais de trezentas. É uma brochura costurada colorida, mas não com seleção de cores (como seria esperado), mas com cores chapadas puras (tintas prontas), normalmente duas impressões por página ou, quando apenas uma, o preto. Parece um catálogo de logotipos, mas ultrapassa isso em muito, já que tem uma infinidade de colagens obtidas por alto-contraste ou fotocópia, com o favorecimento do procedimento offset. De fato ele está longe de ser uma obra didática de comunicação visual nos moldes tradicionais, como certamente seria enquadrado pelo mercado livreiro.

Depois desse lançamento, Pino passou para a segunda etapa da Enciclopédia visual, agora graficamente mais livre. Conseguiu imprimir seis números, todos com técnicas offset semelhantes a $A$ marca..., mas agora em páginas soltas 20,8 x 20,8 cm. A partir desse momento, a Enciclopédia... será inteiramente sem textos, formada a partir de colagens, com o intuito de ser didática e trazer informação apenas visual. É um trabalho gigantesco de coleta e fotocopiagem para posterior reprodução colorida. Pino tem pronto todo o esquema para a sua continuação. Tudo: os assuntos, os títulos, os desdobramentos, a ordem mais indicada para publicação. Mas os originais não são perenes. Eles podem se modificar a qualquer momento, por adição, subtração ou rearranjo interno. As prateleiras de sua residência guardam centenas de pastas, todas classificadas e organizadas. Sua proposta é ad infinitum, com a pretensão de cobrir o conhecimento 
imagético universal. Entre os seis volumes impressos, por exemplo o de número 437 (!) versa sobre caligramas, o que está no mesmo grupo temático do volume 447, que é sobre escritas arcaicas. Seus títulos são Naquele flutuar das escritas: caligramas, sem data, e Escritas arcaicas, também sem data, Europa Empresa Gráfica e Editora, Rio de Janeiro. Além da terceira fase, já ultrapassada, a quarta propõe outro formato para beneficiar-se do uso da fotocópia colorida e, talvez, ser produzida e vendida por demanda, já que Pino não consegue patrocínio para o seu ciclópico empreendimento. É um trabalho de Sísifo: materializar a informação através do visual, a principal função da reprodução editorial, num mundo em que a visualidade é interminável.

\section{Sequestro e aliciamento da ordem e da função}

Afirmar que o livro de artista começa onde o livro convencional termina é uma inverdade. No sentido genérico existem obras bastante convencionais, da infância, digamos, da arte em livro, como os livros de pintor e os livros ilustrados. No sentido particular também existem livros comuns, como algumas brochuras conceituais. Mas aceitar a norma bibliográfica é uma exceção para o artista do livro. A maior parte da produção parece ignorar passivamente ou ativamente os parâmetros dos organismos reguladores da normatização da produção intelectual (no Brasil, a Associação Brasileira de Normas Técnicas). É provável que seja ainda mais interessante o deboche pela regra, se ele puder gerar uma ação artística renovadora. Não é revelador que bibliotecários internacionais tenham discutido como catalogar a inclusão ou não desses títulos em seus domínios? Ou que galeristas fiquem contrafeitos quando "seus" artistas gastam o tempo com projetos de obras que valem apenas dez reais a unidade?

A realidade do acervo à disposição do sistema das artes é hoje composta por dois grandes grupos dominantes. Um deles será visto mais adiante, o que é constituído principalmente pelos matéricos e/ou escultóricos, considerados como agressão ao conceito de livro. O grupo que interessa neste momento é o das obras gráficas ou plásticas que são e têm sido a maioria da produção, além de terem recebido a maior atenção dos pesquisadores. São livros-objetos e livros de artista em sentido estrito que pertencem quase exclusivamente ao mundo das artes visuais, e como tal se utilizam de suas ferramentas e de sua liberdade para constituir uma entidade composta por vozes diferentes que demonstram a preservação e a proteção das formas consagradas (mesmo as anteriores ao tipo móvel e as orientais), ou usam a inversão das regras de apresentação, do hábito de leitura e do manuseio. São formas consagradas como livro, além do códice, o rolo, a sanfona (ou gaita, ou concertina), a caixa (ou estojo, ou pasta) e o envelope com folhas soltas, a pasta de arquivamento, o caderno e outras apresentações compósitas. Lembro apenas que apresentação e função são coisas diferentes. Ser uma pasta é uma forma de apresentação, uma configuração (que poderá ter a função prevista de guardar elementos 
avulsos), e ser um álbum é uma função (que poderá ter a apresentação prevista para enobrecer seu conteúdo). Por si só isso já oferece um bom espaço de intervenção para o artista. Ou seja, jogar com "o que é" e com o "para que serve".

O furo, já vimos, pode ser considerado uma das possibilidades mínimas de intervenção plástica na página. Ou para artistas como Pino, a máxima transparência. Do ponto de vista gráfico (bidimensional), um dos primeiros elementos é o indicador de sequencialidade, normalmente a numeração das páginas. Um dicionário, a rigor, não precisaria de fólios, já que a sequencialidade pode ser deduzida pela ordem alfabética. $\mathrm{Na}$ verdade essa é uma conclusão equivocada, já que o fólio não só serve à consulta de uma obra pronta, como participa da maioria das etapas de sua confecção (ou você acha que um artífice gráfico lê o livro que está imprimindo ${ }^{40}$ É possível que, com atenção e zelo, os trabalhos saiam a contento, o que será mais facilmente obtido se o próprio artista gerenciar as diversas etapas. $\mathrm{O}$ fato é que o fólio é uma norma, com princípios de uso, que coteja a sequência de páginas e confirma o caráter narrativo dessa sequência. A violação de seu uso é uma das portas de entrada para a arte, veja-se os livros de Edward Ruscha, por exemplo (penso que o comentário fotográfico é um segundo

${ }^{40}$ Certa vez presenteei uma amiga com um exemplar do "cine-romance" La Jetée, 1993, de Chris Marker, cineasta experimental francês. O filme original, de 1964, uma antológica ficção científica conceitual, era todo em preto-e-branco e com quadros parados,
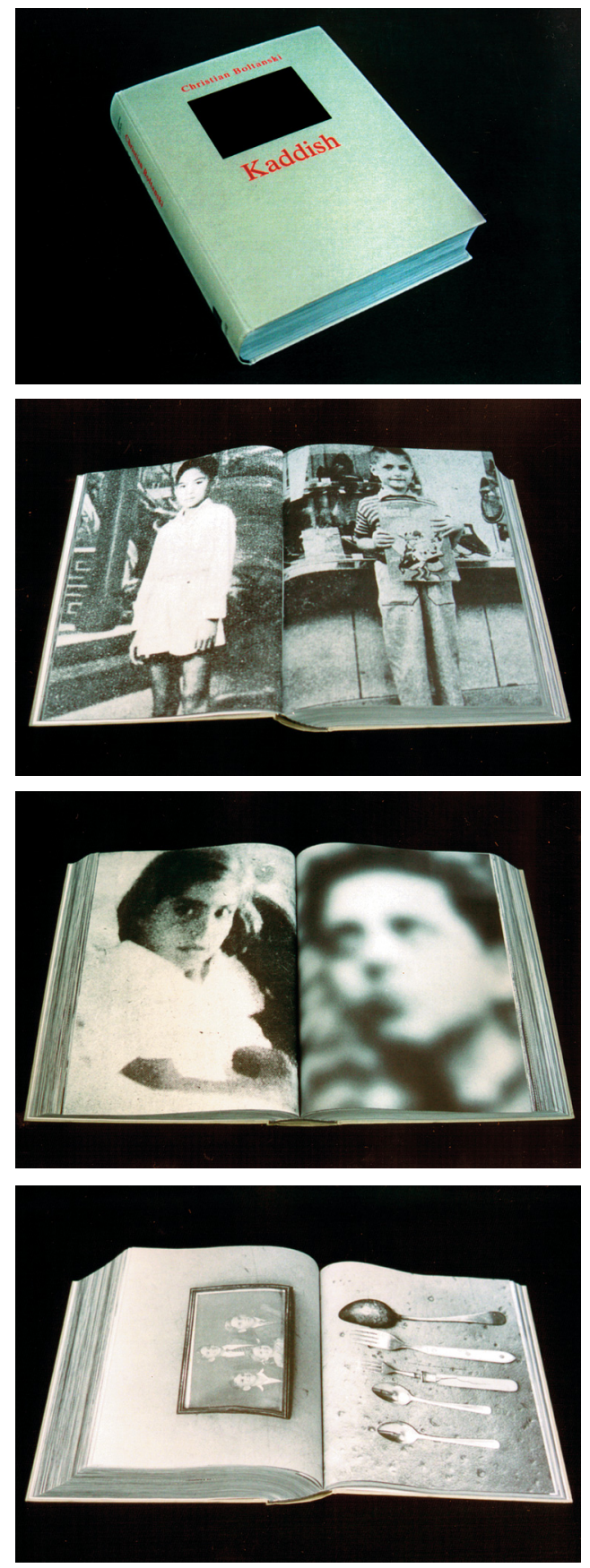

Christian Boltanski, Kaddish, 1998. como em uma fotonovela. Foi editado em livro com uma sequência (ou fotograma) por página, com a narração na posição de legenda, mas fora da imagem, em francês e inglês. O livro é sem fólios. A história é circular, com ciclos de ida e vinda no tempo. $\mathrm{O}$ problema do exemplar que eu comprei era a falta de um caderno e a repetição de outro em seu lugar. $\mathrm{O}$ livro foi trocado, com base nas lembranças que me sobraram do filme. Mas mesmo errado ele fazia sentido. 
aspecto). Livros sem fólio e sem algum indicador de sequencialidade deixam dúvidas prosaicas: será que ele é assim mesmo? E por que dessa maneira? O volumoso $\mathrm{Ka}^{-}$ ddish, de 1998, de Christian Boltanski, tem 1.160 páginas, divididas em quatro partes: Menschlich (humano), Sachlich (objetivo, realista), Örtlich (local) e Sterblich (mortal). Quase todas as seções são semelhantes, com reproduções ampliadas de rostos ou pequenas cenas. Ele não parece ter a menor sequencialidade, ao menos dentro de suas quatro partes. Entretanto, comparando, por exemplo, Sterblich, com a sua obra homônima avulsa (mesmas fotos), notamos que algumas imagens estão em ordem diferente. Fica o mistério: a ordem mudou de propósito ou foi dada liberdade ao setor de fotomecânica da gráfica? Existe ainda uma segunda diferença, a margem interna, que em Kaddish é preta e em Sterblich é branca, mas isso talvez não importe tanto aqui.

Se a paginação pode ser denegada, então ela também pode ser confirmada até a infinitude. O livro de Jan Voss, $M \ddot{o}-$ biusbandet, 1986, edição sueca, traz um desenvolvimento de seus desenhos contínuos ${ }^{41} \mathrm{em}$ que um seguimento de linha de um desenho formará o desenho seguinte, em situações cotidianas ou fantásticas. É impresso em duas impressões offset, em tons sutis, pelo próprio autor. A ideia do desenho crescente, em evolução (uma faixa de Möbius), antes ligada ao plano, é agora feita no espaço, "em altura e profundidade", segundo o artista, em forma adequada, onde "a edição inteira deste livro é o original". A
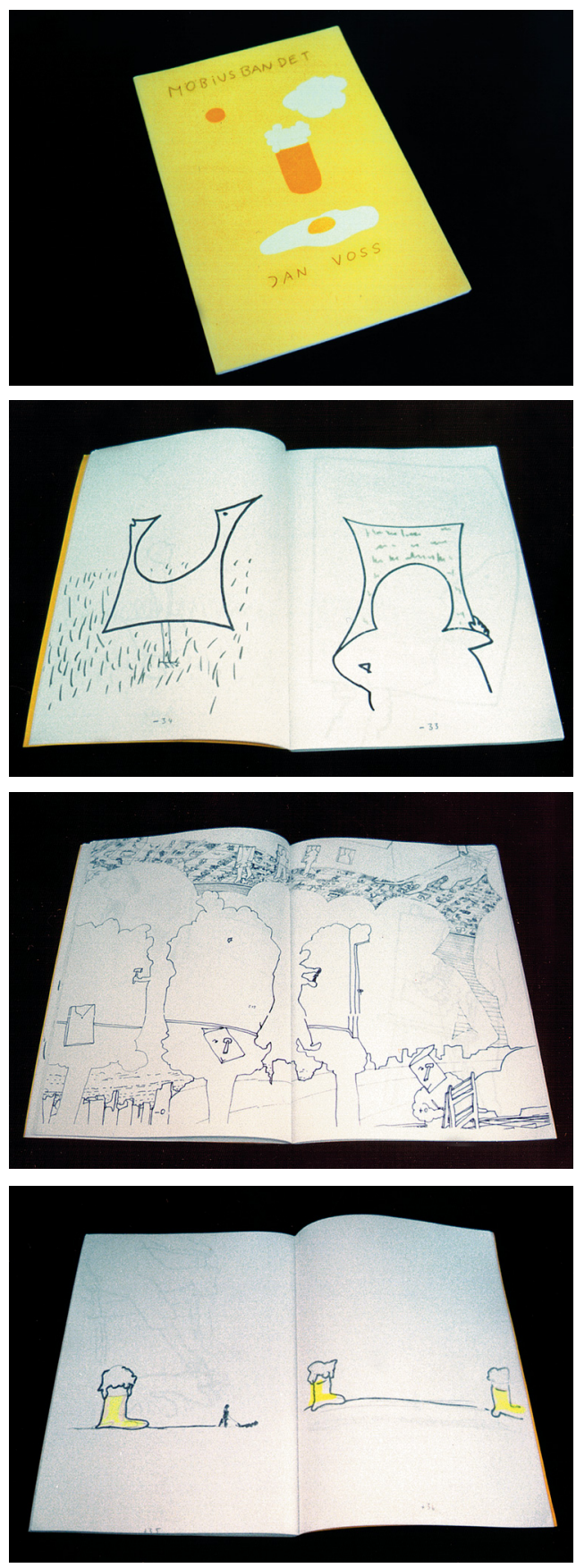

Jan Voss, Möbiusbandet, 1986. paginação do trabalho inicia na página -41 , indo até a +41 . $\mathrm{Na}$ impossibilidade de haver uma página nula numa obra grampeada

\footnotetext{
${ }^{41}$ Em inglês, growing drawings, em alemão, Wachsenden Zeichnung, e em sueco, växande teckning.
} 
(elas precisam ser pares ou ímpares), as páginas centrais são $-0 \mathrm{e}+0$, contendo um mapa de convergência. As informações escritas sobre a obra (apresentação e colofão) estão na página -32 .

Um exercício extremado de integração matemática da ordem das páginas com o conteúdo sígnico foi o realizado por Wlademir Dias Pino em Numéricos, 1960/1961. Ele tem 68 páginas “reais", mas sem fólios. A maioria delas são brancas, sem impressão, com algumas poucas com caracteres e números em azul, vermelho ou verde. Totalmente lúdica, a ordem é dada por uma compreensão que envolve adição, subtração, cálculo de quadrados, combinação, geometria, etc., propondo num objeto artístico uma série de charadas matemáticas. Tornou-se tão hermético que Alvaro de Sá elaborou, em 1969, um pequeno texto propondo uma forma de leitura (Sá, 1969). Dessa e outras maneiras, essa e outras propostas buscaram subverter a representação gráfica estabelecida pelo uso e pela norma para a ideia de continuidade.

Fisicamente falando, talvez o mais perseverante problema técnico imposto ao artista que queira fazer livros, tem sido a dificuldade de constituir a forma do volume pela união das páginas, em interdependência direta do processo de impressão (quando houver). Parece existir quatro caminhos principais: utilizar processos industriais, utilizar algumas técnicas artesanais, interferir em livros já existentes ou usar das formas alternativas sem costuras ou grampos.

A utilização de processos mecânicos e industriais tem sido a marca registrada dos artistas conceituais. Especialmente a fotocópia e, como passo seguinte, o offset,
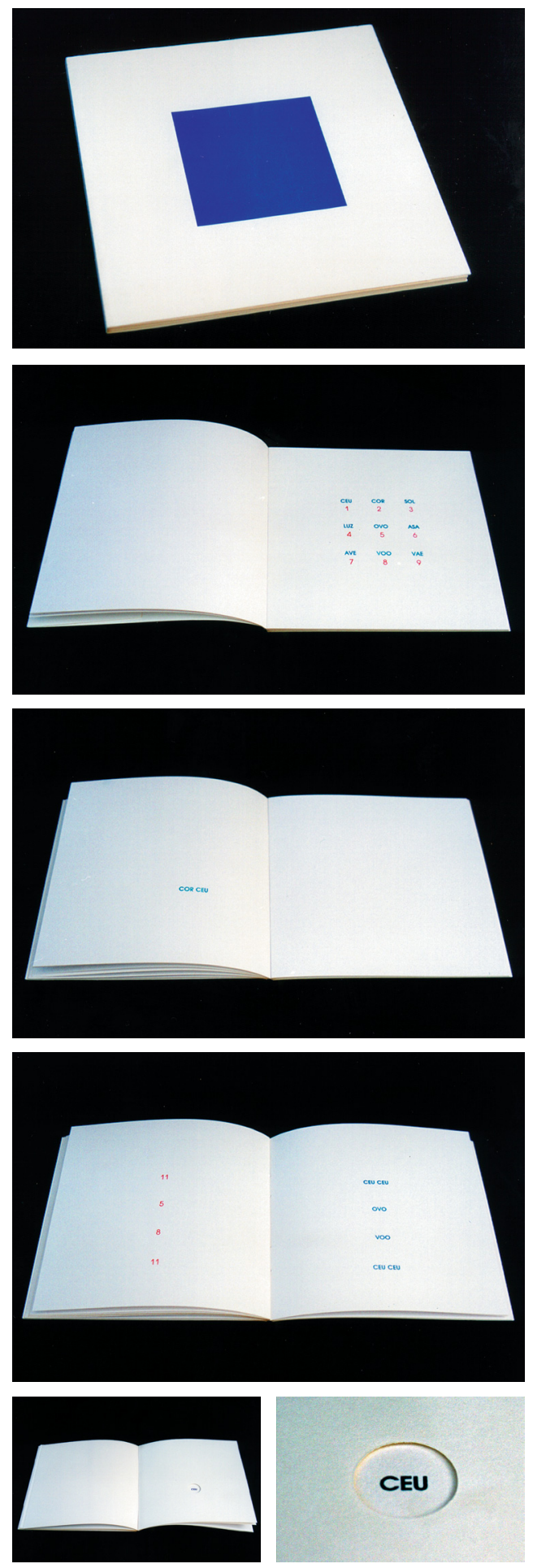

Wlademir Dias Pino, Numéricos, 1960-1961/1986. 
que não deixam marcas fundas no papel. $\mathrm{O}$ offset presta-se sobretudo para grandes tiragens não assinadas de nomes com compradores no mundo todo, como Sol LeWitt, Christian Boltanski, Lawrence Weiner ou Bruno Munari. Quanto ao uso da fotografia, onerosa e irregular na tipografia, passa a ser absolutamente banal. Entende-se aqui por reprodução fotográfica a reprodução de fotos, colagens e desenhos. Essa boa qualidade permite comentários visuais que perderiam definição em processos mais rústicos. Em 100 photographs which are not photographs of horses, 1995, de Claude Closky, todas as 92 páginas, mais as capas e o seu verso, são ocupados por fotos preto-e-branco de galinhas andando e ciscando no terreno. O ritmo talvez seja o principal elemento compositivo do volume, fazendo com que o humor da obra dependa em muito da textura obtida nas imagens, ricas em tons de cinza, que se perderiam em outros processos (com rotogravura essa qualidade também é mantida, mas é indicada para tiragens ainda maiores).

Mesmo banal, o processo offset tem-se mantido como a principal ferramenta de multiplicação em grande escala, "desglamorizando" uma parcela do mercado de
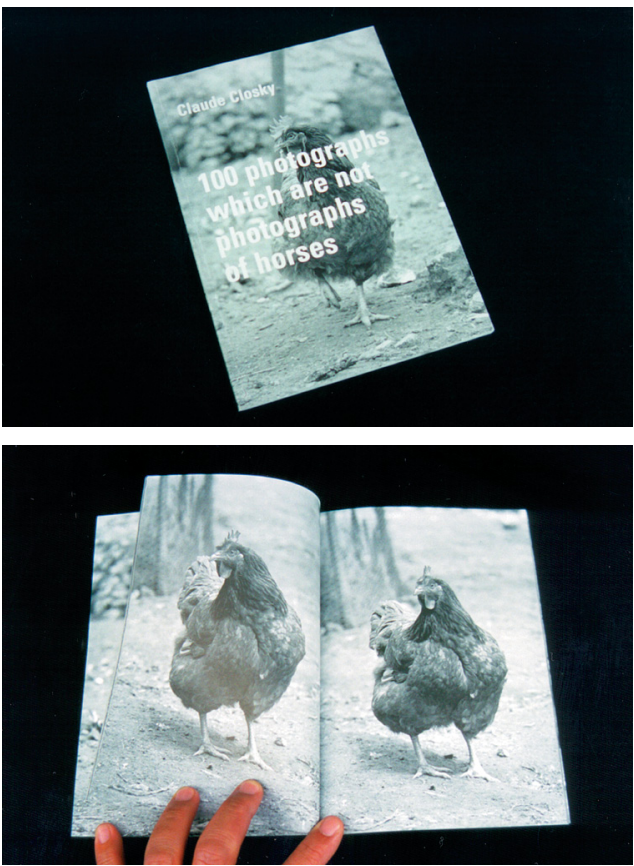

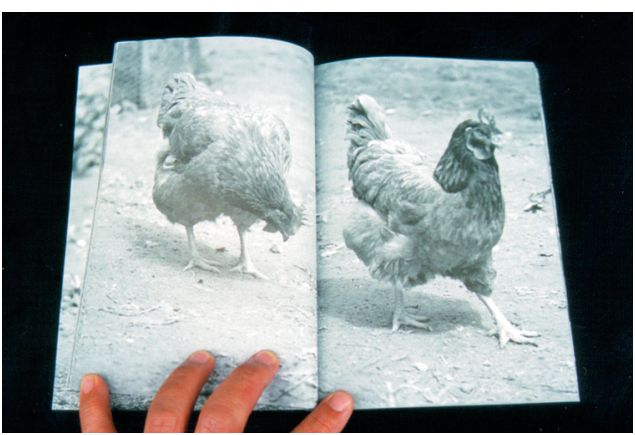

Claude Closky, 100 photographs which are not photographs of horses, 1995. arte.Pioneiros como Telfer Stokes e Helen

Douglas, que, da Escócia, produzem e imprimem nesse meio desde o início dos anos 70 , além de criar dentro do offset ou utilizando os seus limites, confirmam uma postura de integração com a técnica. Individualmente ou em colaboração, através de sua publicadora Weproductions, são um paradigma para o acabamento em brochura que explora o livro como objeto e como processo, além de integrar a palavra à fotografia, dando a ela (a palavra) o status de objeto (ver artigo de Clive Phillpot em Lyons, 1993, p.122-126). Para Stokes, "a ideia de caos e controle é uma força motivadora para fazer um livro", começando com a dualidade como conceito e chegando até a análise do livro como uma dualidade física, em que sua fisicalidade ("presença como objeto") convive com "a oportunidade para criar um mundo de ilusões dentro dele". A página teria, então, três camadas: dentro dela (como uma marca d'água), nela (como uma foto) e sobre 
ela (como os dedos) (Peixoto, 1996-1997, p.28-29). Para Douglas, fazer um livro é o seu modo de concretizar uma experiência de infância, de quando tinha 13 anos: "Naquela época eu tinha a necessidade de contar uma história". Sua relação com o livro é confessadamente passional e de preservação da função (Peixoto, 1996-1997, p.30-31).

Dentro da produção eu encontrei o armário interior.

O livro localizou esse lugar e propiciou a expressão segura de algo dentro de mim.

Segura porque como eu mesma e o armário, o livro não apenas abre como também fecha.

(Movimento físico - colocar algo precioso dentro de algo precioso.)

Ele parece um lugar seguro para colocar meus pensamentos e sentimentos.

Essa é a dinâmica inicial.

Mas existe outra.

Através da forma de publicação [...].

O livro é aberto,

(Movimento físico - abrir os braços)

e o que é contido, os pensamentos e sentimentos,

são expressos para outros, para o espectador um a um.

Nesses dois movimentos repousa minha fascinação com o livro.
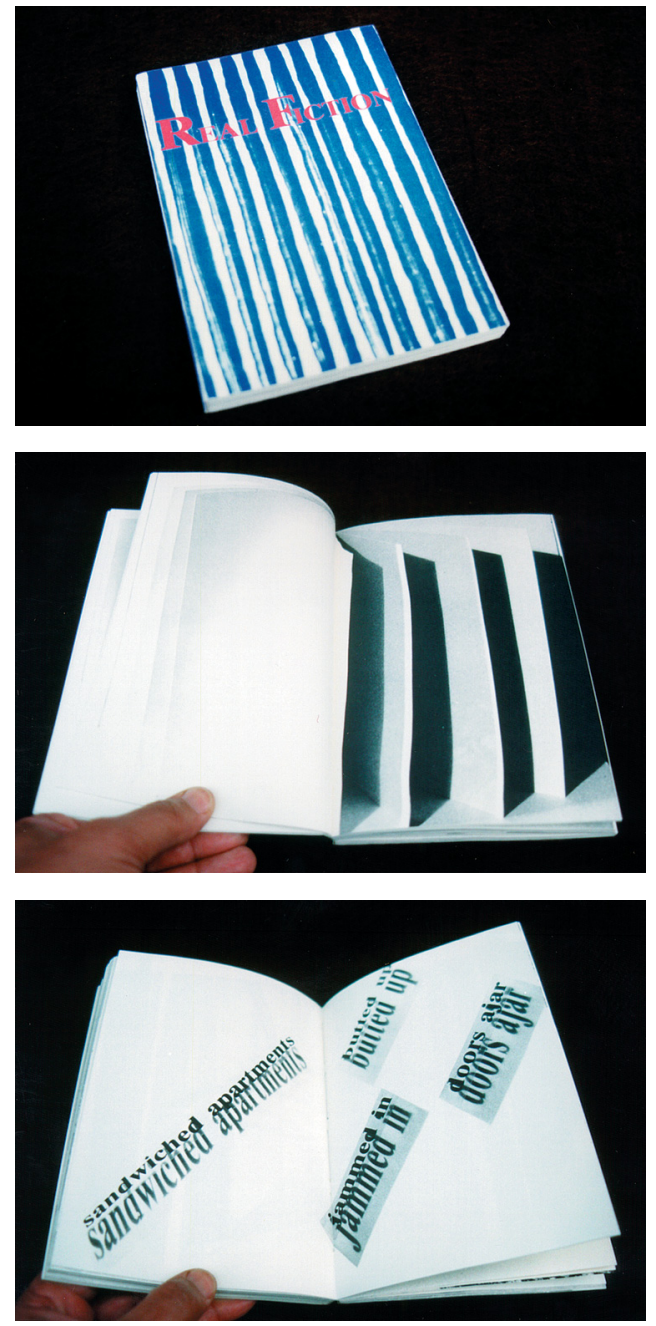

Telfer Stokes e Helen Douglas, Real fiction, 1987.

Esse laço com a conformação usual, bastante forte, não significa uma simples reiteração do precioso ou um gesto irrefletido de devoção. Aqui o precioso é intrínseco ao volume. O que também não implica recursos de valorização pela individualização do exemplar. Os livros de Stokes e Douglas não são numerados ou assinados. E a tiragem é aberta.

O acabamento primoroso do volume "de mesa" e a técnica sofisticada dos modernos sistemas de pré-impressão e impressão também podem ser instrumentos para a subversão do olhar. Recursos como a editoração eletrônica (ou melhor dizendo, edição visual e editoração gráfica por computador) possibilitam uma gama muito vasta de criações digitais, maior e mais complexa do que sonhariam os antigos amantes da colagem. Praticam-se intervenções em toda e qualquer imagem. Fotos e documentos antigos, 
depois de limpos e corrigidos de suas manchas e rasgões, ficam "mais verdadeiros". Não importa a praia, será, se quisermos, sempre dia de sol. A uma foto de um churrasco em família pode-se aplicar um filtro "impressionista" ou que a transforme em uma aquarela. São recursos kitsch que existem em qualquer programa de edição de imagem. Torna-se obrigatório um novo olhar, ainda mais inteligente, detetivesco, até porque pode-se deletar ou não as marcas do crime, escondendo o seu autor. Com isso mais as modernas tecnologias de impressão (e um bom patrocinador) pode-se mesmo parodiar a percepção de Merleau-Ponty, o sistema de valores na arte e até mesmo (por que não?) a própria eficiência tecnológica à disposição. É o que faz Waltercio Caldas através de Velázquez, 1996, um grande e falso livro de arte.

Ele é lindo, ele é um beaux livre. O formato é de primeira $(30,7 \times 26,8 \times 2,1 \mathrm{~cm})$, o papel é de primeira (cuchê fosco pesado), a encadernação é de primeira (capa dura revestida com tecido bordô e sobrecapa), a impressão é de primeira (a cores e no Chile) e a tiragem da primeira edição também é de primeira (1.500 exemplares). Ele é, ou
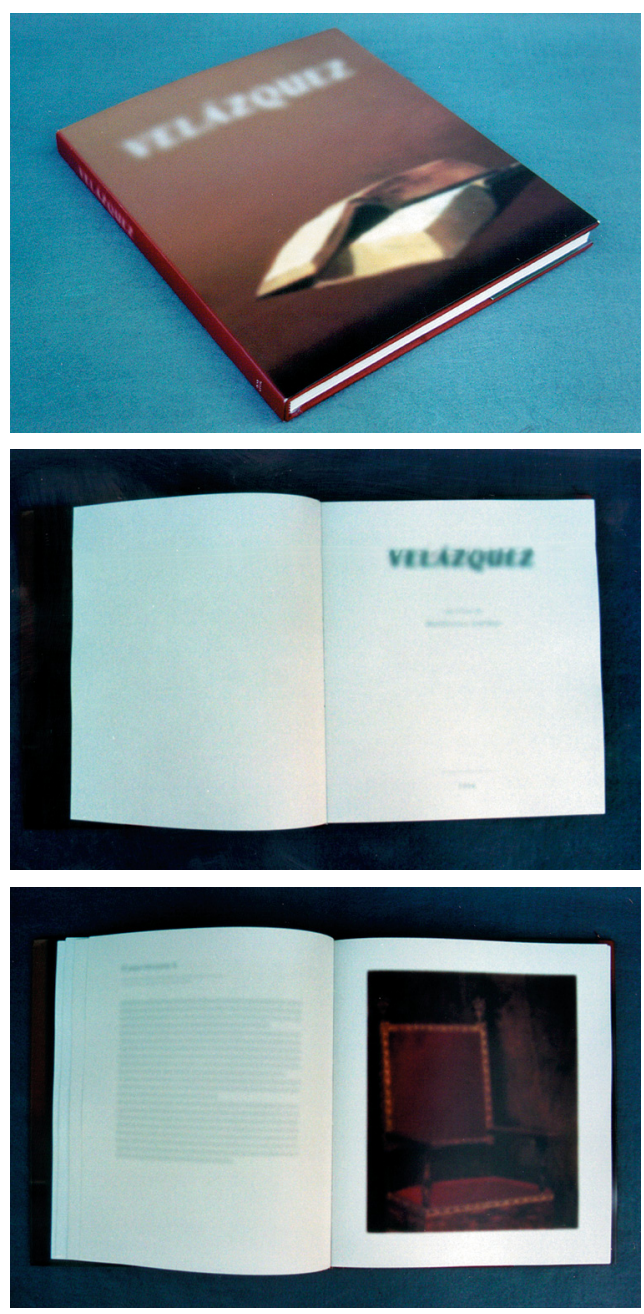

Waltercio Caldas, Velázquez, 1996. finge ser, um vilipêndio às obras de luxo, um livro de arte (sobre arte) alterado, sobre Velázquez. Numa primeira examinada, percebe-se que todo o livro é fora de foco. O desfoque é integral, incluindo imagens e texto, o que por si só os coloca numa falsa mesma dimensão visual. É importante considerar que a palavra fora de foco deixa de ser palavra, enquanto que uma imagem fora de foco permanece na sua condição de imagem. O procedimento de desfoque age como uma forma qualificadora e seletiva de obliteração num dado grau. Caso tenha havido uma proposta que envolva o tema da incomunicabilidade, então a obra instauraria um paradoxo. Partindo do princípio de que a leitura compreende dois estágios, "ver a palavra e levá-la em consideração de acordo com informações conhecidas” (Alberto Manguel, 1996, p.51), pode ser inferido que o desfoque que desmancha os parágrafos conduz a atenção e a interrogação para uma nova instância de leitura da página como ilustração de si mesma e do fantasma de ilustração nela contida. Lê-se e leva-se em consideração a dissertação oculta nas imagens denota- 
das e conotadas. Com um segundo olhar se percebe que todos os seres humanos foram apagados das pinturas reproduzidas, com a manutenção do fundo que, hipoteticamente, estava atrás delas. $\mathrm{O}$ exercício de memória que isso engendra é tão divertido quanto descobrir-se a si próprio a virar as páginas apressadamente para ver como ficaram As meninas. Não sei se existiu um livro original a ser transformado ou se tudo foi concebido do nada. Pouco importa. Talvez há alguns anos o trabalho envolvido fosse muito grande e exaustivo. Mas hoje o grau de dificuldade em alterar ou fazer novo é praticamente o mesmo. É possível que seja mais importante a penúltima página, onde todos os exemplares foram numerados e assinados pelo artista. Por quê? Seria por convenção ou seria um comentário crítico final? Que concepção teórica acompanha $o$ valor agregado por esse gesto?

Num evento de arte, o livro de Waltercio Caldas poderia ser exposto diretamente ao manuseio do público. Talvez furando-o e prendendo-o com uma correntinha a um suporte. Ele resistiria bem, afinal uma lista telefônica em local público aguenta um ano inteiro ou dois de uso. E mesmo que
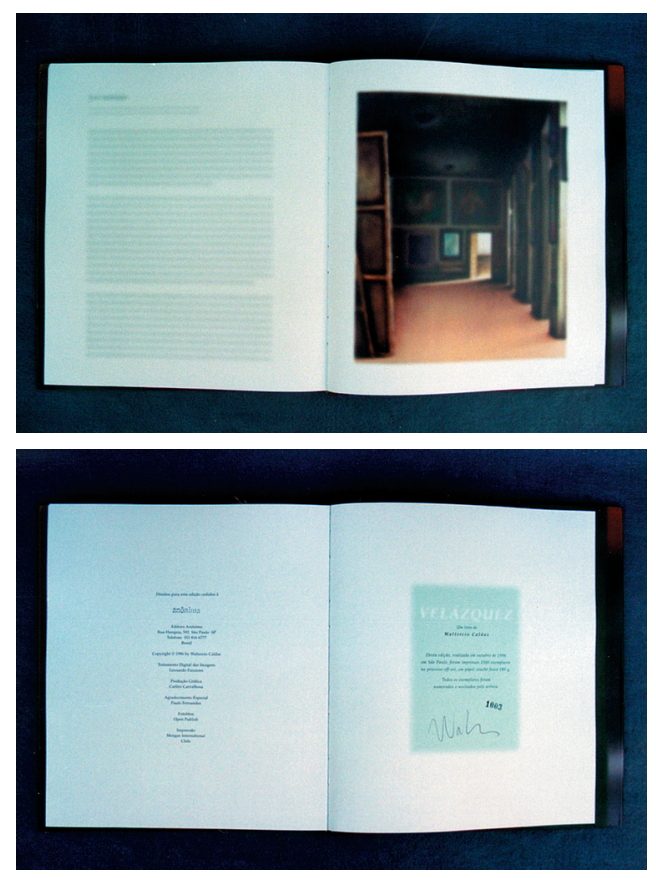
ele ficasse muito danificado, ao final de um

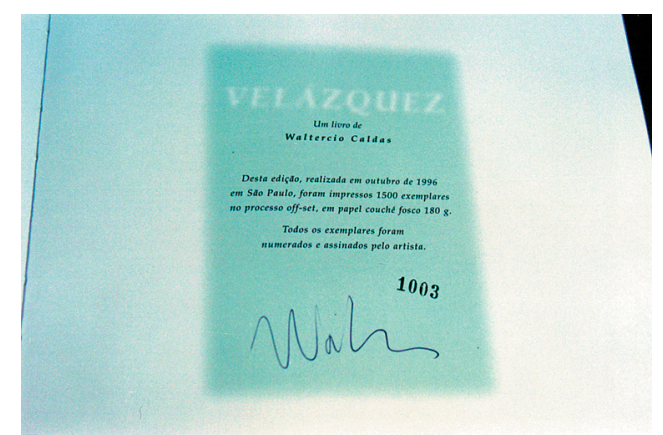

Waltercio Caldas, Velázquez, 1996. ano de exposição o custo seria apenas o de um exemplar, algo em torno de 80 dólares, preço final. Entretanto, durante o Panorama de Arte Brasileira 1997, do Museu de Arte Moderna de São Paulo, ele percorreu algumas capitais fechado em vitrinas. Como outro livro morto. Seria por precaução ou seria por mise-en-scène?

O offset ainda oferece uma valiosa colaboração passiva ao permitir a reprodução em fac-símile de obras esgotadas, de importância histórica, ou que têm seus originais em peças únicas. Isso disponibiliza o objeto de arte em grande escala, com grande território de distribuição. Estão disponíveis no comércio varejista, postal ou virtual livros como Jazz, original de 1947, de Matisse; Sobre 2 quadrados (ou про 2 -), original de 1922, de E1 Lissitzky; Mud book: how to make pies and cakes, original de 1983 (a partir de desenhos dos anos 50), de John Cage e Lois Long; O diário de Frida Kablo: um autorretrato intimo, originais de 1944 a 1954, publicado na íntegra postumamente a partir de $1995 \mathrm{em}$ 

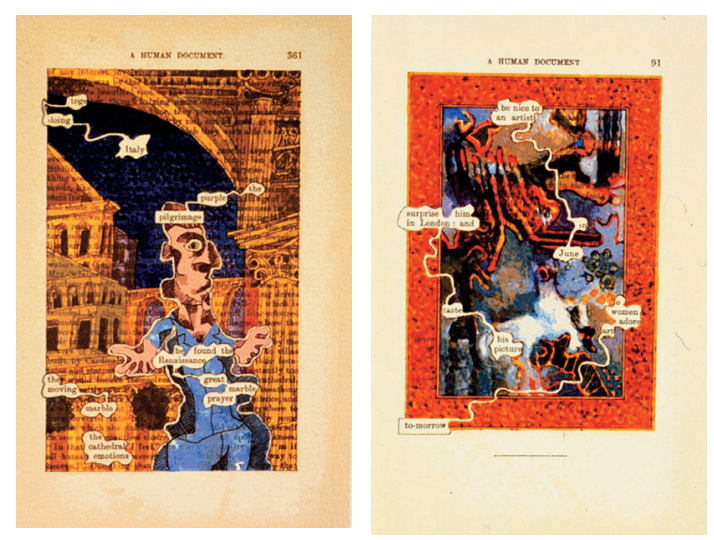

Tom Phillips, A humument: a treated victorian novel, edição de 1997, e páginas da internet.

diversos países, tornando-se um best-seller da área; e talvez o mais importante entre os fac-símiles contemporâneos, $A$ bumument: a treated victorian novel, original de 1980, de Tom Phillips. O último é mais do que uma reprodução. É uma obra em processo, iniciada em 1966, construída pela obliteração criativa e muito colorida das páginas de uma novela já existente, deixando livres palavras que geram novas ideias. Phillips prossegue substituindo páginas antigas por novas, mesmo na última edição disponível, de 1997, além de dispor atualizações na internet (www.rosacordis.com/humument). A bumument é um livro vivo.

Entretanto, se por um lado o offset escancara as portas tanto para o barato quanto para o refinado, por outro ele é extremamente gentil com o suporte. A impressão úmida e indireta é plana, não tendo a faculdade de criar qualquer tipo de relevo que não seja ilusório. Essa gentileza técnica, além da característica rotativa das máquinas, impede o uso de papéis muito grossos ou rústicos, devolvendo espaço para a tipografia e a flexografia. O próprio processo de impressão tipográfica pode ser utilizado como gerador de suas próprias cicatrizes. Drucker (1995, p.190) lembra esse fato ao comentar a obra de Ken Campbell, de páginas saturadas de tinta de impressão, que podem traduzir em termos gráficos qualidades de desfiguração, obliteração 

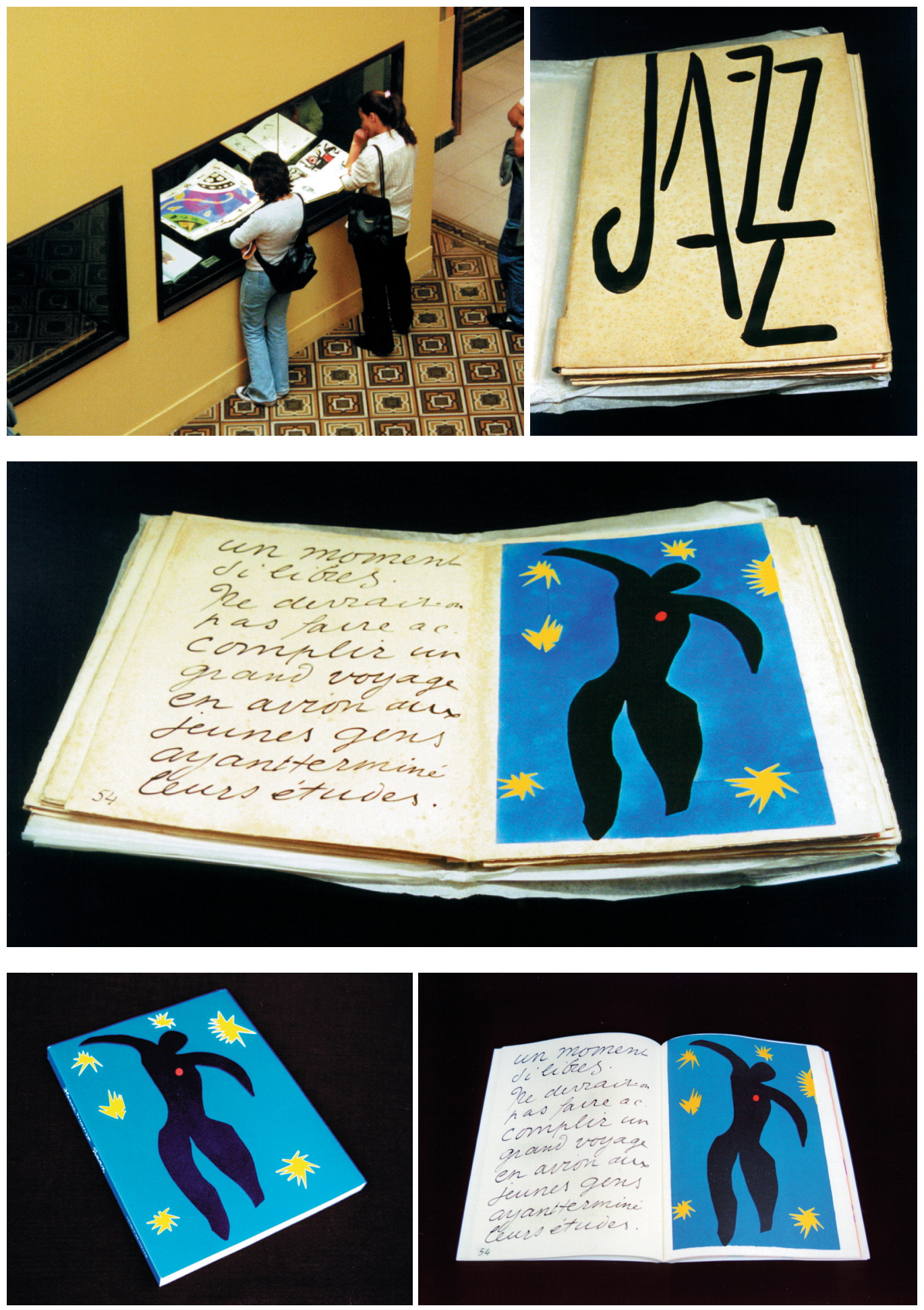

Henri Matisse, Jazz, 1947, em exibição no Museu de Arte do Rio Grande do Sul, 2000 (exemplar do acervo da Biblioteca Nacional, Rio de Janeiro). Embaixo, edição contemporânea comercial, fac-similada. 
e violência. Considerações complementares podem ser localizadas em apreciação de Rodney Philips, curador de uma mostra de Campbell. Apontando o uso de uma pesada prensa de provas Vandercook mesmo para a elaboração de imagens delicadas e brilhantes, ele nota que isso desmentiria a "sua gênese torturada" (Broken..., 1994). Para o mesmo prospecto, comentando o livro Skute Awabo, 1992 (tiragem de apenas doze exemplares), Julian Freeman diz que a obra "afirma e denega a Bíblia e Conrad igualmente. Em vez, chamas são vistas

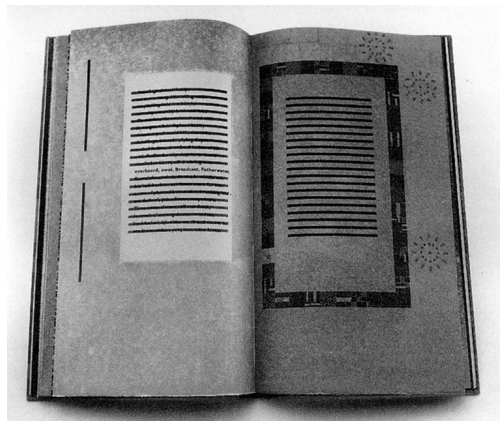

Ken Campbell, Father's garden, 1989

(Drucker, 1995, p.251). de relance entre suas páginas: luzes que, quando avançam, nem guiam, nem saúdam, mas que podem consumir ou cegar."

\section{Sequestro e aliciamento da aparência e da leitura}

Reitero que o problema do ovo e da galinha interessa pouco para esse trabalho. Polemizar sobre isso envolve outro enfoque e outros procedimentos historiográficos, embora isso venha ocorrendo nesta pesquisa, inevitavelmente. O que mais interessa é perceber o que constitui o fato, ou seja, que amostras de obras vêm frequentando as coletivas do gênero. E, por consequência, que considerações críticas as têm acompanhado. A demarcação do território de presença da arte no livro tem sido uma constante. El Lissitzky, depois de elogiar Sonia Delaunay-Terk, já tinha informado a existência de uma nova ordem em texto original de 1926.

Entre nós na Rússia o novo movimento iniciou em 1908 [...]. Esses não eram numerados, não eram cópias de luxo, eles eram baratos, não encadernados, brochuras, que nós devemos considerar hoje, apesar de sua urbanidade, como arte popular. Os camaradas Popova, Rodchenko, Klutsis, Syenkin, Stepanova e Gan dedicaram-se eles mesmos ao livro. [...] Nós sabemos que estando em contato com eventos mundiais e acompanhando o progresso do desenvolvimento social, que com a estimulação perpétua de nosso nervo óptico, com o domínio da matéria plástica, com a construção do plano e seu espaço, com a força que mantém a inventividade em ponto de ebulição, com todos esses recursos, nós sabemos que finalmente deveremos dar uma nova eficácia ao livro como uma obra de arte. Contudo, no presente dia e época nós ainda não temos nenhuma nova forma para o livro como um corpo; ele continua a ser uma capa com uma sobrecapa, e uma lombada, e páginas 1, 2, 3... (Citado por Brad Freeman em JAB 9, 1998, p.2)

E pouco antes, em 1920:

Construir um livro como um corpo movendo em espaço e tempo, como um relevo dinâmico no qual cada página é uma superfície portando formas, e a cada virada de página uma nova travessia para um novo estágio de uma estrutura singular. (Citado por Railing, 1991, p.37) 
O reverso da moeda é a regra ideológica (e às vezes mercadológica) que assombra as noites de projetistas gráficos, uma vez expressada por Aloísio Magalhães (1981, p.77): "tudo o mais é absolutamente relativo, porque entre ter um livro bonito, por exemplo, ou, na impossibilidade deste ser bem cuidado, tê-lo de qualquer modo é mais importante que qualquer coisa". Para um objeto livro tradicional (comercial e industrializado) a postura desejada pelo mercado deve estar a par com a tradição, sendo poucas as variações permitidas. $\mathrm{O}$ oposto se dará com o livro-objeto. Este busca sua condição de objeto ímpar pela individualização de seu visual e de sua relação com o espaço. As convenções devem ser, se não agredidas, ao menos transgredidas. Como, por exemplo, ao utilizar metal para narrar a vida de Cristo, ao invés da caligrafia, nas bíblias de Gutenberg, além de ter a pretensão dessa narração a partir de um país bárbaro, e não a "culta Itália" (Manguel, 1996, p.370, nota 17). Referindo-se a recusa do Duque de Urbino em aceitar em sua biblioteca de livros manuscritos a presença dos livros de Gutenberg (que o Duque considerava horríveis), Magalhães afirma "a necessidade que o homem tem de se ater às formas anteriores" e a "dificuldade que temos de romper com a tradição e inaugurar uma outra" (p.79). Buscando aceitação, Gutenberg teria tentado desesperadamente fazer com que seus caracteres fundidos parecessem com letras manuscritas. E todo gesto fundante que rompe com a tradição seria "de início um pouco grotesco".

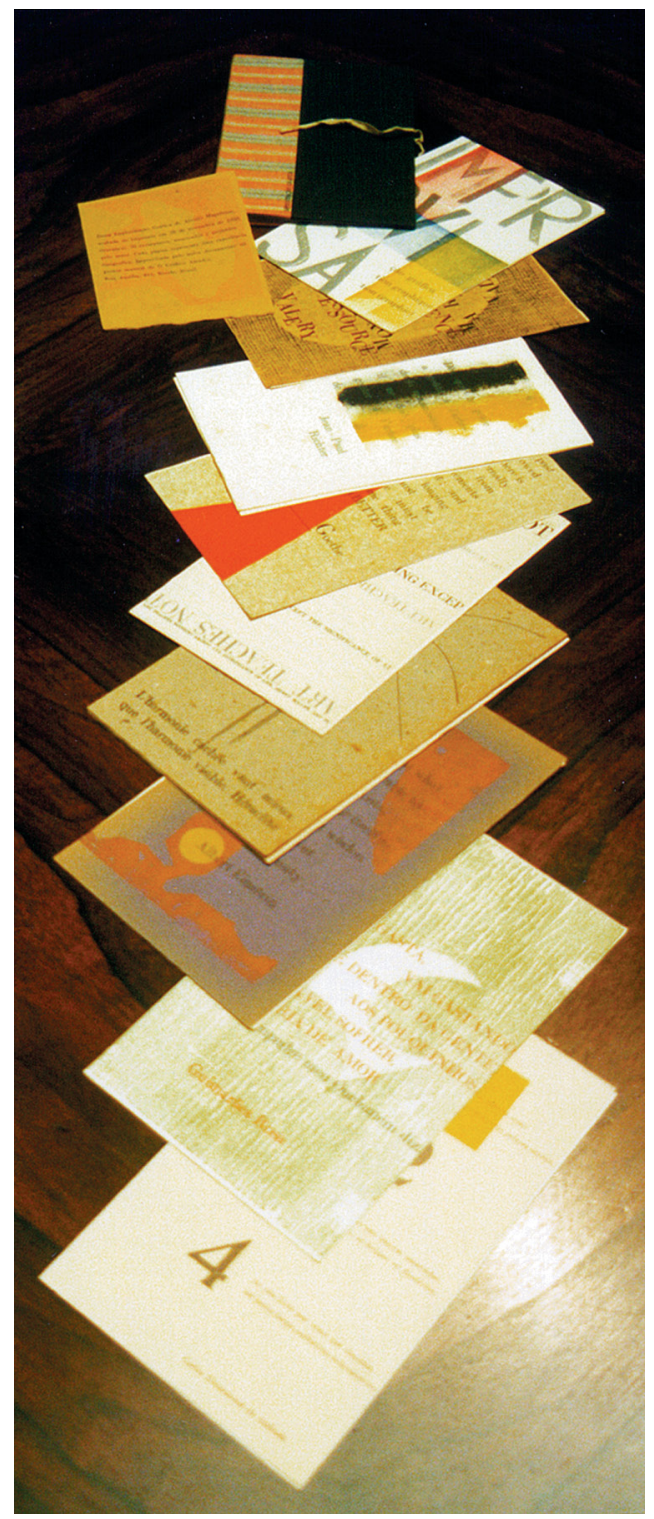

Aloísio Magalhaes, Improvisação gráfica, 1958 (acervo da Biblioteca Nacional, Rio de Janeiro).

Umberto Eco tem repetido que paralelamente à força da civilização da visão, prossegue a marcha da civilização da leitura, num certo processo de integração. Ele credita a permanência da literatura à existência da narrativa: "Ela não desapareceu. Ao contrário, expressa-se na sede de narrativas e na procura de jornais, de novelas, de televisão, do 
cinema e dos livros. Reina o desejo da narrativa". ${ }^{42}$ No livro de artista dos anos 90 pode ser detectada uma diminuição gradual da espacialidade poética e da razão sistêmica conceitual em favor de um certo argumento narrativo, muitas vezes prosaico. Isso num certo sentido atende à premissa mítica de obrigatoriedade de haver a relação com uma dada realidade.

A narrativa, no nível ofertado a partir do códice, apresenta a subordinação, de um léxico da fantasia, a um princípio de realidade - o nível real desta linguagem, ou seja, aquilo que é ofertado como verdade do ponto de vista da comunidade. (Mendonça e Sá, 1983, p.205)

Essa aproximação com o real se dá fisicamente pelo cenográfico ou pelo transformismo. Com frequência um livro de artista não é o que parece. $E$ às vezes se apropria da conformação exterior e dos padrões de estilo de outros objetos gráficos, tanto livros como assemelhados. É frequente, por exemplo, a simulação de livros infantis, ou o uso de seus estilos de ilustração, para tratar de temas como segregação racial, consciência política, condição da mulher e das minorias. Isso também facilita o ingresso da figuração com traços ingênuos. O acabamento vai da
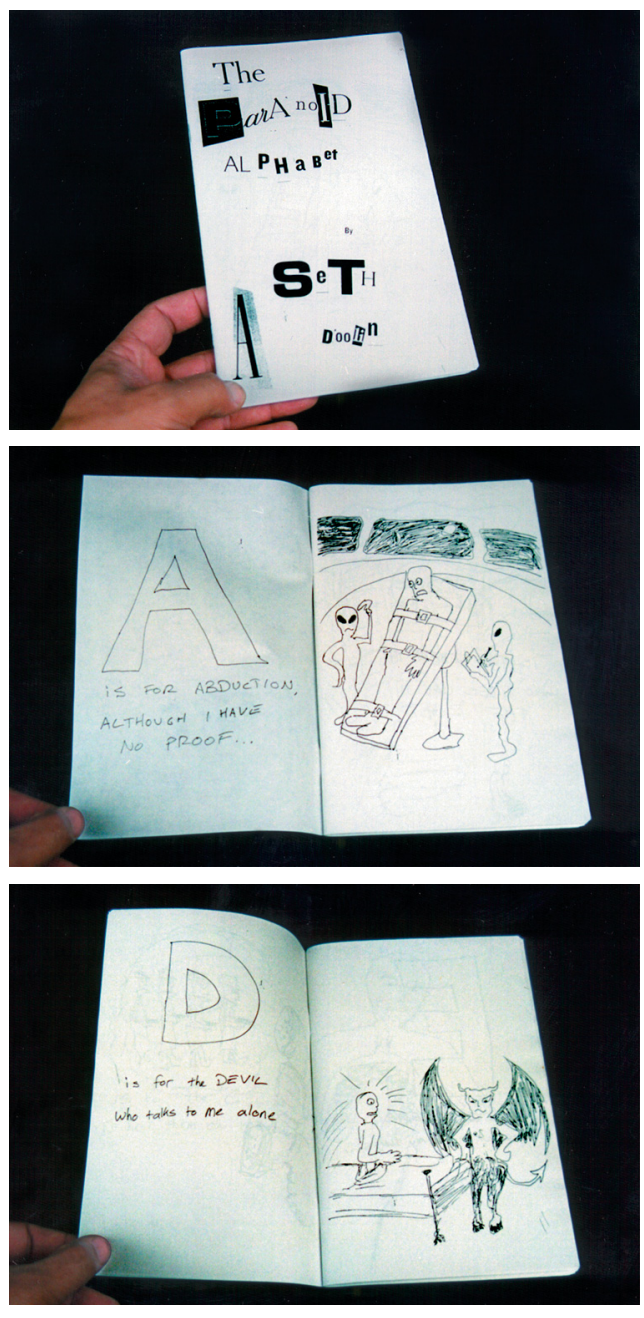

Seth Doolin, The paranoid alphabet, 1996. simples fotocópia até o uso de plásticos.

The paranoid alphabet, 1996, de Seth Doolin, é uma curiosa brincadeira em que para cada letra do alfabeto corresponde uma paranoia própria ou coletiva. Os traços lembram desenhos de humor, mas mais toscos. Tem 56 páginas em fotocópias, obtidas simplesmente pela dobra de quatorze folhas comuns, onde a primeira serve de capa, e grampeadas a cavalo. $\mathrm{O}$ aspecto geral é de uma produção pobre, mal-acabada, marginal, mas criativa e barata.

Tecnicamente mais sofisticado, Fingerprints, 1998, de Hiro Sugiyama, envolve outras técnicas na sua produção. Com formato quase quadrado, tem capa azul em plástico maleável (vinil), com impressão provavelmente serigráfica. O miolo é em duas

\footnotetext{
${ }^{42}$ Entrevista a Juremir Machado da Silva,jornal Zero Hora, Segundo Caderno, 28 de novembro de 1992, p.9.
} 
impressões, sendo vermelho e azul na página de rosto e na página do colofão, e preto e amarelo-claro (creme) nas restantes. As imagens são desenhos com grossas linhas pretas lembrando publicações infantis de colorir (o original é a lápis sobre base gessada). Os objetos cotidianos representados lembram a cultura pop, mas sofrem uma discreta deformação funcional, como em uma intromissão de relações inconscientes. A impressão em offset inclui as manchas e marcas de dedo do processo, o que dá à obra uma aparência "suja".

Esse travestismo avança por todas as configurações gráficas livro-referentes, aproveitando-se de cada particular estilo de redação ou apresentação. São relatórios e dossiês industriais, encartes de publicidade, folhetos turísticos, malas-diretas, manuais técnicos... Enfim, uma gama muito ampla de suportes para a palavra impressa que acompanha a imagem. Trata-se aqui de usar a retórica mais que a poética. Mas uma retórica plagiarística que proporcione acesso à aparência gráfica da obra, como um disfarce para outros discursos. Na maioria dessas ocorrências a função do texto é maior do que se poderia imaginar, em se tratando de obra de artes visuais. E também aqui o humor ou a ironia ganham espaço. Como em Diversões, 1986, de Jailton Moreira, um pequeno catálogo grampeado que traz em suas páginas a descrição quase taxionômica de engenhocas impossíveis, que têm a ambição de serem máquinas de provocar alegria. No título, as três letras centrais estão impressas de forma espelhada (o que era no sentido da direita passou para a esquerda).

Dentre muitos guias e manuais mais recentes, existem duas obras de custo ínfimo que têm formatação singela e leitura con-
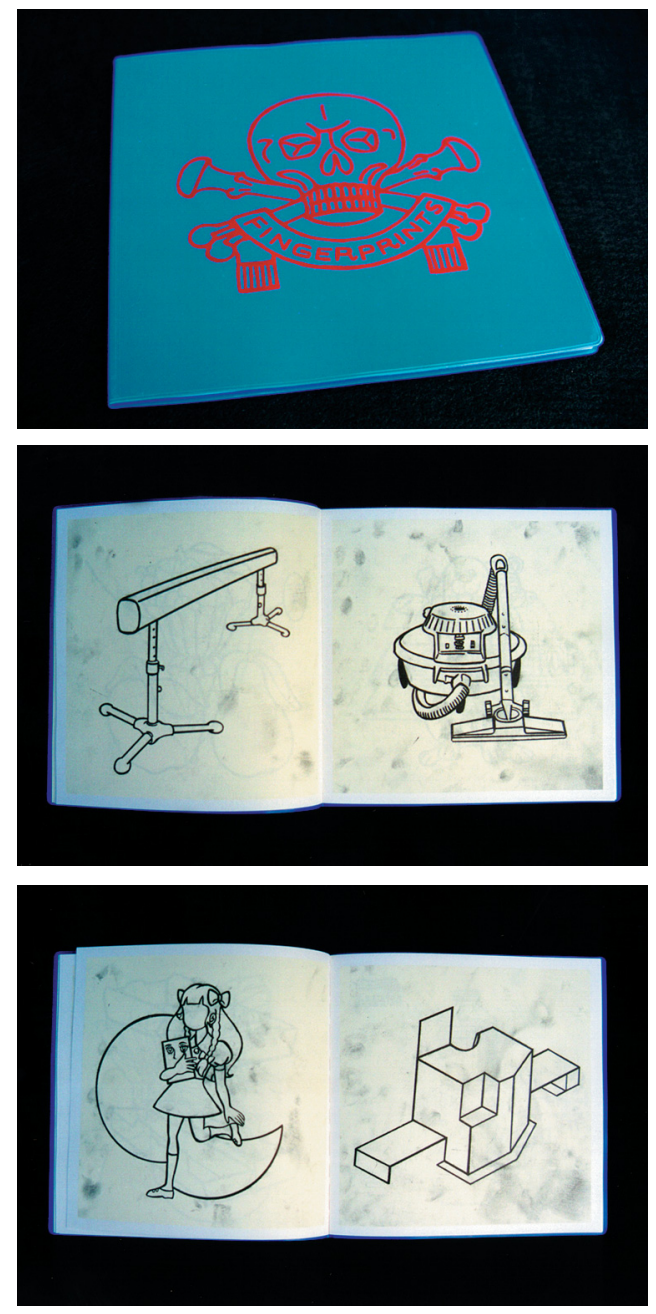

Hiro Sugiyama, Fingerprints, 1998.
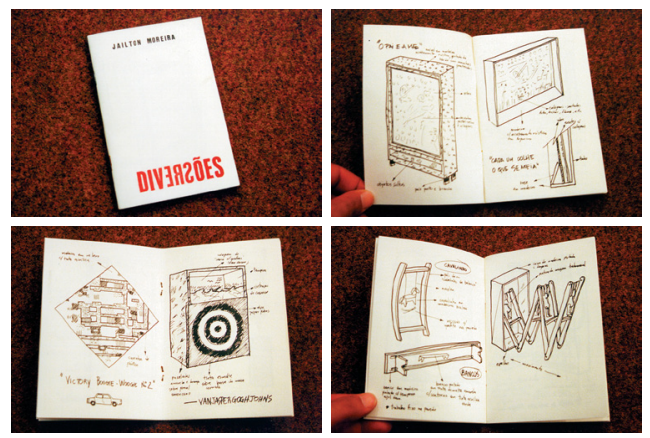

Jailton Moreira, Diversões, 1986. 
vencional sem conflitar com o propósito de seu conteúdo. De 1995 é A begginer's guide do art deconstruction, de Norman Conquest. É um livreto de vinte páginas de papel comum com impressão offset em preto e uma capa em papel um pouco mais espesso, pigmentado (impresso em serigrafia por Brian Clark). Essa é a terceira impressão; as outras foram em fotocópia, em 1991, e em periódico, em 1992. Ela não tem ilustrações, salvo uma vinheta na página de rosto (palheta e pincel) e uma foto no final (uma Mona Lisa com uma lata na cabeça). Conquest se apresenta como um artista verbo-visual, "membro fundador do grupo anticensura Beuyscouts of America", uma brincadeira com o nome de Joseph Beuys e boyscouts, "escoteiros". Ele propõe que sejam utilizados métodos eficientes para a desconstrução parcial da obra de arte ou para a sua obliteração total, de preferência
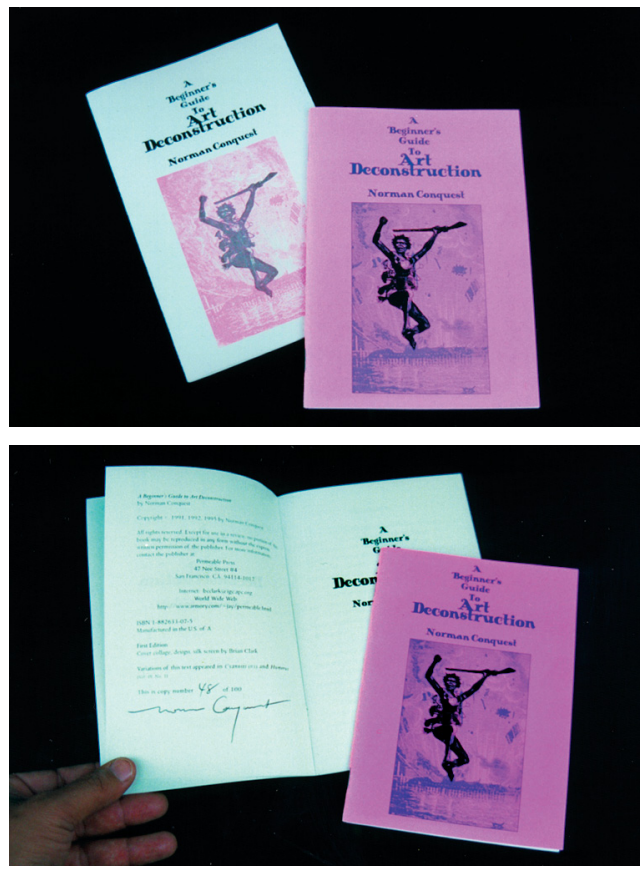

Norman Conquest, A begginer's guide do art deconstruction, 1995. a segunda, já que uma restauração manterá o seu valor, e, às vezes, esse valor poderá até ultrapassar o original. Recomenda quatro métodos básicos: demolição manual (introduzida pelos primitivos dadaístas; para obras complexas, como uma vídeo-instalação de Nam June Paik, recomenda ferramentas pneumáticas), queima (nesse caso deve ser levada em conta a legislação local a respeito da poluição por fumaça), desconstrução mecânica ("atacar e destruir uma obra de arte é ótimo, mas demolir uma galeria inteira ou museu é divino"; recomenda o uso de guindastes e escavadeiras) e explosão por dinamite (o método mais eficiente, que acompanha a rápida evolução internacional dos preços das obras de arte). Um anônimo teria declarado: "Eu nunca me esquecerei da noite em que eu arrebentei com seis Warhols com uma única carga". Impresso em offset com uma tiragem aberta, existe também uma edição especial de cem exemplares assinados, numerados e com uma folha encartada impressa em laser colorida. Por essa valorização, o preço sobe de dois para cinco dólares.

Um trabalho mais rústico, com a aparência de um polígrafo e todo em fotocópias em preto-e-branco com espiral plástica, é $A$ guide to art vandalism tools, their history and their use, 1996, "uma enciclopédia ilustrada" de Steve Goss. O texto é conduzido com seriedade e uma certa falsa cerimônia. Em ordem alfabética são descritas as ferramentas utilizadas por vândalos para destruir obras de arte. Por colagem (e talvez redesenho) são juntados ilustrações e diagramas descritivos de suas partes componentes ou de seu funcionamento. Além de útil para aspirantes ao vandalismo artístico, o livro 
de Goss oferece uma pesquisa histórica. Somos informados quanto ao uso de sprays, que o artista Tony Shafrazi, em 28 de fevereiro de 1974 entrou no MoMA e "grafitou" de vermelho a Guernica, de Picasso; para o público que olhava perplexo e para o guarda que o deteve ele declarou: "Chame o curador, eu sou um artista". Anos depois, em 1980, ele abriu uma galeria. O guia ainda descreve o uso de tesouras (que mereceram duas páginas), martelos, serrotes, canivetes, revólveres, fósforos, agulhas e até batom, entre outros objetos.

23 de novembro, 1977: Ruth van Herpen, em Oxford,Inglaterra, beijou uma pintura do artista de vanguarda norte-americano, Jo Baer - manchando-a de batom. Ela explicou ao juiz que a razão por seu vandalismo foi porque "[o trabalho] parecia tão frio. Eu só o beijei para alegrá-lo".

Acompanham o texto desenhos dos batons Coty, Elizabeth Arden, Yardley e lápis labial Gala.

O mimetismo com o objeto referido pode ser total, até atingir a qualidade de simulacro. Simultaneamente a isso, o discurso da obra será uma fala (ideia) inferida da formatação (imagem) do texto impresso. Esse texto passa então a ter função contextual. Esse é o caso de The menu, 1995, uma
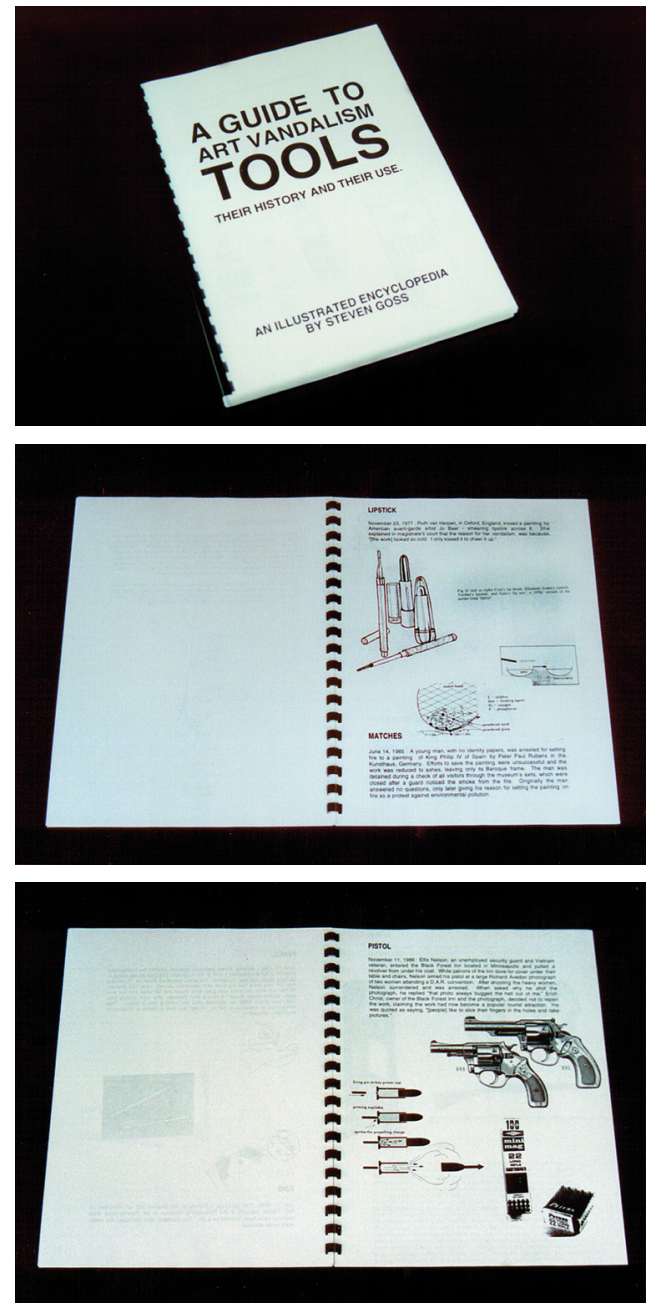

Steve Goss, A guide to art vandalism tools, their history and their use, 1996. estranha obra de Toby Lee Greenberg, com colaboração de produção de Sally Alatalo. A capa tem apenas o título, em dourado; é de um material sintético semi-rígido (possivelmente vinil), imitando couro ou napa, na cor bordô, com cantos arredondados. Tem 68 páginas unidas à capa por elástico dourado, com ponteiras em metal também dourado. O formato é $28,7 \times 22 \mathrm{~cm}$, maior que o usual para um livro, mas adequado a uma apresentação que imita um cardápio de luxo. Só existe impressão nas páginas ímpares, e apenas de texto. Os cardápios são em tipologia itálica script, fonte de texto frequente na emulação de requinte.

Não são dadas explicações. Na primeira página, centralizado, o prato: "lagosta ao termidor \& caviar". Na seguinte, "omelete de queijo / quiabo frito / bolo de chocolate" e a observação entre parênteses "(Vegetariano)". A próxima é mais elaborada: "coelho 
frito (de preferência selvagem) ao creme / caldo de carne com pimenta preta / biscoitos de leite desnatado com molho / torta de amoras com creme de nata batida". Os cardápios prosseguem, inclusive com pratos vulgares como Big Mac ou banana split. As pistas vão surgindo aos poucos. No pé das páginas, à direita, estão as informações do comensal, em tipos retos menores: "John Rook / 19 de setembro de 1986 / 2h11min / Raleigh, North Carolina". O prato, "12 cachorros-quentes". E a observação: "(Comeu apenas três)". Vai-se pressentindo a proximidade do esclarecimento. Descobrimos que "James Dupree Henry / 20 de setembro de 1984 / 7h9min / Starke, Florida" comeu pela primeira vez "uma dúzia de ostras com molho picante". O que se descreve é um quadro deprimente. São as últimas refeições de 34 condenados à morte no sistema prisional norte-americano. $\mathrm{O}$ trabalho tem uma atração ambígua, entre o kitsch e o político. A emoção estética pelo entendimento se transforma em dissabor, e daí para uma profunda dúvida a respeito da relação entre o objeto artístico e a mensagem explícita. O único gesto possível para esses condenados à execução é a autoridade para fazer seu último pedido, firmado na certeza de ser atendido. Além dessa versão, The menu tem também uma edição de luxo, com capa almofadada e cantoneiras de metal, mais uma litografia de um cardápio. Essa tiragem diferenciada possivelmente eleve o mórbido à dimensão do macabro.

Comer, morrer, amar são recorrências cada vez menos raras no livro de artista, acompanhando o crescimento da aceitação da narrativa nas artes visuais que utilizam as novas mídias, já não tão novas. A sexualidade, principalmente, reivindica para si um espaço mais significativo dentro da produção global.
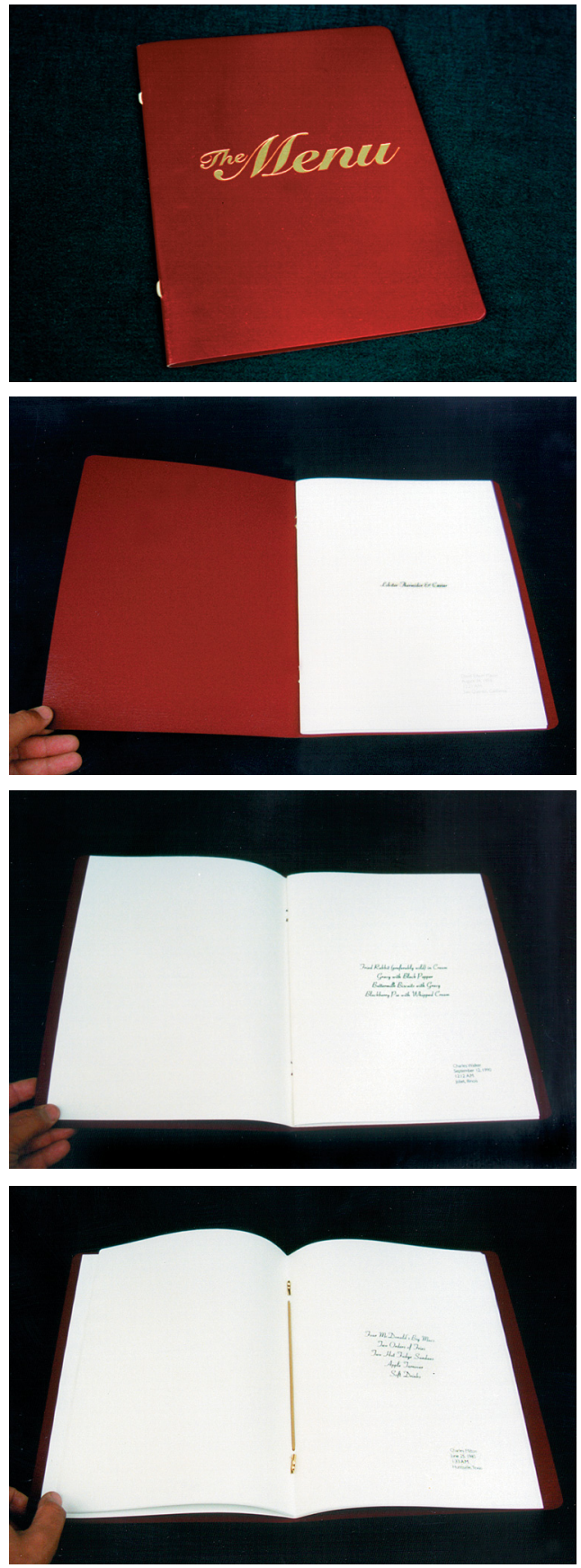

Toby Lee Greenberg, The menu, 1995. 
Mas curiosamente, a pornografia, que é a imagem, narrativa ou espetáculo que expõe um assunto ou motivo obsceno, parece ter uma ação muitíssimo diminuída no meio. O pornográfico talvez seja mais uma condição de consumo ou do consumidor de uma imagem, do que da própria imagem em si. E o livro pode ser, como citado anteriormente por Helen Douglas, um veículo que fecha, que esconde, em contradição com a sua função divulgadora. A propósito do elo de Jean Dubuffet com a palavra, primeiro com obras em colaboração e depois individuais, Riva Castleman aponta sua impossibilidade de ser pornográfico.

Nesse caso, Dubufett incorpora uma antiquíssima tradição de fazer livros "sujos". Imagens e textos pornográficos são muito mais velhos do que os próprios livros, mas a forma do livro tem sido sempre um contêiner perfeito para esconder tal material da visão geral. Porque a inspiração de Dubufett nesse período era a arte das crianças, suas atitudes não afetadas pelos códigos de conduta e representação foram tomadas indiscriminadamente. Diferente dos costumeiros encontros sexuais em bordéis, que encontram seu canal em livros com gravuras de Masson, Jules Pascin e Picasso, para citar os mais prolíficos nessa área entre os artistas do
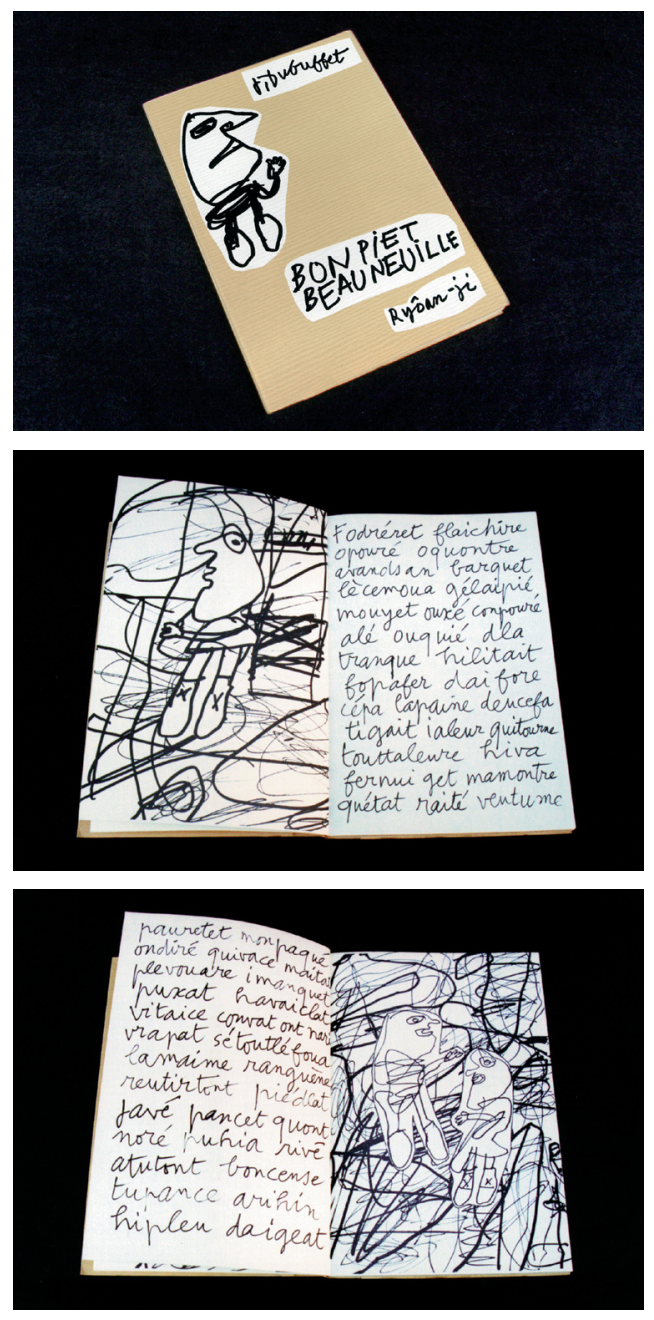

Jean Dubuffet,

Bonpiet beau neuille, 1985. século 20, os casais de Dubufett desafiam o contexto lascivo por serem simples, flutuantes, desenhos infantis de homens e mulheres fazendo sexo. (Castleman, 1994, p.46; imagem de Dubuffet, p.187) ${ }^{43}$

\footnotetext{
${ }^{43}$ Castleman se refere especialmente ao livro de Jean Dubuffet, Labonfam abeber par inbo nom, 1950, que não está aqui reproduzido por impedimentos de cronograma. O Department of Photographic Services and Permissions do MoMA gentilmente ofereceu a possibilidade de produzir uma foto para esta pesquisa. Como chegaria tarde, comprometendo muito os prazos, lamentavelmente foi necessário recusar. Utilizou-se, apenas, as imagens possíveis dentre as elegíveis. Acrescento que, por solicitação do Museu, as fotos das obras de seu acervo utilizadas devem ser acompanhadas, mesmo que em nota à parte, da legenda completa, como segue. Henri de Toulouse-Lautrec, capa frontal de Yvette Guilbert, com texto por Gustave Geffroy; Paris: L'Estampe Originale (André Marty), 1894; litografia por decalque impressa em preto oliva, capa com 38,2 x $41 \mathrm{~cm}$ irregulares; Coleção Louis E. Stern. Robert Rauschenberg, Shades; West Islip: Universal Limited Art Editions, 1964; múltiplo com seis litografias
} 
Castleman também observa que a representação simbólica tende a exceder em quantidade a representação gráfica. O livro de artista envolvido na arte conceitual estava inserido num período de abertura sexual e por isso tinha temas sexuais apenas ocasionalmente. Pornografia seria rara, e usada para declarações sobre a ordem social. Martha Wilson sugeriu algo semelhante (em entrevista para Thomas Padon, em Lauf e Phillpot, 1998, p.120) ao comentar que o erotismo, às vezes pornográfico, passa despercebido em suas ocorrências no livro de artista.

Dois lugares vulneráveis no mundo da arte onde os artistas têm sido escoriados são a arte da performance e a fotografia, ambos campos jovens. Livros circulam há mais de 500 anos, ao passo que a fotografia tem circulado somente há 150 anos, e a performance por 85 anos, mais ou menos. Nus em pinturas não erguem uma sobrancelha, mas corpos despidos podem todavia excitar a imaginação puritana. Além disso, você pode fechar um livro; ele não está na sua cara como uma fotografia de Andres Serrano.

A sexualidade está de fato mais presente através de manifestações confessionais, essas sim num número sensível, lado a lado com as confidências de problemas do afeto que envolvem o estado ou a condição de ser humano do nosso corpo. Isso parece ser amplificado pelas características inerentes à leitura. À parte o sentido estendido de leitura, que envolve percepção visual e associação de outras imagens que não a letra, ela é a decodificação de um significado compartilhado, que envolveria duas ações introspectivas: "ver a palavra e levá-la em consideração de acordo com informações conhecidas" (Manguel, 1997, p.50-51). A comunicação é compartilhada com maior eficácia pela visão unificadora, mas quando envolve a narração, essa é mais direta com o auxílio verbal. Cumplicidade e confidência próximas de seu rincão tradicional, a letra.

A relação entre emoção, comoção, corpo humano e arte encontra no livro um suporte com resultados especialmente expressivos. Como nos já citados Difficulty swallowing e The menu. Outro exemplo peculiar é a edição canadense bilingue m: melancholia E̋ melanomata/mélancolie et mélanome, 1996, de Barbara McGill Balfour. Fez parte de uma exposição homônima. Tem formato quadrado em papel cor de areia, com textos em tipologia cursiva criada pela própria artista e fotos em preto (impressão offset, com a participação de colaboradores técnicos). Somente uma foto é colorida. Algumas imagens reproduzidas pertencem às series litográficas Maculae, Melanomata e Taches de rousseur. O volume não é paginado, e tem os textos nas páginas ímpares e as imagens nas pares,

sobre plexiglas: uma permanentemente montada (página de título) e cinco intercambiáveis numa armação de alumínio com encaixes e iluminada por lâmpada intermitente; painéis com cerca de $35,5 \times 35,5 \mathrm{~cm}$ cada; caixa com 38,4 x 36,8 x 29,9 cm; doação de Celeste e Armand Bartos Foundation. Lucio Fontana, Portrait d'Antonin Artaud; Paris: Georges Girard (impressor do texto)/Le Soleil Noir, 1968; cinco múltiplos: um de aço polido, um de latão, dois de plexiglás colorido e caixa de madeira pintada; páginas: 19,5 x 14,2 cm; Monroe Wheeler Fund. Marcel Broodthaers, páginas não-numeradas de Un Coup de dés jamais n'abolira le hasard, de Stéphane Mallarmé; Antwerp: Galerie Wide White Space; Cologne: Galerie Michael Werner, 1969; fotolitografia em preto sobre papel transparente com páginas no formato 32,5 x $25 \mathrm{~cm}$; adquirido com fundos doados por Howard B. Johnson em honra de Riva Castleman. Todas as fotos foram produzidas em 2000 pelo MoMA. 
salvo em duas exceções. Autobiográfico, ele traz cruzamentos entre o estado mórbido que pode acompanhar a consciência de mortalidade, a depressão causada por um câncer de pele maligno (melanoma) e a etimologia de palavras como "melan", preto.

A linea alba existe, muitas vezes imperceptível, como uma linha pálida na superfície da pele da mulher, descendo do umbigo até a área púbica. Relacionada com níveis de ácido fólico, essa marca escurece pelo aumento da pigmentação durante a gravidez e se torna a linea negra. Essa linha normalmente desaparece após o parto.

Melanina é o pigmento escuro que dá cor aos cabelos e à pele. O elemento compositivo melan, do grego, significa negro, sombrio, escuro. O estado de depressão chamado de melancolia tem esse nome porque se acreditava que sua causa era a presença de bílis negra no corpo.

Eu aspirei ser inviolada, invulnerável. $\mathrm{Eu}$ poderia vestir roupas imortais como Ulisses, ou talvez um cilício. Um tecido prodígio. Mas mesmo Aquiles, mergulhado no rio Styx, tinha seu ponto fraco [spot].

A presença ameaçadora do preto é percebida diretamente pela capa e fotos, bem como por milhares de pequeníssimos pontinhos que recobrem o papel. Como cada sinal da pele da artista, que guarda em si um prenúncio de finitude.

Um outro tipo de comunicação verbo-visual é o que realiza uma dissertação "física" (num sentido ambíguo) apenas pela leitura de registros escritos, onde a imagem é apenas a imagem da caligrafia. Como em Figures of speech, 1995, de Joseph Grigely. Nesse caso a palavra é lida como parte integrante de uma imagem, as fotos de recados manuscritos. Por isso, dar forma à fala. Com formato um pouco maior que o
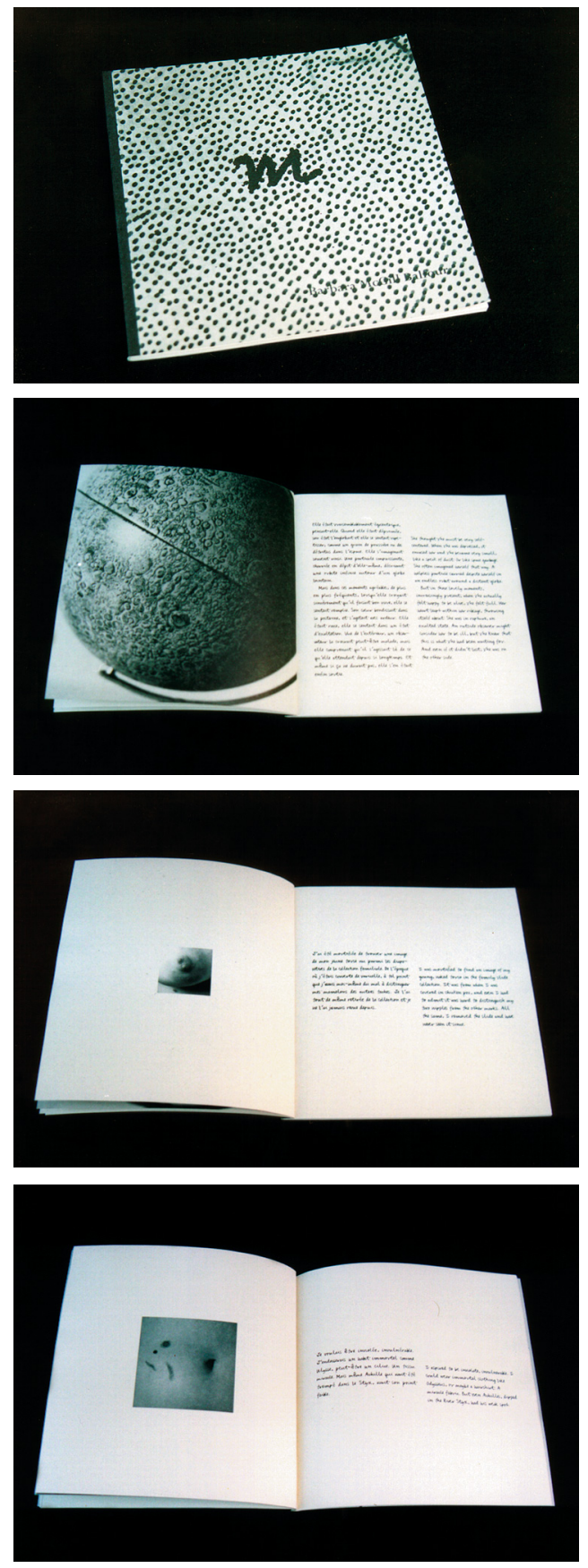

Barbara McGill Balfour, m: melancholia \& melanomatal mélancolie et mélanome, 1996. 
anterior $(26 \times 21 \mathrm{~cm})$, tem 32 páginas em preto-e-branco, com capa no mesmo papel, o que dá a ele aspecto modesto, sensação ampliada pelo uso, entre as reproduções fotográficas, de imagens fotocopiadas. Todas elas são de anotações ou bilhetes para o artista em pedaços de papel, versos de envelopes ou qualquer superfície que possa ser anotada. Há um cartão de visita com um coração desenhado, uma cartela de fósforos com "Eu sou Heidi. Itália.", há papéis apenas com nomes. Um bilhete pede que o artista busque uma torta grande, com peperoni em duas fatias. Um pedaço de papel pergunta se os preservativos precisam ser especiais e um outro se ele tem um poema de Gomringer. A fala é, portando, figurada, porque não existe outra possibilidade para o artista: ele é surdo. Tirados do contexto, esses pedaços de papel se tornam misteriosos, absurdos ou até engraçados. A leitura é exercitada pela imaginação, que deve reconstruir o contexto e a intenção de uma mensagem escrita às pressas. Como em uma indagação escrita no que parece ser um envelope: "Que tipo de arte você faz?".

\section{Polimorfismo, desconstrução e destruição}

Em artigo de 1993, Mirella Bentivoglio reivindicou a importância italiana na gênese do campo da arte em livro através da participação pioneira de Contemplazione, 1918, do escultor Arturo Martini, como um livro de artista estrito, e de Parole in libertà futuriste: tattili-termiche olfative, 1932, do ceramista Tullio d'Albisola (originalmente Mazzotti) e do poeta Filippo Tommaso Marinetti, como o primeiro livro-objeto. A obra de Martini é um pequeno livreto de 14,2 x 10,5 cm, concebido originalmente em
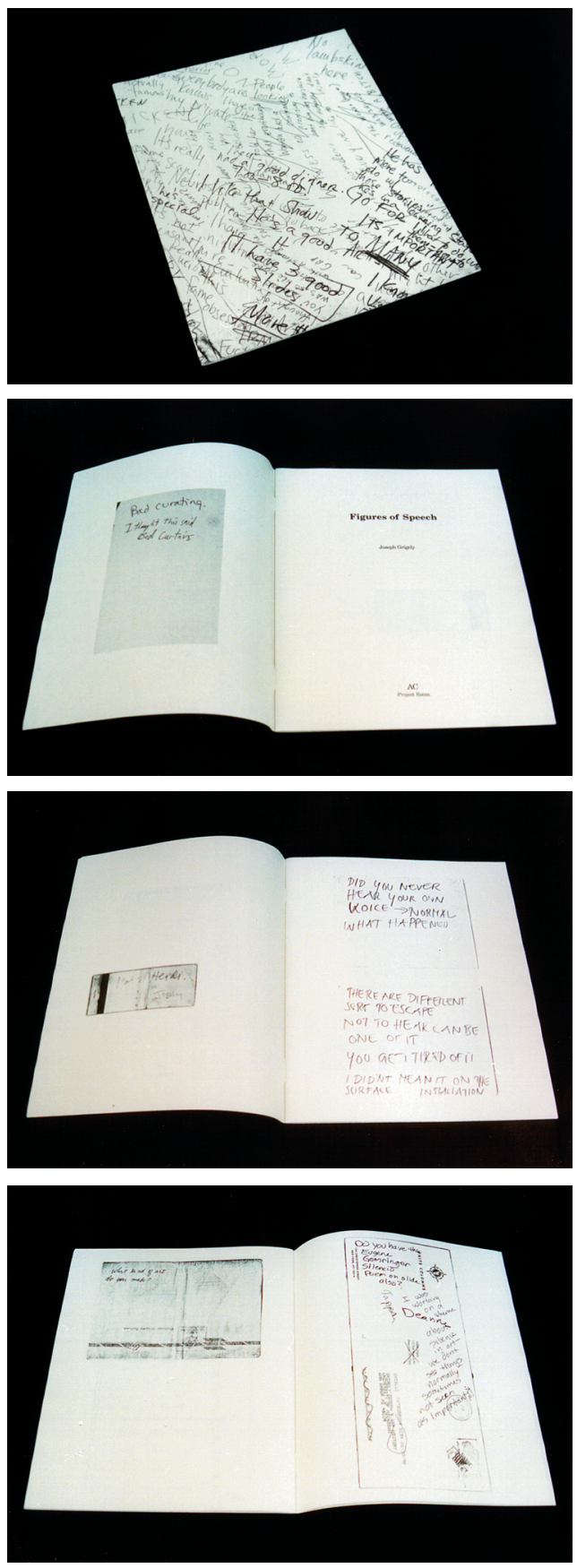

Joseph Grigely, Figures of speech, 1995. 
1916 e executado dois anos após pelo artista, numa primeira tiragem de poucos exemplares, e por ele reimpresso em 1936, sempre em xilogravura (40 gravuras, em 84 páginas). Teria sido o primeiro livro sequencial com escritos não semânticos: grupos de linhas ou faixas paralelas, com pausas irregulares e divisão em capítulos (Jentsch, 1992, p.182). O artista pretendeu-o uma prece, tendo como modelo um livro de rezas (Bentivoglio, 1993, p.93).

O livro de Tullio d'Albisola e Marinetti é maior $(23,5 \times 21,5 \mathrm{~cm})$ e mais pesado (600 gramas), feito com quinze lâminas de lata. ${ }^{44}$ Foi impresso em litografia colorida sobre folhas de lata, sendo o mais famoso exemplar do livro mecânico futurista. Foi elaborado na fábrica de objetos futuristas chamada Lito-Latta, criada em 1927.

Nenhum traço na sala de trabalho de prensas de impressão ou caixas de tipo, mas pedras litográficas para decorar superfícies de metal e um ensurdecedor barulho de tesouras, dobradeiras, aparelhos de fazer bordas. Embora prosaico, o jornalista se encontrava numa fábrica para a produção de objetos de folha metálica. Era aqui que as edições dos livros de lata dos futuristas eram manufaturados. A fábrica, empoleirada sobre os íngremes rochedos, projetando-se sobre o mar em Zinola, perto de Savona, empregava 180 pessoas, das quais 150 eram mulheres. Dado o caráter não-doméstico dos instrumentos pesados requeridos para processar o metal, essa alta percentagem de mulheres é surpreendente. $O$ trabalho era simultaneamente exaustivo e delicado. As páginas de cada livro eram viradas com a ajuda de juntas articuladas seguras por arames paralelos, ocultos na lombada tubular. (Bentivoglio, 1993, p.95)

Bentivoglio reitera que os livros-objetos "são livros que submeteram-se a transformações na forma, estrutura ou material". Esses três elementos de sua constituição passariam a ser mensagens. Poderia-se
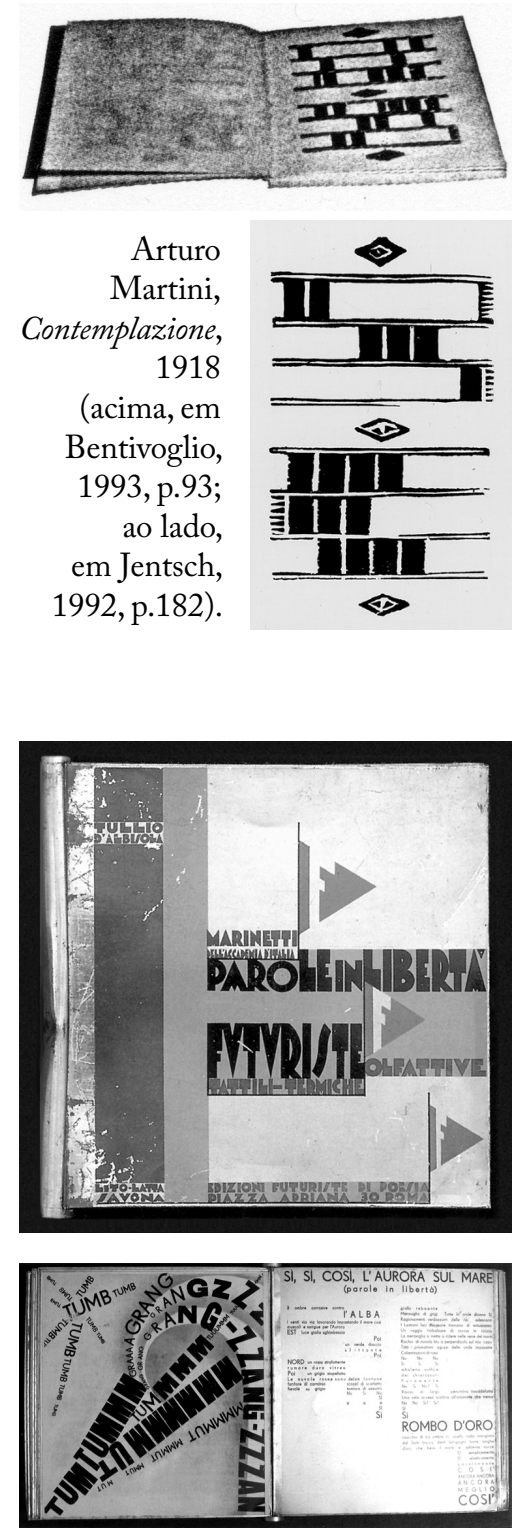

Tullio d'Albisola e Filippo Tommaso Marinetti, Parole in libertà futuriste: tattili-termiche olfative, 1932 (Jentsch, 1992, p.98).

\footnotetext{
${ }^{44}$ Aqui mais uma vez se apresenta a dificuldade de se precisar a página. Segundo Castleman (1994, p.223), 15 "fólios", incluindo a capa; segundo Jentsch (1992, p.98), 15 "folhas" de lata; segundo Bentivoglio (1993, p.95), 24 páginas; segundo Books as Art (1993, p.18), 26 "páginas". Provavelmente são 13 lâminas (26 páginas) mais 2 para as capas.
} 
dizer, por isso, que a diferença entre livros de artistas e livros-objetos é que "um livro de artista (como Contemplazioni) é um livro regular com um conteúdo irregular e o livro-objeto é um livro irregular" (p.95).

Independente das proposições sobre quem foi o primeiro a fazer o quê, a ideia do produto de uma fatura ou construção parece ser inseparável da arte bibliomórfica, mesmo quando conceitual. A cristalização do gesto ou ação que pesquisa pode ser considerada uma das significativas características de identidade do livro-objeto. Separar deste o livro de artista, exige algum cinismo científico, já que apenas os seus casos extremos podem ser isolados como típicos. Entretanto, é verdade que a liberdade formal possível é o principal objetivo experimental dos dois casos. Mas o livro objeto é mais plástico. Portanto, guarda mais as cicatrizes do gesto fundador.

Um caso raro de experimentação plástica é o que vem sendo desenvolvido por Neide Dias de Sá. É raro porque guarda uma rigorosa linha de pesquisa há muitos anos, comprometida com seus princípios geométricos. Isso não parece usual no livro-objeto, onde os artistas são camaleônicos, muitas vezes até a exasperação. Neide propõe uma conduta que invoca o método e a assepsia nos recortes da página, em obras praticamente inalteradas desde 1973. Essa linha diretriz, rigorosa, e num certo sentido classicista, esteve sempre ao lado da pesquisa intermidial. A busca da comunicação interpessoal pela visão foi sua premissa formadora. Fez-se presente na pesquisa da utilização de ferramentas artísticas na formação de crianças normais e excepcionais (dirigiu o Núcleo de Arte Heitor dos Prazeres, no Rio de Janeiro, de
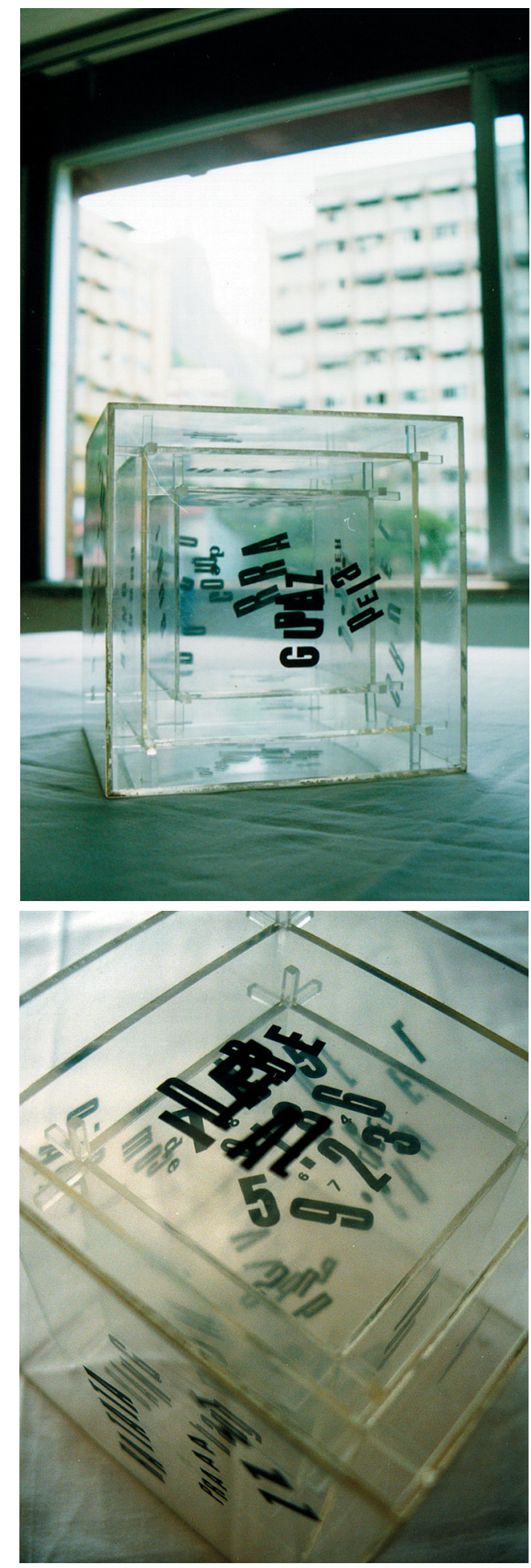

Neide Dias de Sá, Transparência (Caixa), 1969. 
1966 a 1983). Entretanto, foi com o grupo ou movimento Poema-Processo que ela buscou as soluções semióticas definidoras de seu projeto artístico, com pesquisas em códigos, composição visual, relação verbo-visual com ênfase na imagem, poemas espaciais, arte postal e eventos de rua, quase sempre relacionados com a poesia visual. Ainda aplicaria a noção de poema no cinema super-8, no vídeo e em out-door.

Em particular, dela deve ser lembrado, dos anos sessenta, as páginas sem palavras, com condensados raciocínios gráfico-ideogramáticos [...]; as leituras táteis, as contraformas de letras, as destruições matemáticas, o "strip" de 1967 onde as imagens fotográficas, tiradas de revistas ilustradas e objetualizadas por recortes, se dispõem em ordens diversas escolhidas pelo público. (Mirella Bentivoglio, 1980, apresentação para exposição em Savona, Itália $)^{45}$

Poema é a palavra-chave para a aproximação às obras de Neide. Por ser a coisa mesmo da poesia (do grego poíesis, "ação de fazer algo"), o poema (do grego poiema, "o que se faz") materializa a expressão, mesmo sem a presença de palavras. Suas incursões nesse campo serão, por isso, construtoras e processológicas. Produz poemas-objetos e livros-poemas, que era a forma como o poema-processo (e outros movimentos da poesia visual) denominava o livro-objeto por eles produzido. Seu cubo de acrílico incolor Transparência, de 1969, é por ela apresentado tanto como um poema-objeto como um livro-objeto. Tem outros dois cubos igualmente transparentes dentro dele, com palavras ou seguimentos de palavras em preto, aplicadas sobre as suas superfícies. Precisa ser manuseado para que as visões possam

${ }^{45}$ Tradução do italiano por Tânia Cervo.

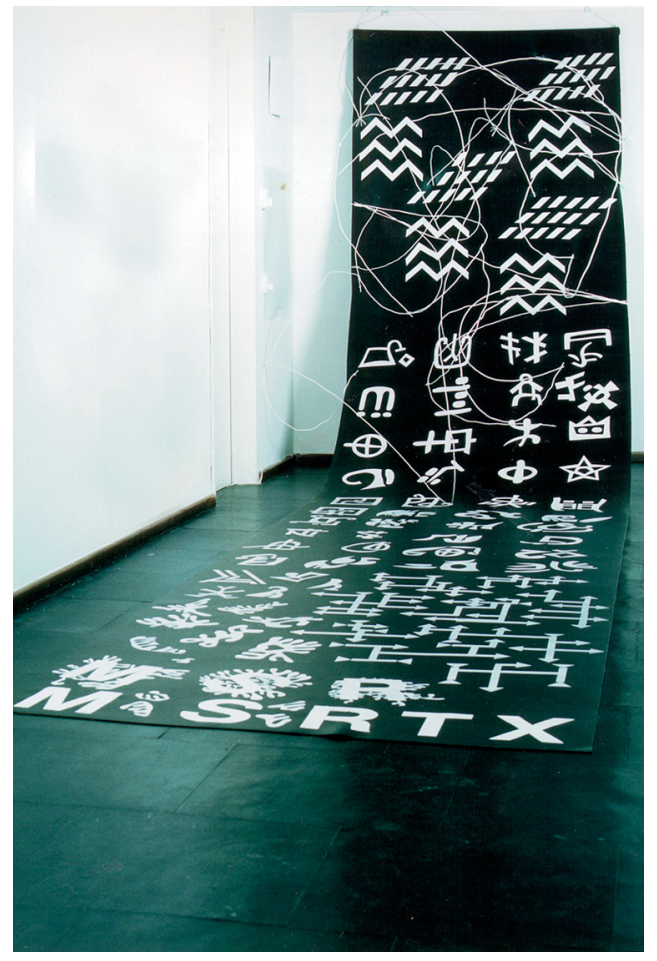

Neide Dia de Sá, Registros, 1998 (foto cedida pela artista).
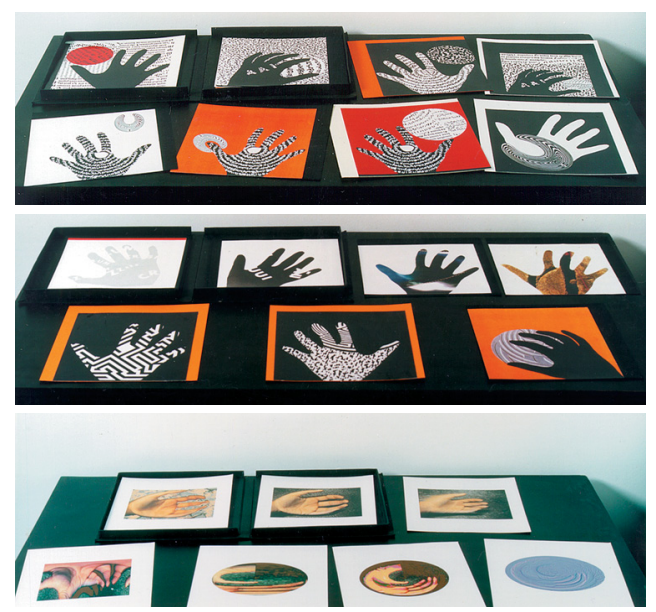

Neide Dias de Sá, séries Poemãos, 1976-1998 (fotos cedidas pela artista). 

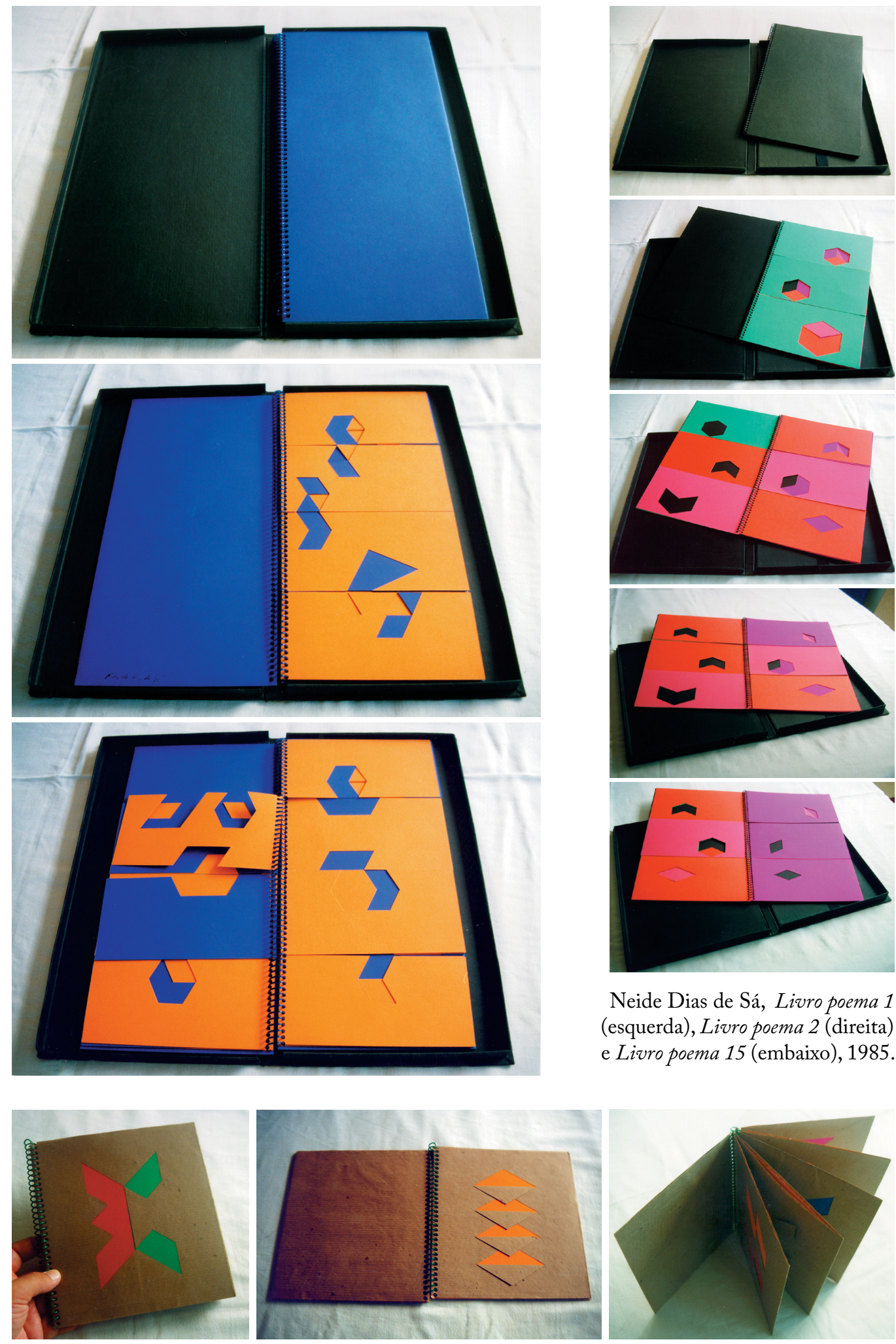
ser semantizadas a partir da sobreposição das superfícies. Apesar do título, a obra é conhecida simplesmente como $A$ caixa.

Registros, um trabalho recente de 1998,é de construção mais simples, embora maior. Trata-se de uma grande manta de borracha preta de $1,5 \mathrm{~m}$ de largura que pende da parede e segue pelo chão, totalizando 10 metros. Nela estão aplicados caracteres, ideogramas e outros sinais em vinil branco, além de gravetos também brancos. Pode-se, ou deve-se, andar sobre o trabalho. Alvaro de Sá propõe sua leitura acompanhada da experiência tátil com a borracha macia.

[...] Quase-escrita que pode ser lida a partir do "alto" ou do "baixo".

Partindo da parede lemos a síntese da evolução semiótica - os gravetos, memória do sinal, evoluindo lentamente até os meta-signos.

Começando pelo extremo do chão lemos o processo da poética contemporânea, que saiu do alfabeto, ou seja do discurso, para chegar ao poema visual: um "quadro" de signos à disposição do consumidor, onde gravetos convertem-se em código. Lemos também da história dos últimos tempos da arte contemporânea, que na pintura recuperou o uso dos alfabetos e na poesia o uso da imagem. (Alvaro de Sá, 1998, texto avulso)

A sequência Poemãos se aproxima dos livros mais frequentes da produção de Neide. Dentro de capas negras tipo caixa, lâminas soltas integram imagens de alfabetos, silhuetas de mãos e suas distorções. É uma obra em processo, iniciada em 1976 a partir de uma foto de 1970 que mostra a Caixa segura com os braços erguidos contra o sol. Cada versão foi executada com os meios disponíveis na época. O conjunto de 1978 foi executado com o auxílio
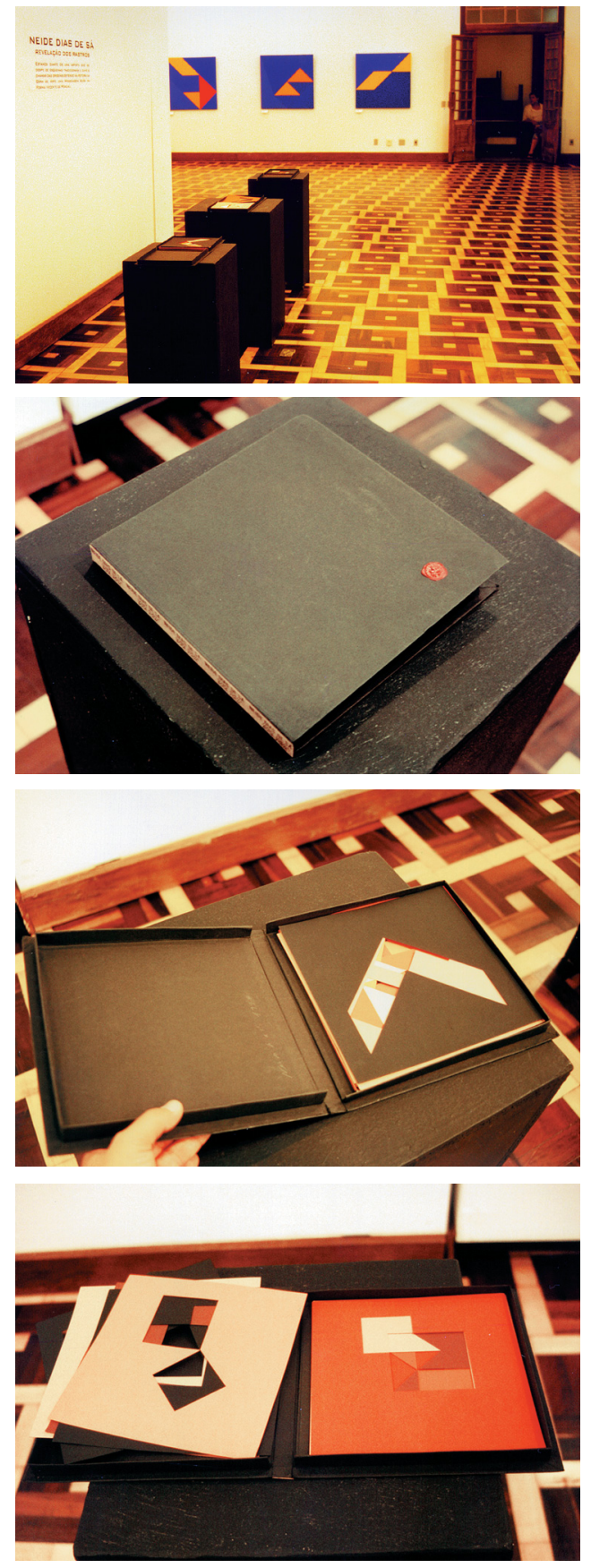

Neide Dias de Sá, exposição Revelação dos Rastros, Museu de Arte do Rio Grande do Sul, 1998. 
da fotografia. O de 1983 utilizou a fotocópia. O de 1995, a fotocópia colorida. E o de 1996, que ainda prossegue, incorpora a computação gráfica, existindo no papel e no computador.

O livro-objeto dominante na produção da artista tem uma forte unidade. Como já dito, sua conformação remonta a 1973. Eles não têm títulos individuais. Cada um é apenas um Livro poema. A feitura é quase um ritual: de folhas de papel colorido são recortadas formas geométricas, a partir de uma grade invisível de linhas ortogonais e diagonais. Não existem cortes curvos. São todos regulares e com elevado grau de acabamento. $\mathrm{O}$ trabalho é inteiramente manual, mas não permanece uma só marca de dedo. É liso, puro, preciso, de um abstracionismo geométrico de formas fechadas rigoroso. Não há espaço para acidentes. Em lugar disso, um extremo contraste entre a objetividade do gesto que corta com o estilete e a fragilidade passiva do papel.
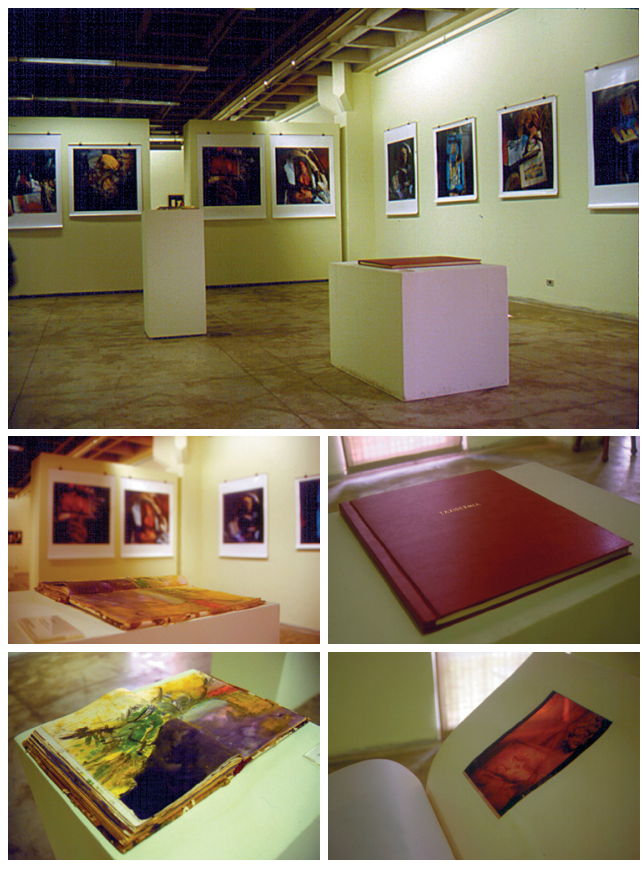

Gal Opiddo, série Taxidermias, na coletiva Anti-Mitos Urbanos, Museu de Arte Contemporânea da Universidade de São Paulo, 1996.

Executado o trabalho maior, o acabamento engloba a decisão de deixar as folhas soltas ou uni-las através de um espiral plástico, como os usados em cadernos. No primeiro caso, a artista propõe o jogo da visão através dos recortes, deixando ao fruidor a liberdade de alterar a ordem das páginas. No segundo, ela impõe o conceito ordenador da sequencialidade, narrando pelo corte uma experiência temporal. Nos dois casos, as páginas têm coloridos vivos, de duas ou mais cores por trabalho. Independente de serem folhas soltas ou em espiral (com capa), o grupo de páginas será acondicionado numa capa do tipo caixa, cartonada e revestida de papel preto. Em toda a extensão da lombada será colada uma tira de papel pardo na qual estão impressos "Livro poema" e a autoria.

Esses livros poderão ou não participar da pintura geométrica desenvolvida por Neide. Nesse caso, as páginas serão usadas como matrizes caleidoscópicas no exercício de procura de soluções geométricas e na integração de meios. Haverá, assim, na sala de exposição, um conjunto de pinturas recobrindo as paredes e, próximo a elas, à disposição do manuseio do público, um grupo de livros geradores. Eles, em geral, permanecerão no acervo da instituição curadora.

Deve-se lembrar que a integração do livro com outros procedimentos é mais frequente do que possa parecer, e com resultados enriquecedores. Veja-se como exemplo paralelo a esse, a mostra de fotografias de Gal Opiddo, incluída na coletiva Anti-Mitos 
Urbanos, no Museu de Arte Contemporânea da Universidade de São Paulo, em 1996. O formato é o mesmo, com ligeiras variações: as obras "principais" na parede (grandes fotos coloridas) e sobre dois pedestais, dois grandes livros encadernados. $\mathrm{O}$ primeiro tinha pinturas de objetos do cotidiano. Ele antes serviu para compor, junto com o objeto representado na página, naturezas-mortas com sugestão de antropologia urbana. Uma foto poderia mostrar uma cadeira quebrada, que tem sobre ela o livro aberto mostrando uma pintura da cadeira quebrada. Depois disso, o negativo ou fotograma da imagem, guardando sinais de deterioração, seria anexado a uma janela vazada numa página do segundo livro. No dizer da curadora Katia Canton (no folheto de divulgação), o fotógrafo constrói "kits de composição e conteúdo que, ao mesmo tempo em que comentam, atropelam tem-

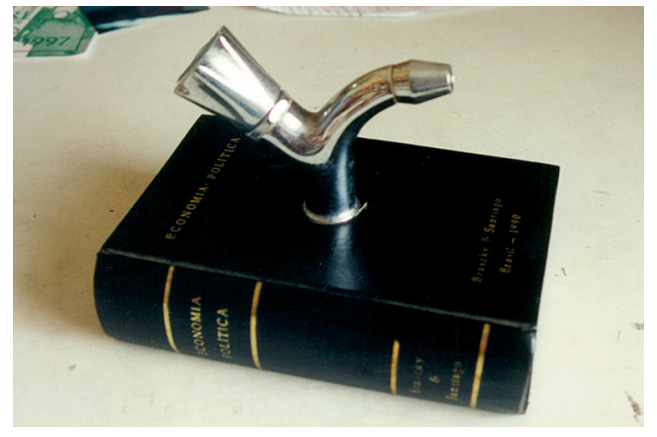

Paulo Bruscky e Daniel Santiago, Economia política, 1990.
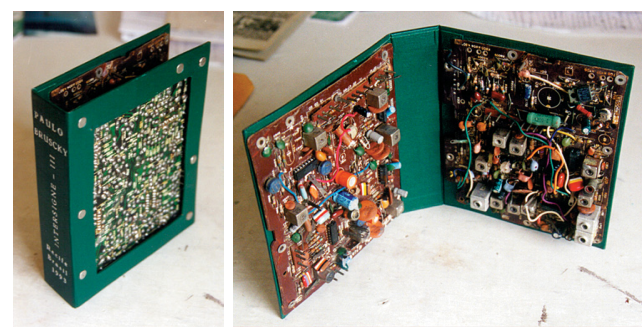

Paulo Bruscky, Intersigne III, 1993. poralmente esses percursos narrativos". $\mathrm{O}$ resultado é uma sensação estranha, como se vivêssemos uma integridade corrompida e reconstruída. O que vem de acordo com o título da série de Opiddo, Taxidermias. Existe um estigma de morte no processo. Se no seu trabalho persistem o excesso e a mobilidade contextual, gerando um clima de barroquismo apócrifo, em Neide a persistência da regra autoimposta insiste na manutenção de um certo sabor clássico. Nela, a quase imutabilidade de um grupo de seus livros-objetos justifica-se por seu papel de resultado de uma obra em progresso. Uma obra na qual o corte é criador e encerra, como numa cesariana bem-sucedida, o poder de trazer à visão a concreção da gênese.

O personagem mais frequente do livro-objeto multiforme é o artista experimental, provocativo, descontente com as soluções que encontra e, por isso, sempre na procura. Esse é mais ou menos o perfil de Paulo Bruscky, um dos mais inquietos experimentadores brasileiros de projetos intermidiais. Vem atuando em praticamente todos os espaços das vanguardas artísticas desde os anos 70. Chega a fazer constar em currículos seus "artista e inventor". Sua presença tem sido mais ativa na arte postal, no livro de artista e como instigador cultural. Começou a publicar livros de artista e criar livros-objetos em 1971, como parte de sua produção em parceria com Daniel Santiago. Seus trabalhos muitas vezes carregam doses de humor e ironia (como em Como ler, 1974, um livro pão em co-autoria com Santiago, edição da Padaria Nabuco, Recife). Participou de muitas exposições específicas. Na Holanda, teve acesso aos arquivos de Carrión. Em 1981, 

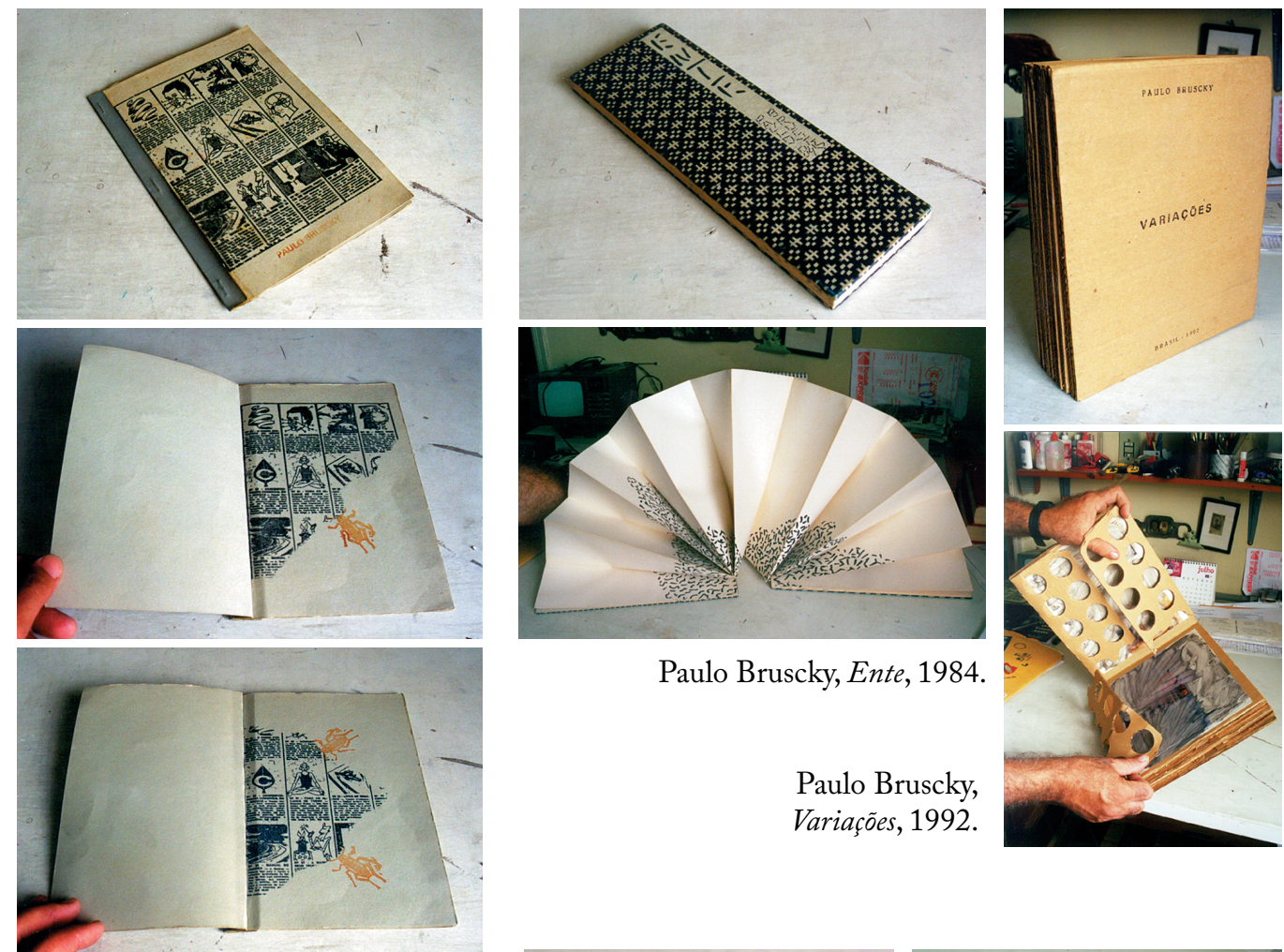

Paulo Bruscky, Ente, 1984.

Paulo Bruscky, Variações, 1992.
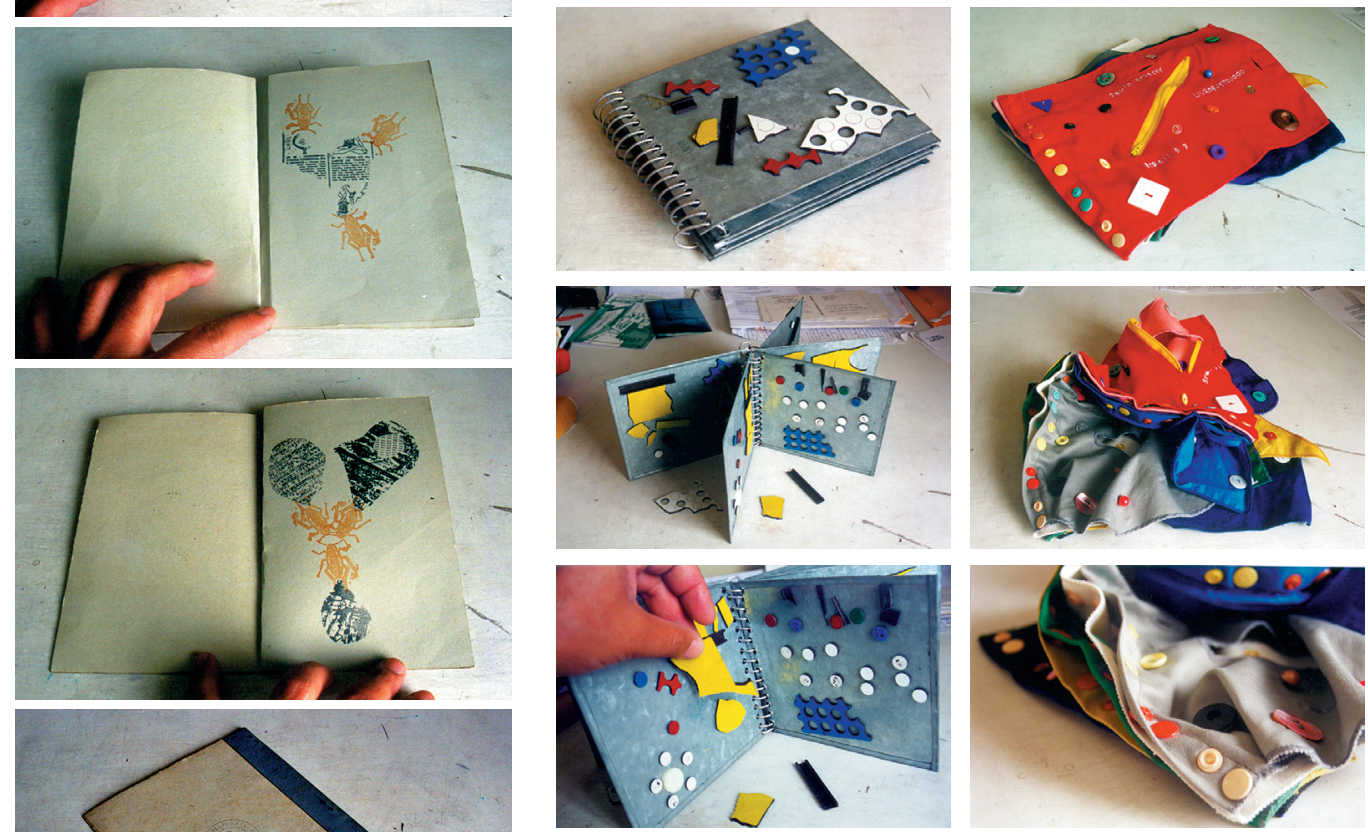

Paulo Bruscky, Livrobjetojogo 1, 1992.

Paulo Bruscky, Livrobjetojogo 2, 1993.

Paulo Bruscky, Rubber book, 1978. 
recebeu prêmio da Fundação Guggenheim, Nova York, por filme/livro, sendo bolsista da Fundação no ano seguinte.

Bruscky opera no terreno da absoluta criatividade. Difícil de ser enquadrado, pode-se defini-lo ao menos como anticomercial e marginal. Produziu livros-objetos de todas as formas possíveis. Fez livros em xerox (Alto retrato, 1981, já comentado em capítulo anterior), com carimbos (Rubber book, 1978, onde baratas comem e "descomem" o texto), de papelão (Variações, 1992, com intervenções a tinta sobre papelão ondulado), de lata (Livrobjetojogo 1, 1992, com sobras de ímãs coloridos), de pano (Livrobjetojogo 2, 1993, muito colorido, com casas e botões), livros que abrem em sanfona (Ente, 1984), livros que nunca abrem (Time of book, 1994, de latão amassado), livros alterados (Volume superior/volume inferior, 1990, com Daniel Santiago, um livro serrado em dois), além de muitas intervenções metafóricas em assemblagem (Economia politica, 1990, com Santiago, com uma torneira metálica incrustada na capa). Sua produção é muito

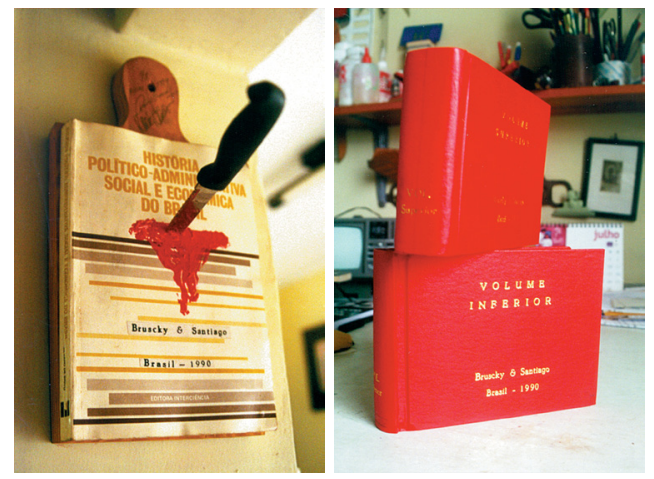

Paulo Bruscky e Daniel Santiago, História politico-administrativa do Brasil e Volume superior - volume inferior, 1990.

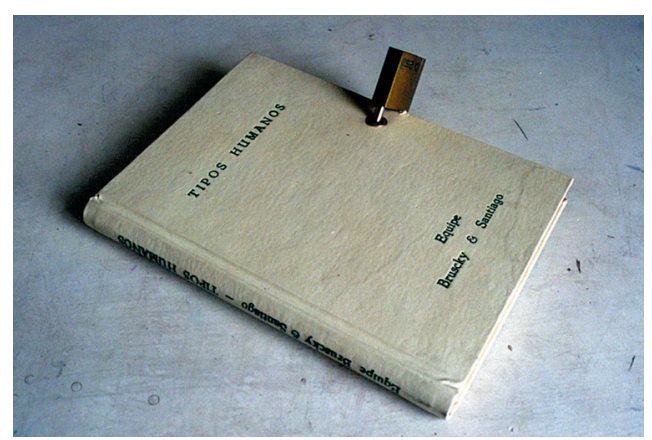

Paulo Bruscky e Daniel Santiago, Tipos humanos (1990?). extensa. Numa única individual, em 1984, ele expôs 75 livros-objetos. Até 1998 já tinha realizado cerca de 250 livros.

Não existe linha dominante na produção de Paulo Bruscky que não seja a sua própria exuberância criativa. Ele é o anticlássico por excelência.É gauche. "Bruscky iconoclastou Pernambuco todo." ${ }^{46} \mathrm{O}$ que não significa que seja um biblioclasta. Ao contrário, em sua obra ele reafirma o códice como seu arquétipo. E os ferimentos, muitos e diversos, ou são compositivos e necessários à obra, ou são comentários aos problemas sociais, políticos ou culturais, os quais por vezes o livro representa. Por essa produção abundante, em cascata, Bruscky é exemplo cabal do que Mirella Bentivoglio chama de "librismo".

A onda definitiva que percorreu o mundo da arte pelo livro de maneira tão marcante, parece fazer parte de uma maré maior, movimentada a partir de projetos de artistas

\footnotetext{
${ }^{46} \mathrm{Em}$ texto de José Roberto Aguilar sobre a homenagem de Paulo Bruscky ao poeta Torquato Neto, no catálogo Iconoclastias culturais, São Paulo: Casa das Rosas, 1998, página 8.
} 
solitários ou em parceria com escritores de fins do século 19. Esse processo foi reconhecido por Bentivoglio (1990) como uma tendência para escolher o livro como espaço de todo tipo de manifestação. Ela chamou essa tendência de librismo, em italiano, ou bookism, em inglês. $\mathrm{O}$ librismo (nossa origem latina permite a manutenção do termo) considera o livro como um objeto que tem sua forma e conteúdo como entidades inseparáveis. A definição é simples e Bentivoglio não se detém em prestar exagerada reverência ao livro de artista conceitual, bem como não tem preocupação de ressentimento com galicismos ou anglicismos, excludentes e, portanto, diminuidores do universo em questão.

Assim, no livro, abrem-se todas as cachoeiras da expressão e há quem o transforma em matérias nobres ou pobres ou em formas de mãos e de rostos e quem o faz vegetar ou crescer à medida do homem ou o identifica no mistério da circularidade cósmica fechando-o em dois dorsos; ou o "libra" no ciclo ou o metaforiza como respiro, ou o esconde em uma caixa de fósforos; há quem o penetre ou o finge, o lacera ou o imobiliza, o petrifica, o queima, o costura. Mas as operações de denúncia da história, uma

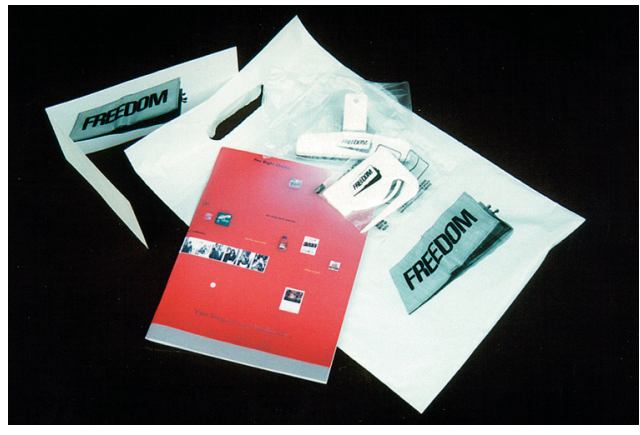

Group Material (Doug Ashford, Julie Ault, Thomas Eggerer e Jochen Klein), Market, 1995.

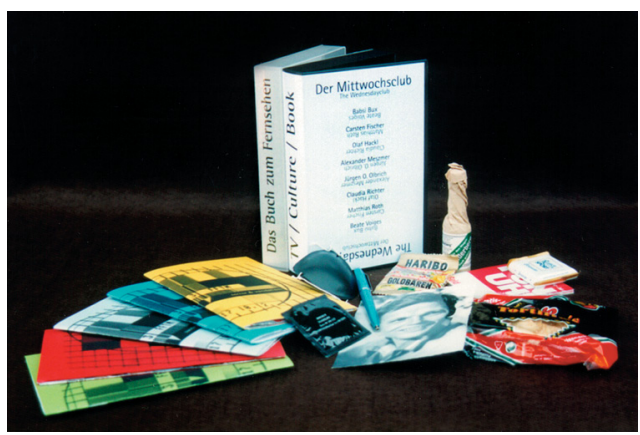

Der Mittwochsclub/ The Wednesdayclub (Babsi Bux, Carsten Fischer, Olaf Hackel, Alexander Meszmer, Jürgen O. Olbrich, Claudia Richter, Matthias Roth e Beate Voiges),

Das Buch zum Fernsehen - TV/Culture/Book, 1997. história que este objeto testemunhal tem, ele mesmo, determinado e transmitido, são somente ações de despegamento, de resgate do sacro sinal do conhecimento no redemoinho "orgiário" da matéria. (Bentivoglio, 1990, p.10) 47 $^{47}$

Essa demonstração de carinho pelo livro é compartilhada por Judith Hoffberg, que manifestou esse sentimento em muitas ocasiões. Sobre livros feitos como peça única, que podem rapidamente entrar no circuito de exposições ou serem comercializados, sem a necessidade de impressores industriais, Hoffberg nota que muitas vezes são tratados como ícones ou mesmo talismãs. Sua execução escultórica constituiria um "trabalho de amor" (Hoffberg, 1993, p.12 e 13). Sobre os livros de artista em geral, ela destaca o grau de ternura envolvida em sua feitura e seu desfrute.

\footnotetext{
${ }^{47}$ Tradução de Tânia Cervo.
} 
Masterbox, 1998 (amarela), Masterbox II, 1999 (branca), e Masterbox \#3, 2000 (verde, aberta).

Editadas em Buenos Aires no formato $12,1 \times 8,3 \times 2 \mathrm{~cm}$.

Participantes (e suas caixas): Alejandro Ros (3), Ana Shprejer (2), Andrea Shwartzman (2), Bill Fick (3), Carla Bertone (2), Carla Lucarella (1), Carolina Mikalef (3), Cecilia Pavón (3), Cecilia Szalkowicz (1, 2, 3), Cristian Turdera (3),

Cristina Reche (2), Daniel Joglar (3),

Diego Bianchi (2, 3), Diego Posadas (1), Eduardo Arauz (2), El Niño Rodríguez (1), Elenio Pico (1, 2, 3), Eleonora Margiotta (3), Fabián Muggeri (2), Fabio Zimbres (1, 3), Fernanda Laguna (3), Fernando Brizuela (2), Florencia Cacciabúe (2), Florencia Puzzo (1), Gabriela Forcadell (1, 2, 3), Gastón Pérsico (1, 2, 3),

Guillermo Ueno (3), Gustavo Navas (2), Helio Fervenza (3), Hernán Salamanco (1, 3), Jaime Serra (2), Javier Galarza (3), Juan Tessi (3), Juana Ghersa (1), Julia Masvernat (1), Julieta Escardó (1), Karin Idelson (1), Laura Escobar (2), Leo Vaca (2), Lola Goldstein (2, 3), Lucia Koch (3), Luciana Lardiés (2, 3), Luis Lindner (1), Magdalena Jitrik (1), Marcelo Sapoznik (1), María Delia Lozupone (1), María Guerrieri (3), Maria Ivone dos Santos (3), Mariana Grekoff (3), Marta Almeida (1), Matilde Oliveros (1), Maureen Hallbol (1), Max Gómez (3), Mayumi Nakamura (2), Nacho Iasparra (3),

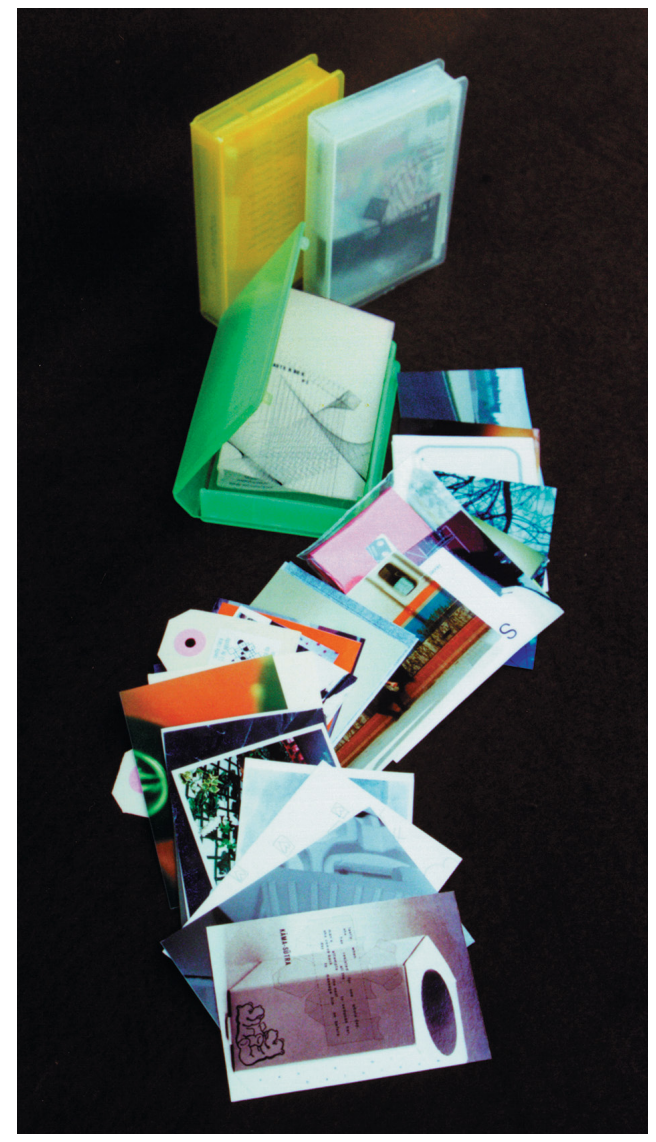

Pablo Ruiz (1, 2), Pablo Zicarello (2), Rapa Carballo (1), René Parrondo (3), Roberto Conlazo (1), Sandra González (1), Silvia Troian (3), Tea Alberti (1), Verónica Romano (2,3), Wilip (1, 2,3), Xcella/Chávez (1) e Yanina Szalkowicz (3).

Livros-obras, livros de artistas, livros feitos por artistas, livros-objetos - uma terminologia que não tem sido assentada por aqueles desta área, mas que agora tem ingressado na literatura como livros de artistas - estão ainda a se autodefinir, não para o iniciado, mas para o não-iniciado. Esses trabalhos de arte requerem cuidado terno e amoroso, uma generosa abundância de técnicas de preservação casada com uma compreensão de sua fragilidade e intimidade. [...] Essa ideia de acondicionamento para ideias visuais e verbais está ainda tentando encontrar uma definição, um lar, um lugar para ser reconhecida à vontade, prontamente e facilmente. [...] Nesta época de microchips e microcomputadores, o livro-obra é um bem-vindo antídoto tátil, visual e verbal aos pixels e ao discurso eletrônico em nossas vidas. (Hoffberg, 1993, p.15)

E de novo caímos no problema interminável dos conceitos. A área de sobreposição entre o livro-objeto e o livro de artista estrito parece ser muito maior do que se afirma, 
por um motivo prosaico: são originalmente frutos da arte, portanto reivindicam alguma liberdade de forma e linguagem. Dessa liberdade seriam gestadas as obras que provocariam as críticas mais fortes.

Clive Phillpot (1993, p.10) considerou que houve "o sequestro da forma do livro para a disseminação de arte primeira para uma grande audiência", especialmente nos anos 70, com uma "erosão de ganhos" nos anos 80, num mercado que queria "novos tipos de preciosas edições limitadas e antiliteratos livros únicos”. Essa erosão de ganhos estaria diretamente ligada à pressão do mercado para um expressionismo pictórico "aquecido no microondas". A ênfase seria ainda mais ampliada para os livros únicos feitos à mão e os livros-objetos. O conceito "livro de artista" se estenderia até as edições de luxo. Se a quantidade estava ampliada, "enquanto muitos ofereciam inspiração, instrução ou deleite, existiam muitos mais que evidenciavam ideias pobres executadas pobremente", vítimas da "superindulgência do culto dos materiais e excentricidade da forma". Ainda segundo Phillpot, o ideal de democratização da arte e a crença implícita de aptidão literária seriam colocados de lado "pelo culto do livro-objeto antiliterato, que não pode ser aberto e fetichista. $\mathrm{O}$ trabalho de centenas de artistas sem talento se tornou horrendamente visível." Considerou parte significativa da produção do início dos anos 90 como de livros-objetos mudos, ostentativos e lúgubres, lado a lado com obras luxuosas e artesanais, mas com algumas tentativas sérias de se continuar a produzir os múltiplos e livretos baratos.

Em texto de 1998, Phillpot retoma o problema, que parece maior para ele do que é para os artistas. Observa que muitos são seduzidos pelas "estruturas excêntricas", o que os levaria a desconsiderar o potencial do códice.

Os resultados são altamente visíveis. Exposições são atravancadas com bizarras, desfuncionais livro-construções; páginas se desconjuntam em todas as direções; e afetados, mudos livros-objetos, que só servem para fetichizar a cultura livresca, envaidecem-se sob o vidro. Para os mal-informados esses são livros-obras. Entretanto poucos livros de artista múltiplos empregaram variações da forma do códice para atender fins específicos. (Lauf e Phillpot, 1998, p.54)

Seria esse o antilivro citado por Plaza (1982, não paginado) como perversão sobre o livro? Talvez tanto o livro de artista como um objeto, como o livro de artista como uma ideia, se desconstruam por uma possível ansiedade de se afirmar mais como objeto de arte do que de comunicação. Como um tipo brando de egoísmo. Além disso, eles têm seu jogo de tensões (mais ou menos de vanguarda) em oposição dialética ao seu aspecto imóvel (oferecimento ao espetáculo) e a sua participação como obra da vida profissional do artista. Opiniões que percebiam isso já estavam registradas em Art-Rite, número 14, de fins de 1976. Como a de Ted Castle (p.7).

A coisa terrível sobre o conceito dos livros de artistas é que ele contém todos os defeitos dos conceitos de arte, artista e livro. [...] Esse desenvolvimento provavelmente ainda está na sua infância. [...] Mesmo estando à espreita por novas formas e na espreita contra a banalidade, os artistas se aproximam do livro cuidadosamente, como um gato se aproximando de um presente de Natal [...]. Muitos artistas têm horror à literatura, para a qual o conceito livro é altamente 
devedor. Não sempre, mas frequentemente, artistas são pessoas que tanto têm sido intimidadas por livros, como que os têm desdenhado. Desse modo, muitos dos livros são tão diferentes de livros quanto possível. Esse efeito é estreitamente ligado às mitologias da linguagem.

A declaração de Richard Nonas envolveu a escultura de forma direta como alternativa para uma dificuldade de escrever (p.11).

E eu fiz escultura. E aquilo era melhor; mais geral, mais difuso, mais ambíguo - mas também mais imediato. [...] De novo algo estava perdido. Algo importante para mim: uma qualidade narrativa que me mexe e me excita. Algo que eu não posso obter e não quer entrar na minha escultura. É uma qualidade temporal; lembranças específicas usadas como blocos de construção numa escultura que serpenteia pelo tempo. Portanto eu faço livros também. Mas diferentemente do que eu fazia antes. Meus livros são como esculturas agora; construídos pelas mesmas razões e do mesmo modo. Eles visam os mesmos sentimentos ambíguos, trabalham com as mesmas formas não tão regulares e os mesmos materiais pré-formados eles são objetos; objetos para se lidar. Mas eles fazem o que minhas esculturas não podem: eles saltam, eles movem, eles serpenteiam com a riqueza da ocorrência verdadeira - eles são o espaço entre as esculturas.

Pode-se dizer que essas afirmações, feitas na etapa "adulto jovem" do livro de artista, e situadas entre outras de ação conceitual, sugeriam (mesmo que essa não fosse a sua intenção) uma retomada de soluções mais espaciais e lúdicas. Como ponto positivo, isso desobrigava o artista da dependência verbal, em favor de mais estimulantes projetos visuais. $\mathrm{O}$ ponto negativo, se tanto, foi o transbordamento de uma produção espalhafatosa, frequentemente vista com insatisfação por alguns críticos e historiadores.

Anne Moeglin-Delcroix confirma a oposição entre os criadores de livros de artistas estritos e a maioria dos criadores de livros-objetos, concordando com o ponto de vista de Gilbert Lascault segundo o qual eles corromperiam o livro de todas as maneiras, gerando obras "depravadas" (Moeglin-Delcroix, 1997, p.306). Haveria, assim, uma violência biblioclasta a causar dano à potencialidade legível do livro, como na obra de Gérard Duchêne, nos anos 60 ligado ao grupo Textruction, algo como "textruição", que fazia "livros para destruir o livro". Além disso, existiria uma "bibliopraxia", manifestada pelo empréstimo de soluções editoriais clássicas, ou pela ação ou intervenção sobre obras já publicadas, o que estabeleceria um vínculo estreito "entre convenção e experimentação, tradição e invenção, respeito e liberdade".

Os trabalhos menos convencionais quanto ao abandono da página têm um débito inegável com Marcel Duchamp, em especial com a concepção de volume que guarda volume, como contêiner de informação tridimensional, com ou sem o acompanhamento da palavra, preservando ou negligenciando a página. Esse procedimento encontrou um multi-

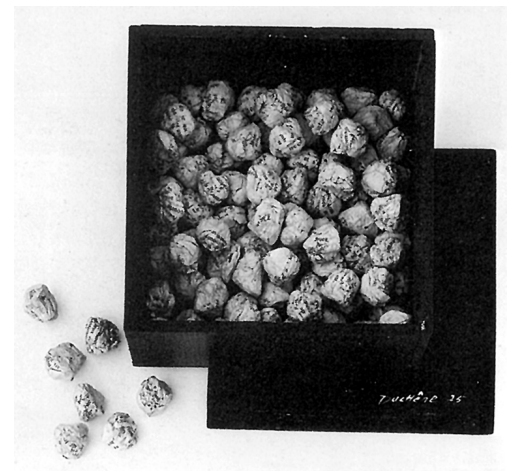

Gérard Duchêne, Livre-boules, s.d. (Moeglin-Delcroix, 1985, p.118). 
plicador muito pessoal na figura de Joseph Cornell, com suas caixas e colagens. Renée Riese Hubert avalia que elas podem ser consideradas colagens tridimensionais ou livros subvertidos. Permaneceriam nelas o elo com as artes visuais e a derivação literária. Daí a derivação do livro, agora em sentido levemente diverso do antes citado Ted Castle, como a própria literatura tem uma parcela de sua evolução em dependência das convenções ou limitações do suporte. São construções-livro manufaturadas, relacionadas com o objeto surrealista. São objetos modificados, perturbados ou interpretados "em que o ponto de partida coincide com um objeto específico: um livro. Como a ênfase cai na fabricação do objeto, não no texto, Cornell, que poderia ter parecido marginal ao nosso propósito, é visto como um precursor da recente experimentação na arte do livro" (Hubert, 1988, p.340).

Comentando os resultados obtidos por ele ao inserir objetos em buracos quadrados no centro das páginas de alguns trabalhos, Hubert nota o diálogo entre as duas e três dimensões.

A destruição da integridade do livro e da unidade da página resulta num volume, nos dois sentidos da palavra. Não é um texto específico mas a própria textualidade que é ilustrada, porque a página vira um fragmento de um volume feito visível a partir do interior ao invés do exterior. Ao mesmo tempo, por meio de seus usuais peepshows, Cornell nos distrai do ato de leitura. (p.341)

Hubert ainda destaca os trabalhos de Jan Kristofori e Helmut Löhr. Do primeiro ela destaca a total cobertura com linhas impressas.

Escrita, impressão em todo o lugar e nenhuma linha para ler! A imagem da impressão substitui o texto; a visibilidade faz a legibilidade fútil. Ou ainda, texto e imagem se problematizando um ao outro, assim como simultaneamente atraem e repulsam o leitor.

Aos livros de Löhr, Hubert considera "desviados".

O livre-objet de Löhr sugere uma peça de escultura acabada não em latão ou mármore, mas em papel. Páginas são curvadas, torcidas, forçadas a se sobrepor; e Löhr comenta sobre nossa cultura colocando a leitura, feita para sempre inacessível, num pedestal. Também parece que a ilustração tem finalmente devorado e absorvido seu outro, o texto. A tensão entre palavra e imagem, sempre latente nos trabalhos surrealistas levantados, tem-nos impulsionado além do livro ilustrado. (p.342)

O assunto da pesquisa de Löhr é o próprio estado do livro como obra da arte e da cultura. A mensagem, no sentido de informação objetiva, deixa de existir, em favor de uma visualidade crítica e contemplativa. Ele primeiro interfere na existência ou funcionalidade inerente ao livro, como etapa anterior ou paralela da extinção da condição de ser livro. Para Wolfgang Wangler, "a destruição da mensagem original não é a destruição da mensagem pura e simples". Entende que o ato de rasgar ou arrancar páginas, cortá-las, serrar os volumes, queimá-los, picá-los ou toda a sorte de injúrias aplicadas, provocam a "alienação do livro" pela nova qualidade modelada de "livro-escultura". Wangler ilustra esse processo através de uma intervenção executada em sua galeria.

Ele arrancou alguns tijolos da alvenaria e os substituiu por pedaços de livros publicados no meu estabelecimento. Aqueles livros foram, claro, destruídos e tomado a forma de tijolos. 
Os conteúdos desses livros presos na parede parecem estar perdidos. Os livros se tornaram objetos e somente podem ser contemplados visualmente, afinal de contas um paradoxo para com o sentido original de transmissão de mensagens. Os volumes alienados se tornaram parte da obra de alvenaria [...] isto é, na formação de corpos arquitetônicos. (Helmut..., 1985, p.3)

Pode-se aqui propor a mesma observação do poeta da "escrita destrutiva" e da contracultura, preso mais de uma vez por obscenidade, d. a. levy (ele queria que seu nome fosse escrito com minúsculas): "O que pode ser mais obsceno do que a recusa em comunicar?" (JAB 10, 1998, p.18)

A propensão à exacerbação do corpo do livro, além de facilmente encontrável em propostas isoladas, pode ser identificada de modo ainda mais didático em exposições coletivas. Para The Altered Page, ocorrida no Center for Book Arts, em Nova York, em fevereiro e março de 1988, Marvin Sackner selecionou de seu arquivo obras verbo-visuais agrupadas em sete maneiras ou graus de alteração física da leitura ou da superfície: páginas com significados ocultos; páginas anuladas (obliteradas); páginas cortadas, rasgadas, amassadas e perfuradas; páginas fragmentadas; páginas com camadas; páginas esculturadas (onde ficou agrupado Poemóbiles, 1974, de Augusto de Campos e Julio Plaza); e páginas costuradas e tramadas. Uma obra não precisaria, claro, pertencer apenas a um grupo, o que dificilmente aconteceria. Esta era apenas uma proposta da curadoria para demonstrar um problema temático de uma forma que ainda não havia sido feita (segundo Sackner, em The Altered Page, 1988, p.3 e seguintes). A exposição parece ter sido uma pequena aula sobre danos criativos à página, mesmo que não tivesse apresentado trabalhos mais polêmicos, integralmente desprovidos da possibilidade de leitura.

Essa exacerbação parece mesmo ganhar um realce a mais quando expressa por intermédio de mostras coletivas. Reuniões desse tipo quase que assumem o espírito dos bestiários, tal a variedade
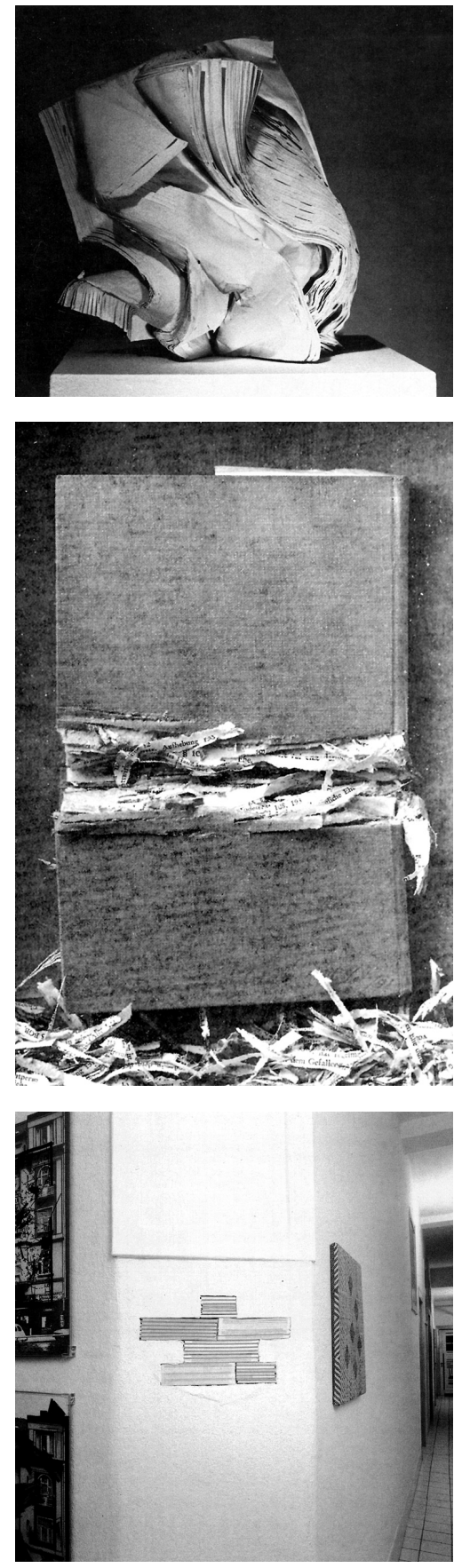

Helmut Löhr, dois Buchobjekt, ambos de 1981, e livros em parede, 1985 (reproduzidos em Helmut Löhr, 1985, p.11, 17 e 15). 
de conformações expostas. A pequena (em espaço físico) exposição coletiva The International Library, ocorrida em abril e junho de 1995 no Center for Book Arts, de Nova York, foi absolutamente marginal aos acontecimentos culturais do período na cidade, confirmando esse caráter um pouco recluso do livro-objeto. Ela foi montada como resultado de um projeto de Helmut Löhr, no qual ele enviava dois exemplares comerciais, por ele alterados e transformados, para artistas de quase todo o mundo. $\mathrm{O}$ intercâmbio propunha uma rede internacional de respostas artísticas através do livro. Cada participante deveria devolver um exemplar com novas alterações de qualquer tipo, formando uma biblioteca internacional de obras esculturadas, e revelando a diversidade da experiência humana (ver catálogo da exposição e Koob Stra, n. 11, 1995).

A exposição final contou com os trabalhos de 57 artistas, ${ }^{48}$ além do próprio Löhr. Nem todos eram artistas apenas voltados ao livro. O catálogo registra que

${ }^{48}$ Gloria Adrian, Hartmut Andryczuk, Frank Aoi, Ulrike Amold, Harriet Bart, Mark Beard, Douglas Beube, João Mauricio Carvalho (brasileiro), Gerard Charriere, Theodore Clausen, Byron Clercx, Anja Deerberg, Marylyn Dintenfass, Hilka-Frauke Duckwitz, Gerhild Ebel, Robert Ellsworth III, Felix Furtwangler, Lynn Geesaman, Albrecht Genin, G. W. Goettker, Giesela Groener, Thomas Günther, Koichi Hara, Ulrich Hinrichsmeyer, Basia Irland, Alain Jadot, Tom Joyce, Vesna Krezich Kittelson, Ben Kinmont, Jana Kluge, Laszlo Lakner, Hans-Peter Leicht, Marianne Lindow, Martha Little, Angela Lorenz, Scott McCarney, Renate Mergemeier-Teltz, Wes Mills, Wolfgang Nieblich, Jürgen Olbrich, Hinrich Peters, Eric Powell, Karin R'hila, Ric Schachtebeck, Daniel Schäfer, Sabine Sinzel, Keith Smith, Hartmut Sorgel, Buzz Spector, Stephan Stüttgen, Birgit Thelen, Martine Tremblay, Uwe Wamke, Hansa Wisskirchen, Lawrence Weiner e Anton Würth.
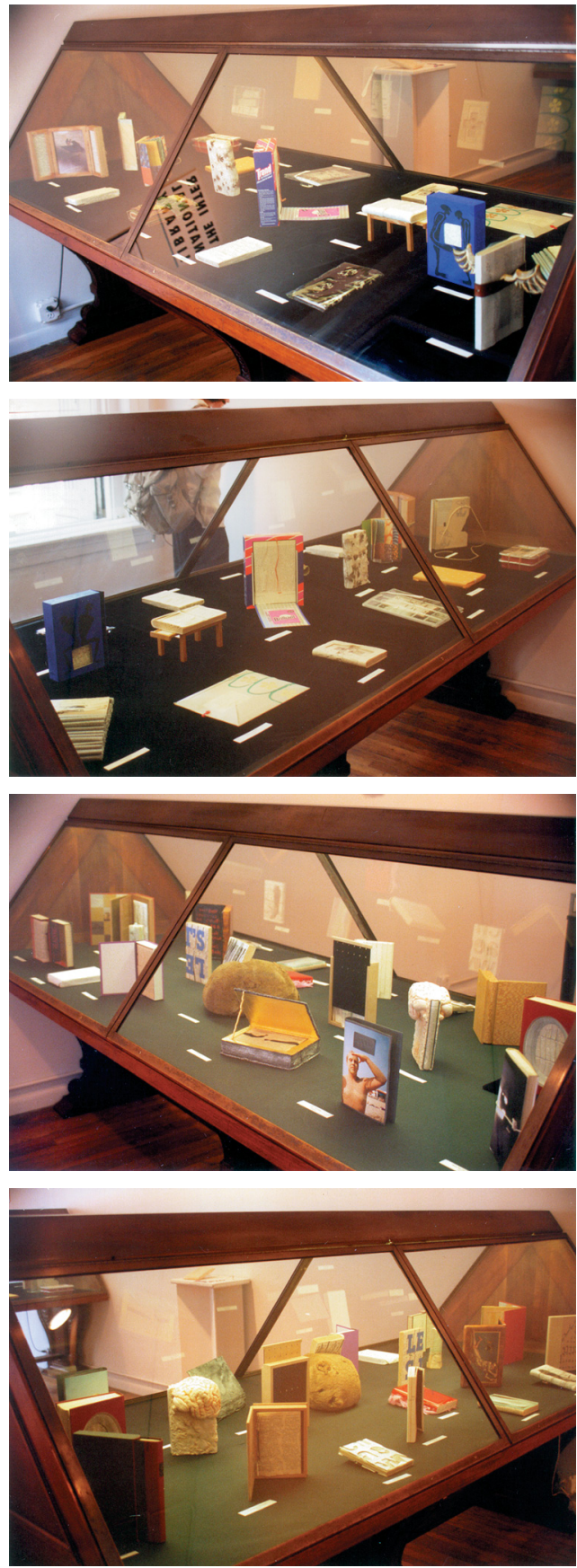

Exposição The International Library, no Center for Book Arts, Nova York, de abril a junho de 1995. O artista alemão Helmut Löhr produziu 112 intervenções que foram enviadas para novas interferências por 57 artistas de todo o mundo. 
havia "antropólogos, cenógrafos, encadernadores, botânicos, marceneiros, coveiros, presos políticos, ferreiros, linguistas, escultores, arquitetos, performers, curadores, sociólogos, editores, desenhistas de moda, fotógrafos, ceramistas, prateiros, advogados, psicólogos e fonoaudiólogos". Alguns livros-objetos receberam não mais do que uma encadernação expressiva, estetizante ou surrealisante, mas protetora. Mas praticamente todos os outros trabalhos expostos tinham sofrido algum tipo de injúria física, com frequência buscando metáforas. As violações foram funcionais ou semânticas: imobilização, obliteração, uso de cordas, pregos ou arames, novos rasgões e buracos, envelopamento, encaixotamento, incorporação em outros trabalhos escultóricos, "parasitismo" por outros bens de consumo, e até "encamisamento" por preservativo sexual. Toda coletiva tem seus altos e baixos e com essa mostra não foi diferente. Mas era estimulante. A energia bem-humorada dela estava justamente na "gritaria" de seus participantes, somada a um certo encanto radical. Foi uma amostra clara das tensões entre forma e significado no livro-objeto.

O catálogo da exposição retrospectiva antológica Book as Art, 1991, no Boca Raton Museum of Art,

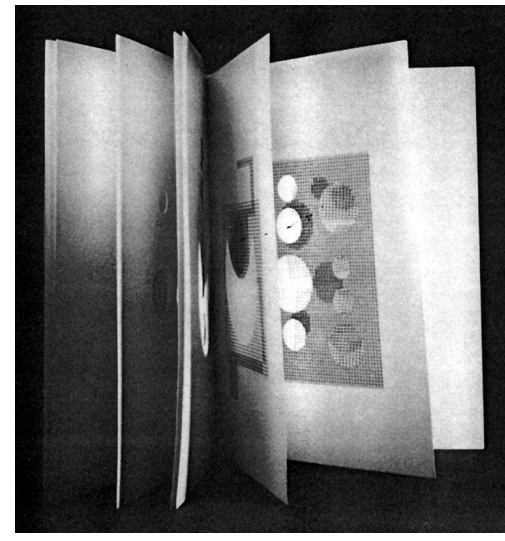

Jirí Kolár, 1963-69 (Bentivoglio, 1990, p.38).

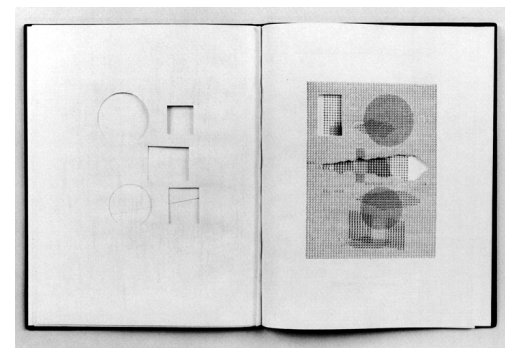

Jirí Kolár, sem título, 1967 (The Altered Page, 1988, p.19). Estados Unidos, apresentou o então recentemente falecido Harry Fritzius, através de um livro em sanfona sem título, feito a partir de sobras de cartas queimadas e desenhos de uma galerista sua amiga. Infelizmente o catálogo não reproduz a obra. O curador, Timothy Eaton, lembra que Fritzius entendia que, pela destruição da arte no seu sentido convencional, ele liberaria sua energia espiritual (Book as art, 1993, p.9). Seria essa uma ideia ligada ao sacrifício ou ao renascimento? No mínimo, ela instaura um novo início, um recomeço, uma destilação. A destruição pode mesmo ser um ponto de partida, não sendo, necessariamente, um fator negativo. Essa é também a opinião de Jirí Kolár.

Eu sinto que as ações de amassar, rasgar e cortar não são realmente destrutivas, mas são como um tipo de interrogação. É como se eu estivesse constantemente questionando algo. Eu sou curioso sobre o que existe atrás da página ou através do quadro. Biólogos não sabem nada de origem e função dos organismos vivos sem um microscópio para os ajudar a determinar corpúsculos vermelhos dos brancos. Eu também, necessito conhecer a composição dos corpúsculos de uma palavra. Essa aproximação levou-me na direção de uma gênese e de modo algum em direção a uma destruição. Foi, de certo modo, um passo para a germinação. (Transcrito por Kotik, 1978, p.10) 
Ao tratar de alguns livros com material têxtil e cabelos de Robbin Ami Silverberg, um artigo de Lois Martin os apresenta ou como fruto de uma luta com emoções que se recusam a ser contidas pela linguagem (e que envolveriam desespero e aflição); ou como meditações sobre a forma sagrada, o ritual e a blasfêmia; ou sobre a mutilação do livro; ou sobre a violência doméstica. $\mathrm{O}$ final de seu artigo reproduz uma visão sintética tanto da ambiguidade presente nesse tipo de obra (que afinal "é cuidadosamente feita de bonito papel artesanal"), como do fascínio de sua apreciação.

Primeiro eu estava pensando nas mutilações de Silverberg como o oposto dessa cuidadosa preservação; prevendo um como destruição e o outro como conservação. Mas eu vejo isso agora totalmente diferente. Eu repentinamente imagino a lâmina precisa de Silverberg como as tesouras afiadas dos fazedores de colchas recortando uma peça nova de boa metragem, dividindo-a em pedaços. O impulso parece perverso, até que se veja os pedaços compondo um novo trabalho. Mas então novamente, talvez isso seja perverso, tão perverso como uma citação. (JAB 10, 1998, p.28-29)

O livro vive a glória e sofre o ônus de representar a base da cultura universal. Assim, não é de estranhar que ele participe de uma infinidade de ações passionais ou performances ensaiadas que o destroem de todas as maneiras. John Latham, nos anos 60 , produzia suas "esculturas infames", por ele apelidadas de skoob (ou book em ordem inversa), baseadas na mutilação. A uma pilha de livros (skoob tower) ele botou fogo, numa cerimônia ritual

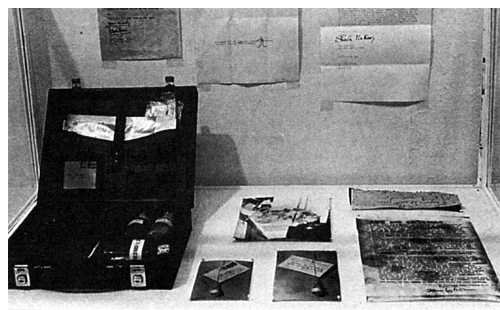

John Latham, Art and Culture, 1966, reproduzido do livro de Lucy Lippard, Six years: the dematerialization of the art object from 1966 to 1972 [...], obra clássica do registro da arte contemporânea.

Lippard fez parte do grupo de fundadores da livraria Printed

Matter, de Nova York, em 1976, juntamente com Sol LeWitt, Edit DeAk, Walter Robinson, Carl Andre, Pat Steir,

Irena von Zahn, Mimi Wheeler e Robin White.

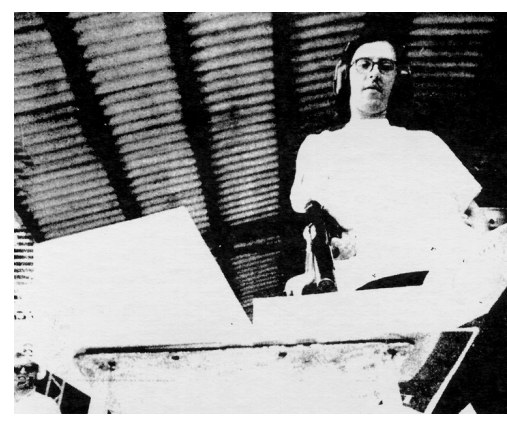

Nuno Ramos, Balada, 1995 (reproduzido no catálogo Livro, conforto e narcisismo, 1996, p.1). próxima ao Museu Britânico. Em 1966 ele retirou Art and culture, de Clement Greenberg, da Biblioteca da St. Martin's School of Art. Para a etapa seguinte, convidou um grupo de amigos, estudantes e críticos, mais o escultor Barry Flanagan, para ajudarem a mascar pedaços rasgados das páginas do livro. Depois de cuspidas, as páginas mastigadas foram colocadas numa garrafa com ácido sulfúrico a $30 \%$. Após virar uma forma de açúcar, foi neutralizado com bicarbonato de sódio e acrescido de uma levedura, na qual fermentou por alguns meses. Devolvido à biblioteca, o "livro" foi rejeitado. O evento biblioclasta gerou um subproduto: uma maleta de couro contendo a garrafa, os restos da "cultura" e a carta de suspensão do seu cargo de instrutor (Lippard, 1997, p.15 e 16, e Drucker, 1995, p.360 e 361). 
No Brasil, ações ou gestos mais ou menos genuínos também ocorreram. Lygia Pape revela o fim de uma obra de Reynaldo Jardim.

Em 62 ou 63 o Gullar resolve aderir a uma ideologia política e o Reynaldo Jardim o acompanha. Os dois entram pro CPC (Centro Popular de Cultura). Principalmente o Gullar, que renegou toda a obra neoconcreta. O Reynaldo Jardim chegou ao ponto de jogar fora aquele livro, Infinito, um livro belíssimo sem começo e sem fim. Jogou pela janela o único exemplar. Danou-se porque nunca mais se soube do livro. Foi carregado pela Comlurb [empresa pública recolhedora de lixo] da época, foi literalmente para o infinito. (Entrevista em Cocchiarale e Geiger, 1987, p.158)

Também eventos não-expontâneos ocorreram, alguns mais agressivos, outros com humor. Em São Paulo, 1995, Nuno Ramos deu o acabamento de seu livro $B a-$ lada, disparando nele com uma pistola 45, como gesto performático (Livro..., 1996, p.1). Também pelo fagismo existiram homenagens ao conhecimento ou críticas à imposição cultural: bolachinhas com palavras, sopa de letrinhas ou livros em forma de bolo. Como peça avulsa, deve ser lembrado o Livro de carne, 1977, de Artur Barrio. Realmente de carne, na primeira versão ela foi feita por um açougueiro francês a partir de lâminas muito finas de carne unidas por um barbante. Era manuseada diretamente pelo espectador. Ela se insere na produção do artista de fim dos anos 60 e início dos 70 , agressiva e contrária ao mercado de arte e inserido nos piores momentos da ditadura militar no Brasil. Desse período são marcantes o uso de lixo e restos perecíveis em manifestações e trouxas ensanguentadas em eventos de rua. Existe ainda uma versão em cartão madeira (ou cartão pinho ou

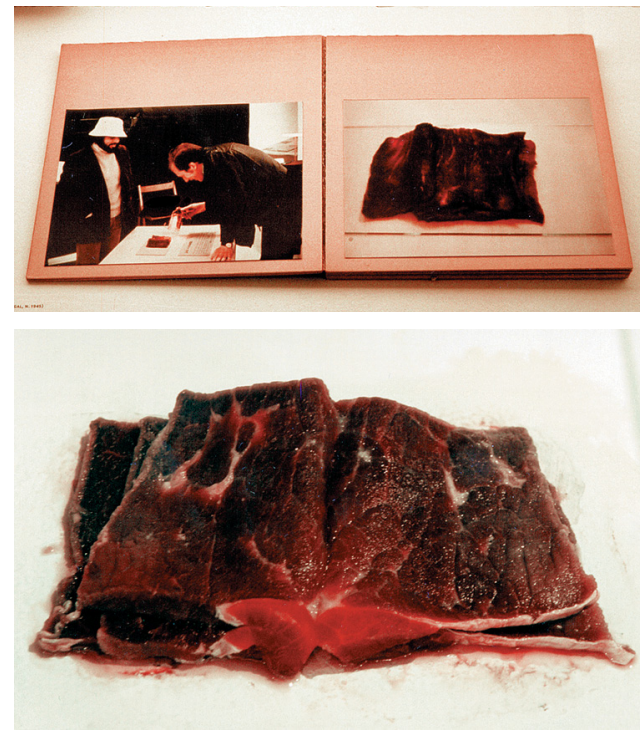

Artur Barrio, Livro de carne, versão em cartão de 1979, e versão para a XXIV Bienal de São Paulo de 1998.

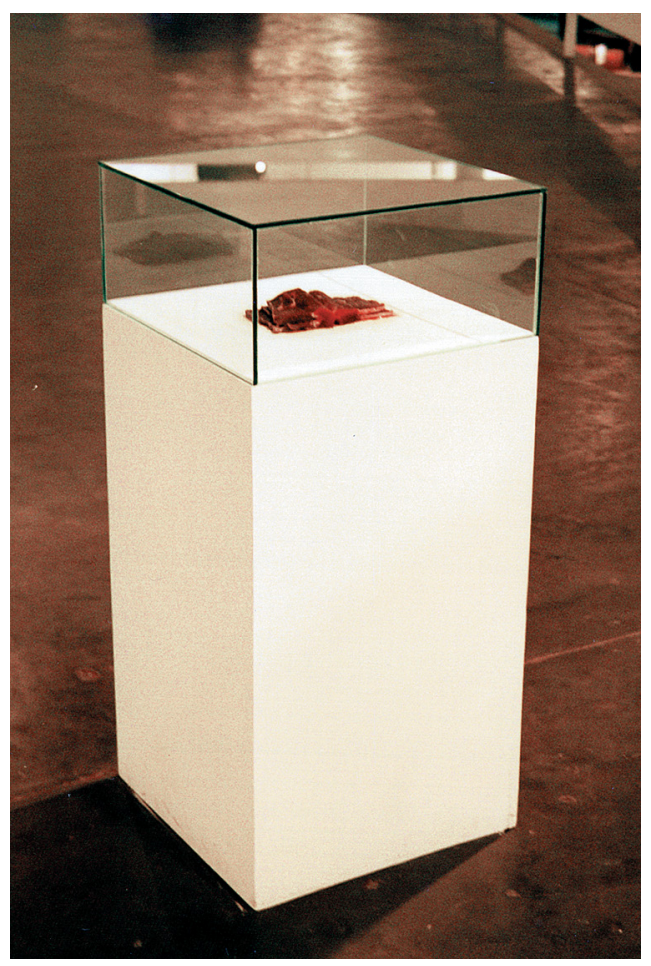

Artur Barrio, Livro de carne, apresentação na XXIV Bienal de São Paulo de 1998. 
pinheiro) e fotografia, com tiragem de cinco exemplares, de 1979. Foi refeito em 1998, para a XXIV Bienal de São Paulo, pelo próprio Barrio, mas a partir de uma peça única de carne. De tempo em tempo a peça em exposição era substituída por uma nova, e ficava separada do público por uma vitrina de acrílico. Agora num país democrático (mas ainda com fome), ele padeceu sob o espalhafato antropofágico do layout do evento. Mal contextualizado, o novo Livro de carne ainda causava surpresa para o público em geral. Talvez diminuída pela banalização da violência na mídia, a surpresa ia do nojo à pilhéria. Mas felizmente, demonstrações de indiferença eram raras.

Se a arte evolui por oposições (como clássico e romântico, por exemplo) e exacerbações (como maneirismo e rococó), por que não procurar esses parâmetros no estudo de amostragens menores, pontuais no livro de artista? Penso que voltaríamos, aqui, a Edward Ruscha e Dieter Roth. Havia neles o método na produção e constância suficiente para a identificação de um corpo de trabalho. Além disso, eles estavam inseridos em contextos culturais bibliólatras (anglo-americano e germânico) que eram muito ricos em precedentes artísticos. Tanto em Ruscha quanto em Roth esteve presente o gesto da renovação, por algum grau de rompimento ou desconstrução. Em Ruscha a ruptura é mais gráfica, envolvendo a destruição da estética fotográfica e da lógica sequencial. É, por isso, mais sutil, determinando a preferência que alguns têm pelos seus livros em detrimento da sua pintura.

Para a exposição temática, retrospectiva e coletiva Scene of the Crime foi comentado o estilo de Ruscha, através de Royal road test, 1967, livro feito com a colaboração de Mason Williams e Patrick Blackwell. O projeto parte de um evento mínimo. Ruscha dirigia um Buick ano 63, a 145 quilômetros por hora na US 91 (região do extremo oeste da Rota 66), com seus amigos. Às $17 \mathrm{~h} 7 \mathrm{~min}$ Williams arremessou pela janela do carro em movimento uma máquina de escrever Royal. Após parar o carro, Blackwell documentou os destroços.

Royal road test (1967), o livro de 62 páginas que Ruscha reuniu de seu "experimento" em destruição, tem o aspecto de um manual forense. Fotos preto-e-branco inexpressivas descrevem fragmentos da máquina de escrever despedaçada in situ, acompanhadas por legendas fatuais lacônicas como "Ponto de impacto" ou "Ilustração mostrando a distância que os destroços percorreram".[...] O que esse "teste" representou com uma máquina de escrever, uma máquina que produz caracteres decifráveis ao serviço do discurso inteligível, não parece incidental, nem a marca de fábrica "Royal" [régio, majestoso, real]. Arrebentando com essa máquina contra o cascalho sem significado, Ruscha expressou o violento falecimento de muitos sistemas simbólicos que encerram hierarquias "reais" de um tipo ou outro - especialmente entre eles a supremacia da linguagem como um meio de comunicação. (Rugoff, 1997, p.59-61)

Mas certamente a obra de Dieter Roth é mais visível nesse aspecto. As "salsichas literárias" de Roth, feitas com tripas embutidas com papel macerado e fervido, são alguns dos mais curiosos exemplos de mutilação de livros. Solitário, obsessivo, temperamental em relação a museus e instituições, com raízes no construtivismo suíço, mestre nas técnicas de impressão e em contato com os artistas Fluxus, Roth tem seus livros determinados por sua concentração na redefinição da materialidade (Dieter..., 1998, p.14) e 
na tendência ao uso de elementos que transmitem conteúdos como destrutibilidade e fragmentação. Iniciou seus livros com as perfurações em páginas coloridas, em obras de 1956 e 1957, preocupado com as qualidades espaço-temporais. A partir daí, ele se divide na fundação e participação do livro de artista gráfico e no incremento do livro-objeto plástico (como nas capas que faz para suas obras). Ele junta à linguagem pictórica narrativa o uso provocativo da materialidade concreta (Dieter..., 1998, p.20 e seguintes). $\mathrm{O}$ seu construtivismo tem um opositor dialético no seu interesse destrutivo, ampliado a partir de opiniões como a de Mondrian que, apesar de ter trabalhado pela relação harmônica, numa de suas últimas cartas (em 1942) declarou que o elemento destrutivo é muito negligenciado na arte (ver também em Chipp, 1988, p.368). Roth também se declarou muito impressionado, em $1960 \mathrm{com}$ as máquinas autodestrutivas e agressivas de Jean Tinguely. Ficaram famosas as citadas salsichas literárias de Roth, Literaturwurst, aproximadamente cinquenta, numeradas e assinadas, feitas de páginas picadas do Daily Mirror, do Spiegel e de vários livros, com destaque para os vinte volumes das obras de Hegel. A tripa era enchida com uma massa temperada do papel com gelatina e banha, com o rótulo recortado do original. A deterioração também fazia parte de sua obra, com a presença de chocolate, carne, ovos, sucos de frutas ou pão em esculturas ou mesmo gravuras. Eram projetos que consideravam a fermentação como integrante da mutação até a destruição pela multiplicação de microorganismos.

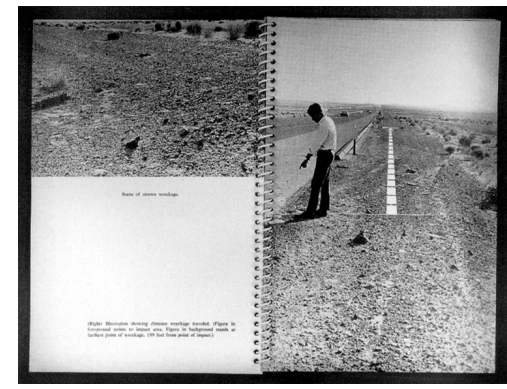

Edward Ruscha, Royal road test, 1967 com a colaboração de Mason Williams e Patrick Blackwell (Drucker, 1995, p.266).

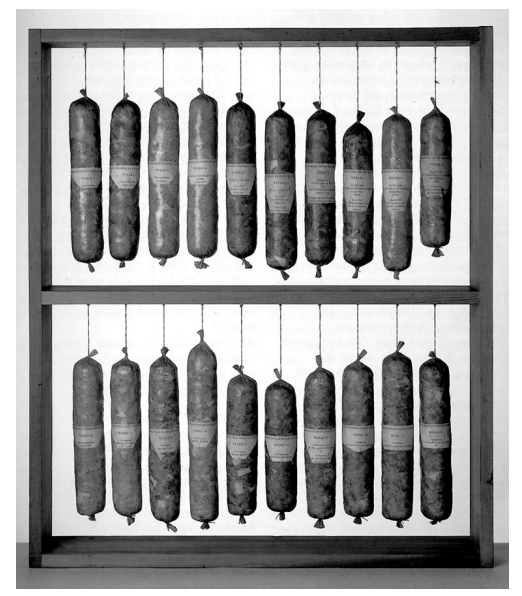

Dieter Roth, Georg Wilhelm Friedrich Hegel: Werke in 20 Bänden, 1974

(Archiv Sohm, Staatsgalerie Stuttgart; Dieter Roth, 1998, p.33).

Em entrevista para Felicitas Thun, alguns meses antes de seu falecimento, ele faz um grande relato desses aspectos do seu trabalho (Dieter..., 1998, p.143-144). Acho que a resposta a uma das perguntas deve ser transcrita por inteiro, pelas informações que traz e pela escassez de material sobre Roth.

FT: Destruição como um método da arte para a expansão das técnicas artísticas?

DR: Eu passei por algo em 1950, algo que eu tinha experimentado como uma criança, tenho certeza que você sabe. Desenha-se alguma coisa e inicia-se a borrá-lo até se estar num frenesi. Não se pode parar e pinta-se até estar tudo totalmente destruído. Se você experienciou isso você 
provavelmente irá entender o que eu fiz durante minhas fazes de lambuzos [Schmierperiode]. Eu procurei um velho impressor experimentado para lições. Ele trabalhava numa gráfica que imprimia estampas litográficas e cartões, Kummerly e Frey - eles ainda imprimem cartões mas em offset. Antes, os cartões costumavam ser desenhados na pedra pelo litógrafo e então impressos da pedra. A prensa litográfica encerrou as atividades em 1950/51 quando eles passaram para a impressão offset. Mas eles ainda tinham velhos impressores alemães experientes, que eles não podiam mandar embora porque estavam sob contrato. Bem, os proprietários da impressora convidaram artistas de Berna para imprimir de graça e tomar lições dos velhos cavalheiros. Eu também fui lá e trabalhei ao meu modo. Havia esse velho impressor que ria compadecido de mim, tão impertinente e tão estúpido, e dizia que não poderia trabalhar desse jeito. Eu tive uma recaída e me achei lambuzando de novo. Foi quando eu descobri - despejar ácido come a pedra e suja tudo nela! $\mathrm{O}$ estado de lambuzo voltou a acontecer, era o mesmo da minha infância. Eis como a primeira onda de lambuzo se apossou de mim. A segunda onda veio em algum dia de 1960, na Islândia. Inspirado em Bellmer, eu tinha começado a fazer desenhos pornográficos. Ao invés de ácido, eu simplesmente derramei leite azedo. Eu percebi que isso funcionava, que havia algo ali e que iniciava a mofar. Lambuzar e destruir são o resultado do meu fracasso em alcançar o que eu queria. Eis o porquê disso se tornar meu método de trabalho por anos. Foi o mesmo com a escrita. Eu tentei arruinar os primeiros "Scheisse Gedichte" (Poemas de Merda). O sentimento de que eu não podia fazer isso induziu-me a motivar os estudantes na América a arruinar até o trabalho tipográfico. De repente eu compreendi que talvez mesmo o quadrado negro de Malevitch tenha resultado de um sentimento de fracasso. Sempre se chega a algo que não se pode mais representar. De qualquer forma, eu sempre retornei à atividade naturalista como a descrição da vida diária ou das minhas alegrias e temores. Não se precisa ser habilidoso para isso. Discurso e um pouco de desenho são suficientes nesse particular. Isso se torna progressivamente mais simples. Eu evito a dificuldade. Meu trabalho tem tomado o rumo da descrição do cotidiano e do que existe mais abaixo disso.

Um pouco mais adiante, Roth complementa seu pensamento: "Eu não sou sempre bem-sucedido na expressão de sentimentos profundos porque os recursos técnicos às vezes tendem a ser enganosos. Eles tendem a transmitir harmonia ou uma correção que a situação não tem" (p.145).

\section{A leitura agonizante}

Os exageros às vezes sem propósito do livro-objeto dos anos 80 chegaram a constituir correntes. É possível mesmo localizar refrãos ou linhagens. Existem as séries de livros baleados, serrados, queimados, aparafusados, rasgados. Existem coleções de volumes afogados, empastados de tinta, de cera, de óleo. Existem grupos com páginas furadas, coladas, costuradas, revestidas. Poderia-se propor todo um diagrama taxionômico, com classes, ordens, famílias, gêneros e espécies. Houve mesmo uma experimentação apressada, enfadonha em muitos casos, que privilegiava uma criatividade escrava do material e da técnica. $\mathrm{O}$ seu maior problema era poder causar um engessamento na comunicação com o público, partindo-se do princípio que o artista queria comunicar. Em outras palavras, muitas obras não passaram de criações constrangedoramente chatas, se intrometendo com frequência entre projetos sérios e originais. 
Consultada sobre temas mais ou menos ligados a esse problema, Anne Moeglin-Delcroix não tem receio de afirmar sua preferência por livros mesmo.

[...] e porque os livros-objetos não são senão objetos divertidos, decorativos, repetitivos (quantos livros queimados, amarrados, cortados, dobrados, em mármore, etc.!), mas raramente são grandes obras plásticas. É claro que há alguns êxitos excepcionais, como os livros em chumbo de Kiefer, na Alemanha. Não creio, porém, que o livro-objeto tenha alguma importância artística atualmente como fenômeno de conjunto (não me refiro à importância que pode ter na obra de um artista em particular). ${ }^{49}$

E pouco antes da declaração anterior, ela fez coro aos defensores do livro.

Você já se questionou sobre o registro agressivo do vocabulário corrente no domínio do livro-objeto?

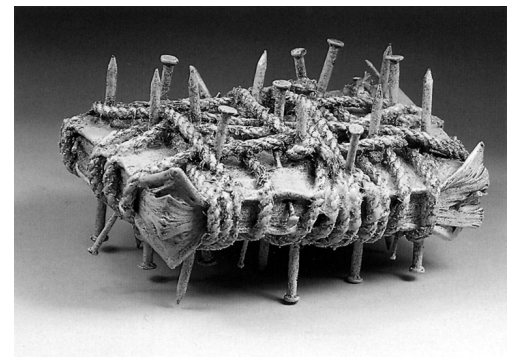

Barton Lidicé Beneš, Censored book, 1974

(Book Arts in the USA, 1990, p.10).

"Vou dizer-lhe como eu comecei tudo isso. Uma vez eu estava num trem para a Filadélfia, lendo uma biografia de Nixon, e passei a riscar o livro à medida que o lia. Quando cheguei à Filadélfia, tinha riscado todo ele. A partir daí, passei a fechar livros com pregos e a prendê-los com cordas." Veja você mesmo sua “violated page"! !50 Sou particularmente sensível a todo o vocabulário da destruição no livro-objeto. Por razões intelectuais e também políticas, sou totalmente contra a associação entre o livro e a destruição, ainda mais a destruição do livro. Para mim, o livro está ligado às ideias de salvaguarda e de respeito, de resistência à violência, e de liberdade.

O ponto extremo do livro de artista em geral é a obra objetual escultórica. Seu principal sinal de personalidade é o quase completo abandono da palavra escrita, juntamente com o total e absoluto abandono da condição de mídia. Suporte, sim, matéria plasmável, sim, mas pretensão de divulgação, não mais. Não são mais intermidiais. Pertencem apenas às artes plásticas, sem vínculo direto com a literatura, a comunicação social ou outros produtores de informação "legível". Salvo raríssimas exceções, são peças para museus e galerias. Estão atreladas ao grande universo da livro-arte (ou do librismo) porque, embora nem sempre sejam bibliomórficos, são sempre livro-referentes.

Muitos entendem essas obras como herdeiras dos livros de chumbo de Anselm Kiefer, considerando-as como associadas aos exageros pictóricos do neo-expressionismo dos anos 80. Por isso recebem, vez que outra, uma segunda qualificação: matéricos. Essa é mais uma palavra infeliz, já que tudo que não é desmaterializado é, por princípio, material. Mas esse termo teve seus momentos de sucesso. Como durante a $20^{\mathrm{a}}$ Bienal de São Paulo, 1989, quando de diversas pinturas escorriam gosmas, feltros com breu,

\footnotetext{
${ }^{49}$ Declaração para esta pesquisa, enviada em 17 de fevereiro de 1999. Tradução de Patrícia Ramos.

${ }^{50} \mathrm{~A}$ correspondência foi enviada para a França em português e inglês. O retorno veio em inglês. Entretanto, Anne Moeglin-Delcroix pediu para responder a entrevista em francês para facilitar a sua fluência.
} 
ceras e toda a sorte de resíduos, besuntando o piso. Angélica de Moraes definiu a pintura matérica pela sua capacidade de "emporcalhar" o chão.

Quadros que se desmancham ou não secam nunca, ameaçando o tapete de quem se disponha a levá-los para casa, são a característica da chamada arte matérica [...]. São obras feitas com combinações insólitas de materiais, que incluem resinas diversas, vaselina, breu, linhaça, esmalte e até mesmo tinta. Em resumo: tudo o que passa pela imaginação do artista e que possa criar o efeito o mais extravagante possível. (Veja, 29 de novembro, 1989, p.194-195)

Essa tendência também chegou ao livro-objeto, extrapolando ainda mais aspectos de maceração, degradação, fragilidade, precariedade, destruição. Normalmente se dá pelo espetáculo passivo, no aguardo da outorga da aura de obra de arte única. Muitas vezes são expressões dilaceradamente românticas e egocêntricas. Essa produção parece ter desgastado muito esse campo, que se ressentiria com a natural impaciência da crítica. Mas existem, também, resultados estimulantes, frutos de pesquisa comprometida, em tons mais baixos ou soluções mais amadurecidas. Digamos que, nesse caso, esses livros não chegam a ser tão matéricos assim, já que não pingam no tapete.

Artistas veteranos procuram e reconhecem a participação do livro escultórico como parte ativa de seu imaginário pessoal,
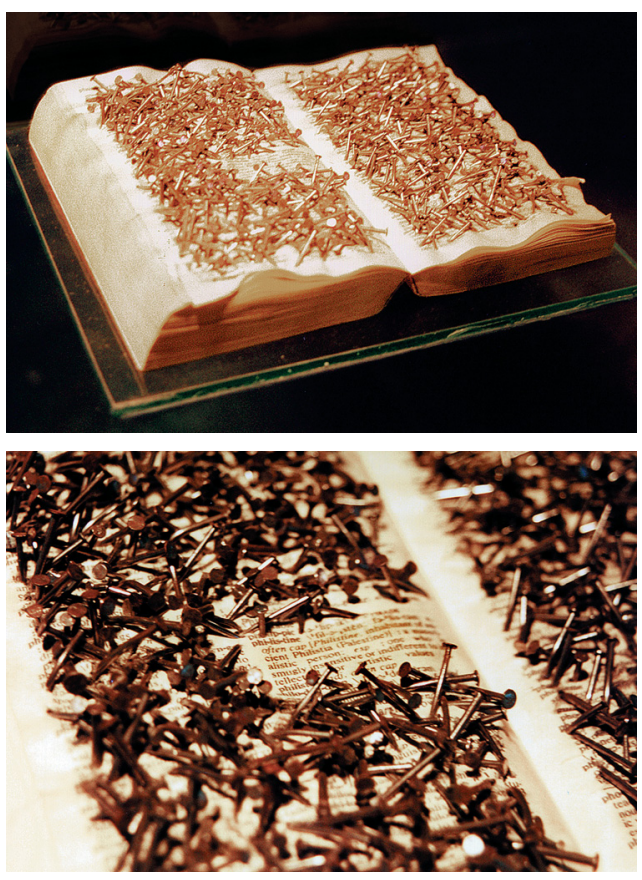

Khalil Rabah, Philistine, 1997. e integrada nas suas exibições. Bem como artistas jovens pesquisam a arqueologia de sua forma, do mesmo modo que confirmam seu uso como veiculador de mensagem e suporte de informação, sem abdicar do efeito pictórico e plástico. Entretanto, justamente no momento de maior expressão do material, retornamos à dissertação do tempo e da temporalidade. Ou completamos outro ciclo na faixa de Möbius. 
Para a exposição Cosmic-Maternal, em 1993 e 1994, no Brasil, Estados Unidos e Japão, com uma artista de cada país, Lia do Rio (Cardoso Costa) apresentou um conjunto de obras e instalações nascidas de seu vínculo com a natureza. Entre as obras, estava um livro inteiramente feito de folhas secas de cacaueiro, apresentado sobre um grande atril ou suporte de madeira (nas suas palavras, "igual aos usados para segurar o missal na igreja"). Seu texto para a mostra começa com uma afirmação categórica: "O mundo de um artista é um mundo sem palavras." O livro aberto, como é apresentado, tem $67 \times 98 \mathrm{~cm}$. As folhas são unidas por colagem contínua, umas às outras, sem nenhum suporte por trás. A forma de códice é obtida pela dobra das páginas em sanfona, com a última (a extremidade final) unida à primeira. Apesar da aparência, o livro não
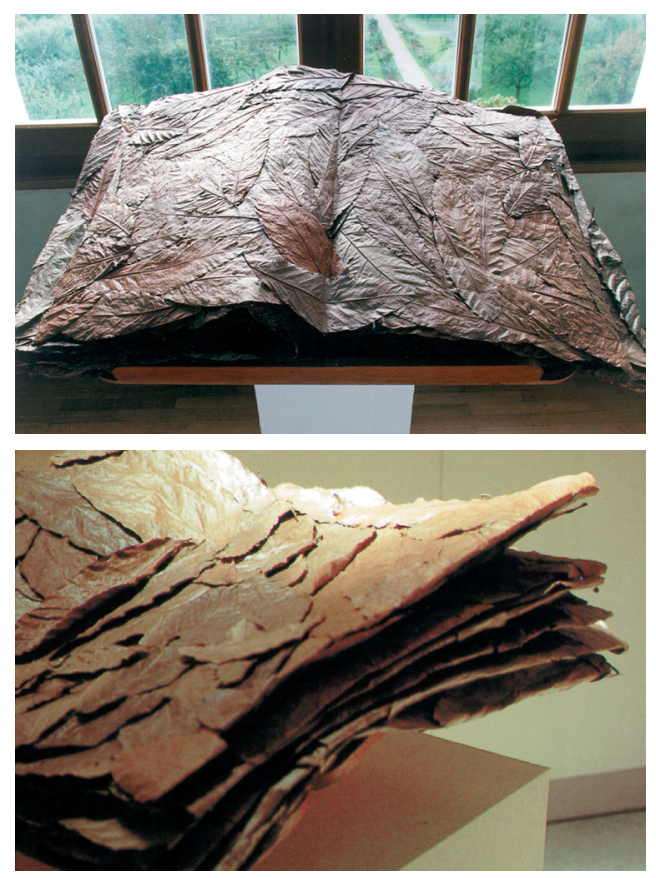

Lia do Rio, sem título, 1994 (fotos fornecidas pela artista).

é frágil porque as folhas são resistentes.

Mesmo sendo da mesma espécie botânica, elas apresentam diferenças sutis. "Umas são mais claras ou escuras; algumas se curvam; algumas são manchadas; umas são enormes; outras apresentam furinhos causados por insetos; algumas preservam o verde e assim por diante. [...] Essas folhas têm a textura e o ruído do papel." (Declaração pessoal, sem data.)

Em Lia do Rio, a materialidade é a afirmação de sua existência no tempo histórico e biológico: "Eu não uso folhas caídas para elucidar a natureza mas como algo que lembra passado e futuro" (pronunciado no simpósio Earth/Life and Art, transcrito no catálogo da exposição, p.27). Através dos atributos das folhas, Lia pesquisa vida, morte e transformação. O que está em acordo com suas outras atividades junto ao movimento Ação e Cidadania contra a Miséria e pela Vida e o Movimento Brasileiro de Artistas pela Natureza. Para ela, segundo sua apresentação no catálogo (p.11), o tempo deve ser sentido no presente: "Nós podemos lembrar o passado 'aqui e agora' e imaginar o futuro 'aqui e agora', e nós só podemos tomar decisões 'aqui e agora." Ela recorda que existe uma cápsula espacial saindo de nossa galáxia com informações sobre a terra. Entre elas, uma foto de uma mulher varrendo folhas secas sob uma árvore. E pergunta: "Por quê?"

Leila Danziger entende que resgatar o nome de uma pessoa assassinada concede-lhe, de volta, a sua humanidade. Esse foi o pressuposto de seus trabalhos elaborados a partir de 1995, e expostos em 1997 e 1998. Curiosamente, essa segunda exposição foi quase simultânea a uma mostra de obras de Anselm Kiefer, em São Paulo, que parece 
ser a sua maior influência, e sobre quem já elaborou dissertação. A mostra Nomes Próprios foi composta por livros-objetos colocados sobre carteiras (mesinhas) escolares carcomidas de cupim. Sobre cada um deles, pendia do teto uma lâmpada acesa. Os livros, exemplares únicos, receberam impressão rústica, desgastada, em páginas a serem posteriormente maceradas pela impregnação de óleo de linhaça, grafite e outras ações. As páginas parecem feridas. São ásperas, fortes e concretas, eloquentes. São gordas de óleo e com um cheiro forte e enjoativo. $\mathrm{O}$ formato é médio, entre o de um livro comum e uma pasta de arquivo. A cor predominante é o amarelado da ação do óleo. A escarificação da página não permite certeza quanto à técnica de impressão dos textos em preto (quase ilegíveis, na prática) e das imagens em alto-contraste. Pode ser tipografia ou serigrafia, ou ainda haver uso do xerox. Só a autora pode informar a técnica (é serigrafia). As páginas são unidas por cola e papel japonês. $\mathrm{O}$ trabalho é apresentado em ambiente com iluminação discreta.

Para Leila, seus livros são organismos de memória, o que praticamente a maioria dos livros é. Nesse caso, a memória é a do extermínio de judeus na Segunda Guerra, personalizada pelo registro de nomes de membros alemães da grande família Danziger nos anos do genocídio. Essas pessoas podem ou não ser suas parentes. Dura consigo mesma, ela acredita que a motivação é frustrada: "Constato que a recondução à singularidade e à individuação não se cumpre. [...] Sentidos breves e fugidios emergem no fluxo da história, ainda assim algo emerge, e é isso que me importa" (citado no catálogo O artista pesquisador, 1998). Leila quer conferir materialidade ao texto e à imagem.
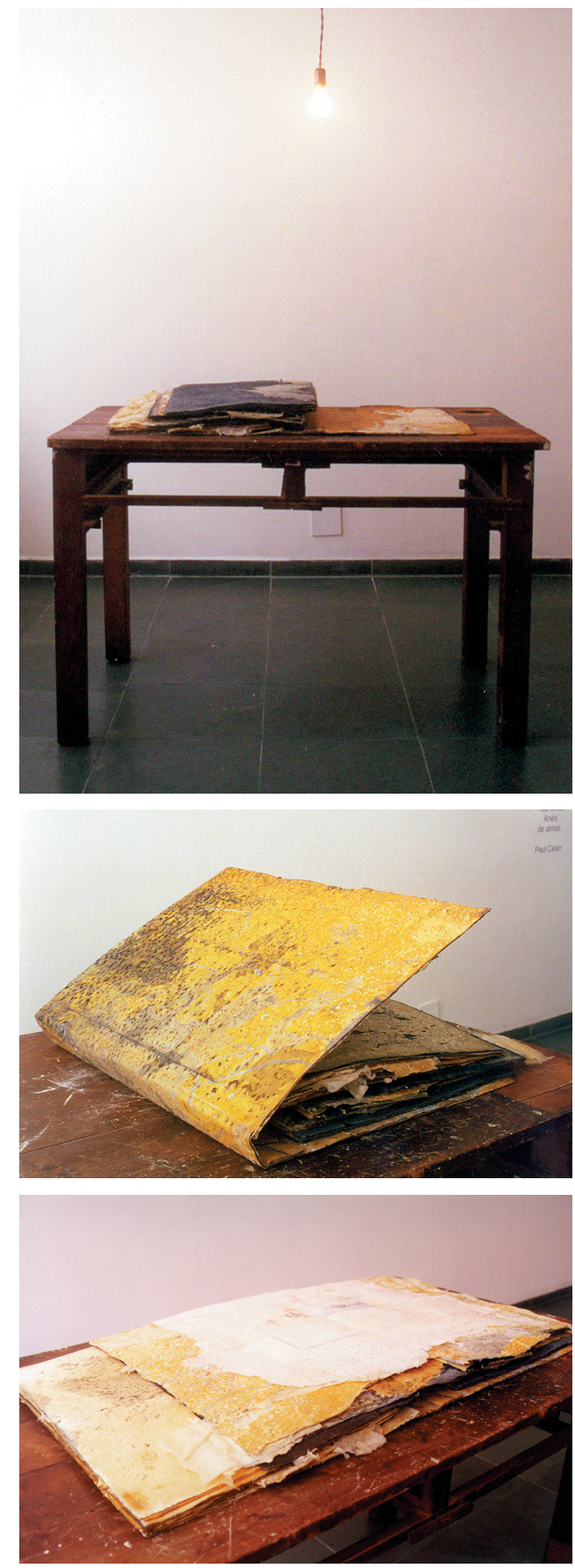

Leila Danziger, Livro da memória, c. 1997. 
Os livros solicitam o manuseio e, ao mesmo tempo, o dificultam ou mesmo o repelem. $\mathrm{O}$ que travaria eventualmente o contato são as qualidades específicas dos materiais: a densa impregnação do papel pelo óleo e a fragilidade de partes do trabalho causando a sensação que este pode desfazer-se a qualquer momento. Se já acreditei serem esses "problemas" a serem solucionados, vejo-os hoje como qualidades inerentes à natureza do trabalho.

E reconhece a própria escravidão ao precioso.

Permitir seu manuseio foi uma decisão difícil e progressiva. Mas quem sabe tocados pelo outro, os livros se completem, nunca em sentido definitivo, creio, mas entregando-se, como a um destino, a seu processo de transformação interminável.

Talvez o que mais intensamente permeie tanto os livros de Lia como os de Leila seja a permanência, ressemantizada, da arte litúrgica. Nos dois casos as obras recorrem a uma forma arquetípica, o códice, fruto da arte da encadernação praticada originalmente nos primeiros século da era cristã por sectários do Leste e Norte da África, e que ingressou na Europa por obra das atividades monacais. Mesmo na presença da temporalidade biológica em Lia e da obscenidade política terrena em Leila, ambas erigem sofisticados livros de culto, peças de sua liturgia pessoal, uma liturgia da imagem.

Trabalhar com o sagrado tem sido o projeto de Iolanda Gollo Mazzotti. Seus livros fazem parte de uma produção marcada pela pesquisa da instalação, com raízes barrocas e simbolistas, tensas, dramáticas e católicas. Seus livros podem ou não ser como códices. Se forem, serão sempre (ou quase sempre) referentes aos livros litúrgicos. Se forem distantes do códice, então lembrarão, mesmo que vagamente, véus, oratórios ou objetos
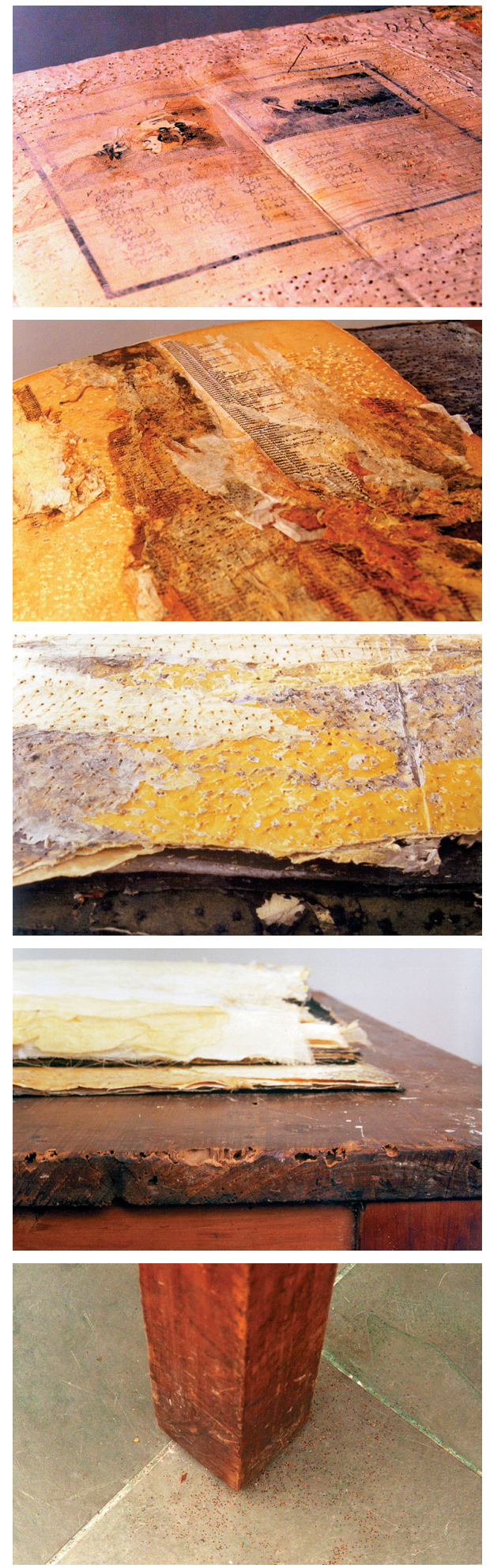

Leila Danziger, Livro da memória, c. 1997. 
de penitência e flagelo. Mesmo trabalhos "mundanos" guardam uma certa sacralidade, como na obra sem título feita de folhas de chumbo com banhos de prata e ouro, não polidos. Embora elaborado a partir da obra de Malevitch, numa primeira e apressada olhada imaginaremos um vínculo com as peças de prata do cerimonial da missa.

Os livros de Iolanda são elaborados a partir de técnicas e ofícios tão antigos quanto a religião: marcenaria, costura, encáustica, funilaria, forjadura e outros procedimentos (para as instalações, seu número amplia, com a presença, entre outras, da carpintaria e, claro, trabalhos de santeiro). Tractatus II - a confissão, 1993, tem $35 \times 34 \times 6 \mathrm{~cm}$, se considerado sozinho e fechado. Essas dimensões aumentam porque ele é usualmente apresentado aberto sobre um atril de madeira. Na sua elaboração foram usados chapas de alumínio, vidro, papel, madeira, cera e fotografia, além dos arames e pregos. A partir de um protótipo, foram realizadas cinco cópias. É muito pesado e nada nele é flexível. As páginas são placas metálicas que viram pesadamente, realçando a gravidade do folhear e seu desvelamento. Entre elas, uma imagem fotográfica em detalhe dos olhos de uma santa (Nossa Senhora da Luz? Santa Luzia?).

Tractatus $V$ é feito de madeira, lona (o material dominante), fio de cobre, cera e linha, no formato final de $46 \times 22 \times 5 \mathrm{~cm}$. A madeira é uma matriz para moldar placas de túmulos. Essa solenidade crepuscular ainda é ampliada pelo símbolo de Cristo em bordados incompletos, realizados pelas irmãs carmelitas de Caxias do Sul, que amigavelmente contribuíram com a artista. Horror vacui III ( 40 x 82 x $6 \mathrm{~cm}$ ) foi um protótipo para Tractatus VII.É composto de lona, madeira, parafina e pregos. As páginas de lona, longas e pesadas, guardam as marcas de sua progressiva destruição. $\mathrm{Da}$
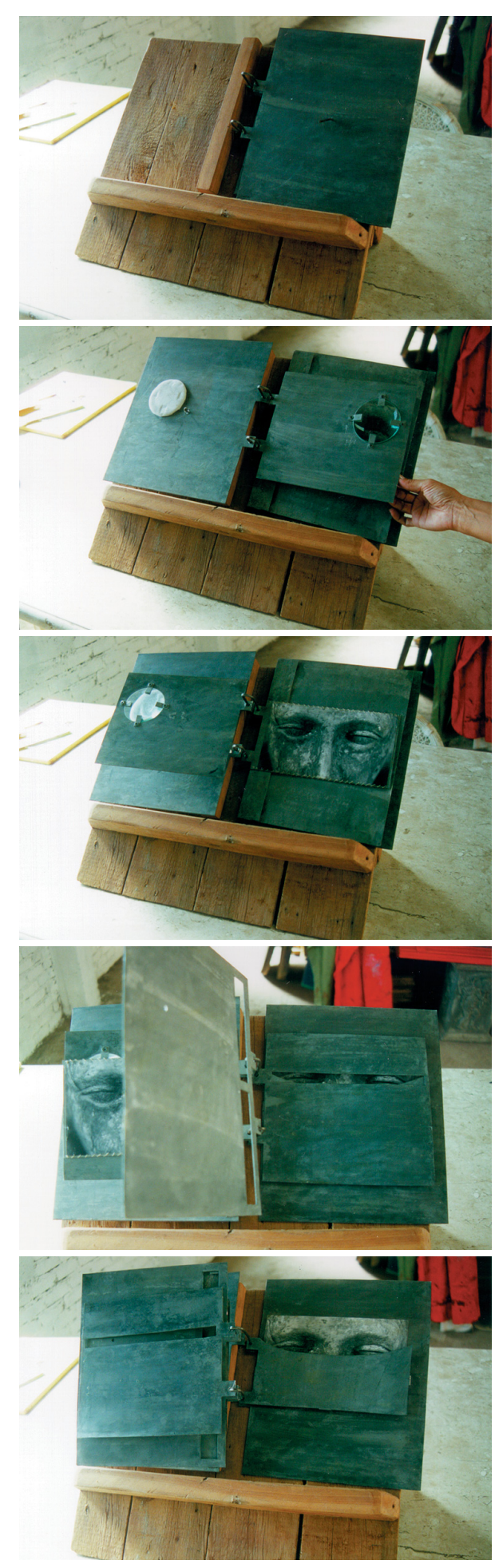

Iolanda Gollo Mazzotti, Tractatus II, 1993 (protótipo). 
última página (ou da "contracapa", ou da base - aqui a nomenclatura é difícil) saem pregos que dilaceram as páginas anteriores. E essa dilaceração é amplificada pela utilização de ácido muriático.

Para o catálogo de sua mostra Lux Perpetua, em 1993, quando os trabalhos acima foram apresentadas, Tadeu Chiarelli e Jayme Paviani fizeram as apresentações, ambos destacando que a obra de Iolanda não é kitsch. Chiarelli diz que ela evita "resvalar para o pueril, para o kitsch"e Paviani que ela apresenta um "excesso de efeito semântico que anula qualquer resquício de decorativo ou de kitsch". Por que reafirmar em coro o que não é? Seria difícil para o espectador erudito aceitar a presença de objetos previamente semantizados na expressão de uma emoção tão primária quanto o medo? Paviani diz que sua arte é "metáfora viva" que se coloca "na origem do simbólico, questiona o alegórico" e "rompe com as camadas de tradição para descobrir-lhes as origens, aquilo que estava perdido". Sobre os livros, ele entende que realizam uma "exaltação mágica".

Em Lux Perpetua II, oito livros-esculturas, [...] formam um conjunto de plasticidade e dinamicidade forte, limpa, perfeita. Os nomes em latim, e até em grego, as relações entre a confissão e os pecados da blasfêmia e da luxúria, as expressões "Horror vacui" "Ictus" e mais os Tratados das Sombras (I e VIII), isto é, do espaço privado de luz um simplesmente menos claro, permitem uma "leitura" do aspecto doutrinário e moral da experiência religiosa. O espectador é levado a refletir sobre o sentido (teológico e psicanalítico) da luz e da sombra como imagens da finitude humana e a meditar sobre as transgressões de preceitos e a necessidade de perdão para atingir a luz permanente.
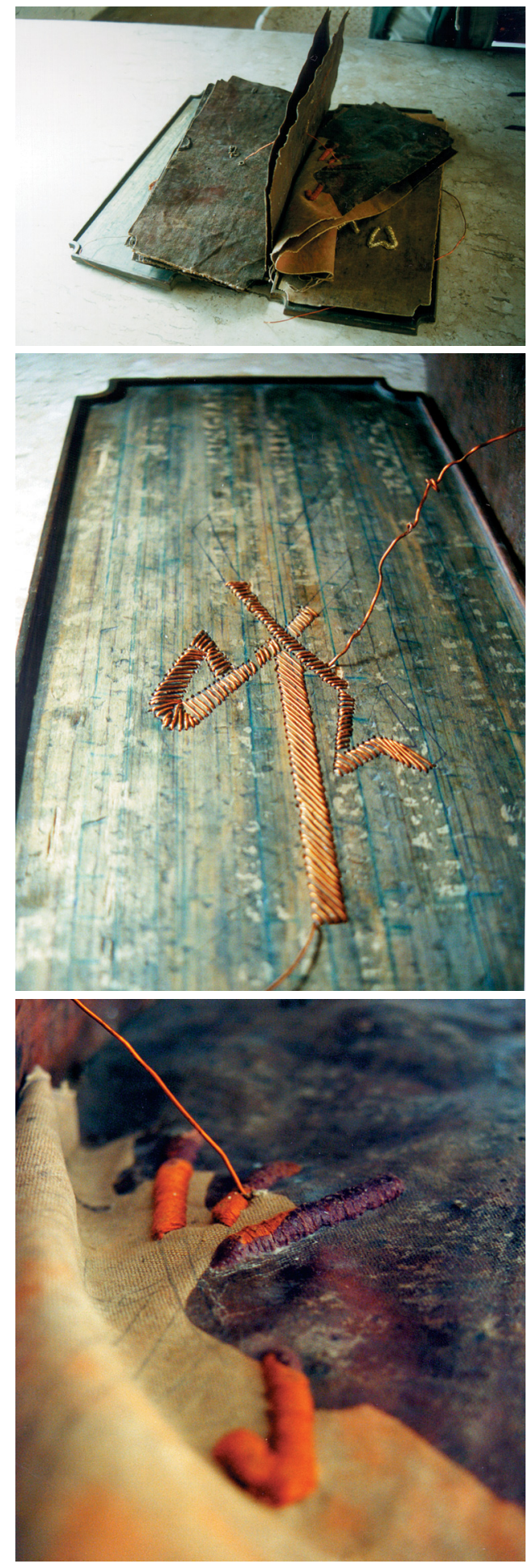

Iolanda Gollo Mazzotti, Tractatus $V, 1993$. 

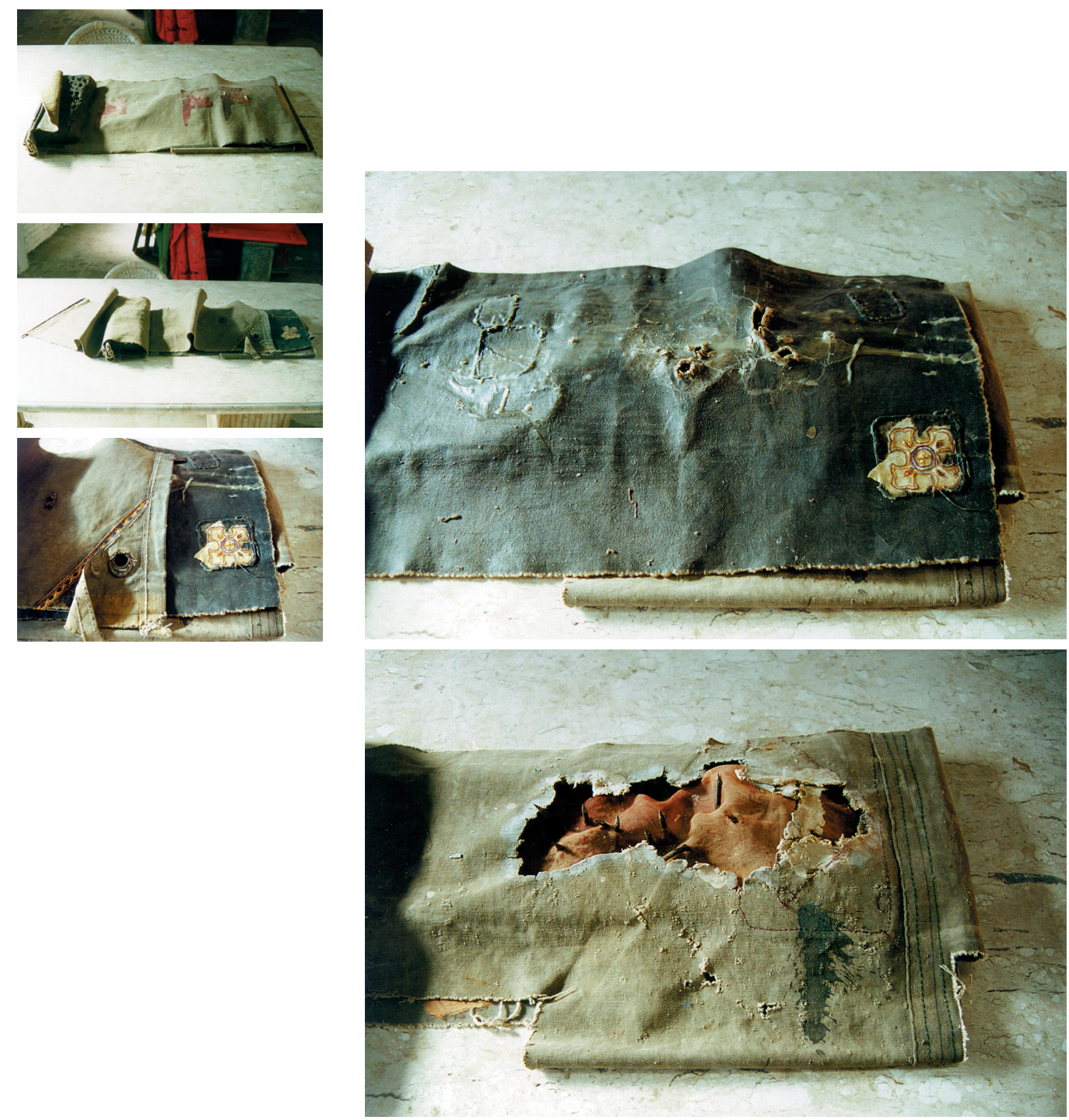

Iolanda Gollo Mazzotti,

Horror vacui III,

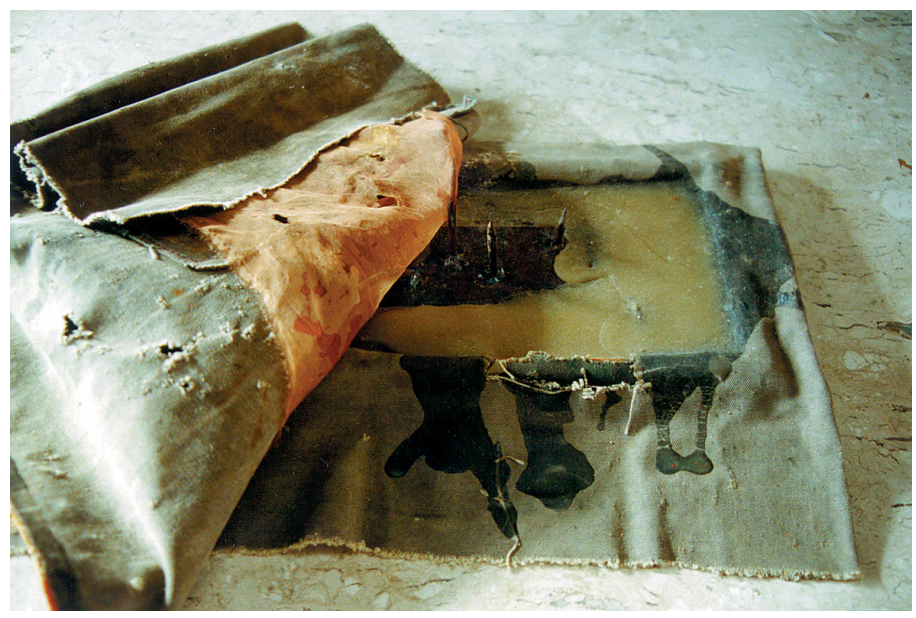


Para a exposição (Re)velar, de 1995, Paulo Herkenhoff fez uma apresentação em que destacou "a percepção entre dois extremos do excesso: a exacerbação da presença e a impossibilidade da luz".

$\mathrm{Na}$ exposição, certo objeto pendurado na parede funciona como painéis de aviso ou outdoor. São feitos com placas de metal perfuradas com pontos de luz (que correspondem ao alfabeto Braille) e veiculam uma aparentemente invisível mensagem imperativa: Toca-me. O toque, condição mecânica da leitura da escrita Braille, ganha aqui sua dimensão erótica. Torna-se uma alegoria da circulação do desejo e da afetividade, e implicitamente afirma a solidão e o abandono. [...] A exposição busca formar uma rede de significantes em torno de um olhar que ali não está, por arte dos excessos. Se já não temos o êxtase e o mito, também não basta a razão. Repentinamente toda a devoção paralisada se transfere para o campo da poética da percepção, e aí se abre para as
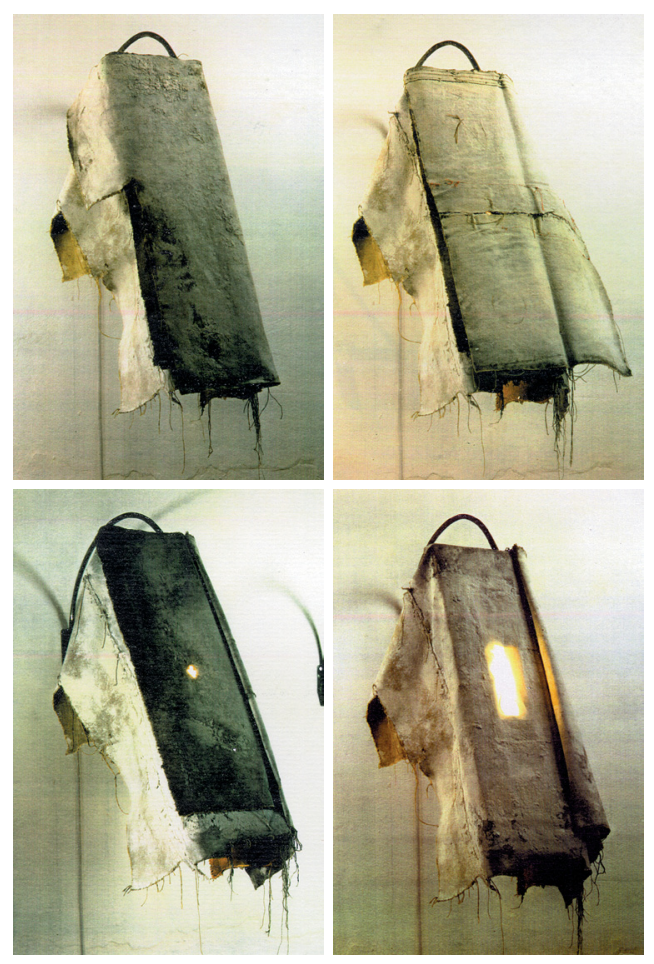

Iolanda Gollo Mazzotti, Livro da luz, 1997

(foto cedida pela artista). fissuras do desejo e da poética. Ocorre uma ironia grave. Luz excessiva que não alumia o olhar é como cegueira que não descreve a escuridão. Valem mais os índices mínimos de luz para os quais a visão me cegou.

A artista aceita que a luz excessiva fere o olhar e o cega. Mas que presença persecutória continua assombrando a fisicalidade do olhar de Iolanda, sem deixá-lo inteiramente livre? A sua arte nasceu do medo que sentia quando era criança das imagens de santos que seu pai colecionava. As imagens a encaravam de dentro do quarto onde eram guardadas (seu pai e seu avô também eram marceneiros e faziam altares). A diminuição desse medo, seu desafogo, será um dos impulsionadores da artista na geração de duas linhas de expressão paralelas: a criação de ambientes e a elaboração de livros-objetos. Com relação a esses últimos, poucos artistas contemporâneos brasileiros conseguem tão alto grau de pessoalidade e confissão autênticos, buscados do seu compromisso com o esclarecimento da opressão cristã sobre uma alma infantil. Existe uma certa mágoa nos olhares rebatidos de Iolanda. Afinal, que direito tem a religiosidade de causar medo?

Ao exemplo anterior existe a experiência oposta e pagã de Lenir de Miranda. Primeiramente desenhista e pintora, ela parece ter sido uma das mais prolíficas produtoras de livros-objetos do Sul do País nos anos 90. Seus livros são obscenamente plásticos. O texto que raramente aparece é apenas incidental e manuscrito, salvo nas raras obras gráficas. 
Em suas obras, ela costuma extravasar seu encantamento por James Joyce, o espectro literário que brota aqui e ali por detrás das pátinas e parafinas. Embora possa-se falar em narrativas sensoriais que eventualmente são acompanhadas de texto, não é propósito de suas obras uma narrativa locucionária. Anne Moeglin-Delcroix classificaria esses trabalhos, quanto ao aspecto formal e ao repertório, nos grupos dos livros condenados, parasitados e táteis. Ou talvez no grupo dos livros que não são livros. Lenir teria, assim, entre seus pares outros criadores de livros-objetos mais ou menos matéricos. Embora trabalhe com peças únicas, quando de sua mostra de Porto Alegre em 1994, ela publicou um livro catálogo, Autobiografia de todos nós, no qual textos seus (e de Joyce) propunham a tradução para o verbal de algumas de suas inquietações. Embora isso explicitasse a relação entre arte e literatura, a artista não deixou de privilegiar sua preferência pelo exemplar único: cada livro impresso teve o acréscimo de um fragmento de tecido tratado com tinta ou encáustica, personalizando-o.

Das caixas, gavetas e (por que não?) prateleiras de sua casa, saem obras às dezenas. Parecem brotar como gremlins, tanto pelo número, como pelo aspecto marginal e herege. A artista não aceita a obra de arte hierática. Caso se tenha excesso de cuidados no manuseio, ela insistirá: "É para pegar mesmo, assim...”, e demonstrará enfaticamente que o toque tem que ser decidido e interessado, desejoso de investigação. Está aí, talvez, uma das mais fortes ferramentas perceptivas da obra de Lenir: o tato. Antes mesmo de termos um de seus livros na mão, apenas pelo olhar pressentimos a importância da sensação tátil. Não existe aridez nas páginas, embora haja variedade de superfícies, desde tecidos leves até madeira ou alumínio, e variedade de texturas, do liso até o muito áspero. Nesse aspecto não existe
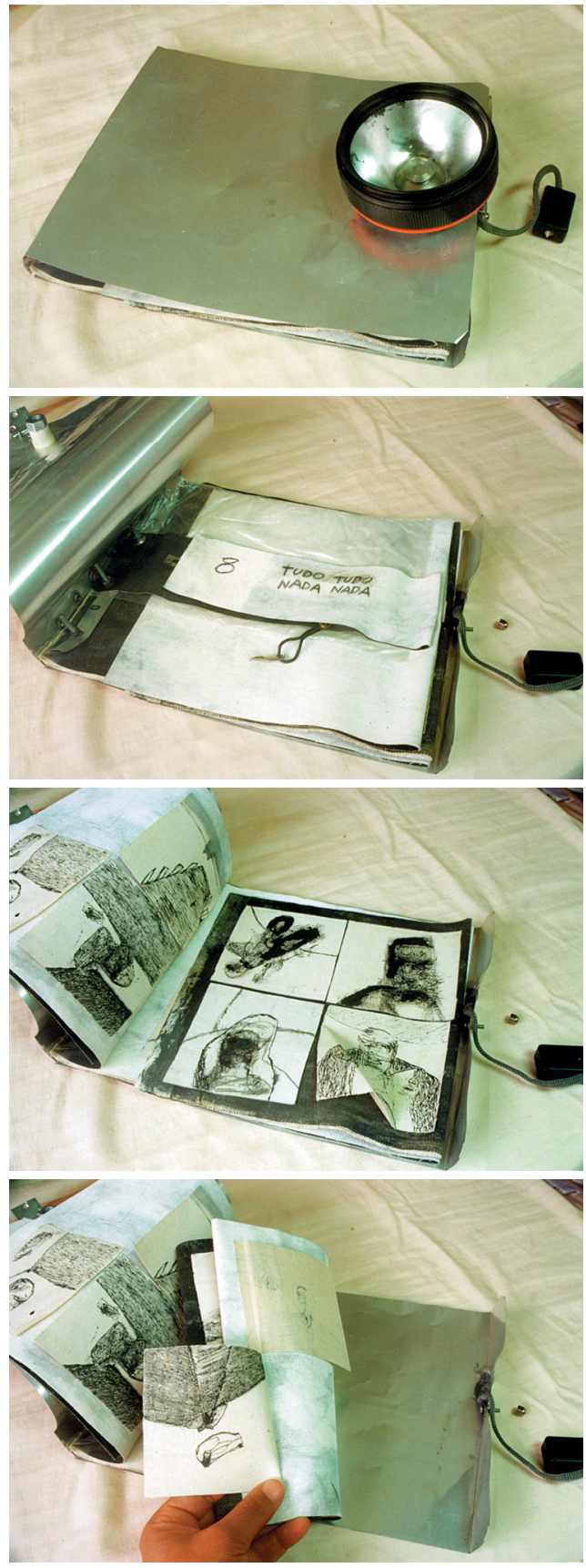

Lenir de Miranda, Livro do tudo-tudo nada-nada, 1994. 
sutileza. Os materiais são mais que evidentes, sem disfarces. A transmutação que eles sofrem, quando sofrem, pode ser mecânica, física ou química. Às vezes a sensação que eles transmitem é induzida. Há livros "quentes", com capa ou cobertura externa de feltro, por exemplo, sensação que é realçada por outros materiais térmicos. Ou livros "frios", revestidos de alumínio. Uma superfície mais áspera pode permitir uma impressão de ressecamento, enquanto uma cobertura parafinada ou com cera de abelha pode nos surpreender pela emulação de algo estranhamente úmido. $\mathrm{O}$ tato pode mesmo se confundir por essa sensação de umidade que o toque no tecido parafinado proporcionou. Alguns livros parecem ser, por isso, "molhados".

Os livros da artista guardam relação tanto com soluções figurativas, como com soluções abstratas. Como na presença justaposta de grafismos antropomorfos, linhas perspectivadas que lembram recintos, sugestões de água ou de mar, além de muitas manchas e texturas informais. Lenir se diz uma expressionista. Talvez sim, mas num sentido cauteloso, periférico. Ela seria, então, uma expressionista construtora? Em suas construções em assemblagem, uma geometria, que absolutamente não se oculta, diagrama no plano e no espaço as superfícies, os objetos e o ar atmosférico entre eles.

De outra forma, todo livro tem ressonâncias em outros livros. Analogias formais são decorrências autobiográficas: oceanos, figuras humanas fracionadas ou não, perspectivas de celas, fios de luz, condutores de energia, cera de abelhas, ferragens, cetim, citações (Miranda, 1994, p.12).

Maciez e dureza são outras presenças sensíveis em sua obra. Em particular a dureza, não só presente nos objetos acrescentados ao
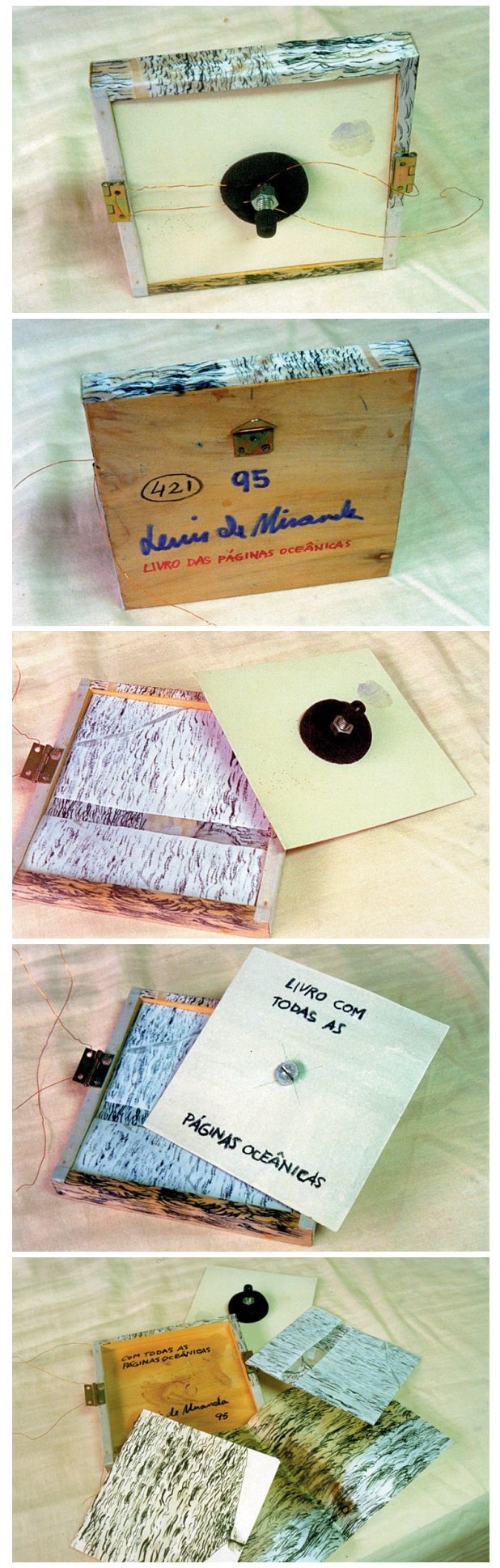

Lenir de Miranda, Livro com todas as páginas oceânicas, 1995. 
livro, mas nos elementos de fixação ou articulação. Essa dureza entra em contraste com as superfícies moles e múltiplas, de diversas texturas e tessituras. No caso das capas duras - aqui realmente duras, de madeira com dobradiças -, não há como deixar de lembrar de oratórios portáteis pessoais, pelo aspecto e pelas anexações como relicários. Mas serão sempre relicários pagãos ou mundanos.

Nos livros-de-artista o sincronismo é uma das medidas constantes do processo. [...] Para tal, algum livro-de-artista traz um coador, de brinde, ou um visor de porta olho mágico, teoricamente à disposição de todos. Assim, a linguagem de um livro tradicional é subvertida, reformulada, numa dobra do suporte página, num vinco inesperado, num filtro acoplado ao plano de imagens bidimensionais. Ou a uma palavra qualquer, contagiada de passagem, a qual, à medida que aparece, já não é mais qualquer, pois tem sua aparição comprometida, crítica. (Miranda, 1994, p.20)

Entre os livros moles, há o Livro da pintura, um objeto pictórico elevado a uma potência algo holística, sugestão de tratados apócrifos. Nele não há uma capa real, nem no sentido tradicional, nem na compreensão da moderna encadernação criativa. Mas ele abre e fecha também por dobradiças, porcas e parafusos, ou outros apetrechos. Esconde e revela enquanto nossas mãos desfrutam o contato físico do contraste entre o metal e o tecido impregnado, e especialmente com as placas de nata de tinta. Ou enquanto desdobramos e reviramos suas muitas possibilidades. Ficamos tentados a ser simplistas e imaginar uma pintura com sombras plenas e absolutas, com luz verdadeira e escuridão controlada. Uma pintura que desloca a luz e desloca o ar, porque tem força gravitacional. Inversamente menos leve que o pano e talvez tão pesadas quanto as ferragens, as natas de tinta comentam o pictórico, a meu
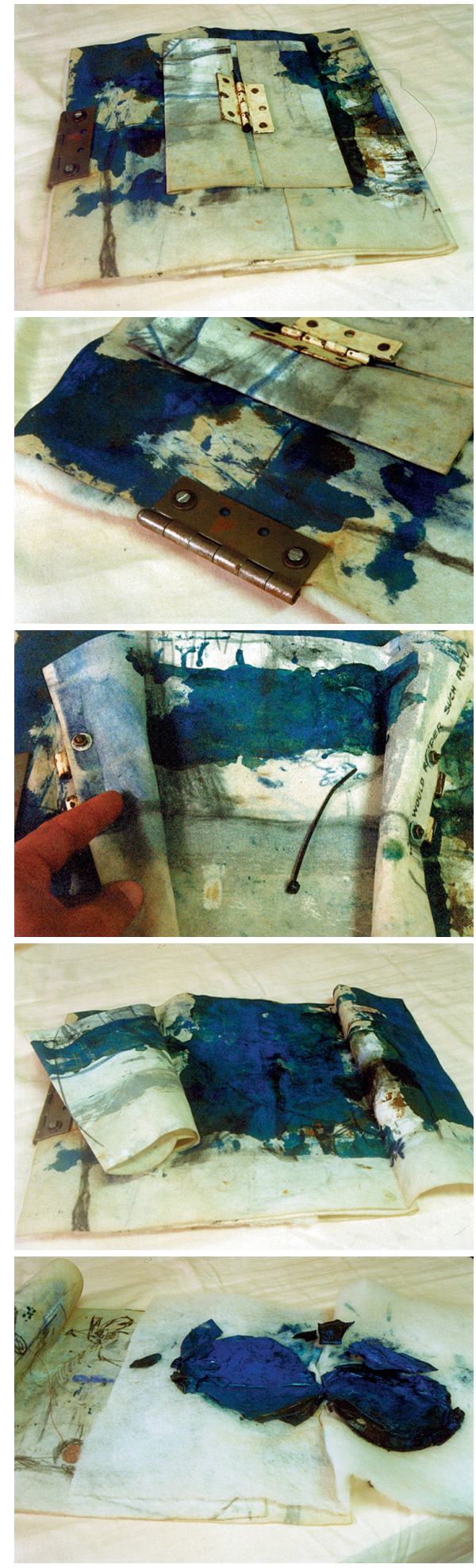

Lenir de Miranda, Livro da pintura, 1993. 

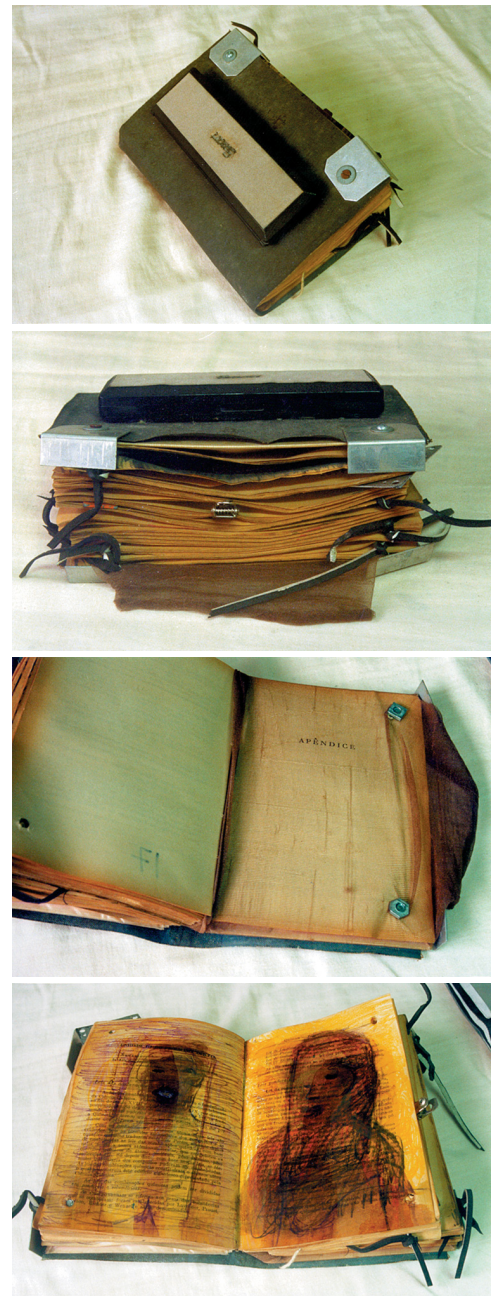

Lenir de Miranda, Livro com funil de Buchner e decantação, 1993.
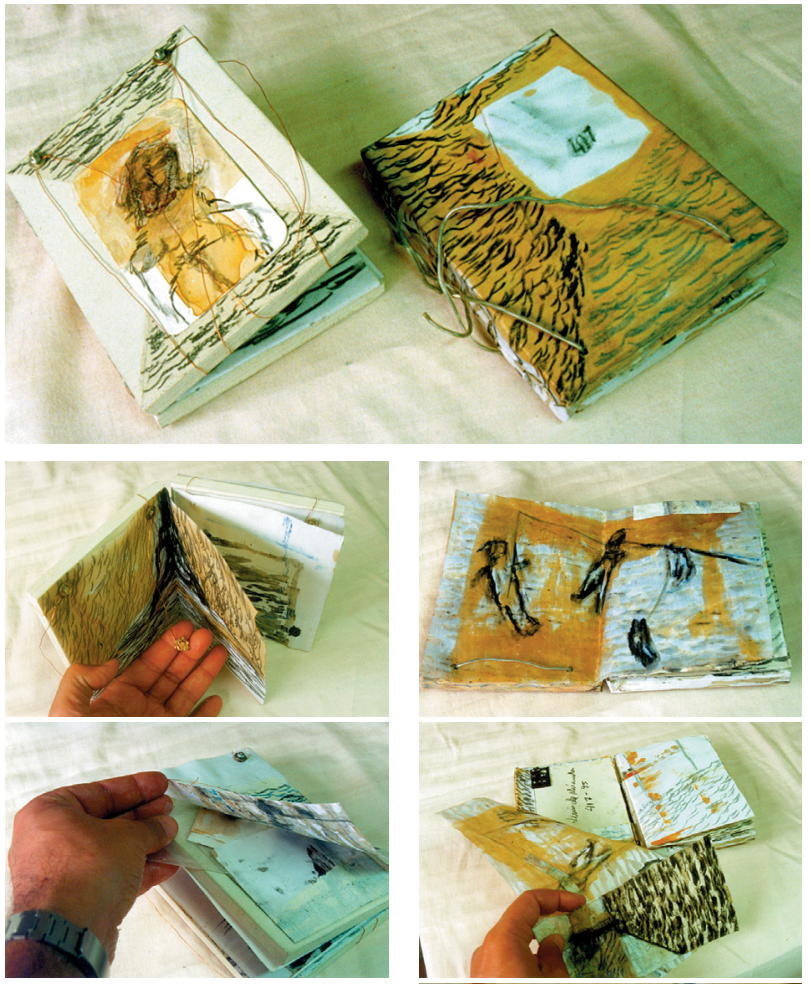

Lenir de Miranda, Livro das duras palavras (esquerda)

e Livro do quase invisivel (direita), 1995
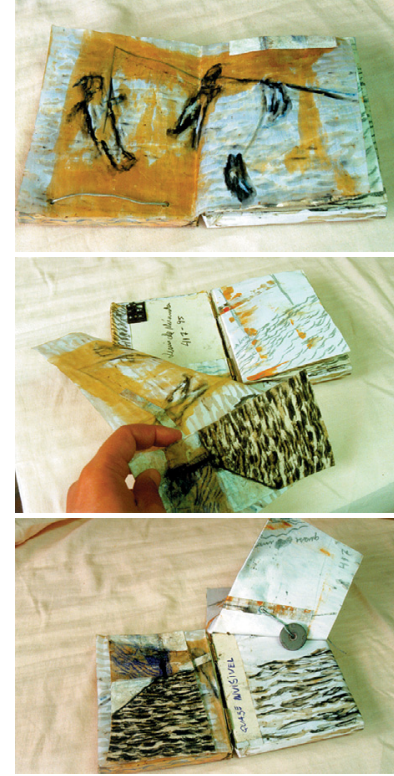

Lenir de Miranda, Livro para Beuys ver, 1993.
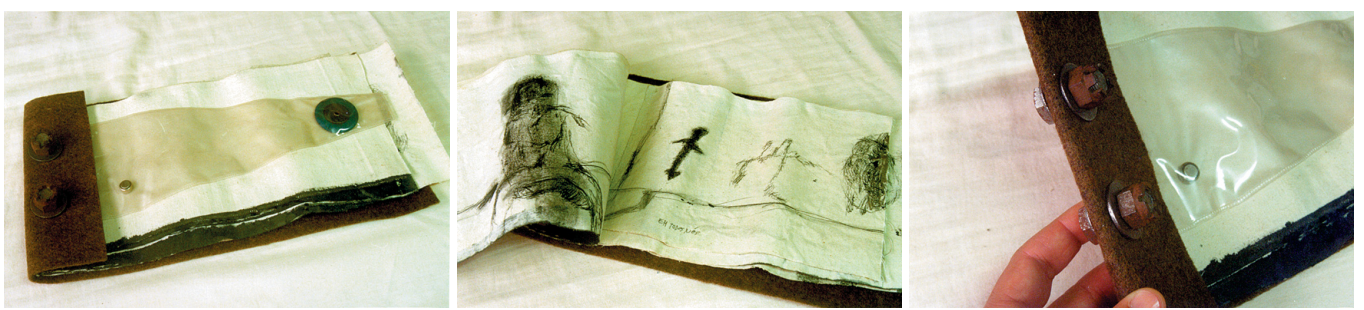
ver sem ser pintura. $\mathrm{O}$ objeto que temos nas mãos é apenas e nada mais do que um livro-objeto.

Lenir trabalha com duas linhas de aproximação ao livro. A primeira é o livro encontrado. A obra se constitui da intervenção sobre um livro tradicional. Achado em um sebo ou talvez entre suas coisas. As páginas são reaproveitadas como suporte para pinturas, desenhos ou grafismos, além da aposição de fios de cobre e pequenos objetos colhidos ao acaso ou com significação específica. É o caso do Livro com isoladores ou do Livro com funil de Buchner $e$ decantação. Nessa primeira linha, ela segue o que já é uma tradição no livro de artista, ao exemplo de Tom Phillips e de outros nomes, muitos deles jovens que, graças aos eventuais workshops de centros de encadernação artística, têm continuado a exercitar esse tipo de interferência. Lenir trabalha quase exclusivamente com peças únicas, nas quais o acréscimo à capa original de tecidos ou outros revestimentos, além de objetos do dia-a-dia, multiplica ou potencializa a ambiguidade inata ao livro. Ele continuará sendo ao mesmo tempo um suporte para texto e um objeto autônomo. Lenir respeita muito a expressão literária, que é uma parcela marcante no universo de seus afetos. Mas suas intervenções ao texto achado serão tridimensionais.

A segunda linha de sua produção é a predominante e talvez onde seja alcançado uma maior individualidade. É o caso do Livro induzido ou do Livro de um só - ligado. Em um grande número dessas obras é marcante a presença de sucata de eletricidade. Aqui os livros-objetos parecem alcançar uma expressividade mais pessoal, e que faz lembrar de novo o conceito de monstro (Calabrese, 1988, p.106). Para Icleia Cattani, o monstro poderia ser "talvez a mais violenta injúria ao humanismo" (Kern, Zielinsky e Cattani, 1995, p.175). Dá-se a espetacularidade pela demonstração ou exposição além da norma, pela desmesura para mais ou para menos, pelo ultrapassar dos limites e pela excedência física e espiritual. 
A agressividade, pelo aspecto plástico violento, da pintura anterior aos livros de Lenir de Miranda (período até 1985), juntamente com sua angústia, foi notada por Mônica Zielinsky: "A temática em Lenir não busca o agradável. Trata da realidade dramática e do seu posicionamento crítico frente a essa realidade. É sem dúvida uma arte de contestação" (Kern, Zielinsky e Cattani, 1995, p.87). Ela cita uma declaração da artista para um jornal da cidade: "Quando grupos de artistas plásticos maceram o corpo ou exibem a carne de animais mortos para chamar a atenção às crueldades burguesas, políticas ou outras, o que ocorre é a brutal vivência do mito da morte encarnado na arte" (p.81). Zielinsky ainda ressalta que Lenir usa na pintura a substituição de sua problemática pessoal pela problemática social: "Sufoco, contenção, proximidade ao mascaramento, por exemplo, são questões pessoais não resolvidas, portanto catarticamente estendidas na obra a uma questão contextual mais ampla" (p.92).

Os livros de Lenir são monstros, sim, mas são simultaneamente clássicos, além de, num certo sentido, metódicos. Eles abrem e fecham como se esperaria, embora não seja necessariamente nos sentidos ortogonais. Possuem dobras ocultas, bolsos, bolsas, pregas ou enxertos. Mas ainda que se desdobrem indefinidamente, se mantém algo da ideia de página, ou pela constituição
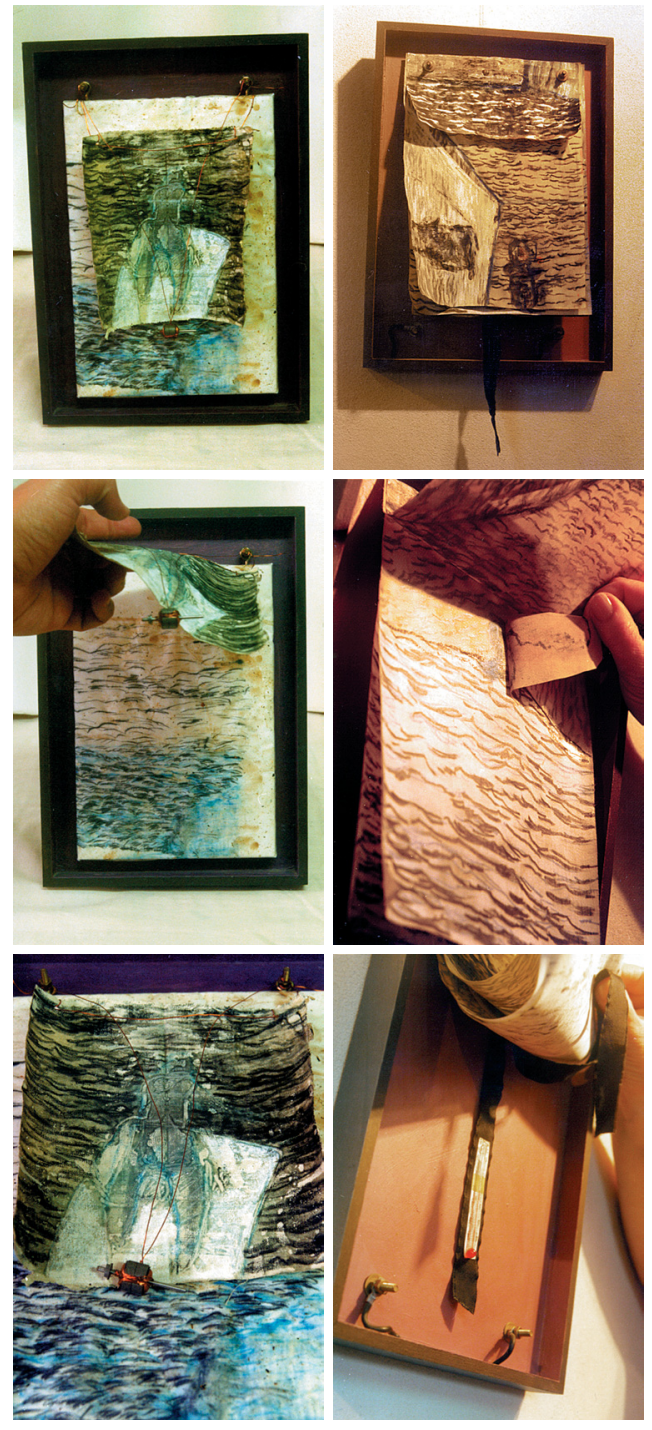

Lenir de Miranda, Éons de peregrinação, 1996.

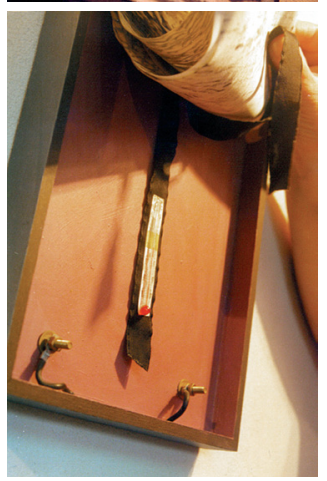

Lenir de Miranda, Suas reflexões em marés, 1996. característica, ou pelo comentário metafórico. A união dessas páginas é feita, como foi dito, através de elementos inusitados e contrastantes: dobradiças, arames, costura com fios elétricos, grandes ou minúsculos parafusos, presilhas ou que se puder imaginar. Nesse caso existe o comentário sobre a superfície que é única e do material que as une, o que reafirma a presença da matéria. Essa corporeidade personificadora faz com que a artista acabe por apelidar seus livros. Se aceitarmos que um título coisifica uma obra, então um apelido, que não deixa de ser um nome, a imagina um ser. Lenir acaba por nomear seus livros por apelidos, como o 
"livro irritante", pela presença barulhenta de uma chapa metálica, ou como o "livro macerado", pelo aspecto de decomposição ou degenerescência.

Dificilmente se pode imaginar esses livros de pé. Sua posição natural parece ser a horizontal, mesmo quando são de materiais rígidos. Isso talvez acentue a função da páginas não como sequência cinética, mas como etapas sedimentares. Estaria-se, assim, ao folheá-las, revelando tempos arqueológicos pagãos. Isso parece acontecer mesmo nos livros concebidos para serem pendurados na parede, um retorno do objeto de arte que se dá em espetáculo. Nesse caso, embora o folhear se dê num movimento de bloco (como um calendário de parede), parece ser mais acertado supor sua referência ao desvelamento por cortinas, o que é mais adequado a uma certa dramaticidade. Mas insisto, não cortinas de um templo, mas as cortinas das divisórias hospitalares. O segredo que elas escondem será uma surpresa humana.

Esse é, aliás, um dos primeiros binômios de qualquer livro: mostrar e esconder. Qualquer que seja o seu repertório, num maior ou menor grau ele estará coordenando a estrutura da obra. No caso presente, a dimensão do olhar é mais do que a de um simples leitor. O olhar é pleno. Lê, sim, às vezes. Mas no seu fluxo normal ele desvela. É de voyeur e de cientista. E necessário junto ao tato para esclarecer as relações físicas da estrutura da obra. Ou para ser enganado por armadilhas da composição e da cor. Em muitas obras encontramos num canto mais ou menos oculto os dizeres "quase visível”, eco do exercício de excitação sensorial que estamos desfrutando. Ou, num grau mais discreto, o uso de olhos mágicos, esses visores que possuímos em nossas portas para vermos sem sermos vistos. Eles são a própria redundância de ideias como segredo e secreto ou desvelamento e descoberta. Incrustados como cracas em outros objetos, ou mesmo numa página ou capa, tanto podem nos levar a usar a visão para a captação 
das mínimas marcas das superfícies, como podem conter outros elementos dentro de si: talvez o fragmento de uma planta, ou de um brinquedo. Um vestígio para o qual direcionamos nossa atenção instrumentalizada por um momento, sem que mais alguém possa ao mesmo tempo ver. Talvez vislumbremos aí a alma metafísica de seus livros.

Entre suas últimas obras, está Fim de expediente, 1998, um conjunto de doze livros. Desta vez eles tem texto impresso por computador, o que é uma exceção. Mas cada volume é individualizado. O texto é parcialmente obliterado com toda sorte de ações, o que faz da leitura um autêntico exercício muscular, uma ginástica para o olho. Eles têm muitas anexações de pequenos objetos, como dados, tíquetes de ônibus, arames, lixas, panos, espelhos, além do verso da última capa já portar a ficha de empréstimos para a biblioteca. As capas dos dois ou três primeiros foram feitas com liberdade por um encadernador seu amigo. Lenir não ficou satisfeita com o resultado, e o restante do grupo foi encadernado com cobertura marrom (tipo percalux), como livros de escriturários tradicionais. São mais acomodados do que seus trabalhos anteriores, talvez porque a elaboração do texto escrito, com a sua ordem inata, tenha drenado ou vampirizado um pouco do seu passionalismo.

No seu conjunto de obras parece existir uma esquize da intelecção. Expresso, talvez por um diálogo ético e psicológico que se movimenta pela propulsão da estética pictórica. A postura dual pode ser percebida pelo ferimento causado ao paradigma do códice, mas com o cuidado de não feri-lo de morte. Ele será mantido vivo, mesmo que como um zumbi. Esse ferimento é provocado não pelo assunto, que transita entre o universo
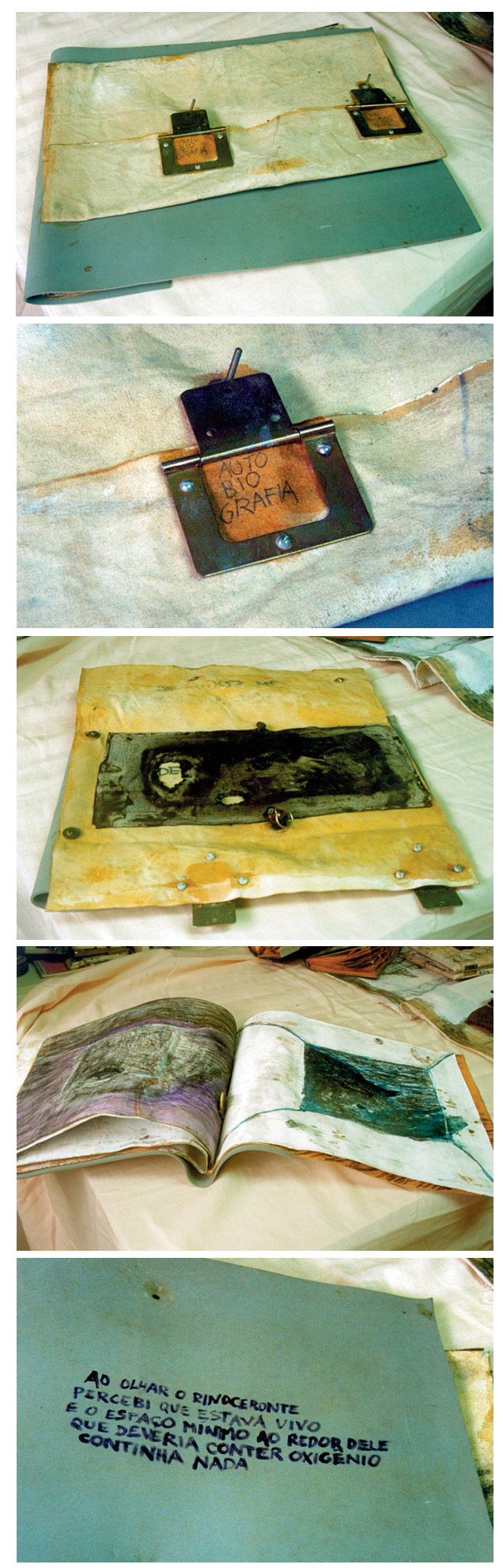

Lenir de Miranda, Livro com rinoceronte, 1994. 
pessoal e o autocomentário formal. O que fere a convenção da expectativa parece ser a contradição ou antagonismo interior à obra. Caso, por exemplo, da matéria quase crua, exposta em toda a sua corporeidade, confrontada com a sua versão industrializada, como anexo ou como prótese. A construção híbrida e múltipla, com ferragens e material elétrico - tão comuns ao universo masculino convencional -, e tecidos de todos os feitios - por sua vez comuns ao universo feminino -, sedimentam um jogo dos sentidos que move consigo os capítulos do mundo afetivo do sujeito. Tal mundo é tão denso quanto é tenso. Densidade que se dá pela insatisfação do espaço espiritual. E tensão percebida pela evidência da possibilidade de ser esse espaço espiritual um espaço labiríntico. A cumplicidade inevitável entre o homem e o livro seria uma armadilha? $\mathrm{E}$ ao que é da psique deve ser permitido o toque?

[...] a imaginação percorre constantemente um labirinto... algumas mensagens, cifradas, enveredam por esse labirinto, algumas vezes fiéis às regras do código, mas por fim, escolhem transgredir os caminhos e invertendo estruturas, ardilosamente triunfam como mensagens ambíguas, ao fim do labirinto. Então, por breve pausa, uma estranha imagem desprende-se do antigo labirinto e nos chama para um outro, desaparecendo após virarmos a cabeça em sua procura e deixando vestígios nos meandros das páginas seguintes. (Miranda, 1994, p.14)

Presas as mãos na armadilha, a variedade de caminhos e recintos propostos nas páginas devorarão nosso olhar como um minotauro ou uma esfinge o fariam. A tensão afetiva, o drama plástico, a arbitrariedade construtiva e, sobretudo, o uso espontâneo de uma vanguarda que já nem é mais tão vanguarda assim, com a fagia do suporte tradicional da lei e do conhecimento, fazem de Lenir um eco local para dúvidas e confrontos mais frequentes no outro hemisfério. Ela
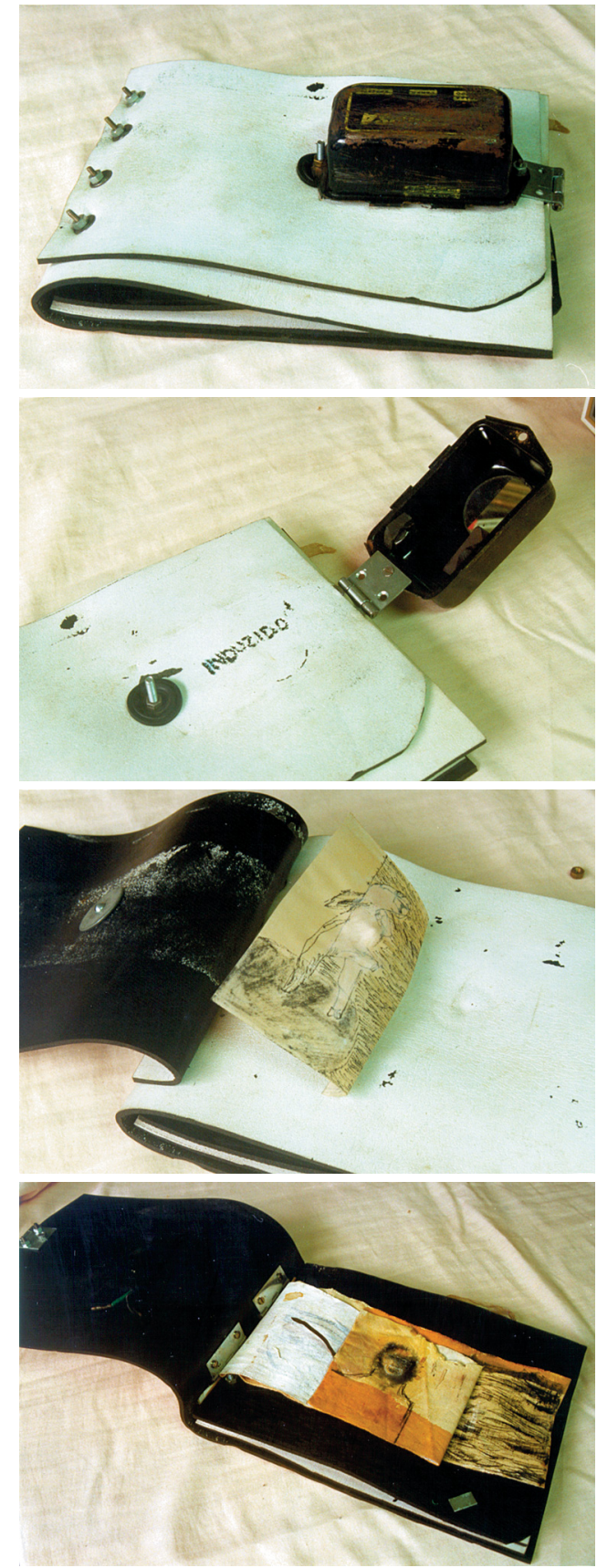

Lenir de Miranda, Livro induzido, 1994. 
sabe disso e sofre as consequências do convívio em um ambiente periférico aos maiores eventos do librismo. Especificamente no caso do mercado de objetos artísticos, persistem as categorias com sucesso em vendas: gravura, pintura, escultura e desenho, em qualquer ordem. Seus livros têm o privilégio de possuir uma estética diferenciada que perturba o conforto do olhar preguiçoso. Como todo fazedor de livros que não se pode ler, Lenir tem poucas vendas. Mas esse é um problema que merece certamente ser debatido, mas talvez em outro espaço. Que fique, por hora, registrada a sua mágoa.

Sobre o Livro bebendo água ela nos diz: "Existem nele várias marés para sugerir um corpo quase ao final do espaço e do tempo". O livro de Lenir de Miranda é um corpo e uma alma. É um sistema de dualismos: abrir e fechar, mostrar e esconder, ler e não ler, olhar e tocar, etc. (Esses dualismos são nossos conhecidos.) Uma dança dos materiais e das energias que por eles são geradas e que entre eles circula. Como no fecho do Livro induzido, onde, dentro da carcaça preta de um pequeno reator elétrico, um espelho seguro apenas por ímãs nos convoca para um resumo dos segredos da energia intelectual e da percepção.

Pode-se dizer que os livros de artistas pertencem a um mundo onde os corpos não morrem, pela absoluta impossibilidade de perderem suas almas. 